\author{
UNIVERSIDADE DE SÃo PAULO \\ FACULdADE DE FILOSOFIA, LETRAS E CIÊNCIAS HuMANAS \\ DEPARTAMENTO DE FILOSOFIA \\ Programa de Pós-GraduaçÃo em Filosofia
}

Edson Querubini

\title{
Escrita Instruída e Licença nos Ensaios de Montaigne
}

São Paulo

2015 


\section{Edson Querubini}

\section{Escrita Instruída e Licença nos Ensaios de Montaigne}

Tese apresentada ao Programa de Pós-Graduação em Filosofia, do Departamento de Filosofia da Faculdade de Filosofia, Letras e Ciências Humanas da Universidade de São Paulo, para obtenção do título de Doutor em Filosofia, sob a orientação do Prof. Dr. Sérgio Cardoso

São Paulo

2015 


\section{AgradeCIMENTOS}

Agradeço, muito especialmente, 0 acolhimento e a orientação criteriosa de Sérgio Cardoso.

Ao André Scoralick, pela conversas e pela ajuda.

A minha esposa Wanderleia. Ao Pedro, minha alegria. Aos meus pais. A minha querida irmã, Cris.

Aos Professores, Dr. Luis Antonio Alves Eva e Dr. Roberto Bolzani

Filho, pelas argüições e pelas observações que contribuíram muito para a continuidade deste estudo.

Aos funcionários da secretaria do Departamento de Filosofia pelo auxílio indispensável.

Ao CNPq, pelo apoio financeiro. 


\section{RESUMO}

QueRuBinI, E. D. Escrita instruída e Licença nos Ensaios de Montaigne. 2015. 226 f. Tese (Doutorado) - Faculdade de Filosofia, Letras e Ciências Humanas. Departamento de Filosofia, Universidade de São Paulo, São Paulo, 2015.

Procura-se nesse estudo ler os Ensaios de Montaigne, menos em sua dimensão de descrição verdadeira dos casos que são abordados e dos arrazoados que são produzidos, e mais em sua dimensão de produção de efeitos verossímeis e persuasivos; atentos, pois, à intenção de um escritor em "fazer crer" (fidem facere) mais que em dizer a "verdade". Assim, o propósito é o de relacionar o discurso deste autor com uma atividade plenamente ciente dos meios e instrumentos técnicos de produção da persuasão. Não se descarta a questão da veracidade do "autorretrato", mas, entende-se que esta consiste em um dos elementos fundamentais por cuja construção verossímil prima o esforço do Ensaísta. Busca-se, pois mostrar que o que o livro nos dá a ler são as múltiplas operações do espírito que integram a "maneira" de uma "persona" construída nos convencer de sua coincidência espontânea, veraz e bem sucedida com seu autor.

\section{Palavras-chave}

Montaigne; ensaio; escrita; exercício do julgamento; autorretrato; maneira; arte da persuasão. 


\section{ABSTRACT}

QUERUBINI, E. D. Learned Writing and License in Montaigne's Essays. 2015. 226 f. Doctoral Thesis - Faculdade de Filosofia, Letras e Ciências Humanas. Departamento de Filosofia, Universidade de São Paulo, São Paulo, 2015.

This thesis investigates Montaigne's Essays and the persuasive and verisimilar rhetorical effects that they manage to achieve, rather than consider them as true descriptions of the matters they discuss and the statements they entail. Thus, close attention is paid to Montaigne's intention to create belief (fidem facere) rather than to state the truth. Accordingly, this thesis sets out to identify this author's discourse as one that is fully aware of the technical instruments of rhetorical persuasion. Likewise, the veracity of the author's selfportrayal is not ignored, but it is understood as one of the fundamental elements at which the essayist's efforts to produce verisimilitude predominate. Therefore, this research intends to show that what one reads in Montaigne's Essays are the multiple operations of a mind that compose the "manner" of a persona that was built to persuade the reader that it coincides spontaneously, truthfully and successfully with the author.

\section{Keywords}

Montaigne; essay; writing; exercise of judgment; self-portrait; manner; art of persuasion. 


\section{SUMÁRIO}

Montaigne leitor e o leitor de Montaigne: à guisa de prefácio

Parte 1 - Interpretações sobre a natureza do ensaio .....................................26

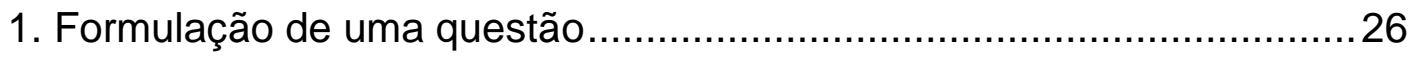

2. Matrizes do comentário contemporâneo (Villey, Friedrich, Tournon) .....41

a. Pierre Villey, o trajeto de constituição do 'ensaio' ...............................46

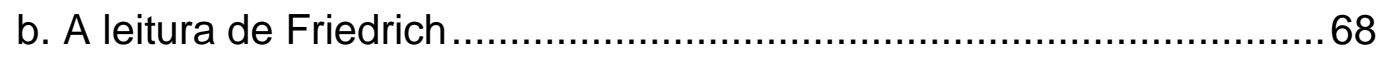

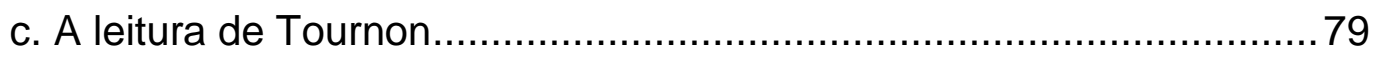

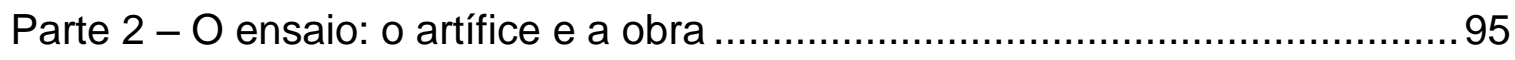

1. O artífice: a instituição do ensaísta .................................................... 95

a. A educação da suffisance ...........................................................102

b. A suffisance em exercício ..............................................................123

2. A obra: tópicas em torno da escrita do ensaio ....................................158

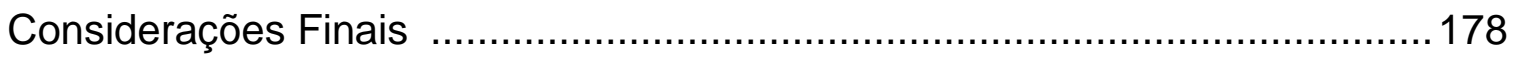

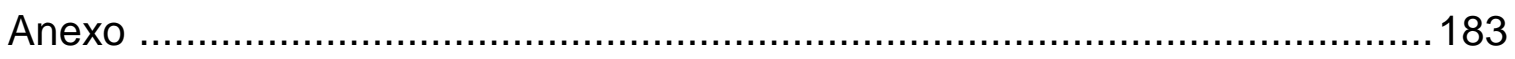

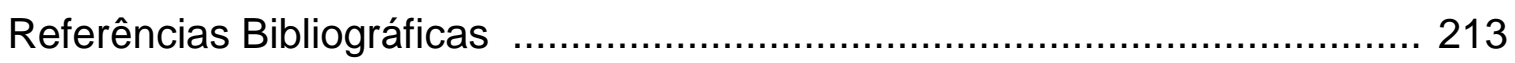




\section{Montaigne leitor e o leitor de Montaigne: à guisa de prefácio}

A caracterização do ensaio em Montaigne $^{1}$ não é simples. Talvez possamos apontar sua abertura para a busca e a inquirição como matriz de sua assistematicidade, de seu anti-dogmatismo, de seu caráter dialógico e de sua proliferação virtualmente infinita.

Facilmente se associam estes traços ao ceticismo confesso e a profissão de ignorância do autor. Ademais, as considerações e juízos inscritos na obra movem-se às mais das vezes no terreno já problemático ${ }^{2}$ das ações e da

\footnotetext{
${ }^{1}$ Utilizamos como fonte das citações dos Ensaios a edição Villey-Saulnier (Les Essais, Paris, PUF, Col. Quadrige, 1999), Como o francês montaigniano apresenta particularidades, para comodidade do leitor, incluímos a tradução brasileira feita por Rosemary Costek Abílio (Os Ensaios, São Paulo, Martins Fontes, 2000, 2001. 3.vol.), exceto em II, 1.b - "A educação da suffisance", em que as traduções são próprias. Nas referências aos Ensaios, o algarismo
} romano refere-se ao livro e o arábico, ao capítulo. As letras $[A]$, $[B]$ e $[C]$ no corpo do texto dos Ensaios indicam, respectivamente, as edições de 1580, 1588 e acréscimos posteriores do Exemplar de Bordeaux complementados pela edição de 1595 (póstuma). Embora as análises não tenham atentado para essas distinções de camadas, que indicam a cronologia de composição dos Ensaios, constitui tradição distingui-las.

${ }^{2}$ Montaigne compõe, a nosso ver, uma obra que, pensada da perspectiva do conhecimento, poderíamos qualificar de problemática. No seguinte sentido: não há enunciado expresso nos Ensaios que não possa ser revisto, e que o próprio autor por vezes não revê, exprimindo em lugares e momentos diferentes opiniões contrárias; não há proposição que mereça, por venerável que seja, outro estatuto que o de uma opinião a que outra opinião pode se contrapor e que acaba, apoiada em outras razões, por despersuadir da primeira. Em suma, a todo discurso se pode opor um discurso igual, o que concerne ao elemento central que define a qualidade do 
conduta humana, isto é, no terreno da contingência, constantemente assaltado pela mudança e pelas investidas caprichosas da Fortuna. Ora, é precisamente aí, neste domínio inconstante e mutável, que o discurso perde todo apoio para se fixar como discurso verdadeiro sobre as coisas. É precisamente aí que o ceticismo parece ter o horizonte mais favorável para triunfar e convidar o homem, e sua razão, a abandonar a presunção de saber e descansar tranquilamente em sua ignorância, livre também da pretensão de se inserir na ordem de um mundo, que se desconhece, com a pretensão de modificá-lo. E assim só resta a razão depor suas armas e abster-se tanto de querer conhecer, como de querer agir.

Esta leitura dos Ensaios não é falsa. Mas poderíamos dizer com MerleauPonty: "Tout cela ne vas pas loin". ${ }^{3}$ Esta associação tão comum muita vez desconsidera que o ceticismo, que opera uma espécie de redução de todas as proposições ao regime da mera opinião, é apenas um "solo" a partir do qual se desdobram as considerações do Ensaísta, seus "exercícios ou ensaios do julgamento". E que, independentemente da problematicidade e provisoriedade insuperáveis do discurso que se produz, é nele e através dele que Montaigne empreende conhecer-se e retratar-se. Ora, o auto-conhecimento e o retrato se fazem por meio de um, por assim dizer, diálogo propiciado, sobretudo, pelo

cético, sua dýnamis antithetiké: pois, do igual peso dos discursos e da "suspensão do juízo" que ela opera dependem esta redução de todo discurso ao âmbito do problema, ao domínio da opinião.

${ }^{3}$ Merleau-Ponty. Signes, "Lecture de Montaigne". Paris: Gallimard, 1960, p. 250. 
comércio e frequentação das almas do passado, aquelas que vivem somente na memória dos livros. Podemos dizer que os Ensaios nascem das experiências de leitura de seu autor, de uma "conversa" que, ao mesmo tempo, visa assimilar as "lições" das grandes almas do passado, bem como - de um modo, de fato, bem modesto em Montaigne - formar o discernimento e o julgamento e rivalizar com elas, levando adiante este diálogo crítico que alimenta de questões e de respostas, parciais, sua reflexão presente, sua experiência de si e do mundo tumultuado e turbulento que o rodeia. É assim que ele lê e discute os poetas, os historiadores, os filósofos, se não se colocando a mesma altura que eles, ao menos, continuando modesta e moderadamente as discussões que encontra neles.

Ora, esta volta ao passado, pela frequentação dos livros, porta um juízo em relação às produções daquelas almas inteiramente diverso do que se poderia esperar de uma postura estritamente cética. Pois esta nutre sua "suspensão de juízo", precisamente, da contradição que encontra e flagra entre as múltiplas doutrinas disponíveis, transformando o passado da Filosofia, dada a balbúrdia e confusão que nele se verifica, em uma história das tolas e inúteis produções do espírito humano, servindo apenas para alimentar a curiosidade dos homens e mais nada. Mas, só de rememorarmos os elogios esparsos e as defesas dos dois principais filósofos que alimentaram a reflexão montaigneana, Sêneca e Plutarco, e mesmo o elogio que, aqui e ali, se faz da Filosofia em geral, ficaríamos embaraçados e teríamos de nos questionar sobre esta oscilação do juízo acerca dela, já que, agora, ela passa a ser vista como uma 
história da sabedoria, como um passado preenchido das mais plenas realizações do saber, e da virtude que dele, de algum modo, emanaria. A filiação ao ceticismo nos leva a pensar no passado como história da loucura ou da tolice. Os elogios de suas principais fontes em Filosofia e das Letras em geral, no passado como história da sabedoria. Como conciliar estas duas visões?

A contradição, contudo, é somente aparente, e continua válido o elogio e o apego à ignorância confessados tão enfaticamente no livro, e é possível fazer conviverem os dois louvores sem muita dificuldade. Basta lembrar que o essencial das "lições" dos Ensaios pertence ao domínio do que neles aparece sob a rubrica da "maneira". Para ficar mais claro, que se recorra a um passo do capítulo sobre a "arte da conversação":

"L'agitation et la chasse est proprement de nostre gibier: nous ne sommes pas excusables de la conduire mal et impertinemment; de faillir à la prise, c'est autre chose. Car nous sommes nais à quester la verité; il appartient de la posseder à une plus grande puissance. Elle n'est pas, comme disoit Democritus, cachée dans les fons des abismes, mais plustost eslevée en hauteur infinie en la cognoissance divine. Le monde n'est qu'une escole d'inquisition. Ce n'est pas à qui mettra dedans, mais à qui faira les plus belles courses. Autant peut faire le sot celuy qui dict vray, que celuy qui dict faux: car nous sommes sur la maniere, non sur la matiere du dire."

[ $A$ agitação e a caçada são propriamente de nossa alçada; não temos desculpa por conduzi-la mal e tolamente; falhar na captura é outra coisa. Pois nascemos para buscar a verdade, possuí-la pertence a uma potência maior. Ela não está, como dizia Demócrito, escondida nos fundos dos 
abismos, mas sim elevada à altura infinita, no conhecimento divino. O mundo não é mais que uma escola de inquisição. Ganha não quem transpassar, mas sim quem fizer as corridas mais belas. Tanto pode fazer papel de tolo quem diz certo como quem diz errado; pois estamos na maneira, não na matéria do dizer.] (III, 8, p.928)

Este, talvez, seja um dos lugares em que mais claramente se assinala para o homem a tarefa de buscar a verdade sem jamais vir a possuí-la. Algo que facilmente assimilaríamos a tarefa conferida ao discípulo da escola pirrônica: ou seja, a continuação na investigação, a zétesis. Aliás, algo que assimilaríamos, igualmente, à venerável tradição da filosofia que remonta a Sócrates e tem seu início com ele: a afirmação de nada saber, acompanhada de uma revalorização da filosofia prática em detrimento das preocupações dos fisiólogos que o antecederam. Reconhecemos um certo ar de família ao sugerir esta última filiação e pensar nos Ensaios: neles também o registro das preocupações é eminentemente prático e se faz acompanhar de uma, como já dissemos, profissão de fé na ignorância e num exercício contínuo de crítica, sem contar o fato de que também neles se obedece a ordenação do preceito délfico: o texto é proposto como um auto-retrato, a tarefa ainda é a de conhecer-se a si mesmo. Mas, neste passo também encontramos, de certa forma, como que uma mudança ou deslocamento do regime das preocupações do Ensaísta, talvez marca de sua originalidade, na passagem do âmbito das matérias para o da 
"maneira". O que afeta o próprio estatuto do discurso que ele produz bem como sua maneira de ler:

"Et tous les jours m'amuse à lire en des autheurs, sans soin de leur science, y cherchant leur façon, non leur subject. Tout ainsi que je poursuy la communication de quelque esprit fameux, non pour qu'il m'enseigne, mais pour que je le cognoisse."

[E diariamente ocupo-me lendo os autores sem preocupar-me com seus conhecimentos, buscando seu modo, não seu assunto. Assim também busco a comunicação com algum espírito famoso, não para que ele me ensine, mas para que eu o conheça.] (id. ibid.)

Não há como deixar de ver que o plano da "maneira" assume uma importância e relevância muito acentuadas, quando a questão da verdade sobre as matérias fica afastada pela ausência de critérios que separem os discursos verdadeiros dos falsos. Se o lógos não se conforma às coisas, se sua relação com elas permanece problemática, a tarefa passa a ser a da conformação e ordenação interna do próprio lógos, ou melhor, do espírito que por meio do lógos efetua sua busca. É no exemplo de "ordem" e de "pertinência" dos espíritos que preferencialmente frequenta que Montaigne atenta mais, tanto lendo, como conversando.

E não só Montaigne lê assim, como nos convida igualmente a lê-lo neste plano da "maneira": 
“Je ne fay point de doute qu'il ne m'advienne souvent de parler de choses qui sont mieus traictées chez les maistres du mestier, et plus veritablement. C'est icy purement l'essay de mes facultez naturelles, et nullement des acquises [...] Qui sera en cherche de science, si la pesche où elle se loge: il n'est rien dequoy je face moins de profession. Ce sont icy mes fantasies, par lesquelles je ne tasche point à donner à connoistre les choses, mais moy: elles me seront à l'adventure connuez un jour, ou l'ont autresfois esté, selon que la fortune m'a peu porter sur les lieux où elles estoient esclaircies. [...] Ainsi je ne pleuvy aucune certitude, si ce n'est de faire connoistre jusques à quel poinct monte, pour cette heure, la connoissance que j'en ay. Qu'on ne s'attende pas aux matieres, mais à la façon que j'y donne."

[Não tenho dúvida de que amiúde me advém falar de coisas que são mais bem tratadas nos mestres do ofício, e mais verdadeiramente. Está aqui puramente o ensaio de minhas faculdades naturais, e não das adquiridas [...]. Quem estiver em busca de conhecimento que o pesque onde ele se aloja: não há nada que eu professe menos. Estão aqui minhas fantasias, com as quais não procuro dar a conhecer as coisas e sim a mim mesmo: talvez um dia elas venham a ser conhecidas por mim, ou o tenham sido outrora, conforme o acaso me possa ter levado aos locais onde eram esclarecidas. [...] Assim, não dou garantia de certeza alguma, a não ser de revelar até que ponto chega, neste momento, o conhecimento que tenho delas. Não se dê atenção às matérias e sim à maneira como as apresento.] (II, 10, p. 407-408) 
Assim, vemos que o sentido a atribuir às lições dos "autores" ou de "algum espírito famoso" não é mais o que usualmente se espera. Da mesma forma, o que devemos buscar como lição nos Ensaios. Lição aqui não é mais de fundo, o que se coaduna com a permanência na investigação, mas de forma ("modo", em francês façon), o que não trai a liberdade e a autonomia de quem ordena submeter tudo ao crivo e nada aceitar por simples autoridade e confiança, tal como testemunha um passo do "Da educação das crianças", que dispõe sobre a tarefa do preceptor na educação da criança:

"Qu'il luy face tout passer par l'estamine et ne loge rien en sa teste par simple authorité et à credit; les principes d'Aristote ne luy soyent principes, non plus que ceux des Stoiciens ou Epicuriens. Qu'on luy propose cette diversité de jugemens: il choisira s'il peut, sinon il en demeurera en doubte."

[Que ele [preceptor] o faça passar tudo pelo crivo e nada aloje em sua cabeça por simples autoridade e confiança; que os princípios de Aristóteles não Ihe sejam princípios, não mais que os dos estóicos e epicuristas. Que Ihe proponham essa diversidade de opiniões; ele escolherá se puder; se não permanecerá em dúvida.] (I, 26, p. 151)

Colhemos este texto no curso de um arrazoado que distingue e opõe claramente duas concepções de educação e de relação com o saber tradicional: uma, que se critica e que tem por base a lição de autoridade a ser acatada, memorizada e simplesmente repetida; outra, que se promove e que visa formar o "entendimento e os costumes" da criança, fazer "antes uma cabeça bem feita 
do que bem cheia", forjar uma capacidade de julgar e discernir em cada situação o que convém pensar, como convém agir. O que se exprime nestas páginas a que aludimos, é sim uma crítica acerba aos ensinamentos da autoridade e da memória. E é em nome de um "vigor e liberdade" da alma que é instruída que esta queixa se faz:

"Nostre ame ne branle qu'à credit, liée et contrainte à l'appetit des fantasies d'autruy, serve et captivée soubs l'authorité de leur leçon. On nous a tant assubjectis aux cordes que nous n'avons plus de franches allures. Nostre vigueur et liberté est esteinte."

[Nossa alma só se move por crédito, ligada e constrangida ao apetite das fantasias de outros, serva e cativa sob a autoridade do ensinamento destes. Tanto nos submeteram às cordas que já não temos livres os passos. Nosso vigor e nossa liberdade estão extintos.] (id. ibid.)

E em lugar desta educação que só faz "criailler à nos oreilles, comme qui [verse] dans un antonnoir" [Martelar em nossos ouvidos, como quem despe[ja] em um funil, o que se prescreve é que se coloque a alma do discípulo "sur la montre, luy faisant gouster les choses, les choisir et discerner d'elle mesme" [ $\mathrm{Na}$ parada, fazendo-a experimentar as coisas, escolhê-las e discernir por si mesma] (id. ibid.), a fim de que ela verdadeiramente digira e torne seu o que acabou de aprender: "Que ce qu'il viendra d'apprendre, il le lui face mettre en cent visages et accommoder à autant de divers subjets, pour voir s'il l'a encore bien pris et bien faict sien" [Aquilo que tiver acabado de ensinar, faça a criança colocá-lo em 
cem facetas e adaptar a tantos outros diversos assuntos, para ver se ela realmente o captou e incorporou] (id. ibid., p. 151). E, mais adiante, acrescenta, retomando uma famosa metáfora presente em Cícero:

"Les abeilles pillotent deçà delà les fleurs, mais elles en font apres le miel, qui est tout leur; ce n'est plus thin ny marjolaine: ainsi les pieces empruntées d'autruy, il les transformera et confondera, pour en faire un ouvrage tout sien: à sçavoir son jugement. Son institution, son travail et estude ne vise qu'à le former."

[As abelhas sugam das flores aqui e ali, mas depois fazem o mel, que é todo delas: já não é tomilho nem manjerona. Assim também as peças emprestadas de outrem ele irá transformar e misturar, para construir uma obra toda sua: ou seja, seu julgamento. Sua educação, seu trabalho e estudo visam tão-somente a formá-lo.] (id., p. 152)

Neste programa não podemos dizer que não haja nenhuma intenção de conservar, ao menos parcialmente, o conjunto das lições que nos foram legadas pela memória dos livros do passado. Que não haveria neles nada que devesse ser acolhido como verdade válida, excetuando, claro, doutrinas a serem simplesmente aceitas como prontas e acabadas, como conjunto de dogmas incontestáveis. Aí não parece haver simplesmente uma desqualificação radical de todo saber constituído pelo passado e transmitido ao presente, feita em nome de uma relação direta e mais pura com as coisas, livre dos juízos e opiniões que sobre elas se acumularam no tempo. Seria engano pensar que não é deste 
passado que o pensamento de Montaigne ganha seu impulso e forma, no movimento sinuoso de cada um de seus ensaios. Com efeito, a obra de pensamento que temos em mãos - assim pensamos - não pode ser entendida como um constante exercício de confrontação de doutrinas opostas com vistas à reposição do estado de "suspensão do juízo", visando a consequente tranquilidade que daí decorre. Ela não se alimenta do passado apenas para esvaziá-lo de toda pretensão de verdade, embora esta seja uma de suas vertentes. O motivo profundo deste pensamento se encontra, a nosso ver, alhures, num lugar em que as lições do passado retomam seu interesse e seu valor. Em seu conjunto o que se dá é um deslocamento do interesse pela verdade dessas opiniões, em prol do modo como elas se prestam a alimentar sua própria reflexão e interrogação, seu modo de fazer filosofia. Para tentar aprofundar nossa compreensão desse deslocamento e essa maneira de fazer filosofia, vejamos um outro momento do mesmo passo do "Da educação das crianças":

"Car s'il embrasse les opinions de Xenophon et de Platon par son propre discours, ce ne seront plus les leurs, ce seront les siennes. Qui suit un autre, il ne suit rien. II ne trouve rien, voire il ne cerche rien. [...] II faut qu'il emboive leurs humeurs, non qu'il aprenne leurs preceptes. Et qu'il oublie hardiment, s'il veut, d'où il les tient, mais qu'il se les sçache approprier. La verité et la raison sont communes à un chacun, et ne sont non plus à qui les a dites premierement, qu'à qui les dict apres. Ce n'est non plus selon Platon que selon moy, puis que luy et moi l'entendons et voyons de mesme." 
[Pois se ele [o discípulo] abraçar as opiniões de Xenofonte e de Platão por seu próprio julgamento, não serão mais as opiniões deles, serão as suas. Quem segue um outro nada segue. Nada encontra, e até mesmo nada procura. [...] É preciso que se impregne dos humores deles, não que aprenda seus preceitos. E que, se quiser, esqueça imediatamente de onde os obtém, mas que saiba assimilá-los. A verdade e a razão são comuns a todos, e não pertencem a quem as disse primeiramente mais do que a quem as diz depois. Não é segundo Platão mais do que segundo eu mesmo, já que ele e eu o entendemos e vemos da mesma forma.] (id., p. 151-152)

É à ideia de assimilação presente aqui que devemos atentar. É ela que permite ao Ensaísta referir uma "verdade" e uma "razão" comum a todos, subtraindo-se ao mesmo tempo ao jugo da autoridade daquele que primeiro a proferiu. Mas não nos enganemos com o sentido desta verdade, dando a palavra um peso epistemológico que ela não tem. Isto porque ela nos remete ao domínio do que realmente interessa a Montaigne: a "ética". As lições de filosofia que serão ministradas ao discípulo dizem respeito antes de tudo a formação do julgamento e aos "hábitos e costumes" de virtude que devem ser desenvolvidos nele através de preceitos que não basta saber de cor e repetir, mas é necessário levar a efeito: "Le guain de nostre estude, c'est en estre devenu meilleur et plus sage" [O proveito de nossos estudos está em com ele nos termos tornado melhores e mais sensatos] (id., p. 152). E, um pouco antes, falando de como o preceptor deve avaliar o aprendizado: "Qu'il ne luy demande pas seulement compte des mots de sa leçon, mais du sens et de la substance, et qu'il juge du 
profit qu'il aura fait, non par le tesmoignage de sa memoire, mais de sa vie" [Que ele Ihe peça contas não apenas das palavras de sua lição mas sim do sentido e da substância, e que julgue sobre o benefício que tiver feito não pelo testemunho de sua memória e sim pelo de sua vida] (id., p. 151). Logo, as lições dizem respeito, acima de tudo, a uma "maneira" de discernir, a uma "capacidade" de julgar e agir, tomadas dos exemplos das obras do passado, assimiladas e apropriadas por aquele que efetivamente as compreendeu e, portanto, tornou-se capaz de não só sabê-las, mas aplicá-las e agir em conformidade com elas. Esta tópica da assimilação, no que concerne ao exercício do julgamento e às ações, é que leva Montaigne a criticar tão acidamente o pedantismo e a erudição puramente livresca, e a fazer das "ciências" apenas um ornamento e acessório das almas bem formadas, das "cabeças bem feitas". Não é outro o critério que aplica para discernir a excelência e verdadeira "capacidade" (suffisance) dos espíritos em se "Da arte da conversação". Lá também a apropriação das lições, sobretudo de "maneira", das grandes almas, serve para separar os aptos dos ineptos ou tolos.

Por isso mesmo, a história, isto é, o gênero historiográfico, tal como o praticam um Tácito ou um Plutarco, tem tanta preeminência no pensamento do filósofo bordelês. É na exemplaridade das vidas que eles narram, e no próprio exercício do julgamento que exercem em seus escritos que Montaigne vê o cerne da Filosofia. Do mesmo modo, poderíamos dizer que não nos convida a outra coisa senão a ler seus "costumes e hábitos", seus modos de julgar, quando se retrata em seu livro. Convite que se estende ao de uma imitação de 
sua "maneira" de ensaiar o julgamento, e não a uma obediência a seus preceitos. Aliás, nada mais distante da intenção de Montaigne do que propor-se como preceptor, ele que se valoriza apenas pelo fato de que é capaz de exercer com isenção de afeto o julgamento sobre si mesmo e conhecer-se. 0 testemunho mais eloquente de que o essencial do ensaio encontra-se no exercício do julgamento, Montaigne nos fornece no prólogo do capítulo "De Demócrito e Heráclito". Vale citar, apesar de longo o trecho, pois nele se reúne e condensa muito do vimos sugerindo:

"Le jugement est un util à tous subjects, et se mesle par tout. A cette cause, aux essais que j'en fay ici, j'y employe toute sorte d'occasion. Si c'est un subject que je n'entende point, à cela mesme je l'essaye, sondant le gué de bien loing; et puis, le trouvant trop profond pour ma taille, je me tiens à la rive: et cette reconnoissance de ne pouvoir passer outre, c'est un traict de son effect, voire de ceux dequoy il se vante le plus. Tantost, à un subject vain et de neant, j'essaye voir s'il trouvera dequoy lui donner corps, et dequoy l'appuyer et estançonner. Tantost je le promene à un subject noble et tracassé, auquel il n'a rien à trouver de soy, le chemin en estant si frayé qu'il ne peut marcher que sur la piste d'autruy. Là il fait son jeu à eslire la route qui luy semble la meilleure, et, de mille sentiers, il dict que cettuy-cy, ou celuy là, a esté le mieux choisi. Je prends de la fortune le premier argument. Ils me sont également bons. Et ne desseigne jamais de les produire entiers. Car je ne voy le tout de rien: Ne font pas, ceux qui promettent de nous le faire veoir. De cent membres et visages qu'a chaque chose, j'en prens un tantost à lecher seulement, tantost à effleurer; et par fois à pincer jusqu'à l'os. J'y donne une poincte, non pas le plus largement, mais le plus profondement 
que je sçay. Et aime plus souvent à les saisir par quelque lustre inusité. Je me hazarderoy de traitter à fons quelque matière, si je me connoissoy moins. Semant icy un mot, icy un autre, eschantillons despris de leur piece, escartez, sans dessein et sans promesse, je ne suis pas tenu d'en faire bon, ny de m'y tenir moy mesme, sans varier quand il me plaist; et me rendre au doubte et incertitude, et à ma maistresse forme, qui est l'ignorance. Tout mouvement nous descouvre."

[O julgamento é um instrumento para todos os assuntos, e se imiscui por toda parte. Por causa disso, nos ensaios que faço aqui, emprego nisso todo tipo de oportunidade. Se é um assunto de que nada entendo, por isso mesmo ensaio-o, sondando o vau de bem longe; e depois, achando-o fundo demais para minha estatura, mantenho-me na margem; este reconhecimento de não poder passar para o outro lado é uma característica de sua ação, e mesmo das que mais o envaidecem. Por vezes, em um assunto vão e sem valor, procuro ver se ele encontrará com que lhe dar corpo, e com que o apoiar e escorar. Por vezes passeio-o por um assunto nobre e repisado, no qual nada tem a descobrir por si, estando o caminho tão trilhado que ele só pode caminhar sobre as pegadas de outrem. Então atua escolhendo o caminho que Ihe parece o melhor e, entre mil veredas, diz que esta, ou aquela, foi a mais bem escolhida. Tomo da fortuna o primeiro argumento. Eles me são igualmente bons. Mas nunca me proponho apresentá-los inteiros. Pois não vejo o todo de coisa alguma; tampouco o vêem os que nos prometem mostrá-lo. De cem membros e rostos que cada coisa tem, tomo um, ora para somente roçá-lo, ora para examinar-lhe a superfície; e às vezes para pinçá-lo até o osso. Faço-Ihe um furo, não o mais largo porém o mais 
fundo que sei. E quase sempre gosto de captá-los por algum ângulo inusitado. Arriscar-me-ia a tratar a fundo alguma matéria, se me conhecesse menos. Semeando aqui uma palavra, ali uma outra, retalhos tirados de sua peça, separados, sem intenção e sem compromisso, não estou obrigado a fazê-lo bem nem a limitar a mim mesmo, sem variar quando me aprouver; e render-me à dúvida e incerteza, e à minha forma mestra, que é a ignorância. Todo e qualquer movimento nos revela.] (I, 50, p. 301-302)

A par desta ideia de assimilação das "lições" das grandes almas do passado que visa formar o julgamento e o discernimento, os quais, por sua vez, Montaigne empenha e emprega na confecção de seu livro, devemos ainda lembrar que os ensaios são como "conversas". Conversa que ele vai entretendo com seus autores, como leitor, e no curso da qual vai tecendo o seu próprio livro, feito, aliás, em diversas etapas em que ele mesmo se relê e, reagindo ao que antes registrara, faz múltiplos acréscimos. Conversa que ele mantém conosco, seus leitores, convidando-nos a observar antes os andamentos de seu juízo que as verdades das matérias. As alusões a isto estão espalhadas por todos os três livros dos Ensaios: "Je parle au papier comme je parle au premier que je reencontre" [Falo ao papel como ao primeiro que encontro] (III, 1, p. 790). Poderíamos multiplicar as referências. Seguramente o testemunho maior desta afinidade estrutural com a conversa é o capítulo dedicado a "arte da conversação". Ali encontramos o elogio mais elevado de seu fruto e prazer:

"Le plus fructueux et naturel exercice de nostre esprit, c'est à mon gré la conference. J'en trouve l'usage plus doux que d'aucune autre action de 
nostre vie [...] L'estude des livres, c'est un mouvement languissant et foible qui n'eschauffe poinct: là où la conference apprend et exerce en un coup. Si je confere avec une ame forte et un roide jousteur, il me presse les flancs, me pique à gauche et à dextre, ses imaginations eslancent les miennes. La jalousie, la gloire, la contention me poussent et rehaussent au dessus de moy-mesmes. Et l'unisson est qualité du tout ennuyeuse en la conference."

[O mais proveitoso e natural exercício de nosso espírito é, em minha opinião, a conversação. Acho sua prática mais doce do que qualquer outra ação de nossa vida; [...] O estudo dos livros é um movimento lânguido e fraco que não aquece, ao passo que a conversação ensina e exercita de um só golpe. Se converso com uma alma forte e um lutador rijo, ele me assalta os flancos, espicaça-me à esquerda e à direita, suas idéias acirram as minhas. A rivalidade, a ambição, a contenda impulsionam-me e me alçam acima de mim mesmo. E a unanimidade é uma característica totalmente tediosa na conversação.] (III, 8, p. 922-923)

Apenas dois reparos. Primeiro, que não nos engane este aparente desprezo pelos livros que desponta aqui. É bastante trazer a memória o fato de que este mesmo capítulo se encerra com uma leitura e exercício do julgamento, que é ao mesmo tempo uma conversa com Tácito. Exemplo claro de que Montaigne lê como quem conversa, de que a conversa é modelo para sua postura diante dos textos que frequenta. Depois, sobre o espírito de contenda e contradição que move o exercício da conversação - e o próprio pensamento - e faz o espírito avançar, ir adiante, "alçar-se acima de si mesmo", instruindo-se e 
exercitando-se. Espírito que só é generoso e está vivo, se não descansa e se mantém em movimento, sempre em busca, como nos lembra igualmente o " $\mathrm{Da}$ experiência":

"Ce n'est rien que foiblesse particuliere qui nous faict contenter de ce que d'autres ou que nous-mesmes avons trouvé en cette chasse de cognoissance; un plus habile ne s'en contentera pas. II y a tousjours place pour un suyvant, ouy et pour nous mesmes, et route par ailleurs. II n'y a point de fin en nos inquisitions; nostre fin est en l'autre monde. C'est signe de racourciment d'esprit quand il se contente, ou de lasseté. Nul esprit genereux ne s'arreste en soy: il pretend tousjours et va outre ses forces; il a des eslans au delà de ses effects; s'il ne s'avance et ne se presse et ne s'accule et ne se choque, il n'est vif qu'à demy; ses poursuites sont sans terme, et sans forme; son aliment c'est admiration, chasse, ambiguité."

[É apenas a fraqueza pessoal que nos faz contentarmo-nos com o que outros ou nós mesmos houvermos encontrado nessa caça ao conhecimento; alguém mais inteligente não se contentará. Há sempre lugar para um seguinte, certamente até mesmo para nós, e caminhos alhures. Não há fim em nossas investigações; nosso fim está no outro mundo. É sinal de estreiteza de espírito quando ele se contenta, ou de lassidão. Nenhum espírito generoso detém-se em si mesmo: sempre tende para frente e vai além de suas forças; tem impulsos que excedem suas realizações; se não avançar e não se apressar e não recuar e não se bater só estará vivo pela metade; suas diligências não têm termo nem forma; seu alimento é espanto, caçada, ambiguidade.] (III, 13, p. 1068) 
Por aí se vê como o "inacabamento" e a "abertura", próprios do espírito que conversa e, por meio do diálogo, investiga e busca, inscrevem-se no cerne da própria atividade do Ensaísta. Desta "abertura", que tem por consequência a proliferação virtual dos Ensaios, o horizonte de uma reflexão que nunca pára e é sempre retomada, gostaria de aduzir, como exemplo e para encerrar, ainda dois passos:

"Et combien y ay-je espandu d'histoires qui ne disent mot, lesquelles qui voudra esplucher un peu ingenieusement, en produira infinis Essais. Ny elles, ny mes allegations ne servent pas toujours simplement d'exemple, d'authorité ou d'ornement. Je ne les regarde pas seulement par l'usage que j'en tire. Elles portent souvent, hors de mon propos, la semence d'une matiere plus riche et plus hardie, et sonnent à gauche un ton plus delicat, et pour moy qui n'en veux exprimer d'avantage, et pour ceux qui rencontreront mon air."

[E quantas histórias divulguei que não dizem uma palavra [a que não acrescentei comentário algum], com as quais quem quiser esmiuçá-las um tanto engenhosamente produzirá infinitos Ensaios. Nem elas, nem minhas citações servem sempre simplesmente de exemplo, de autoridade e de ornamento. Não as encaro somente pelo proveito que tiro delas. Amiúde trazem consigo, fora de meu assunto, a semente de uma matéria mais rica e mais ousada, e soam de través um tom mais refinado, tanto para mim que não quero expressar mais como para aqueles que coincidirem com meu ar [maneira de ser ou pensar].] (I, 40, p. 251)

E, 
"Il y a dans Plutarque beaucoup de discours estandus, tres-dignes d'estre sceus, car à mon gré c'est le maistre ouvrier de telle besongne; mais il y en a mille qu'il n'a que touché simplement: il guigne seulement du doigt par où nous irons, s'il nous plaist, et se contente quelquefois de ne donner qu'une attainte dans le plus vif d'un propos. II les faut arracher de là et mettre en place marchande. Comme ce sien mot, que les habitans d'Asie servoient à un seul, pour ne sçavoir prononcer une seule sillabe, qui est Non, donna peut estre la matiere et l'occasion à la Boitie de sa Servitude Volontaire."

[Há em Plutarco muitas reflexões extensas, muito dignas de serem conhecidas, pois em minha opinião ele é o mestre-de-obras de tal atividade [Montaigne está se referindo à História]; mas há mil outras que ele simplesmente tocou: somente aponta com o dedo por onde devemos ir, se nos aprouver, e às vezes se limita a dar uma estocada no ponto mais sensível de um assunto. É preciso arrancá-los de lá e colocá-lo à mostra. Como aquela sua afirmação de que os habitantes da Ásia eram escravos de um único senhor por não saberem pronunciar uma simples sílaba, que é Não, talvez tenha dado a La Boétie a matéria e a ocasião para sua Servidão Voluntária.] (I, 26, p. 156)

Não há duvidar, diante de um texto como este, que estamos lidando com uma forma de fazer filosofia que se antecipa na resposta a problemas que são os do nosso tempo e da nossa maneira de fazer filosofia. Tempo que nos impõe o trânsito pela História da Filosofia para fazer Filosofia, e que parecia nos obrigar a irrelevância de fazer somente a "história erudita do passado", sem 
interesse para a Filosofia. Pois, é impossível não pensar, nestas alusões a "ensaios que suscitam ensaios", no impensado em Merleau-Ponty, naquilo que uma Filosofia ao pensar, deixa para ser pensado por outros, no pensamento que dá a pensar em seu excesso de significação, no transbordamento da obra.

Com este recorte e esta costura breve de alguns textos dos Ensaios, talvez tenhamos podido vislumbrar um pouco o sentido positivo que o passado da filosofia pode ter para Montaigne.

Mas, isto quanto aos traços próprios do ensaio e a maneira como Montaigne lê os outros e a si mesmo. Diante desses traços, como nos orientarmos para ler, nós mesmos, esta obra? Pois resta tratar, brevemente, do sentido de nossa "conversa com Montaigne", fazendo algumas distinções necessárias e tentando assimilar o essencial de suas lições de "maneira". Acredito que estes poucos elementos que recortamos, contudo, ajudem-nos a estabelecer alguns critérios para a leitura e, quem sabe, estabelecer para o estudo da história, e respeitando seu rigor, ao menos um horizonte mais arejado e amplo, que não seja somente o da "história erudita do passado" e ponto. Algo como um convite à retomada da interrogação, aprendendo seu exercício nesta "conversa", em que, de início, precipuamente nos fazemos ouvintes atentos. 
É evidente que há uma diferença entre nós, que estudamos um clássico como historiadores, já imbuídos dos pudores de filólogo aplicado, e Montaigne, que retoma, imita por vezes, pilha, rivaliza, dialoga polemicamente com os autores do passado, interrogando seu tempo com categorias e formas de pensar que deles aprendeu, ou que, a partir dos ensinamentos deles, forjou para si. Evidentemente, Montaigne lê seus autores como um igual, paradoxalmente como um amigo e ao mesmo tempo rival, pois sabe que sem a contradição o pensamento acaba por se fixar, mas que sem a benevolência que vige entre amigos e o horizonte comum da verdade sempre de novo buscada que compartilham ele pode se perder. ${ }^{4}$ Nós, não.

Mas não poderia ser senão nas duas ideias principais que procuramos destacar acima - quais sejam, a de assimilação e formação do discernimento através de uma conversa com o passado, tal como aparecem no pensamento de Montaigne - que nos apoiaríamos logo de saída. Algo a que Jean Maugüé já acenava em 1935 como membro da missão francesa na então recém criada Universidade de São Paulo. A primeira tarefa que se nos impõe, aliás, assinalada pelo próprio autor, é a de escuta e compreensão profunda de suas múltiplas variações e suas "galhardas escapadelas", dos movimentos de seus "exercícios do juízo", nem sempre fáceis de acompanhar, como nos adverte, mais uma vez encontrando em Plutarco uma fonte e uma inspiração:

\footnotetext{
${ }^{4}$ Esta é uma das tantas lições que aprendemos, mais uma vez, com a leitura do "Da arte da conversação", mas nas quais não cabe entrar aqui.
} 
"Il est des ouvrages en Plutarque où il oublie son theme, où le propos de son argument ne se trouve que par incident, tout estouffé en matiere estrangere: voyez ses alleures au Daemon de Socrates. O Dieu, que ces gaillardes escapades, que cette variation a de beauté, et plus lors que plus elle retire au nonchalant et fortuite. C'est l'indiligent lecteur qui pert mon subject, non pas moy; il s'en trouvera tousjours en un coing quelque mot qui ne laisse pas d'estre bastant, quoy qu'il soit serré. Je vois au change, indiscrettement et tumultuairement."

[Há em Plutarco obras em que ele esquece seu tema, em que o assunto de seu discurso só é encontrado incidentalmente, sufocado em meio à matéria alheia a ele: vede suas idas e vindas no Demônio de Sócrates. Oh, Deus, como essas galhardas escapadelas, como essa variação tem beleza, e tanto mais quanto mais parecer descuidosa e casual! É o leitor indiligente que perde meu assunto, não sou eu; sempre se encontrará num cantinho alguma palavra que não deixe de ser suficiente, embora seja concisa. Vou em busca da variedade, de forma desmedida e tumultuosa.] (III, 9, p. 994)

Nesta tarefa de escuta e compreensão diligente, somos compelidos a tentar acompanhar e refazer seus movimentos, seguindo o fio ondulante do pensamento de Montaigne em cada ensaio - fio cujo nexo, às vezes tão frágil, que liga os múltiplos membros do arrazoado, recebe a modesta designação de "à propos" - atentando para aquilo mesmo a que ele nos avisa que é o essencial: a sua "maneira". Somente aí somos capazes de ver o que os Ensaios querem nos mostrar: o exercício, em ato, do pensamento que opera seletiva e 
criteriosamente na escolha dos caminhos que irá trilhar, sem antecipar e premeditar, porém, seus fins e objetivos. Afinal o que importa, neste passeio, não é atingir o alvo, mas "fazer as mais belas corridas". De nossa parte, resta a esperança de aprender a fazer, com pertinência e conveniência difíceis de conquistar, outras corridas que, no mínimo, captem uma centelha da pertinência de um Clássico e acenem - como diz Montaigne de seus escritos em relação aos do passado -, de longe para ela, dizendo sim. 


\section{PARTE I: INTERPRETAÇõES SOBRE A NATUREZA DO ENSAIO}

\section{Formulação de uma questão}

Que Os Ensaios não são uma obra benevolente e dócil com a tradição do pensamento herdado da antiguidade parece bem estabelecido por pouco mais de um século de estudos acadêmicos. As interpretações que mais frequentemente se tem apresentado da obra relacionam-na intimamente com a escola do ceticismo e, portanto, com uma profunda e radical crítica do saber instituído pelas escolas de filosofia consideradas dogmáticas. Mais do que uma crítica do saber como produto das operações da razão, são as próprias vias de acesso ao conhecimento possuídas pelo homem, os instrumentos mesmos, ou seja, a razão e a experiência, que parecem ser colocados em jogo e risco pelo acerba invectiva contra os excessos da presunção humana presente nas páginas desse livro único e, sobretudo, nas mais de duzentas páginas desse livro dentro do livro que é a Apologia de Raymond Sebond.

Tendo se fixado essa imagem e conferido à Apologia a centralidade das atenções, é todo o conjunto do pensamento que se vê afetado por leituras que não podem se desvencilhar dela. O viés crítico toma a frente e, mesmo quando compensado por considerações sobre os desdobramentos e consequências éticos e os traços e características estéticos da obra, tudo se ordena, em última análise, em função da posição de "suspensão de juízo" instaurada pela dýnamis cética e a consequente "tranquilidade" que daí decorre. Quer se faça dos escritos de Montaigne uma potente exploração e registro da diversidade e variedade das coisas exteriores ou das manifestações do Eu, quer se 
considerem os seus exercícios de julgamento uma potência crítica contra as "ideologias", quer se veja no livro um conjunto de testemunhos distanciados e lúcidos sobre a mesma variação externa e interna no tempo, o que se perde, assumida essa posição, é a qualidade positiva mesma de toda exploração montaigniana da variação. O ceticismo e sua crítica epistemológica, sendo uma dimensão inegável da obra, acabam se tornando dimensão quase exclusiva, acabando por determinar o modo como compreendemos a orientação dela para o domínio prático e sua conformação retórico-poética.

Este trabalho, sem negar - como poderia? - a presença e o peso da argumentação cética n'Os Ensaios como uma de suas dimensões, tentará, no entanto, trazer para o centro da discussão outras dimensões e outros elementos, que compõem certamente com o ceticismo, o todo rico e variado, aparentemente desordenado e monstruoso, do retrato de Montaigne.

Sabe-se que Montaigne, por volta de 1576 ou 1577 mais ou menos, passa a conceber o livro que vem escrevendo como um retrato ao natural de si mesmo, votado, como nos diz, à comodidade de seus parentes e amigos, que em breve virão a perdê-lo. O texto que nos informa essa intenção explícita é a nota que dirige ao leitor na abertura de seu livro, já em sua primeira edição de 1580.

Diga-se, já de saída, o que este estudo considera fundamental. O que se inscreve nas páginas d'Os Ensaios é um retrato. O próprio Montaigne manifesta explicitamente ser essa a sua intenção ao compor a sua obra. Esse será o seu intento, se não desde o início do retiro e da decisão de escrever o livro, ao 
menos desde uma data bem anterior à publicação da primeira edição da obra, em 1580. Obra, portanto, em que pretende deixar os traços de seu caráter inscritos para a posteridade. Não se poderia marcar com mais força a presença de uma problemática ética no livro, a concorrência e imbricamento entre a tarefa "artística" ou "técnica" de produzir uma obra escrita e a decisão "ética" de ordenação dos costumes ou de condução da vida. Assim, Montaigne não só faz do livro um instrumento dessa ordenação, como também, num mesmo movimento, pretende inscrever, em suas páginas, o seu próprio éthos.

Já se afirmou que Montaigne reivindica para os seus escritos uma "irregularidade profunda", associando o princípio que estrutura seu primeiro livro à ideia de grotescos ou monstros fantásticos. E, de fato, quem folheia e lê ao acaso algumas páginas d'Os Ensaios não deixa de ter a forte impressão de uma enorme liberdade e espontaneidade no andamento do pensamento que vai percorrendo uma variedade notável de matérias ao ser registrado no livro. Este efeito primeiro na recepção, bastante vertiginoso, tem sido há bom tempo interpretado como uma "desordem" não só intencional e reivindicada pelo Ensaísta para os seus escritos, mas necessária e intrinsecamente ligada ao seu modo de conceber os homens e o mundo, e, sobretudo, à crítica epistemológica radicada, como se sabe, no ceticismo pirrônico.

É inegável, pois, que na intenção de pintar um "retrato ao natural" presente n'Os Ensaios reina uma grande "liberdade e licença". Esta, efetivamente, é a impressão primeira de todo aquele que se detém na leitura de umas poucas páginas do livro, uma impressão amplamente reforçada por 
alegações explícitas do Ensaísta, espalhadas pelos capítulos, sobre a conformação dos seus escritos, que assumem a forma de um "passeio do julgamento" (promenade du jugement; cf. I, L, 289) ou de um vagar do espírito secundado pelo estilo: "Mon style et mon esprit vont vagabondant de mesmes" (III, IX, 973). Ora, seria esse um motivo suficiente para assumir que se trata de uma "empresa" governada pelo acaso, um livro que dispensa toda ação regrada que o ordene, uma produção, de fato, "fortuita e impremeditada" onde se inscreve e exibe despreocupadamente a "desordem" de um pensamento vão e digressivo? Ou, por outra via, poderíamos entender que a "desordem" inscrita no curso dos arrazoados põe à mostra a intenção de manter-se separado dos movimentos de pensamento que ali se inscrevem, como se Montaigne mesmo, ao acolher os discursos das autoridades e da tradição, apenas o fizesse como uma testemunha lúcida dos desvios e desvarios da razão dogmática, que ele, de resto, assume pontualmente às vezes, a título de convicção pessoal sem outro esteio ou caução? Em suma, a mera presença da liberdade e da licença reclamada por Montaigne basta para afastarmos da obra toda ideia de um "dever", de pensador e de escritor, a que se deva atender e que se deva cumprir, e dos preceitos e modelos autorizados que lhe guiam o exercício do pensamento e a produção do escrito? E, poderíamos pensar ainda que tal 'liberdade e licença' por si só despede toda ideia de uma "razão" que governa essa atividade e produz a obra como retrato do seu autor, em troca de uma atenção que se mantém ativa somente na medida em que registra os movimentos fortuitos do espírito? Em última conta, é pois para a presença ou 
não de uma razão que governa os movimentos delicados de cada um dos ensaios, julgando a oportunidade das escolhas feitas pela manus do ensaísta, que se trata de chamar a atenção aqui. É para a atividade (racional) mesma, que redobra o "abandono" nonchalant ao instante, em que se delicia Montaigne e que podemos ler no último dos capítulos do livro, que se adverte aqui.

Tem-se amplamente acreditado que os Ensaios de Montaigne inauguram uma nova época, ou, ao menos, constituem o limiar de uma grande ruptura. $O$ indício mais seguro disso é a persistência de alguns motivos no campo do comentário: no que diz respeito ao saber e ao conhecimento, o Ensaísta, se não inaugura, ao menos seria dos principais promotores, no mundo moderno, de uma idade da crítica renascente, que colocará radicalmente em questão todo o repertório de ideias e crenças herdadas do mundo antigo e mesmo cristão. No que concerne à moralidade, outro aspecto fundamental da obra, o projeto de autorretrato que ganha corpo no livro representaria um passo decisivo na mudança de perspectiva e de preocupação, inaugurando um tempo em que o indivíduo e a subjetividade entram em cena e a dimensão normativa da ética é substituída por um estudo minucioso e profundo, mas tão só descritivo, dos costumes, hábitos, disposições e intenções do homem, deixando-o, redescoberto e sempre a redescobrir, sem se ocupar mais com tarefas tais como 
a sua educação e condução para a excelência e boa vida, que haviam primado entre os assim chamados humanistas.

Termos como novidade, autenticidade, originalidade, liberdade de pensamento e de ação, crítica e autonomia abundam nesse campo. E presidem os esquemas explicativos propostos para a obra, sempre em busca da singularidade inusitada que ela representa. Digamos que o páthos do "novo" impera, com raras exceções, na compreensão do pensamento de Montaigne. $O$ que se pode perguntar aqui, num primeiro momento, é se o que Montaigne nos propõe em seu livro é compatível com essa proliferação de preocupações muito nossas. Mesmo quando pensado como primeiro momento ou passo de um desenvolvimento que vem até nós, e que, apesar de distante, o aproxima de nós, é de se perguntar também se, movidos por essa paixão, alimentada pela necessidade de reconhecer lá um conjunto de preocupações que nos concerne, não deixamos escapar algo que a obra pode nos ensinar naquilo que tem de comum com o seu século e com a forma mentis do seu tempo, e que está em estreita relação com o seu próprio passado.

Não é, assim, totalmente seguro, já numa primeira abordagem, que a presença da liberdade e da licença nos escritos acarrete uma ruptura profunda com as lides dos letrados humanistas que se pautam pelos ensinamentos das preceptivas no tempo de Montaigne. Sobretudo dos preceitos da ética antiga, no que concerne à ação, e os da arte retórica, no que concerne ao discurso. Nesse ponto, a recorrência das alegações montaignianas contra o artifício nessas duas esferas, tomados em sua literalidade simples, tem pesado bastante para se fixar 
uma imagem do ensaísta e do ensaio em franca ruptura com o tempo e já antecipando motivos e temas muito posteriores, em que uma autonomia do indivíduo já plenamente constituída ganha a cena, toma a palavra e reclama um lugar. O que se vê, então, são leituras que nos pintam um Montaigne já assaz moderno, talvez mais envolvido com as nossas questões do que com as de seu tempo, no que diz respeito tanto ao conhecimento, como à ética, como ainda à técnica de produção do discurso. Visão, obviamente, alimentada pela estreita relação do pensamento montaigniano com o Ceticismo em sua crítica das doutrinas e preceitos dogmáticos. Quanto a isso, antes de avançar a tese de uma ruptura com os modos humanistas de pensar e discorrer, pensamos ser mais natural investigar o sentido e os efeitos dessa precipitação de tópicas relacionadas ao "natural" e sua adequação e oportunidade no contexto da obra que se intenta e produz. Assim, a liberdade requerida, e a licença pedida, podese mostrar que convergem com a plena consciência de um "decoro", de regras de "conveniência" que são, oportunamente, ou obedecidas ou trasgredidas, no constante diálogo que Montaigne mantém com suas fontes. E, mais importante ainda, são dominadas com mestria por uma vis instruída e exercitada que a manière montaigniana ostenta, em seus desempenhos, na obra. O modelo assumido, pode-se dizer, permanece sendo a "natureza", mas a "representação" que dela se dá é fruto de uma reconquista e retomada dessa mesma natureza pela arte, o que já implica discutir a forma de racionalidade posta em prática n'Os Ensaios. 
Tanto mais adequada e oportuna é a insistência e constância dessas tópicas ligadas ao natural em um livro que se pretende um retrato e em que, não seria exagerado afirmar, se defende como um dos valores máximos a fides que estabelece e mantém os laços entre os homens. O falar de si impõe, como dever, a fidelidade na descrição, a franqueza e a espontaneidade naturais do autor imitadas, "sem contenção e artifício", na obra. Seria um erro de juízo falar mais ou menos de si, falar mais do que se é, ou menos. Seria ser presunçoso num caso, tolo no outro. Montaigne tem plena consciência do problema. Não há porque dissimular e apresentar-se diferente do que é, com crenças diversas das que tem. Não há porque pintar-se em cores diferentes daquelas que tem naturalmente. A veracidade e a franqueza se tornam uma questão urgente. Isso não exclui o supremo artifício, o pleno domínio da arte que se oculta enquanto arte e finge ser natureza, mas simplesmente o instala no coração deste livro que tem na fides um valor tão alto. Pois, trata-se precisamente de produzir um discurso em que a confiança se restabelece, o que não pode ser feito senão reconquistando aquela mesma naturalidade por uma estratégia e astúcia supremas da arte. Por uma operação de "retórica superior", já se disse ${ }^{5}$.

Ora, como indicamos, a imagem d'Os Ensaios que tem se consolidado, parece um tanto avessa à instituição mencionada e às suas práticas regradas, com raras exceções. O mainstream do comentário, embora progressivamente venha dando maior atenção à forma de agenciamento dos enunciados quase

\footnotetext{
${ }^{5}$ Fumaroli, M. "Les Essais de Montaigne: l'éloquence du for intérieur". In La Diplomatie de l'esprit. De Montaigne à La Fontaine. Paris: Hermann, 1994.
} 
todos herdados e imitados da antiguidade, tem-no feito a partir de uma perspectiva e empregando categorias em ampla medida estranhas ao tempo. Em outras palavras, não se têm dado suficiente atenção à arqueologia de noções, categorias e lições daquele tempo que pudessem nos informar com maior pertinência sobre dois pontos: (1) o modo de o pensamento montaigniano (e o pensamento dos assim chamados humanistas, em geral) se relacionar com o passado e se apropriar dele; (2) o modo de reordená-lo e repropô-lo, engenhosamente, num presente diverso daquele em que foram formulados primeiramente esses pensamentos.

Obviamente, esse "apagamento do antigo" é bastante interessado, e não deixa de ser interessante. $O$ que se tem acentuado a partir dele é o caráter eminentemente crítico e autônomo, quanto ao saber e ao fazer, que já nos apresentaria a obra montaigniana, antecipando temas e problemas da filosofia que se inaugura no início da modernidade. A tendência dominante - e só se pode falar em dominante aqui, diante da enorme variedade dos estudos aproxima Montaigne das nossas preocupações modernas. E ser moderno aqui significa fazer ruir pela acerba crítica um passado morto, livrar-se do peso da autoridade e talvez reconstruir o saber e orientar o fazer, assentando-os em novas bases, com valorização do indivíduo e da sua experiência controlada pela razão, contra as hierarquias e as autoridades. Some-se a isso o fato de que nos é extremamente cara essa imagem de crítica e de autonomia e que a associamos à própria prática da filosofia desde Sócrates pelo menos. É um 
sujeito já moderno que começa a se levantar no horizonte através da fala dissolvente do pirronismo reativado e, quem sabe, renovado por Montaigne.

Talvez não seja o caso de negar, mas apenas de matizar esse quadro, aliás sumaríssimo, apontado aqui. Como quem quisesse misce(re) stultitiam consiliis brevem, ${ }^{6}$ "misturar aos sérios pensamentos um breve desvario", e temperar nossa severidade, bem ao modo montaigniano e horaciano, com o riso e a hilaridade, este estudo tentará orientar-se menos pela exploração dos haveres, que serão reconhecidos e contabilizados certamente, e mais pela dos deveres, isto é, as dívidas que tem com o passado. O que para nós significa investir fortemente nos traços históricos da obra. Não faz sentido ler os Ensaios subtraindo-os aos meios pelos quais se ensinam e se produzem discursos ainda no séc. XVI; da mesma forma, não parece juízo muito seguro, retirá-los do horizonte normativo das éticas antigas, já que eles se constróem no diálogo cerrado com elas e parece animá-los o mesmo impulso de ordenação da vida lá presente. Os Ensaios, desde há muito se sabe, nascem das leituras, comentários e costura de textos dos antigos. Partindo dos temas e problemas, mobilizando as mesmas categorias morais, políticas, e mesmo metafísicas, perfazem caminhos orientados ainda pelas preocupações dos antigos. No meu modo de ver, as normas de produção do discurso que explana o pensamento, e as normas de condução da vida não poderiam, pois, ser, sem mais, descartadas.

\footnotetext{
${ }^{6}$ Horácio. Odes IV 12, 28.
} 
Por outro lado, o intuito aqui é também o de resgatar a cultura da imitação rival, emulação, em que a obra nasce. Só por aí, já se poderia sustentar que a imagem de um passado acrítico, hierarquizado e obediente, não é muito adequada. Não há docilidade propriamente nas lições que Montaigne toma do passado. A cultura antiga, reativada pelos humanismos vários e plurais, era agônica e produzia-se pela emulação, pela "imitação rival". Logo, imitar não significa imediatamente endossar a autoridade de um pensamento, ou dos pensamentos vários de que um autor se vale como fontes. Escrever não significa simplesmente aplicar os preceitos e receitas das artes retóricas de modo irrefletido e servil. A busca da originalidade, então, se fazia ao preço de uma redução bastante arbitrária da cultura antiga à "servilidade ao preceito e ao ensinamento" das autoridades, cultura que seria lastreada na memória, e não no entendimento, cultura que seria acima de tudo da reprodução e do respeito reverente ao passado pleno de respostas prontas e edificantes. Seria possível pensar de modo assim redutor as letras desse tempo? Não seria adequado tentar recuperar arqueologicamente algumas categorias e formas de pensar e proceder que presidem a sua produção, antes de pensar em rupturas? Enfim, o valor, a medida da excelência, se faz no interior de uma cultura intensamente agônica, mas sem o páthos do novo, do original. É preciso compreender, não descartar como signo de subserviência, o modo de orientar por conselho, por preceito, por regras, a condução do pensamento, as ações e as produções: entender o modo de o antigo participar da "invenção" do novo. 
Quer, portanto, este trabalho mostrar que existe uma "potência ativa" que produz Os Ensaios como retrato "natural" de seu autor, com o movimento que Ihe é peculiar. Essa "potência ativa", vis, figurada por Montaigne pelas imagens da "mão" e da "cabeça bem feita", dá expressão e produz um efeito de natural bastante desordenado e confuso, visto a grande "variação" a que o pensamento se dá liberdade. Talvez fosse melhor dizer aqui licença. No entanto, essa variação não rompe a unidade garantida pelo nexo do propósito que costura todas as alegações, todos os arrazoados. Tudo, no fundo, converge de modo coerente e coeso, ainda que não conquiste resultados definitivos. Pode-se afirmar que um vínculo de "consequência" preside o andamento, tortuoso sim, mas seguro, do pensamento montaigniano que se ensaia. Toda dificuldade está em mostrar que essa "consequência" não deriva da articulação que prende meios a fins, mas afirma como "fim interno" cada um dos passos dados no arrazoado. Cada passo pertinente deriva de um ato decoroso ou conveniente do espírito. Como na dança que passa a figurar metaforicamente a imagem da excelência moral para os estoicos, pois representa o passo que se libertou de seu uso instrumental e se afirma em toda sua perfeição, assim no discurso montaigniano, que instaura uma busca sem fim, mas bela em cada um dos seus gestos de pensamento convenientes. Ou seja, o discurso montaigniano não visa um resultado conquistado no final e apenas vislumbrado no início. Sua força está em tomar a palavra e exercer o poder de suas faculdades naturais em 
matérias diversas, reduzidas à mera ocasião de pôr à prova aquelas mesmas faculdades, de fazê-las exercer-se, provando sua capacidade de discorrer pertinentemente sobre qualquer assunto, mas independentemente do conhecimento ou ciência verdadeira que se tem dele. Pertinência, decoro, conveniência são palavras-chave nessa nossa tentativa de comentar as concepções de pensamento e discurso articuladas n'Os Ensaios.

Nesse sentido o pensamento, em seu processo de invenção e explicitação pelo discurso, se afirma como uma potência de eleição e de ordenação de coisas e de palavras. Como o discurso de prudência no caso das ações (e, a propósito, Montaigne separa muito pouco sua atividade de escrita de sua vida e modos de conduta), ele parece dotado de critérios para a escolha reta em cada caso. As coisas, isto é, as concepções das coisas, têm primado sobre o trabalho minucioso com as palavras, indício de afetação e artifício, e nisso Montaigne não afirma nada de original, uma vez que a boa expressão segue a concepções seguras e firmes, como se sustenta em lições tradicionais de retórica e poética. Podemos, assim, nos perguntar sobre o critério que preside a escolha que o juízo opera dos tópicos e também das palavras. O certo é que a consequência deve ser pensada menos como uma articulação sequencial ou sucessiva dos passos que conduzem as "provas", e mais como a coexistência harmônica dos motivos, dos argumentos, das figuras, das citações que são reunidos em torno do tema simultaneamente e concorrem não para o seu esclarecimento, mas para dar mostra das operações do julgamento do próprio autor. A abordagem nem sempre é direta e a digressão tem grande papel nisso, 
pois estabelece relações, distantes às vezes, entre temas aparentemente desconexos.

No entanto, uma dificuldade surge quando se fala em unidade nos textos de Montaigne. A impressão que se tem lendo os escritos do filósofo é de que, de fato, como quis persuadir-nos no Da ociosidade (I, 8), a escrita não passa de expediente para frear os desgarros do espírito ocioso e, ademais, acometido pela melancolia. Ela é registro. Montaigne quis compor um registro de sua própria variação e mudança no tempo: autorretrato, em que ele aparece, não tanto agindo, mas pensando. É pensando que ele se retrata e mostra au vif, como nos diz na nota de abertura do livro, "en [s]a façon simple, naturelle et ordinaire, sans contention et artifice" (I, Au lecteur, 3). Registro sem contenção e artifício; isto é, espontâneo e imediato, sem apuro e sem preceito. O que quer dizer que o acaso ou a Fortuna, que é não mais que a personificação mítica do primeiro, governa seus movimentos. Poderíamos discutir a afinidade entre arte e acaso. Mas, notemos, por ora, que Montaigne insiste tão frequentemente na naturalidade do seu retrato, que nos chega a persuadir de que fala a sério quando afirma sua espontaneidade ao compor o livro. E quão decorosa ela não é num livro em que deseja pintar-se para parentes e amigos quase sem conceder à reverência pública seus limites; já que, sem propósitos explícitos de convencer alguém acerca da verdade do que pensa, nada mais disparatado do que entregar-se ao jogo do artifício e aos discursos premeditados para persuadir. E, além do mais, num livro que propugna tão alta e fortemente o valor da fides, cujo esteio maior para o homem está na palavra veraz, no cumprimento 
da palavra dada. Que ódio não testemunha Montaigne pela mentira no uso que fazemos do discurso e que nos distingue dos animais e instaura as relações e laços entre os homens? Tão grande quanto o seu correlato no âmbito das ações: o vício da crueldade. Como, então, afirmar o uso do artifício nesse discurso eivado da retórica que o combate quase em toda página?

De que espécie e qual o estatuto dado por Montaigne à capacidade, talento instruído e exercitado, de produzir discurso, de inventar e dispor seus arrazoados: a manière montaigniana é, como veremos, produzida por aquilo que - Ensaísta nomeia suffisance de uma teste bien faicte, cujos desempenhos a obra testemunha por ocasião de cada um de seus 'exercícios do julgamento'. Antes, porém, de avançarmos nisto, cabe repassar o que se têm sustentado e como se tem descrito o ensaio pela parte do comentário, o que julgamos essencial para o esclarecimento da questão. Qualquer tentativa de exaurir esse campo estaria fadada, senão ao manifesto fracasso, ao menos à superficialidade. Mas, fizemos aqui escolhas e seleção, elegendo interlocutores e procurando privilegiar, no campo dos estudos, pontos de inflexão e viragem no modo como se interpretou a concepção montaigniana do ensaio. 


\section{Matrizes do comentário contemporâneo (Villey, Friedrich, Tournon)}

O problema com que tem de lidar o comentário acadêmico desde os fins do séc. XIX é uma herança ainda da recepção, por assim dizer, clássica, e vai dos contemporâneos, neo-estoicos, passando por Charron, La Motte le Vayer, Bayle, Pascal e outros, atravessando o século das luzes e chegando até SainteBeuve, pelo menos, que acaba retomando a imagem pascaliana de um ceticismo que desespera de encontrar a verdade. No cerne das discussões, a questão da inscrição doutrinal dos Ensaios. E quando se trata especificamente de ceticismo, com que espécie de ceticismo estaríamos lidando. ${ }^{7}$ Obviamente, a dificuldade de decidir e a oscilação das leituras passam pela "forma" peculiar dos Ensaios e por sua particular "desordem". Logo, depende de uma interpretação do gênero não só praticado, senão mesmo fundado modernamente por Montaigne: o ensaio. Não é à-toa que a primeira grande distorção do pensamento montaigniano se deveu a Charron, devido à reordenação a que ele submeteu seus Ensaios.

A primeira grande tentativa de resolver esse problema da inscrição doutrinal no âmbito dos estudos acadêmicos se deveu, como se sabe, a Pierre Villey. O trabalho é conhecido e basta lembrar que o esquema genético da evolução do pensamento de Montaigne, a luz do fio de suas leituras, leva de um primeiro momento estoico, passando pela relativização da rigidez e da constância dos filósofos do pórtico pelas leituras de Plutarco e pela "crise cética"

\footnotetext{
${ }^{7}$ Os Ensaios, com seu “Que sais-je?", inauguram ou não uma nova zetética, repetem a "zétesis" dos antigos pirrônicos, ou filiam-se ao ceticismo negativo dos acadêmicos.
} 
operada por Sexto Empírico, crise superada finalmente por um naturalismo moral de cunho epicurista. Ao longo desse percurso, o projeto de autorretrato vai se tornando cada vez mais consciente e o Eu de Montaigne vai invadindo progressivamente a cena. $\mathrm{Na}$ tentativa, pois, de dar coerência ao pensamento de Montaigne, Villey renuncia a selecionar e privilegiar alguns de seus traços e escande o pensamento no tempo de sua produção. É menos uma reordenação que se opera nos textos que um trabalho de gênese da filosofia definitiva dos Ensaios, em tudo avessa ao estoicismo de que partira, na maneira como lida com as paixões, a dor e a morte.

Outras tentativas de dar coerência ao conjunto dos textos foram sendo propostas. Dentre elas se destaca a do livro de Hugo Friedrich, de 1949, mas que só ganha impacto no debate depois de sua tradução para o francês, em 1968. Aqui leva-se a sério a existência de uma filosofia montaigniana, valorizando-se o ensaio como forma peculiar de fazer filosofia. O ensaio é para Friedrich uma "forma aberta", oposta às formas sistemáticas de saber, em que se elabora um conhecimento empírico e não normativo do homem. Tanto em sua relação com a cultura, através de suas leituras, quanto em sua relação com a própria experiência, esse modo de fazer filosofia opera uma exploração dos materiais que colhe que já não pertence mais ao campo da moralidade antiga, mas inaugura o que Friedrich chama de "ciência moral moderna", muito mais preocupada em aprofundar e refinar, em seu exame minucioso do homem, o conhecimento sobre ele, do que em educá-lo e ensiná-lo a governar-se - um projeto muito mais curioso do que edificante. Tratar-se-ia de uma exploração 
fenomenológica do homem - instaurada a partir da dúvida cética - que o devolve ao seu lugar de criatura entre criaturas, sem maior dignidade e sem mesmo a possibilidade de pretender a maior dignidade.

Com a liberdade que se dá para reordenar os textos (pois lida com passagens isoladas e não leva em conta a coerência interna dos capítulos), Friedrich detecta na obra uma "dialética" que leva sempre da negação ("humilhação do homem") à afirmação, em dois tempos: a exploração positiva da exterioridade, pela acumulação dos motivos da variação dos costumes, dos hábitos, da diversidade e inconstância dos homens de diferentes lugares e tempos; e a exploração da subjetividade, apreendida na "experiência de si" a que Montaigne se devota em seu projeto de retrato. Este esquema se perfaz por uma consideração detida da morte e acaba por encontrar na "finitude" a condição de existência do homem, que, ademais, abandona toda preocupação com a salvação ou com o aperfeiçoamento moral. A sagesse montaigniana vêse, assim, reduzida a uma entrega nonchalante ao governo da natureza, a uma "coincidência" passiva com a ordem do mundo ${ }^{8}$.

Mas há uma outra vertente, dominante hoje ainda, do comentário, que foi inaugurada por Jean-Yves Pouilloux em 1969. Enquanto a primeira, por

\footnotetext{
${ }^{8}$ Há, certamente, no campo do comentário, outras obras que reordenam à sua maneira os Ensaios, propondo movimentos de pensamento em vista de restituir a coerência ao pensamento de Montaigne. O esquema ternário, dialético, do movimento de constituição da obra proposta pela extraordinária leitura de Jean Starobinski (“Montaigne en Mouvement”) não pretendemos, por razões internas ao nosso projeto crítico, comentar aqui.
} 
manipulações operadas no texto, tentava enfrentar o velho problema de restituir coerência aos Ensaios e mostrar a presença de desenvolvimentos positivos do pensamento de Montaigne, esta outra, apoiando-se no pertencimento dos Ensaios ao ceticismo e na consideração da "desordem" do texto, segue, num primeiro momento, a via negativa da crítica epistemológica, e depois, busca desdobramentos positivos numa ética centrada na ideia de autonomia. Certamente são marcantes nesse ramo do comentário as preocupações com o texto, sobretudo nos estudos de Letras. Já não se propõem mais reordenações. Também a problemática da subjetividade e as explicações que faziam uso de elementos da vida e da história vão sendo apagadas pela preocupação com os agenciamentos complexos de enunciados e com os efeitos de sentido que eles produzem. Decaem as preocupações biográficas, e não se entende mais 0 projeto de retrato como uma "mímese" da interioridade. Pertencem a esta vertente alguns dos estudos retóricos sobre os Ensaios: estudos de crítica literária mais exaltados mobilizam mesmo o tópos desconstrucionista da morte do sujeito. Passou-se a resistir à tentação de pretender que o "eu" dos Ensaios existe independentemente do texto que o constitui.

Não é exatamente dessa radicalidade a leitura dos Ensaios que nos propõe André Tournon. Mas certamente, sua contribuição se deve, em grande medida, a uma preocupação com a leitura integral dos capítulos do livro sem pretender reordená-los, buscando seus movimentos de argumentação e a maneira como absorvem e mobilizam o conjunto de ideias disparatadas e contraditórias constituído pela herança humanista. Não se considera mais 
legítima a operação de reordenar os textos e mobilizá-los num quadro ou esquema, numa "dialética", que restitui coerência ao conjunto. A démarche montaigneana - o ensaio propriamente falando - opera uma encenação desse conjunto variado de ideias, valendo-se da escrita em que vem se espelhar o material examinado. Por isso, Tournon a qualifica como "escrita especular". Por meio dela, garante-se um "deslocamento" e uma "cisão" entre os discursos sobre os quais incide o exame e o "ato de reflexão" pelo qual o escritor pode ou não assumi-los. Ele permanece, como veremos em detalhe mais adiante, em "contracampo", destacado do conjunto de ideias que repassa, e em posição ao mesmo tempo de "testemunha e de juiz" desses discursos. Como, ademais, a operação própria do ensaio desvia o interesse das matérias examinadas para os desempenhos mesmos das faculdades do sujeito empenhadas no exame; as múltiplas investidas do ensaio, em cada capítulo, acabam menos por dar a conhecer algo sobre estas matérias do que por esboçar um retrato do próprio autor. Ao ensaiar-se, Montaigne dá mais a ver a si mesmo que as coisas que examina. E das opiniões que endossa, não garante mais do que a marca de uma escolha pessoal refletida, cuja fragilidade só poderia ser acusada, se fizéssemos abstração do ceticismo que "funda" essa posição. Mas guardemos para depois o esmiuçamento dessa tese lembrada aqui em suas linhas gerais e retomemos, agora um pouco mais detidamente, começando por Villey, os momentos centrais do nosso percurso crítico. 


\section{a. Pierre Villey, o trajeto de constituição do 'ensaio'}

Vem de fins do século XIX o início dos estudos acadêmicos sobre a obra de Montaigne, e foi Pierre Villey, um discípulo de Gustave Lanson, seu maior representante. É de 1908 seu Les Sources et l'Évolution des Essais de Montaigne. Trabalho monumental, nele delineiam-se, através de um estudo genético da relação do pensamento montaigniano com suas fontes (os textos que nosso autor progressivamente lê e compulsa, desde seu retiro letrado), os contornos da composição do livro ao longo do tempo de sua produção ${ }^{9}$. O livro, como se sabe, conheceu, em vida do autor, ao menos três edições (1580, 1582 e 1588), além da edição póstuma de 1595, tarefa de que se incumbiu Marie de Gournay, a fille d'alliance de Montaigne, e que teve por base o Exemplar de Bordeaux, com os acréscimos manuscritos à margem de uma edição impressa de 1588, preparados pelo ensaísta para uma nova edição, que não chegou a realizar, pois a morte o colhe em 1592. É com base nesse conjunto de edições, inclusive o exemplar anotado por Montaigne, que se prepara a edição crítica, chamada "Edição Municipal", a partir da qual as camadas de texto e as modificações (normalmente marcadas pelas letras [A], [B] e [C] no corpo do texto ou à margem) passam a ser amplamente consideradas. Pois, desde então,

\footnotetext{
${ }^{9}$ Para que esse trabalho se tornasse possível, vindo a integrar definitivamente o horizonte do comentários da obra de Montaigne, foi fundamental a preparação da edição crítica d'Os Ensaios, pelo mesmo Villey e por outros dois estudiosos, Strowski e Gébelin, tendo como base o "Exemplar de Bordeaux", publicada de 1906 a 1933, e que resulto na chamada "Edição Municipal". A obra montaigniana passa, então, a ser pensada definitivamente como um "registro de duração" (registre de durée), na expressão tomada ao próprio Montaigne
} 
os trabalhos acadêmicos têm levado em conta esse traço de "registro de duração" - para empregar uma formulação da mão do próprio autor -, que tem marcado e determinado, em grande medida, o entendimento e a interpretação do ensaio. É, assim, no movimento traçado pela "evolução" do pensamento, a partir do impacto das leituras, que Pierre Villey data e inscreve as diferentes concepções do ensaio que vão se sucedendo ao longo da composição do livro. Acompanhemos, portanto, a sua reconstituição. Percorreremos com o comentador um conjunto de textos em que aflora a "consciência refletida" de Montaigne sobre sua própria empresa de pensamento e escrita.

Villey ${ }^{10}$, logo de início, aponta (para louvá-la) a novidade do nome estampado no frontíspicio de um livro publicado em 1580: Les Essais. Mas não só a novidade do nome, pois é frisada também aquela da própria coisa, o que vem corroborar a passagem da missiva endereçada por Montaigne a Mme. d’Estissac no início do "De l'affection des pères aux enfans", que vale reproduzir:

“[A] [...] si l'estrangeté ne me sauve, et la nouvelleté, qui ont accoustumé de donner pris aux choses, je ne sors jamais à mon honneur de cette sotte entreprise; mais elle est si fantastique et a un visage si esloigné de l'usage commun que cela luy pourra donner passage."

\footnotetext{
${ }^{10}$ Cf. Os Ensaios de Montaigne. trad. Sérgio Milliet. In Montaigne. Ensaios II. Rio de Janeiro, Porto Alegre, São Paulo: Editora Globo, 1960, p. 3 - para a reconstituição breve da leitura de Villey, valho-me aqui desse texto menor, tradução de um livrinho da coleção "Les grands événements littéraires", publicado em 1932 pela editora Nizet, que condensa o essencial da tese Les Sources et l'Évolution des Essais de Montaigne, Paris: Hachette, 1906, revisada em 1933.
} 
[ [...] se a estranheza não me salvar, e a novidade, que costumam valorizar as coisas, nunca sairei honrosamente deste tolo empreendimento ; mas ele é tão fantasioso e tem um ar tão distante do uso comum que isso Ihe poderá abrir caminho.] (Les Essais, II, 8, 385)

Não avaliaremos agora o sentido e alcance dessa "estranheza" e "novidade" referida por Montaigne aqui ao recomendar seu livro e avaliar a possibilidade de seu sucesso. Continuemos, na pista de Villey, a percorrer as declarações explícitas de intenção que colhe nos Ensaios, buscando, com ele, avaliar "em que consiste um ensaio no pensamento do Montaigne de 1580" (p. 3). Pois, apoiado em suas hipóteses de datação, o autor percorre as declarações de intenção anteriores à data da primeira publicação do livro, começando por aquela formulada por volta de 1571, no primeiro livro, no capítulo sobre a "ociosidade". Montaigne escreve:

"[A] Dernierement que je me retiray chez moy, [...] il me sembloit ne pouvoir faire plus grande faveur à mon esprit, que de le laisser en pleine oysiveté [...] Mais je trouve [...] que au rebours, faisant le cheval eschappé, il se donne cent fois plus d'affaire à soy mesmes, qu'il n'en prenoit pour autruy; et m'enfante tant de chimeres et monstres fantasques les uns sur les autres, sans ordre, et sans propos, que pour en contempler à mon aise l'ineptie et l'estrangeté, j'ay commancé de les mettre en rolle, esperant avec le temps luy en faire honte à luy mesmes."

[ [A] Recentemente, ao isolar-me em minha casa [...] parecia-me não poder fazer maior favor a meu espírito do que deixá-lo em plena ociosidade 
[...] Porém descubro [...] que ao contrário, imitando o cavalo fugido, ele dá a si mesmo cem vezes mais trabalhos do que assumia por outrem; e engendra-me tantas quimeras e monstros fantásticos, uns sobre os outros, sem ordem e sem propósito, que para examinar com vagar sua inépcia e estranheza comecei a registrá-los por escrito, esperando com o tempo fazer que se envergonhe de si mesmo por causa deles.] (I, 8, 32-3)

A data aproximada de 1571, lembra Villey, baseia-se na afirmação de que "[se] retirou ultimamente" ao castelo. O importante aqui é que, por ora, nota o comentador, Montaigne nem emprega ainda o termo ensaio ou ensaios, com que designará sua obra, e nem mesmo apresenta e discute traços que caracterizem a concepção que deles fará posteriormente. Mas alude já aqui, embora ausente o termo, a um dos sentidos correntes no tempo, como o que Marot dava à sua Adolescence Clementine, chamando a sua obra de "coup d'essai", que podemos traduzir como "tentativa" (ou mesmo "primeira tentativa"). Portanto, se não uma primeira definição, surge aqui uma primeira acepção, ligada ao sentido "modesto" associado à palavra, haja vista o traço depreciativo com que aparece caracterizada a tarefa de "arrolar" (mettre en rolle) os "monstros e quimeras fantásticos" gerados pelo espírito plenamente ocioso. Montaigne, porém, não demorará a empregar o termo, ainda no primeiro livro.

Em seguida, ainda lendo as declarações de intenção de Montaigne, surge o termo associado à ideia de que, no livro, estão presentes "as experiências a que procede o seu julgamento". Como interpreta Villey, Montaigne nos explicaria 
sua empresa nos seguintes termos: "a propósito de todos os assuntos que ventilei propus-me a mim oferecer-vos uma opinião pessoal" (id. ibid., p. 4). Também esse traço de juízo pessoal sobre os assuntos manter-se-á, diz ele, como um dos elementos da concepção definitiva.

Porém, Montaigne não se detém aí; pois, por volta de 1580, ou seja, perto da primeira publicação dos Ensaios, apresenta uma terceira e última concepção: o livro "compõe os ensaios de sua vida", isto é, Montaigne nos "apresenta [sua] experiência pessoal sob todos os aspectos" (id. ibid.). É a ideia do autorretrato que desponta aqui. Nas palavras de Villey, "os Ensaios tornaram-se a pintura do seu Eu, reflexões sobre seus pensamentos e suas ações" (id. ibid., p. 5). Antes, pois, de alcançarmos esta formulação "deparamos com os sucessivos esboços em que [Montaigne] tentou fixar no papel sua personalidade instável e os diversos aspectos de sua experiência" (id. ibid.), de modo que a ideia do autorretrato é uma concepção conquistada ao longo de um percurso biográfico, precedida por outras, menos originais e novas, que permaneceram, nada obstante, como traços pertencentes ao ensaio. Assim, a "modéstia" no registro das fantasias do espírito ocioso. Assim também, a ideia de que ensaia o julgamento em diversas matérias, oferecendo uma opinião pessoal acerca delas (id. ibid., p. 3-5).

A pergunta que Villey se põe e que organiza toda a reconstrução desse percurso é a de "como chegou então a conceber esse desígnio" (id. ibid., p. 6). Trata-se para ele de percorrer etapas de uma vida (em especial da vida intelectual do autor, a partir de seu retiro) e de mostrar como, a partir do impacto 
das leituras que vão sendo feitas, a experiência pessoal de Montaigne no tempo - que é de grandes provações - e as lições próprias "decantadas" dessa experiência - mais do que o repertório comum e pouco adequado às inclinações do autor presente nos escritos iniciais - vão assumindo o primeiro plano, a ponto de o livro se tornar um retrato do autor no termo final de um movimento que empurra paulatinamente o Eu para o palco d'Os Ensaios. Repassemos em grandes linhas essa leitura paradigmática para os estudos montaignianos. Ela nos servirá, ademais, para apresentar, muito brevemente, Montaigne e sua obra e introduzir, aqui, o leitor menos familiarizado no conjunto de problemas e temas presentes n'Os Ensaios.

Villey, de início, repassa os anos de formação do autor, desde o nascimento: a posição social conquistada pela família (enriquecida no comércio e enobrecida com a aquisição recente das terras de Montaigne), as etapas da educação (um preceptor alemão que ensina latim como primeira língua, o colégio de Guienne, os supostos estudos de direito), o exercício da magistratura dos 21 aos 37 anos (e as lições que tira dos processos, do horror das torturas, da venalidade dos cargos, etc.), e, nesse meio em que muitos eram homens bastante cultos, a amizade excepcional cultivada com essa "alma à maneira antiga" que foi La Boétie. De toda a educação recebida e da convivência nos meios intelectuais dois traços sobressaem: em primeiro lugar, observa-se que, 
pela educação propiciada pelo pai, não se combatem os principais aspectos do temperamento e das inclinações naturais do menino Michel, que se mostra desde cedo um tanto "indolente", avesso a todo esforço duradouro - um traço que será importante para o desdobramento de suas concepções morais mais maduras e para a forma do ensaio. Em segundo lugar, Villey observa que despontam nele (como resultado desta educação em que pôde aprender "o amor aos livros e gosto pela cultura do espírito") ambições literárias, a despeito das desculpas costumeiras que, como fidalgo, dará sobre a tarefa de escrever aos seus iguais, damas e senhores da nobreza, querendo distinguir-se dos "fazedores de livros".

Assim, quando chegamos ao tempo em que abandona a magistratura e consagra-se ao seu "retiro", em 1571 (dentre cujas motivações provavelmente poderiam contar-se os impedimentos para ascender a um posto mais elevado numa outra "Câmara"), Montaigne, movido por sua ambição literária, já ensaiara tornar-se autor, num gênero, embora, muito distante das confidências pessoais que povoarão as páginas mais desenvoltas d'Os Ensaios. Como relembra Villey, ele é tradutor do Liber Creaturarum sive Theologia Naturalis do teólogo espanhol Raymond Sebond, tendo empreendido tal tradução, ao menos segundo a excusa que nos oferece, a pedido do pai. Por este tempo também, publicava os opúsculos do amigo perdido em 1563 e vendia seu cargo a Florimond de Raymond, retirando-se, então, para sua propriedade; de um lado, por desejar "levar [...] a existência brilhante de um castelão, [...] administrando sabiamente o patrimônio"; por outro, porque, "cansado também dos cargos públicos que não 
convêm a sua indolência, aprecia os lazeres estudiosos, aspira a essa sabedoria antiga que só se cultiva na leitura e na meditação" (cf. id. ibid. p. 13). Trata-se de $\mathrm{m}$ herdeiro, munido dos frutos de uma cultura esmerada, que se recolhe ao ócio em meio aos livros (em parte oriundos do espólio do amigo e dispostos agora na torre, nas prateleiras de sua biblioteca).

Estamos no tempo da composição dos primeiros capítulos, que Villey data dos anos 1571-72 e qualifica de "impessoais". Montaigne, então, não imaginara ainda a forma original de sua obra e pratica um gênero comum em seu tempo: as leçons. No fundo, ele lê muito (historiadores, compiladores e moralistas) e "consigna o que o impressiona em suas leituras" (id. ibid., p. 14). Isso dá origem a três espécies de dissertação, nas quais os "elementos essenciais" são "exemplos comentados, casos singulares, preceitos de moral antiga" (id. ibid., p. 17). De Montaigne, apenas o fio da escrita que costura esse amontoado de exemplos, sentenças e lugares-comuns, intercalando alguns comentários seus, num conjunto de capítulos bastante curtos, compatíveis, ademais, com sua "indolência" e curiosidade. Mas tais escritos pertenceriam a uma corrente comum em voga e atenderiam a uma necessidade intelectual da Renascença, que, invadida por noções novas, tanto as resgatadas do passado, como as advindas das notícias do Novo Mundo, necessitava inventariá-las e compilá-las. Nada, portanto, de pessoal nesses primeiros capítulos.

Impessoais tanto na forma, como no conteúdo que neles se vaza: seu modelo de virtude no tempo é Catão de Útica e seu mestre e autor predileto é Sêneca. Dessa forma, os primeiros textos deixam-se fortemente impregnar de 
estoicismo (cf. id. ibid., p. 17-19). No comércio com La Boétie já havia despertado nele o projeto de não só apreciar a beleza estética das obras, como também levar seus exemplos e ensinamentos à prática, de tal modo que Montaigne se imbui da intenção de "assimilar o espírito da sabedoria antiga, fazer reviver essa sabedoria". Esse um dos primeiros objetivos de Montaigne n'Os Ensaios (cf. id. ibid., p. 10). E no comércio com La Boétie, igualmente, prevaleciam fortemente os traços do esforço moral próprio da doutrina estoica. Essa primeira filosofia moral "pregada" pelo autor, porém, segundo Villey, tem pouco a ver com sua experiência pessoal, que não se acha depositada nessas páginas. São furtos, empréstimos, nada que condiga com a personalidade, nada que se ajuste à medida do $E u$.

Mas já aparece aqui um traço importante de ecletismo, presente também em Sêneca (que não se proíbe de mobilizar outras doutrinas, como o Epicurismo, por exemplo). Pois, não se tratava de fazer reviver uma doutrina ou seita em sua integridade, mas de reter o espírito comum a todas as seitas, ou seja, tratava-se de aplicar "o método racionalista em moral" (cf. id. ibid., p. 19). E das aplicações desse método, por esta época, Montaigne parece seduzido, sobretudo, pela ideia de "esforço moral" (cf. id. ibid.), de onde a prevalência de motivos estoicos. Este esforço, que aposta numa razão capaz de transformar profundamente nossa natureza, de elevar o homem, mediante uma tensão constante da vontade, acima da humanidade, o que constitui o ponto central de suas lições de 1572. A razão - que recomenda o afastamento e a solidão para o homem, combate as paixões, a dor e o medo da morte e deles triunfa - é o 
ponto de apoio dessa vontade lutadora que, diferente da vontade natural, desafia com esforço e tensão os males, privilegia a alma, despreza o corpo e o vulgo (que está próximo da despreocupação típica do animal), e tem por modelo homens excepcionais, em situações que pedem atitudes de grandeza.

Villey nota que esta moral, além de ser estranha à experiência pessoal de Montaigne, seria mesmo incompatível com o seu temperamento. Sem recusar a hipótese de que circunstâncias passageiras o colocaram à prova (adversidades da guerra e da doença, bem como a proximidade da morte) e o levavam a buscar nessa filosofia os meios de resistir, a leitura aposta aqui, antes, na "influência do ambiente intelectual". É mais a "imaginação" de Montaigne que se empolgava com Sêneca, e menos "a razão e o coração". Ele admira o que não é capaz de imitar. Entusiasma-se com sinceridade, mas o entusiasmo é "literário" (cf. id. ibid., p. 23). Tanto é assim que sustentará uma moral totalmente contrária ao final do percurso que estamos repassando, uma moral compatível com seu temperamento e inclinações, que vão, no livro, ganhando a cena, às expensas do pensamento alheio que anima essas primeiras produções.

Ora, é sob a influência da leitura principalmente de Plutarco e Sexto Empírico, que se dará a passagem dessa primeira à "filosofia definitiva d'Os Ensaios", com mudanças sensíveis nos modelos, bem como na concepção de virtude, na relação com as paixões, na sua avaliação do comum dos homens, na sua reflexão sobre a morte. Também a forma como Montaigne escreve vai progressivamente mudar, tornar-se mais segura e desenvolta, menos concisa e mais livre, muito mais adequada à expressão das experiências do $E u$. E nos 
escritos virão se espelhar as opiniões, crenças e ações do indivíduo, na forma definitiva que assumirá o ensaio. De fato, uma inclinação natural a falar de si, nota Villey avançando, sempre esteve presente nele, por exemplo, na forma como em 1573, narra a recordação da experiência de um desmaio, em consequência de uma queda de cavalo que sofrera seis anos antes (cf. Os Ensaios II, VI, "Da ociosidade"). Na maneira como Montaigne se demora na narrativa do ocorrido, que representa uma espécie de antecipação da experiência da morte, transparece já muito mais o prazer de relatar do que a advertência de que a morte não nos deve apavorar, associada sempre à tentativa de nos convencer a enfrentá-la impassivelmente, dando prova de constância - compatível com sua primeira filosofia que apregoa a praeparatio mortis.

É, contudo, nas Vidas Paralelas e nas Obras Morais de Plutarco (traduzidas por Jacques Amyot) que Montaigne encontra um primeiro impulso e encorajamento para abandonar sua "primeira maneira". Fará dos opúsculos seu "breviário", com seus exemplos morais simples, todos comentados e meditados, acompanhados do "juízo mais reto que jamais houve". Neles a observação da vida privada (a de todo mundo) prevalece, não a trama das ações públicas, fazendo Montaigne encontrar nesta leitura um "prolongamento da experiência moral própria". Em suma, são dois serviços que Plutarco presta a Montaigne: primeiro, habitua-o a observar-se mais de perto e a observar os outros em torno de si; depois, ajuda-o a descobrir em si mesmo uma moral oposta à que professava em 1572. Com o seu exemplo de filosofia amena, "feita de 
moderação e bom senso, de justeza e benevolência", Plutarco revela Montaigne a si mesmo e este passa a combater a altivez arrogante dos estoicos e assume que o "homem não passa de um homem". Ademais, descobre que vai bem em um livro uma "moral sem ostentação, ou desmedida ambição", contrária a afetação e às nobres atitudes usuais quando se fala ao público. A leitura de Plutarco, portanto, leva Montaigne a "ousar propor uma sabedoria modesta e familiar", mais coerente com seu próprio temperamento.

Um segundo impulso, entretanto, por uma "via indireta, mas segura" ajudará Montaigne a chegar a conceber seu livro como uma pintura do Eu. Trata-se da leitura de Sexto Empírico, cujo impacto e impressão no autor d'Os Ensaios pode ser medido pelas marcas exteriores de que se cerca Montaigne no período em que o lê. Manda cunhar uma medalha em 1576, com uma balança e a inscrição, em forma interrogativa, célebre doravante: “Que sais-je?”; e também multiplica as inscrições de teor cético nas vigas da biblioteca. Pode-se admitir, observa Villey, que o terreno estava preparado para o florescimento da dúvida. A revolução intelectual do Renascimento era propícia ao Ceticismo, pois a soma dos conceitos oriundos do passado e a novidade do Novo Mundo vinham quebrando o quadro tradicional de pensamento da Idade Média. Emergia, então, e dava-se à curiosidade um conhecimento dos usos, costumes, crenças e instituições muito variados e contraditórios. Essa experiência do século, que é a experiência da diversidade e contrariedade de fatos e de ideias, inclinava já à suspensão do julgamento um Montaigne leitor dos historiadores e crônistas de viagens, que a leitura de Sexto e a crise pirrônica só viera fortalecer. 
Ora, é na Apologia de Raymond Sebond, o maior e mais influente dos ensaios de Montaigne, nota Villey, que se encontra o principal registro dessa crise pirrônica. Nela se expõe, a propósito da defesa do intento de Sebond de demonstrar todas as verdades da fé somente com a razão, o ataque fulminante a que o filósofo submete o homem, em sua vaidade, e o conhecimento, criticado em seus efeitos (a ciência), em seu instrumento (a razão) e em suas matérias (os dados colhidos pelos nossos sentidos). Como resultado, duas conclusões importantes serão tiradas por Montaigne dessa fase, uma delas, definitiva, acerca da "relatividade fundamental" de todo conhecimento; a outra, ocasional, acerca da adesão provisória de Montaigne ao Ceticismo, pois, durante um tempo este se acreditará com fervor um "puro pirrônico".

Mas, para Villey, além de ser apenas uma crise passageira, sua adesão à escola de Pirro não constitui uma posição destruidora. Por um lado, porque um dos resultados da crise é o de que o Ceticismo é posto a serviço do fortalecimento das "bases tradicionais do pensamento prático", deixando subsistir a adesão às crenças e mesmo as fortalecendo, conservando a obediência aos costumes e as leis. Com ele Montaigne suspende seu julgamento individual e cede espaço a um julgamento coletivo. Como não se põe como adversário da Igreja, embora impressione, não escandaliza. Por meio do ceticismo, Montaigne se associa ao movimento Fideísta do tempo e concilia sua necessidade de filosofar à moda antiga com o crer segundo a tradição, já que a razão não leva a conclusões, deixando o caminho aberto para a Revelação e mantendo a fé ao abrigo dos ataques da razão. Também por meio dele, 
Montaigne se desliga definitivamente da filosofia de Sêneca, que supunha uma fé vigorosa no poder da razão humana que domava as paixões, o medo da dor e da morte.

Por outro lado, um inesperado resultado, e paradoxal, se acrescenta ao primeiro. O Ceticismo dá a Montaigne maior confiança em seu próprio julgamento. Como a crise aprofunda nele, argumenta Villey, o sentimento de que todo conhecimento humano é relativo, ela o torna consciente de uma superioridade: "julga com mais prudência do que os outros", que se repartem em dois grupos: aqueles que estão persuadidos de que são racionais suas crenças, costumes, instituições (os homens comuns); ou aqueles que pensam que são irracionais e precisam ser reformados (os doutos racionalistas que se creem na posse de critério e de verdades que medem o valor das coisas). Montaigne, cético, está fora dessa alternativa: "conforma-se com a tradição, que não o ilude com seu prestígio, porque a razão não é capaz de corrigir a tradição, sem correr graves riscos". Logo, liberto da "pressão mecânica do hábito" e da "confiança cega na razão", toma consciência mais plena da "originalidade de seu bom senso", única "superioridade" de que se jacta. Mas onde fundamenta essa superioridade? Villey nos responde que é na "sujeição dócil aos fatos". E Montaigne, como moralista, reconhece na "experiência pessoal fatos certos, controláveis, iluminados por dentro como por fora". Daí porque, também Sexto leva Montaigne a tomar-se como objeto de sua experiência e reflexão, a examinar-se, impelindo-o a assumir o centro da cena, "empurrando o Eu para o palco d'Os Ensaios". 
No cômputo dos estímulos que levaram ao projeto da pintura do Eu, Villey nota de passagem ainda a leitura dos poetas latinos (Horácio e Lucrécio à frente) e a própria vida de Montaigne, que aos 45 anos, experimenta as primeiras crises de cálculos renais. Um convite a mais para observar-se e estudar-se, tomando nota de suas experiências e explanando, agora, suas próprias ideias sobre a dor e a morte. É assim que, por fim, e já nos aproximando da data da primeira edição em dois livros (1580), Montaigne chega a conceber uma "nova maneira", que tanta originalidade dá à publicação e que assenta tão bem ao fidalgo cioso em não ser confundido com os pedantes "fazedores de livros", "maneira" que o levará a excessos, inclusive.

Já na avaliação da transformação da concepção de sua empresa, o comentador nota que, antes, partia dos empréstimos aos livros, ou seja, do discurso dos outros que alinhavava, e que, agora, parte de si mesmo, de sua "experiência pessoal". É a "sua vida habitual" que fornece os temas e solicita a reflexão. $\mathrm{E}$ a isso, somam-se suas observações sobre os que estão à volta. Há uma inversão no papel dos livros que, intervindo ainda, não fornecem a matéria, mas a ilustração de um pensamento pessoal de Montaigne, que apenas os folheia diletantemente, e não os estuda. Assim, interroga a vida, e o desenvolvimento dos seus escritos ganham o cunho de uma "conversação desembaraçada, pessoal, abundante". Consumada a transformação, o ensaio deixa de ser um "amálgama de exemplos e sentenças tiradas de um herbário e passa a um ramilhete de observações práticas, e de reflexões pessoais, ainda frescas e perfumadas pelo Eu de Montaigne". 
No entanto, essa "nova maneira" a que chega entre 1578 e 1580, adquirida, como procura mostrar Villey, no curso das leituras e acontecimentos, é hesitante ainda e como que um esboço do que virá a ser com o acréscimo de um terceiro livro. O comentador observa que esta primeira pintura do Eu assume três formas diferentes: (1) Montaigne pinta seu retrato (como em II, XVII, "Da presunção"); (2) nos expõe seus gostos, seu gênio, sobretudo nas Letras (como em II, X, "Dos livros"); (3) tira - e esse o traço mais proveitoso deles ensinamentos de ordem geral de suas experiências individuais, transformando em ideias a sua prática (II, XXXVII, "Da semelhança dos filhos com os pais"). O cotejo entre esse terceiro aspecto e o segundo é importante, pois assinala a passagem dos "ensaios do julgamento" aos "ensaios da vida", assim designados por Villey valendo-se de uma expressão de Montaigne, porque neles o ensaísta colhe os frutos de sua experiência. Um bom exemplo disso está consignado nas páginas do "Da educação das crianças" (I, XXVI), em que se condensa em ensaio a filosofia da vida, filosofia de sua experiência pessoal, implicada na sua pedagogia.

Publicado o livro em 1580, repassam-se as grandes experiências que Montaigne fará nessa primeira metade da década que se abre e que alimentarão as páginas do novo livro que será composto, levando dos primeiros esboços à tomada plena de consciência da forma da pintura do $E u$ e a conformação definitiva de uma filosofia totalmente compatível com a personalidade e temperamento do autor. Rememora Villey, nesse sentido, a viagem por estações de águas na Alemanha, Suíça e Itália, bem como o registro que nos deixou no 
Journal de Voyage; o exercício do cargo de maire de Bordeaux; as provações de 1585 (recrudescimento da guerra e peste grassando nos arredores do castelo de Montaigne; a fuga com a família).

Quando no início de 1586, volta ao castelo, Montaigne relê seus Ensaios, e diante da magreza e impessoalidade de muitos ("sabem a outrem os seus primeiros ensaios"), no intuito de corrigi-los e compatibilizá-los com a concepção de retrato a que chegou, introduz confidências nos primeiros capítulos. Mas o terceiro livro, escrito nesses dois anos, é que leva à perfeição a pintura do $E u$. A maioria, repara Villey, tira seu tema de alguma experiência pessoal ou de alguma particularidade de seu Eu. Segundo ele, "o que dá interesse [ao livro] invadido agora por toda essa experiência recente - será talvez a arte de precipitar as ideias que essa experiência contém por assim dizer em suspenso" (p. 50). Essa invasão da experiência pessoal é que dá sentido à expressão, do próprio Montaigne, de que Os Ensaios são "consubstanciais" ao seu autor.

Villey observa, porém, que os "pormenores demasiado pessoais" tendem a rarefazer-se, pois a pintura do Eu tem quase sempre "um alcance geral". Isso porque Montaigne "tomou agora plena consciência do que se pode chamar seu método", cujas exposições encontram-se nos capítulos "Do arrependimento" (III, II) e "Da experiência" (III, XIII). Esse o ponto talvez mais fundamental do desenvolvimento pleno ao qual Montaigne levaria a compreensão da sua empresa; pois, por trás de toda mobilidade do Eu (que o impressionava desde o início e que, sem dúvida, é uma visão que não abandona, continuando a vê-lo como "ondulante e diverso, em perpétua modificação"), o ensaísta descobre "um 
elemento estável, um núcleo permanente": "esse Eu profundo que podemos descobrir em nós, eis o terreno sólido sobre o qual edificar a nossa filosofia moral. O que assim estabelecermos não será levado pela enxurrada dos fenômenos" (p. 51).

Esse Eu, contudo, adverte Villey, não é facilmente que podemos generalizar suas experiências e fazê-las valer para os outros. Não há uma "lição" que se possa tirar das experiências desse Eu único, dessa personalidade que não é idêntica a nenhuma outra. As lições da experiência a que víamos Villey, há pouco, atribuir o cerne do interesse do terceiro livro, espécies de precipitados de ideias contidas em suspenso na experiência e extraídas dela, não fundamentam lições que edifiquem uma filosofia moral no sentido normativo exatamente, enquanto conjunto de regras e preceitos aplicáveis por qualquer um em certas circunstâncias. O "núcleo permanente" que Montaigne descobre, como uma natureza que emerge, em meio à variedade do costume, em meio ao que o hábito e as convenções acumularam no homem, não chega a ser um pólo de identificação com os outros homens, ainda que os aproxime, por alguma semelhança. "Embora os eus sejam todos diferentes, por algum lado se assemelham, pois 'deparamos em qualquer homem com o Homem'. Montaigne em se pintando, pinta também de certo modo todos os homens e cada um de seus leitores pode encontrar-se nele, aproveitar para si mesmo a pintura que seu autor faz de si próprio" (p. 51). Resta que nos explique, esse "certo modo" de aproveitar o retrato de Montaigne a todos. Teremos de esperar o lineamentos da "filosofia definitiva d'Os Ensaios" para obter uma visão um pouco mais clara 
do que Villey está sustentando, do que significa esse lado pelo qual todos se assemelham. Mas é inegável que uns sedimentos plutarquianos se depositaram nessa experiência que valoriza o traço privado e singular das ações mais banais e cotidianas, que denunciam a capacidade de conduzir ordenada e moderadamente a vida. Para Villey, eles despertaram o interesse de Montaigne por essa observação miúda de si e dos outros, com refinamento do reparo psicológico e da sondagem em profundidade dos móveis e intenções secretos das almas, o que combinava mais com um temperamento avesso às ambições e obrigações.

A comprovação de que Montaigne descobre um "alcance geral" do seu retrato ao aprofundar as experiências que expõe quando atinge "sua maneira" definitiva e mais madura, está no fato de que troca as desculpas que dava quando Ihe objetavam o caráter demasiado particular e sem relevância pública do seu retrato: não é um Xenofonte, nem um César retratado. Montaigne votava aos parentes e amigos, aos vizinhos o seu retrato, tirado com a pena, e pedia para ser lido num canto de biblioteca, em silêncio. Depois, cioso talvez de sua descoberta, desabusadamente aponta o contrário: "Apresento uma vida das mais vulgares, que nada tem de especial. A vida íntima do homem do povo é de resto um assunto filosófico e moral tão interessante quanto a do indivíduo mais brilhante; deparamos em qualquer homem com o Homem" (III, II, "Do arrependimento", apud VILLEY, ibid., p. 51). Também o apagamento progressivo dos "traços demasiado pessoais" o demonstra. 
Em 1588, vai a Paris cuidar da publicação de seu livro; é preso na Bastilha pelos da Liga, solto algumas horas depois por intervenção de Catarina de Médicis; encontra-se com Marie de Gournay, sua "fille par alliance"; passa por Blois, onde se reúnem os "États Généraux"; quase assiste ao assassinado do Duque de Guise. Volta ao castelo. Idoso e doente, não o deixará mais. Tudo isso nos lembra Villey, e observa que Montaigne "não renova suas experiências, não compõe outros ensaios". Apenas se dedica a povoar as margens de um seu exemplar da edição de 1588 em três livros com acréscimos abundantes, de caráter pessoal, em que a proximidade da morte e a convivência com a doença o incitam a voltar-se mais ainda para si. A natureza sociável cede o passo e convenientemente evita companhia e busca a solidão. Também acresce seus três livros com os frutos de suas novas leituras, o que o faz voltar involuntariamente, em parte, à maneira livresca do início, segundo o juízo do comentador. Mesmo assim, isso não faz com que o retrato seja negado em meio a essa sobrecarga e invasão de elementos estranhos. As citações dos outros, Montaigne adverte então, têm por fim fazer-se melhor conhecido.

Da mesma forma que - ainda na trilha de Villey - no início de seu trajeto, a primeira maneira de Montaigne decalcava o gênero Leçons e nele vazava uma filosofia impessoal, impregnada por Sêneca e o Estoicismo (sinalizando uma moral fundada em uma forte confiança na razão para vencer - num triunfo da tensão constante da vontade - as paixões, a dor e a morte, isto é, as adversidades e calamidades todas que o filósofo desafia e antecipa). Assim também, agora, passadas as lições de Plutarco, as leituras de Sexto que 
ensejaram a crise pirrônica, o ultrapassamento da suspensão do juízo em direção ao exercício de um juízo que ganhou consciência de sua originalidade (a originalidade do bom senso que preside seu exercício fundado numa docilidade aos fatos que constitui o principal resultado do seu ceticismo) pelo aprofundamento da experiência pessoal, Montaigne dá feição definitiva ao seu pensamento em moral. Aqui é um avesso que se descortina, quando se tenta levantar os frutos do trabalho da investigação montaigniana que se conscreveu no livro. Villey começa lembrando que, em matéria de filosofia moral o séc. XVI "evita perder-se nas querelas das múltiplas seitas" (p. 54): existem, lembra, como para um Guillaume Du Vair, duas escolas, a filosofia estoica e a filosofia da natureza. Estóica é a doutrina da impassibilidade e da contemplação desinteressada (Cf. p. 55), a qe pretende sprimir as paixões, afastando o Homem dos prazeres naturais. Já a filosofia da natureza, acolhe a natureza passional dos homens, "contenta-se em regular, em lugar de combater, os instintos que Ihe são naturais" (idem, ibidem). E Villey pode, então, completar: “ Se aceitarmos essa distinção que é a dos comtemporâneos, diremos que os Ensaios, partaindo da Filosofia estoica em 1572, chegam ao fim de uma longa investigação ao outro polo da filosofia moral, a filosofia da natureza" (idem, ibidem).

Acolher e moderar as paixões, temperar os prazeres, para melhor frui-los, submeter o próprio juízo à experiência, eis agora "o ideal moral de Montaigne": "conduzir a vida em conformidade com a condição natural" (Cf. p. 63). Trata-se de uma "moral de livre exame", que vem, diz Villey, substituir a "moral de 
autoridade" da Idade Média. Montaigne realiza "o sonho a que tendia confusamente o humanismo do Renascimento" (p. 71).

Seria, então, nesse ponto de chagada do percurso intelectual e moral do autor e seu livro que encontraríamos também uma forma inteiramente apropriada à 'Pintura do Eu': "À proporção que o Eu penetra no livro e em que Montaigne reflete sobre sua arte, a língua, o estilo, a composição (...) amoldamse progressivamente ao seu objeto" (id. ibidem). O que o Ensaísta reivindica é sua "forma natural" ("Falo ao papel como ao promeiro que encontro", III, 1; "A prosa que aprecio é uma prosa simples e direta, no papel como na boca; um falar (...) sem afetação, sem regra, livre, ousado ...", I, 26; e outras declarações mais), não deixando de, seguidamente, ostentar seu desprezo pelas regras.

Ora, é certo, lembra Villey, que a forma é cuidada e que não é mesmo difícil identificar alguns dos paradigmas de seus procedimentos, como Sêneca e Plutarco. Mas há um registro, continua, em que a maneira livre e 'sem regras', natural, se faz eminentemente efetiva (mesmo ao excesso, já que, segundo pensa, " a arte, o gosto nada têm a ganhar realmente com a desordem factícia a que seus preconceitos levaram por vezes o autor dos Ensaios", p. 76-7): o registro próprio da 'composição', com seus "saltos e cabriolas" (III, 9), cortes e interrupções, mudanças de direção, digressões, acréscimos ("o método de Montaigne nos últimos anos de sua vida", p. 77); enfim, a produção da 'desordem', a afetação do 'descosido'(cf. I, 26). É verdade que nesse texto negligente, sem plano e desígnios premeditados - o comentador lembra observação de Morellet - muitas vezes a ordem se manifesta; "há muitas vezes 
uma ligação com que se contenta o espírito" (p. 78). No entanto, é verdade também que muitas vezes "essa desordem que não é calculada, mas consentida por negligência, não serve mais á pintura do Eu" (id. ibidem), diz Villey. Os Ensaios não são descuidados na sua forma literária, mas sua negligência, sua desordem, certamente não aparecem aqui como uma forma apropriada de 'negligentia diligens'.

\section{b. A leitura de Friedrich}

Falemos agora da monografia dedicada aos Ensaios por Hugo Friedrich ${ }^{11}$. Lembremos que o livro é de 1949, mas sua tradução francesa só ocorre em 68. Estudo de fôlego que propõe uma síntese do pensamento de Montaigne, cujas formulações, pontualmente, ainda encontram eco e se fazem presentes em muitos estudos bem posteriores. Ela marca, paradigmaticamente, uma das tendências do comentário montaigniano: sem fazer abstração do gênero ensaio em que se desdobra o pensamento do autor, Friedrich está entre aqueles que buscam ordenar este pensamento em conformidade com um movimento "dialético" que conhece dois momentos: um primeiro negativo, de humilhação do homem; um outro, positivo e em dois tempos, de afirmação do homem. Esses momentos convivem na obra, pois não se trata de uma ordenação que respeite a ordem cronológica, o tempo da gênese. E, apesar de reordenar, por recortes parciais, o texto montaigniano, procurando reter sua "corrente profunda", este

${ }^{11}$ Friedrich, Hugo. Montaigne. A. Francke Verlag AG, 1949. Valho-me aqui da tradução francesa feita por Robert Rovini em 1968 e publicada pelas edições Gallimard. 
estudo não deixa de salientar a abertura desse pensamento para uma experiência múltipla, fragmentária, imprevisível e nunca acabada a que o gênero ensaio, invenção de Montaigne, dá plena expressão. Sigamos alguns dos seus passos, para nos familiarizarmos com as linhas gerais dessa interpretação.

Segundo o comentador, Montaigne ao compor os Ensaios acresce um elo a uma corrente de pensamento moral e antropológico que vem da Itália e se espalha pela França, a Espanha, a Inglaterra, e um pouco mais tarde a Alemanha. Trata-se do que Friedrich nomeia como uma "ciência moral moderna", que ganha sua mais elevada formulação em França, por este livro, apresentado como um "monólogo", em que se consignam as "livres considerações" do fidalgo bordelês, dentro de um espírito da Renascença de fins do séc. XVI. Essa fala solitária, redigida, relida e aumentada, é o fruto de trabalho que ocupou os últimos vinte anos de vida do autor, os do retiro a que consagrou sua "velhice". Nele se tratam todos os assuntos, de desigual interesse, mesclados às reflexões do autor sobre a conduta da própria vida, numa "desordem" e confusão que, à primeira vista, desorientam e só se vencem com a assiduidade na leitura. Isso porque, Montaigne metodicamente "não aborda os assuntos com desígnio deliberado", mas "se põe à escuta, deixa todas as coisas, mesmo as mais insignificantes virem até ele, e mantém, contudo, a certeza de que chega um momento em que elas se entregam e se ordenam, desde que saiba esperar" (cf. Friedrich, Montaigne, p. 11). Esse estilo que escapa às "definições tradicionais" está em relação com o "Ceticismo clarividente" do autor, que se define como um "olhar atento" que "respeita 
religiosamente a superioridade da pura aparência das coisas sobre sua interpretação prematura" (ibid.). Note-se que essa observação paciente e atenta dos fenômenos evita toda precipitação em interpretá-los ou extrair regras de validade geral a partir desses casos, orientando-se para o particular e individual.

Friedrich nota ainda o "encanto" dos Ensaios, que atraiu espíritos muito diversos, e assenta, sobretudo, em sua "agilidade de pensamento" e numa "maneira de falar". Um falar nonchalante que é "todo de qualidades plásticas, pleno de ironia, jamais patético, isento de toda fraseologia, o mais amiúde familiar e distendido, não sem grandes profundezas por vezes, mas despido de qualquer pretensão" (id., p. 12). Nesta fala, monológica, Montaigne mostra o quanto se sente à vontade diante da "universal contestação" e se presta de bom grado às "contradições" das coisas e às suas próprias. Além disso, não procura impor sua opinião, pedindo ao leitor apenas a escuta benevolente, não necessariamente a concordância, pois não tenta persuadir ou convencer de seus pontos de vista. No máximo, os convida à tentativa, à maneira própria de cada um, de fazer a mesma coisa, ou seja, de "ver claramente em si mesmos", reconhecendo aos outros o direito que ele mesmo Montaigne reivindica amplamente em seu livro de ser si mesmo. (ibid.).

A questão fundamental, prosseguindo sempre nos passos de Friedrich, a que Montaigne tenta responder em sua obra é "o que é o homem?". Ou melhor, de maneira mais exata e conforme a orientação do livro, é no plural que essa pergunta se formula mais adequadamente: "o que são os homens?". O que equivale a dizer que a empresa montaigniana se põe no campo de uma 
antropologia, filosófica, é claro, que se qualifica como "peça mestra da ciência moral moderna" (id., p. 13). Essa "ciência", esclarece, nada tem que ver com a "moral", e muito com os mores: estudo das condições concretas e variadas da existência do homem, dos "modos de vida e das maneiras de ser do homem, em sua pura realidade de fato" (imoral às vezes). Esses moralistas, a cuja linhagem Friedrich associa Montaigne, não são, como diz, "educadores nem professores de ética". São, antes, "observadores, analistas, pintores do homem" que se atribuem uma "tarefa infinita", aberta ao imprevisível dos futuros, à exploração dessa realidade vária no tempo e no espaço, dessa "complicação da natureza contraditória e da condição banal e concreta do homem" (ibid.). Estudo que só se torna possível quando se abandonam as pretensões normativas, porquanto essa "natureza" só se mostra quando a ética, em sua tarefa de educar e edificar o homem, "se retira para deixar o campo livre à observação não prevenida do real" (ibid.).

Dessa forma, afirma Friedrich, "os Ensaios não partem de uma ideia normativa da existência, tal como ela deva ser, mas de sua realidade, tal como é" (ibid.). Logo, estão fora do horizonte da obra o "sábio estoico", o "santo", ou qualquer outra "figura ideal" que se propusesse como "modelo absoluto" a partir do qual se pensaria a educação do homem. $O$ homem não deve realizar um modelo, percorrer a distância que o separa de um modelo de excelência ou virtude. Esse estudo se contenta em constatar como é o homem e em contentarse com o que ele é, em sua realidade complexa e múltipla. Nenhuma inquietação com o que ele deve "tornar-se", mas um grande interesse com o que 
ele é "comumente". Mesmo quando Montaigne recomenda, por exemplo, a cultura cosmopolita do seu tempo como um modelo, não o faz com "dogmatismo", mas de modo "liberal". Não se propõe como um modelo geral de conduta, pautado em uma forma única ou em um conceito genérico de humanidade que se deveria realizar.

Mas, o que o homem é comumente? O que descobre este estudo? Um homem de condição mediana, "cuja qualidade humana é a das infirmidades assaz humanas, uma criatura de uma surpreendente diversidade", que a civilização, com suas regras morais, sociais e políticas, só faz dissimular. O que este estudo visa descobrir é, precisamente, esse "homem mais rico do que os modelos ideais" a que quer a ética em suas pretensões que ele se identifique. Eis, como diz Friedrich, "a grande ideia dos Ensaios". A descoberta dessa riqueza do homem concreto leva a substituir um "conceito genérico de humanidade" pela "ideia de variedade, de individualidade, de diferença entre os homens" (ibid.). Daí as palavras-chave que compõem essa antropologia: "diversidade", "variedade”, "dissemelhança”. E sua orientação, não para a norma ou prescrição, mas para a "descrição". Orientando-se pela diferença, trata-se de "descrever a riqueza humana sob seus múltiplos aspectos no tempo e no espaço com tudo o que ela tem de individual em seus modos de existência, suas opiniões, seus humores, seus caprichos" (ibid.). Além disso, a descrição "mergulha" no que essa existência tem de "paradoxal e discordante". Não é que haja variação em homens de tempos e lugares diferentes; no mesmo lugar e tempo o homem é discordante; e mais, um mesmo homem é contraditório ao 
longo de sua vida. Vem disso a necessidade de não operar uma síntese prematura, o que se perfaz, evitando todo "remanejamento ou interpretação prematura que subordinaria o fato singular a uma síntese geral" (ibid.). Renunciando às "categorias grosseiras e demasiadamente vastas" com que operava a psicologia e a filosofia moral, a investigação montaigniana, "penetrada pela certeza de que nada de individual se subsume no geral", busca a "imagem", e não a "lei". O que torna também equívoco aproximar tal empresa da ciência experimental nascente e seu método, pois orientados para a descoberta de leis e a uma ordenação da experiência estranha ao projeto descritivo dessa "ciência moral", mais refinada. Daí, por fim, Friedrich qualificar o livro dos Ensaios como uma "fenomenologia moral", cuja expressão escrita, em sua "potência plástica", sabendo pintar "o traço único", coloca-o entre a filosofia e a poesia.

Dessa indagação geral sobre a condição concreta da existência dos homens, fica excluída, por incompatibilidade com o novo projeto que se esboça, a velha questão de saber o lugar e a função assinalada ao homem no "conjunto da ordem ontológica" (id., p. 14). Embora Montaigne fale em condição humana e mobilize a tópica cristã da miseria hominis, o faz somente com o intuito de rebaixar o homem. Para o cristão, ao contrário, a miséria do homem e seu reconhecimento é apenas um aspecto da condição humana. Expulso pelo pecado do orgulho da ordem da natureza e ingressando como pecador na ordem histórica, ele conhece também a perspectiva esperançosa do resgate e o caminho ascendente da salvação, desde que se empenhe e engage nessa via, operando em si, laboriosamente, uma transformação moral. Ou seja, o cristão 
conhece também uma dignitas hominis: criado por Deus, à imagem de Deus, o homem tem a possibilidade de ser resgatado e salvo. Montaigne, ao contrário, conhece apenas a vertente descendente da humilhação, que devolve o homem a sua "condição", reconhecidamente humilde. A função desses ecos da tópica cristã da miseria é justamente a de mostrar a via que leva ao "espetáculo da condição natural do homem" (id., p. 14). Uma vez descoberta essa condição, o homem é deixado como é. Montaigne não se interessa mais tanto pelo caminho da salvação, quanto pela dignidade sobrenatural do ser. E como, por indiferença em relação ao resgate, relaxa-se a tensão que se instaurava no homem cristão entre o pecador que ele é, e o que ele deveria realizar em sua peregrinação para salvar-se, pode-se explicar porque Montaigne desconhece a "contrição e o apelo à redenção" (ibid.). Montaigne, em suma, deixa o homem como está e, afirma Friedrich, "os Ensaios não são escritos para inspirar desgosto dele mesmo" (ibid.), pois "a mesma mão que abate, afaga e lhe mostra o que há de suportável nessa sua estadia no comum reino das criaturas da natureza" (id., p. 15). A perspectiva da finitude de que o homem sofre é aceita com a "serenidade e sabedoria" que, reconhecidamente, as páginas do livro demonstram. Aceita, então, a finitude como condição de existência a partir da desvalorização do homem pelas tópicas cristã e pagã, os Ensaios passam a uma "afirmação do homem", explorado curiosamente por essa fenomenologia descritiva.

Mas essa "afirmação" do homem não para na exploração da multiplicidade exterior dos mores, colhida na distância dos lugares e dos tempos, ou na observação refinada do outro. O projeto montaigniano, em sua vertente 
positiva, se perfaz, confinando ainda mais os limites de sua exploração. O objeto privilegiado dessa antropologia será, enfim, referido pela "figura que domina o livro": o seu autor mesmo, Michel de Montaigne. E a questão fundamental recebe uma formulação definitiva, com o projeto de autorretrato: "Quem sou eu?" (ibid.). Montaigne, que nisso poderia não sem alguma chance de erro ser aproximado dos autores das confissões e autobiografias, parte de um ponto comum a elas e ao seu livro: ele atualiza o preceito de Delfos, o "conhece-te a ti mesmo". Levando-o, diz Friedrich, ao pé da letra: "Montaigne estuda Montaigne" (id., p. 16). Desse estudo resulta "não um retrato com unidade acabada, mas uma pasta de esboços (carton d'esquisses) e de estudos como o pintor faz em diferentes momentos do dia, de diferentes posições, com diferentes luzes, ao acaso do instante vivamente traçado" (ibid.). Que não se pense, avisa imediatamente Friedrich, que o procedimento carece inteiramente de método. Há um "método rigoroso" que o preside: "método da sinceridade atenta que não diz senão o que pode garantir ser o conteúdo atual do eu (mol)" (id., p. 16).

Nenhuma facilidade nessa exploração da intimidade e nesse modo metódico de proceder e de expor. O centro do eu é difícil de discernir, e os contornos do eu são tênues e difíceis de demarcar. Há grande facilidade em cair na "falsificação de si", grande prontidão em supor para os atos falsas motivações. Há grande tendência, ainda, em facilitar as coisas "retomando clichês em vez de esposar a fonte sempre nascente de seu ser" (ibid.). Toda energia de Montaigne, afirma, é investida "em se encontrar, não em se inventar" (ibid.). Donde, note-se, o caráter de profunda ruptura com a literatura do tempo, 
cuja marca distintiva está em compor a partir de modelos e de preceitos, e recorrer ao artifício. A descrição a que Montaigne se dedica não admitiria artifícios, pois, se é como se descreve, falsearia todo o projeto e comporia somente uma máscara. E o trabalho recomeça sem trégua a "prova" (épreuve) que o indivíduo faz de si mesmo, já consciente de que não pode mais do que ter uma vista aproximada do objeto que visa, nunca sabendo exatamente "onde está e o que é seu eu" (ibid.). Como resultado, um retrato cuja linha interminável e contraditória é traçada de modo obstinadamente atento ao "momento fugidio", e que nunca se resolve em uma síntese definitiva, mas sempre se inclina às "imprevisíveis transformações" desse objeto movente que é o eu.

Montaigne se serve para cumprir o fim assinalado à obra de descobrir o eu, por um lado, de uma incontável massa de detalhes pessoais que registra no livro, e, por outro, de uma "forma de pensamento que se acantona deliberadamente na esfera das opiniões privadas e do gosto pessoal" (ibid.). Quanto ao primeiro aspecto dessa exploração do eu, Friedrich, reforçando uma vez mais a ruptura com a normatividade e a passagem a um projeto puramente descritivo, observa ainda que "Montaigne é o primeiro grande escritor da individualidade concreta", não mais se desviando dela pela necessidade, postulada pela ética antiga, de "perfeição moral", nem, segundo a ótica do pensamento e das atitudes cristãs, pela idéia de "pecabilidade". Já quanto ao segundo aspecto apontado, Montaigne, fazendo-se observador atento de si, como nota Friedrich, "permanece sempre à espreita de suas reações espontâneas", com o intuito de "desvendar sua constituição individual", falando 
das coisas e opinando sobre elas, não para mostrá-las, mas mostrar simplesmente o "alcance da vista", pois não está interessado propriamente em mostrar o que sabe delas, mas interessa-se por si mesmo. Porque para mostrarse e conhecer-se precisa operar sobre essas matérias, mantendo-se o espírito, todavia, atento a si mesmo nessa operação que o põe em movimento. Pode-se dizer, em suma, que examina matérias para examinar-se melhor, ver-se e dar-se a ver no ato do exame.

Essa mudança de foco, por sua vez, se explica pela situação histórica em que se encontra o ensaísta. Ela representa a descoberta de um terreno que permite sustentar a "pressão enorme da cultura" que, como que pesando por um lado, é equilibrada pelo "impulso antagonista da individualidade livre". Isso porque, no séc. XVI, o acúmulo desmesurado das matérias ensinadas, que cresceram com os aportes de estudos e aquisições eruditas, sufoca o que Friedrich nomeia o "princípio de ordem" que permitiu, nos primeiros tempos do humanismo, harmonizar "antiguidade e cristianismo". Desse crescimento resultou uma "polimatia caótica", uma "informe acumulação de saber", passível de ser dominada apenas pela "ousadia do indivíduo que reporta a si todos os teoremas, para Ihes dar lugar na organização de sua vida e de sua alma, ou para excluí-los sem fazer caso do respeito à autoridade" (id., p. 17). Dessa forma, os Ensaios são um livro em que ainda se acolhe uma riqueza considerável, mas, tais "tesouros" formam aí um "espaço arejado", no qual a individualidade pode mover-se e evoluir, descobrindo sua originalidade, embora 
permanecendo fiel à cultura, podendo dizer seu "parecer livremente" sem ser massacrado pela quantidade de saber.

Por fim, Friedrich faz notar uma última articulação. De um ponto de vista que poderíamos qualificar de teórico, o "retorno a si" que a obra montaigniana efetua, visa não só percorrer e conhecer os meandros do "profundo labirinto" que é o homem pela via única de acesso mais seguro e imediato a ele, mas também "aceder ao conhecimento da condição humana através de sua própria individualidade" (ibid.). O argumento, na verdade simples, é o seguinte: "se a individualidade é a verdadeira realidade da condição, é a análise de si que estabelecerá os liames mais estreitos com essa realidade" (ibid.). E ela o faz pela "experiência interior", que apresenta a vantagem de ser "imediata", quando o conhecimento "objetivo" é mediado. Essa "imediatez oferece ao analista de si a garantia de tocar a coisa viva" (ibid.). Portanto, essa "busca (quête) do eu" é o procedimento decisivo desse livro orientado para a descrição e destituído de pretensões normativas. De um ponto de vista prático e complementar, a "análise de si" empreendida nos Ensaios é, segundo Friedrich, acompanhada pela "resolução de levar a vida com toda autonomia, de ser homem desta maneira que Ihe fora assinalada, sem arrependimento, sem correção, não temendo senão a alienação de si” (ibid.). Assim, vê-se como esse corolário, digamos, prático da empresa aponta para o triunfo do próprio indivíduo frente ao alheio e às regras comuns de existência (no máximo, a um arranjo meramente pragmático com elas), de modo que, todo cotejo desse projeto com as "inteligências normativas de si" do passado se torna enganoso. Montaigne 
desconhece "forma essencial do seu ser, forma oculta, estabelecida por toda eternidade, nem evento central de sua vida em que essa forma se manifestou e realizou" (ibid.). É homem sem "crise" e sem "acme", sem abismos e cumes, conhecendo apenas o "fluxo contínuo em que mergulha vivendo e refletindo". Logo, nenhum projeto empenha o autor dos Ensaios a lançar-se na conquista de uma humanidade ideal que ele ainda não realiza. A matéria do livro é esse "fluxo", que se desenvolve sem mirar um acabamento ou perfeição e Montaigne tem, segundo Friedrich, plena consciência da inovação que propõe tomando-o por matéria.

\section{c. A leitura de Tournon}

A reconstituição do pensamento de Montaigne por Tournon ${ }^{12}$ nota, muito acertadamente, dois "eixos principais" nos Ensaios: o da ética e o da teoria do conhecimento (cf. Tournon, Montaigne, p. 145). Trata-se, por um lado, de

${ }^{12}$ Para a reconstituição breve da leitura de Tournon, não me valho de sua famosa monografia de 1983 Montaigne: la glose et l'essai, mas de um texto menor, publicado em 1993 na coleção "En toutes lettres" da editora francesa Bordas, e intitulado simplesmente Montaigne. Neste livrinho pequeno em extensão, porém grande em seus resultados - Tournon retoma e aprofunda as aquisições de sua tese, oferecendo uma visão de conjunto dos Ensaios, centrada na articulação entre o projeto do "auto-retrato" e o que o comentador chama de "uma ética inovadora", a cuja explicitação nos dedicaremos nas linhas a seguir. Utilizaremos em nossas notas a tradução que fizemos para o português: Tournon, A. Montaigne (trad. de E. Querubini), São Paulo, Discurso Editorial, 2004. 
mostrar que nas estruturas textuais dos capítulos e na invenção do ensaio se inscreve um projeto eminentemente crítico e emancipador, um modo de relacionamento com o saber, com a cultura depositada nas letras e com as autoridades, sobretudo antigas, nas quais o saber se acha explanado. Modo de relação que, embora incorpore e manipule os discursos alheios, não os endossa, nem arrasta consigo suas "cauções doutrinais", porque, precisamente, os submete a exame, interroga sua validade como lição. Essa incorporação e manipulação das matérias no livro faz-se de modo tal que do inventário não se pretende reconstituir um discurso conciliador e coerente. $O$ trabalho se concentra em tensionar as vozes do passado que vão sendo incorporadas ao texto, muito mais do que em compor, com a dose de devaneio ou fantasia que este projeto, humanista, continha, uma suma ou uma síntese universal dos saberes. Encena-se no texto um coro diafônico e o ensaísta se mantém distante, destacado como seus leitores, desses discursos variados a que dá voz.

Por outro lado, trata-se de apontar uma ética que se esboça, ou mesmo se formula, no livro, uma "filosofia inovadora" que nasce do cruzamento do "pirronismo" com a "prática do ensaio" e com a intenção afirmada de "regrar a própria vida" (id., p. 144). Tal ética se constitui como apoio e reforço reflexivo das propensões e aversões herdadas, naturais, o que significa "regrar-se". Uma escolha livre e lúcida vem substituir as determinações obscuras do atavismo. Como diz claramente Tournon: "Assim orientada, a iniciativa de Montaigne não é assimilável nem a uma pura descrição de si, nem a uma lição de moral. É uma meditação, no sentido exato do termo, na qual o pensamento se reapodera de si 
e se elabora pela escrita, sem falsificar os dados primeiros - "compleição" e condutas espontâneas - que assume" (id., p. 164). Podemos dizer que, aos olhos de Tournon, é ao mesmo que se chega pelo trabalho da reflexão. Parte-se de uma tendência cega, atávica, e chega-se à mesma tendência assumida livre e lúcidamente. Não importa decidir se a tendência (dado primeiro) era natural ou resultou de um hábito, instinto ou aquisição estável que se formou no processo educativo; importa torná-la consciente, no processo de reapropriar-se de si e de elaborar-se pela escrita, sem "falsificar os dados primeiros".

O trabalho do ensaio não opera uma transformação, mas antes uma confirmação dos dados primeiros. Portanto, tal trabalho consiste mais em dar forma a essa "natureza" ou "hábito" primeiros, do que em alterá-los de algum modo, mas sem reduzir esse trabalho a uma mera "descrição de si". Portanto, esse dado primeiro não é recusado. Poder-se-ia dizer que ele é reconquistado em sua pureza, talvez um pouco alterado pelo trabalho da reflexão, mas nunca negado. Dele se dá uma pintura em "cores mais nítidas" que as primeiras, eles ganham "um pouco mais de forma". O que se pinta: convicções, "humores", dúvidas. O que se nega propriamente: o que a cultura acrescentou de artificial e que encobria o natural; falseava o natural. Vestir-se com artifícios seria ainda negar esse natural. O que ele faria seria tão somente, pela escrita, "precisar os dados da experiência íntima" (id., p.147). "O ensaio é para Montaigne o meio de reencontrar seu ser natural por um difícil esforço de decantação e de elucidação" (id., ibid.). 
Tournon se interroga sobre o "tratamento da herança humanista" a que Montaigne procede. Lembra que a empresa montaigneana apresenta-se como "uma investigação que visa a recolocar em questão o catálogo das opiniões recebidas" (id., p. 85) Logo, Montaigne deve recuar dessas "opiniões para submetê-las à critica". E deve mesmo, no limite, desprender-se inteiramente delas e falar "tout fin seul" ("inteiramente sozinho"). Contudo, adverte Tournon, não se fala inteiramente sozinho no séc. XVI. A recepção de Montaigne sempre viu nele uma suma de sabedoria, onde reconheciam uma coletânea do saber herdado dos antigos. Embora a empresa tivesse por desígnio expresso libertar-se das vozes alheias (das "flores estrangeiras"), a pena do Ensaísta permanece cativa da "retórica humanista", refazendo as vias traçadas pela cultura, retomando seus "temas, formulações e problemas" (p. 86).

Quando a leitura se limita, observa Tournon, ao "inventário de materiais", é fácil encontrar antecedentes para os Ensaios. Isso vale inclusive para o projeto de submeter à crítica o saber transmitido, e Montaigne, consciente disso, às vezes se diverte, às vezes se irrita com essa cultura de empréstimos. No horizonte dessa relação com o saber do passado se vislumbra a figura do homem pedante.

Os Ensaios estão adornados de citações e empréstimos que são marcas visíveis de sua relação com a "Biblioteca universal". Relação ao mesmo tempo conflituosa e cúmplice, pois, como argumenta Tournon, o problema não poderia se reduzir a uma localização das fontes: os assuntos de meditação, as categorias morais e políticas, os conceitos metafísicos, tudo o que Montaigne 
utiliza e que se pode recensear faz parte de um fundo comum de cultura elaborado muito antes. Quando se extraem as "ideias" e se as classificam, diz Tournon, retirando-as "dos agenciamentos complexos nos quais entram em combinação com outros motivos" (id., p. 87), elas parecem banais, seja porque já haviam sido antes avançadas, seja porque serão repetidas pela idade clássica à saciedade. Daí Tournon, repassando o rol dessas ideias, colocar-se a questão: "Montaigne ter-se-ia limitado a se apropriar desta herança, a assumi-la, passando-a sob o crivo de suas escolhas pessoais, e dando aos lugarescomuns, por vigor ou desenvoltura de estilo, o acento da autenticidade?" (ibid.) E responde, lembrando o trabalho admirável de Villey, que durante um tempo acreditou-se nisso. O trabalho de Villey, recenseando as fontes dos Ensaios, tentou mostrar que, sob a influência das leituras, Montaigne evolui de um estoicismo inicial, passando pela crise cética e pela relativização operada pela leitura de Plutarco, teria chegado à plena consciência de sua empresa: um estudo empírico de si, de sua própria personalidade, que se resolve numa "filosofia da natureza" de cunho epicurista, fundando essa filosofia na “'experiência' cuja validade é garantida, ainda e sempre, pelos exemplos que fornecem tanto a história e a literatura, como a vida concreta" (id., p. 88). O problema está na imprecisão da noção de "influência" sobre a qual repousam as hipóteses de Villey, pois, pergunta-se Tournon, "que sentido podem ter, para Montaigne, os empréstimos e alusões aos escritores cujas proposições incorpora ao seu texto? Que significam as combinações e manipulações que opera sobre eles?” (id., p. 89). Para Tournon esta é uma questão preliminar 
fundamental que não pode ser ignorada se quisermos determinar o sentido dos Ensaios. Para resolvê-la, diz-nos, é preciso primeiro considerar os principais traços que apresenta a cultura da Renascença em fins do séc. XVI.

Tournon refaz, então, um percurso que leva do sonho de "sínteses universais" dos primeiros humanistas e seus projetos sincréticos de juntar filosofia antiga pagã e cristianismo, ainda viva em inícios do XVI, passando por um enfraquecimento progressivo desses projetos de conciliação e harmonização das vozes do passado, que acaba cedendo lugar à preocupação de precisar a identidade de cada uma, acentuando seus traços singulares, e chega mesmo ao reconhecimento de que se deve renunciar a toda síntese e contentar-se com uma acumulação desordenada de "observações disparatadas sobre fragmentos de textos" (id., p. 89-90). Exemplo que Montaigne segue à sua maneira. Como diz Tournon, ele "não se gaba de erudição" e "lá onde os autores de 'lições' procuravam conciliar, em pequena escala, restos de doutrinas [...] ele toma 0 partido inverso: aviva os antagonismos, faz trabalhar as tensões internas da cultura de que é tributário, para daí extrair problemas, objetos de meditação em vez de ensinamentos inteiramente acabados" (ibid.).

Exemplo de que procede assim, procura mostrar o comentador, ele nos dá mesmo quando pouco se afastou do modelo formal das "lições" de que partiu, no capítulo I, 1, que o comentador resume e lembra que, por ser colocado no começo dos 3 livros, indica já uma orientação. O que este capítulo faz, sustenta Tournon, "é perturbar a tipologia das atitudes e dos caracteres sobre a qual se fundam as receitas dos retores e os catálogos dos moralistas para 
indicar o que convém dizer ou fazer em tal ou tal circunstância" (id., p. 91). O capítulo em questão não mostraria somente a diversidade das condutas humanas, mas assinalaria "alguma desconfiança em relação às descrições sistemáticas, as teorias condensadas em máximas, as regras propostas como infalíveis pelos mestres do saber" (id., p. 92). Daí, poder Montaigne multiplicar as referências aos preceitos e exemplos que emprestou dos antigos e assimilou aos seus escritos, pois "ele se subtraiu antecipadamente a sua autoridade, e aos riscos de alienação que ela comportava" (ibid.), por essa atitude de desconfiança.

A "estratégia" demonstrada com a leitura do capítulo de abertura dos Ensaios carece, todavia, de generalidade. Não se pode pretender que a atitude de "desconfiança" em relação às "teorias" e "sistematizações" seja a constante dos procedimentos de Montaigne. Ela marca apenas uma "orientação". É preciso buscar no princípio de "organização geral do livro" a chave para compreender a sua estruturação e como ela nos "propõe uma perspectiva insólita sobre o mundo das ideias e dos homens" de grande discrição e, por isso mesmo, eficácia.

Para Tournon, "Montaigne reivindica uma irregularidade profunda para seus escritos", definida explicitamente pelo "princípio de organização do primeiro livro", no momento em que associa os Ensaios a uma espécie de "agenciamento" em que os capítulos aparecem como se dispersando na forma de "grotescos, esboços disparatados, abertos sobre prolongamentos, cuja complexidade torna imprevisíveis, proliferando no espaço como que para saturá- 
lo, mas sem limites claros, e sem outra lei que os caprichos da imaginação" (id., p. 94-5). De fato, sustenta Tournon, Montaigne sempre associa à novidade e originalidade de sua empresa, traços de excentricidade ou bizarria. Isso fica claro quando, já tendo formulado o propósito de "apresentar-se como tema e como assunto" de seu livro apresenta-o em "Da afeição dos pais pelos filhos" (II, 8) como "fantasioso e tão distante do uso comum". Também quando, muito antes de formular o projeto de autorretrato, fala de sua empresa de escrita associando-a a um simples "registro" das "quimeras e monstros fantásticos" que um espírito ocioso, sem assunto fixo e prescrito, acaba por engendrar.

Tournon, sem reduzir, todavia, os Ensaios a um "repertório de fantasmas" produzidos pelo ócio e a melancolia, e sem ver também nestas "afirmações desconcertantes" as velhas "desculpas de alguma modéstia de convenção", procura levar a sério as metáforas do monstro e dos grotescos. O que entende nelas é a imagem da "errância" que comenta, num cotejo com outra espécie de discurso, em termos que vale reproduzir: "Em um discurso regular, os pensamentos se encadeiam, se corroboram, e o sentido do trajeto textual, das premissas à conclusão, os disciplina, unificando-os. Inversamente, as fugas de um espírito 'fantasioso' criam híbridos e 'monstros', mesmo com materiais de conhecida banalidade, se são reunidos a despeito do bom senso" (p. 94). Assim, a "estrutura da coletânea" de textos que passa, em suas "fugas", "de uma ideia a outra, de um assunto a outro, 'sem ordem e sem propósito"' marca a "singularidade" desse livro que opera "combinações insólitas de motivos", sem que estes isoladamente deixem de permanecer "quase conformes aos modelos 
correntes". São fragmentos híbridos, acolhidos para exame, sem nenhuma pretensão de "recompor um corpo sistemático, ou reduzir-Ihes os disparates".

Isso determina as condições para "multiplicar as reminiscências literárias", pilhando e remendando "retalhos heterogêneos" (sentenças, anedotas e exemplos), e no mesmo movimento fazendo-os "perder suas cauções doutrinais". Montaigne está pouco preocupado com restituir a "coerência" às alegações, como o estavam um Du Vair ou um Justus Lipsius; ele apenas "cita opiniões destacadas dos discursos que as caucionam", aplicando como critério de escolha o valor próprio dos fragmentos ou sua aptidão para se deixar anexar. Não se preocupa em reter seus antecedentes, nem seus corolários. Além do mais, o uso que faz de máximas e de exemplos, frequentemente, distorce-os e desvia-os de sua significação de origem.

Até aqui, a reconstituição do pensamento de Montaigne por Tournon que estamos acompanhando não fez mais que considerar "seus materiais ideológicos", seus empréstimos e elaborações, e o "tratamento por que passam". É preciso consideram ainda os "princípios das manipulações operadas" sobre esses materiais.

De fato, observa Tournon, isso que foi dito até agora, não é muito diverso da recensão de ideias ou comportamentos, com o intuito de julgá-los e submetê-los à crítica. Não é muito mais que "rotina de moralistas e filósofos". O procedimento de Montaigne é diferente. Nele se combinam a atitude normativa de um juiz ou moralista com a de uma testemunha curiosa. Por isso, muitos críticos viram que, nos Ensaios, Montaigne fazia despontar uma "atitude de 
espectador, de si e dos outros", e sua obra já ia como balizando uma "psicologia descritiva", em que o conhecimento de si abandona as "finalidades normativas" que a ele prendiam os antigos. Mas tal entendimento levou a atenuar ou apagar suas "fórmulas de exortação" e suas "advertências". O estilo dos Ensaios, não é jamais "neutro". Os dois aspectos estão presentes e não podem ser apagados. E a tentativa de decidir entre o "moralista" que faz passar "conselhos por constatações" e o "observador indiferente" que experimenta o estilo do "pregador" não resolve a questão. Os enunciados, formulados seja no imperativo, seja no indicativo, não auxiliam na determinação da "atitude de Montaigne". É preciso compreender como se dá a combinação desses "tipos de enunciados" nos capítulos, para entrever essa atitude que concilia o aspecto normativo com a psicologia descritiva.

Para dar uma ideia dessa "combinação de linguagens", Tournon resume as linhas gerais de um capítulo em que flagra o princípio que governa essas manipulações sobre os materiais (discursos) que compõem o livro. Tratase do capítulo I, 14, "Que o gosto dos bens e dos males depende em boa medida da opinião que temos deles". Desde o título, o propósito assinalado ao arrazoado parece ser, simplesmente, a demonstração de uma tese acerca da relatividade dos bens e dos males. Como todo evento não depende senão do juízo que cada um formula acerca dele, caberia àquele que o experimenta darIhe outro "gosto". As coisas mesmas são, ao que parece, indiferentes. Montaigne o demonstra aplicando o modo cético da "relação": há uma diversidade de opiniões acerca de cada coisa demonstrando que a realidade delas suscita em 
nós reações diversas. Nenhuma dificuldade, para prová-lo, em acumular exemplos e argumentos dessas reações diversas diante das paixões, da dor, da morte. Tudo, por um lado, compõe "um espetáculo [...] oferecido à curiosidade do leitor". Por outro, são exemplos "no sentido normativo": sentenças, comentários de aprovação, apóstrofes com valor de exortação, máximas, exemplos de resistência a imitar, em suma, preceitos e modelos de virtude alinhavados por Montaigne, com o intuito de demonstrar o que já se insinuava no título. A conclusão, porém, como o faz notar Tournon, "modifica tudo", pois assimila o conjunto dos discursos sustentados a uma "farmacopeia" composta de drogas de virtude diferentes "dentre as quais cada um escolherá aquela que convém melhor ao seu "humor"' (id., p. 103). A "verdade intrínseca" das receitas propostas conta pouco. Relativos não são somente os bens e os males, objeto de consideração até aqui, como parecia prometer o título. São também os "discursos" variados que tentam convencer homens de "temperamentos" diferentes a viver em meio aos bens e aos males. "Como se o valordas máximas filosóficas, arremata Tournon, 'dependesse em boa parte da opinião que temos delas', ou da predisposição que temos em adotá-las". Tranfere-se a lição de relativismo para os textos que vinha examinando. Sem renegar o valor desses "argumentos e exemplos", que retira, no capítulo em questão, em boa parte de Sêneca, Montaigne formula-os em seu próprio nome, permanecendo, contudo, na posição de um receptor, como nós leitores, ouvindo os discursos que acabara de formular. Ouvinte interessado, diga-se, pois "busca o que melhor o ajudará a 'manter a alma e a razão em equilíbrio". Mas, ao mesmo tempo, "reticente" 
diante dos "discursos ditados pela filosofia" e escorados pela "história" e pelos exemplos do mundo.

Assim, conciliando a linguagem normativa do moralista com as observações de um espectador indiferente, Montaigne "se exprime como juiz e testemunha das fantasmagorias do sofrimento e da coragem". Eis sua "posição instável", tornada possível e construída no capítulo examinado a partir de um "desdobramento" entre "a palavra proferida" (tomada ou não a outrem) - a que Montaigne de algum modo quer prender-se ou aderir - e a "reflexão que determina o seu uso" - ato, inversamente, que o mantém destacado das proposições que escrevera. Tudo se passa - tenta mostrar Tournon - como se a escrita dos Ensaios funcionasse como um espelho em que se refletem os dramas internos do teatro da "meditação". Por isso, essa escrita é qualificada de "especular". Entram em cena, "o preceito e o exemplo ilustre". Os enredos desses dramas são oriundos de uma "memória coletiva do humanismo" que Montaigne frequenta, mas não imediatamente endossa. $O$ "sujeito pensante permanece em contracampo, imperceptivelmente deslocado, atento ao que the vem sob a pluma". Não adere, pode-se dizer, mas também não é um simples espectador curioso das "dores e sofrimentos".

Estamos falando de uma 'atitude' diante do saber e da autoridade que compõem a herança. Atitude que permite usar a herança sem a ela se submeter docilmente, sem correr o risco da alienação. Não se entrega ao outro facilmente. Não se deixa levar ou guiar pelos outros. Quer pensar por si mesmo e ser 0 artífice de suas próprias escolhas. E usa a herança sem intenção de edificar, de 
instruir. As opiniões do passado, mesmo as mais reputadas, são examinadas. Ao que parece, a postura descrita casa bem com o que se apresenta como sendo a atitude daqueles que, no diálogo, examinam uma matéria, repassando as opiniões contraditórias que sobre ela se sustentaram, sem fazer caso da autoridade e do renome de quem sustentou essa ou aquela opinião. Dialética. Sistema, teoria, regra, preceitos, exemplos, doutrinas, nada tem validade de antemão. E o diálogo pode mesmo não chegar a nenhuma resposta sobre a questão examinada. Pode ficar na aporia. Não se endossa uma doutrina de antemão, venha ela de uma ou de várias fontes.

Vê-se, então, que a leitura apontada não deixa de ser, aparentemente, muito similar ao que se preceitua tradicionalmente. Não se percebe ainda claramente em que ela se destaca de um dos pontos fundamentais do legado, de uma das lições fundamentais da cultura antiga. Em ética e mesmo em questões de retórica e poética: a da imitação rival de autoridades. E a rearticulação bastante engenhosa das matérias de que dispõe e a partir das quais constrói seu discurso. Porque não se trata de acatar pacificamente ou respeitar servilmente suas lições e preceitos nessa cultura.

Contudo, a imagem que aqui se cria da cultura retórica da Renascença parece insuficiente. Ela se presta a criticar aquilo que, no interior mesmo dessa cultura, era criticado: a má afetação, a imperícia (estranha a ideia de um vir bonus dicendi peritus). Reduzir a cultura da retórica ao seu desvio vicioso (pedantismo), opor em bloco essa cultura da imitação servil ao nascimento de uma cultura de livre pensamento e crítica, não escamoteia os 
dados do problema? O mesmo se diria da tradição do pensamento moral pagão e cristão. É como tomá-los por ingênuos, por aceitarem ideias como modelo, autoridade, preceito, conselho, em matéria moral e artística, em nome de uma ideia de crítica e de originalidade estranha ao tempo.

Afetar com um valor negativo toda a sabedoria veiculada pelas máximas, pelas sentenças, pelos exemplos, desvalorizando, ou pelo menos desconfiando do valor dessa sabedoria, não é desconhecer ou desconsiderar o que ela tinha de inventivo, embora se fundasse na tradição? Ruptura demasiado radical, no nosso entender.

O que move esta leitura é uma ideia de ruptura com as práticas de letrados e de filósofos do tempo, que apaga traços importantes do pensamento montaigniano, no que diz respeito ao discurso e à orientação das ações. Não fundar a inventividade no que nunca antes foi feito ou dito. Não se trata de tirar do fundo do nada o novo, ou de escolher e agir de tal modo que nenhuma regra, natural ou convencionada, oriente a retidão. Porque seria apostar em uma "autonomia" plena e incondicional, que mais do que não seguir regras externas, dita regras e as põe enquanto tais no ato mesmo de agir ou produzir algo. Não seria mais adequado pensar que Montaigne, em conformidade com as letras do tempo, censura modos enrijecidos de aplicação de regras, como se fossem receitas prontas, que não consideram a ocasião do seu uso? É claro que a prova principal de que Montaigne obedece a regras estaria em apontar os passos dos Ensaios em que a elas obedece efetivamente. As transgressões devem ser pensadas tendo por referência igualmente a regra transgredida e o motivo ou 
razão da transgressão: motivo mais alto, por isso, obediência a uma "conveniência" mais imperiosa. Logo, é preciso pensar, em alguns casos, em um conflito de deveres, mas nunca na negação desse horizonte regulado de atuação em que opera a efetuação do pensamento e da escrita. Mas, para além dessas provas pontuais, poderíamos apontar a presença de conceitos-chave do pensamento retórico: prépon, firma facillitas, convenientia ou decorum etc., na produção do "natural" montaigniano.

Além disso, recusar essa hábil capacidade de lidar com os códigos em nome de uma liberdade excessiva de opinião, no séc. XVI, obscurece 0 interesse político dos escritos, pois ao invés de notar o modo discreto como se interfere nas questões do tempo, e se aconselha sobre elas, dá-se ao texto um caráter de recusa radical das "ideologias" e o improvável traço de proposta de uma ética da autonomia e da fidelidade a si. Isso teria como efeito, no máximo, acentuar o caráter insólito e extravagante dos escritos, e a inscrever seu interesse no âmbito privado que Montaigne aponta para eles na advertência "Ao leitor". Mas, levar ao pé da letra essas formulações, sem ver nelas estratégias para captar a atenção dos leitores e a construção de uma posição em que está autorizado a falar a muitos, com liberdade sim, de assuntos mais ou menos graves, sem oferecer simplesmente uma opinião com caução estritamente pessoal, fruto de seus estudos e experiência. O "meu" em oposição ao "alheio", sem mais. Basta ver como Montaigne, na maioria das vezes, reencontra opiniões reputadíssimas, que cita em corroboração às ideias que vem expondo como pessoais e puramente suas. Estratégia habílima de ombrear com as 
auctoritates, invertendo o jogo tradicional em que se parte delas como premissa para sustentar alguma tese e se faz com que o discurso próprio as encontre pelo caminho e com elas coincida, como que por acaso, confirmando o que antes já se pensava. 


\section{PARTE 2: O ENSAIO: O ARTífice e A OBRA}

\section{O artífice: a instituição do ensaísta}

De uma leitura demorada, rigorosa e atenta d'Os Ensaios, entretanto, firma-se uma convicção sobre a unidade e regularidade bastante fortes, latentes sob um conjunto de discursos muito ricos e diversos em matéria abordada e em circunstâncias de escrita, bem como muito "desenvoltos e livres" em sua disposição e em sua elocução. Embora a análise de cada capítulo e a comparação entre capítulos nos convide a um mergulho na variação, e Montaigne em pessoa confesse o gosto acentuado por ela, é patente, para quem os lê com cuidado, que uma mesma "cabeça" e "mão" os desenvolve e amarra com grande "suficiência" e pertinência, não obstante se possa notar, como de fato se notou, que a firmeza dessa mão e a pertinência e propriedade dessa cabeça variaram ao longo do tempo e da composição dos livros. Para apoiar essa convicção nem precisaríamos recorrer ao dado biográfico e histórico de que seguramente dispomos, revelado pela sequência das edições que foram sendo preparadas, modificadas e acrescidas por Montaigne nos últimos vinte anos de sua vida, anos posteriores ao "retiro" em que o Ensaísta se dedica, não sem algumas interrupções, à confecção de sua obra. A informação preciosa que nos aporta o "Exemplar de Bordeaux", com sua multiplicidade de acréscimos e correções, e o cotejo com as edições anteriores que felizmente chegaram a nós nos afiança o afeto por esse filho concebido na relação com as Musas, ademais confirmado expressamente pelo seu autor mesmo em vária ocasião no próprio livro. 
Mas não cabe aqui ficar numa mera impressão de leitura, nem tão só no dado histórico e biográfico. É preciso adentrar o domínio das concepções e da maneira recorrentes e constantes para demonstrar, com alguma verossimilhança, o que esse efeito de unidade na recepção pela leitura, quase impressionista, mesmo em meio à quase vertigem que o discurso copioso e aparentemente irregular nos aporta, já nos parece mostrar. Numa primeira aproximação, há de se observar, então, assumindo talvez a entrada mais óbvia ao universo das concepções dos Ensaios, sua relação com as fontes e com a recuperação dos valores e normas do mundo antigo, greco-romano, posto na ordem do dia pelos vários projetos intelectuais da Renascença. Em França, como se sabe, pelo menos desde os tempos em que Francisco I, o Pai e Restaurador das Letras, ambienta, fomenta e promove os Studia humanitatis, na primeira metade do séc. XVI. Uma educação humanista se concretiza, no caso específico de Montaigne, não só na primeira educação especial providenciada pelo pai e no ingresso ao colégio de Guienne, mas também pela atividade de magistrado exercida posteriormente, bem como pela amizade cultivada por La Boétie, moldada pelo modelo de amizade transmitido pelas Letras da antiguidade. Boa parte, portanto, da "infância" montaigniana se passa sob a influência desse ambiente de restauração do saber dos antigos. Interessa, porém, de modo mais preciso averiguar a especificação propriamente montaigniana de reinstaurar a Humanitas, sem grande preocupação em estudar como ele participa desse movimento mais geral do tempo. Interrogar a sua concepção, por assim dizer, madura e consciente, professada e praticada no 
livro. Aqui o mergulho no discurso montaigniano valerá mais que uma exposição panorâmica para corroborar a tese de que Montaigne se filia a ideias em voga. É dificílimo negar, é mesmo, no meu ver, incontestável, que um livro que dá tamanha centralidade ao homem, como o fazem os Ensaios através do seu projeto de autorretrato, no cerne do qual está inscrita de modo indelével a máxima de Delfos, e que com tamanha minúcia trata, não do Homem, mas de um homem, não faça desse ser mortal, particular e privado, uma concepção bastante elevada e em franca ruptura com o tópos da miseria hominis medieval. No entanto, em Montaigne as coisas são sempre muito mais matizadas e com contornos nem sempre claros. Pois, é inegável também que a concepção que o livro nos aporta num outro movimento aposta sempre nessa outra máxima, inscrita igualmente em Delfos, e que lembra a mesma mortalidade do homem e exige dele a "moderação", rebaixando suas expectativas. Portanto, o humanismo montaigniano, bem considerado, tempera uma elevada atenção dada ao homem com a adequada postura que adverte contra toda hýbris, isto é, contra os arroubos - de consequências éticas, políticas, religiosas, nem sempre bemvindas e muito visíveis no momento histórico em que escreve - de uma excessiva confiança em si. Não esperemos encontrar, então, nos Ensaios, nada parecido com um Discurso sobre a dignidade do homem, a maneira de um Pico de la Mirandola. Mais frequentemente se lê a advertência que devolve o homem ao seu lugar entre as criaturas, não no topo de uma hierarquia de seres e em relação privilegiada com Deus, mas misturado um tanto confusamente a elas, discernindo, porém, com juízo certeiro o quanto de dignidade cabe a essa figura 
e quando o excesso, presunçoso, se insinua em sua avaliação em prejuízo do próprio homem.

Essa é uma imagem, válida, mas ainda vaga, da riqueza de minúcia com que o homem é tratado no interior da obra, em toda a sua... a tentação é dizer: imperfeição; bem ao contrário, pode-se corrigir a expressão e dizer: em toda sua capacidade de fazer florescer, voluntariamente e dentro dos limites das possibilidades humanas - o que implica um uso lúcido da razão e do juízo -, não um anjo, nem um Catão, mas igualmente, não uma besta, e sim um homem. No intuito de estudar em detalhe essa imagem, talvez seja adequado perguntar pela configuração que assume a relação com o passado das Letras e com o valor depositado nelas para a construção da Humanitas segundo pensa o nosso Ensaísta.

O mais óbvio, então, é começar pelo que mais salta aos olhos de quem folheia os três livros dos Ensaios: a verdadeira enxurrada de referências, explícitas ou implícitas, aos clássicos romanos e gregos. Temos boa consciência, desde os trabalhos de P. Villey, da prevalência de certas leituras, e do impacto delas, em momentos bastante precisos da feitura e escrita dos Ensaios. Mas do próprio Montaigne colhemos a confissão de dois dos seus autores favoritos e mais frequentemente lidos e compulsados: Sêneca e Plutarco. Dos dois, permanecem nos Ensaios talvez como marca universal deles um conjunto de problemas e temas - certamente, não exclusivos deles, mas pertencentes a um fundo comum de cultura ético-política, herança da Antiguidade - que insistentemente se abordam e se repassam e se repisam, e 
também, talvez no caso do segundo, um certo estilo herdado de tratar a problemática moral, que restaria qualificar. Claro está também que não é de negligenciar a presença de Sexto Empírico não só certamente na Apologia de Raymond Sebond, mas também se espraiando com sua crítica do conhecimento e da razão por quase todos os capítulos, compondo um fundo cético a partir do qual os arrazoados montaignianos se desdobram. Nem se pode desprezar a enorme presença de um Horácio, de um Lucrécio, abundantemente citados; de historiadores como Tácito, Títo-Lívio, e da crônica mais próxima de seu tempo, inclusive os relatos dos viajantes do Novo Mundo; de Cícero mesmo, e, no terceiro livro e em acréscimos do "Exemplar" a presença crescente de Platão e junto com ela, a proeminente figura de Sócrates e de seu saber "negativo". Trata-se de uma maneira de interrogar e discorrer a partir de premissas reputadíssimas que o conjunto dos Ensaios às vezes assume, às vezes questiona, sempre falando a partir de um quadro posto pela tradição em que eles se inserem e a partir da qual instauram seu discurso, não, certamente, com o intuito de demonstrar uma verdade objetiva sobre as coisas, mas, antes, de exercitar o julgamento por ocasião das várias matérias que se examinam e frequentes vezes, de determiná-lo, ou seja, de assentir ainda que provisoriamente a um resultado desse mesmo exercício, e julgar. Trata-se, por outras palavras, de dispor de um conjunto mesmo de modelos de pensamento e escrita, disponíveis para a imitação, onde se fez a instrução e de onde se extraem ou no qual se entroncam as discussões e considerações do fidalgo francês. Voltaremos a isso. Por ora, não vale a pena insistir no rol das 
referências relevantes, que seria imenso, mas estudar, desde já, não a prevalência de um ou outro, mas o modo como, em geral, Montaigne se posiciona em relação a todos. Isso nos obriga a uma avaliação do processo pedagógico que institui o que, no livro, se nomeia uma teste bien faicte.

Esse o passo primeiro e mais seguro para o exame que se empreende da conformação do ensaio: olhar de bem perto como se pensa a educação do homem, educação responsável pelo desenvolvimento da potência (dýnamis) própria do ensaísta, de que o ensaio é obra (érgon). Ora, para dizer desde já o essencial, a institution montaigniana é pensada a partir da oposição onipresente e forte nos Ensaios entre o próprio e o alheio, com formulações que avançam em uma "licença" em relação aos clássicos que deveremos interrogar com cuidado, sob pena de conferir a Montaigne uma concepção já muito moderna de se relacionar com o passado, suas doutrinas e ensinamentos, e em franca ruptura com eles. Incorrer em tal risco se torna tanto mais fácil, quanto mais se enfatiza a presença, inegável, do Ceticismo de Montaigne. Que dogmas permanecem de pé, que lições do passado continuam válidas, que escola de pensamento mantém suas pretensões de verdade e certeza sobre o mundo e sobre o homem, diante da diatribe cética que destrói desde a base os frágeis conhecimentos que a razão humana alcança, e solapa a própria razão? Montaigne já não seria, antes de tudo, um autor que despreza todo saber constituído antes dele e reclamaria uma total liberação dos dogmas antigos e mesmo qualquer certeza quanto aos dogmas cristãos? Por ora, pode-se adiantar que a posição que se assume aqui, bem ao contrário, aposta que a pista para a 
constituição da vis própria dessa teste bien faicte, de que a dýnamis antithetiké dos céticos é uma componente, corre através da profunda "assimilação" e "apropriação" das lições contidas, seja nos livros, seja na própria experiência. E não só a sua constituição, mas o seu efetivo exercício permanece ligado ao contínuo "comércio" e "diálogo" com as fontes reputadas do passado, suas proposições e problemas, embora, em última análise, o estatuto dessas proposições e teses seja inteiramente transformado pelo Ceticismo. Portanto, esse conjunto de lições conserva sua legitimidade, apesar da crítica cética, e apoia o exercício do julgamento no terreno móvel em que ele se move: o da contingência radical das ações humanas assaltadas pela inconstância da Fortuna e do próprio homem. Certamente, daquele estatuto e da experiência teremos muito mais a falar, e também dos desempenhos, na conversação e na escrita, dessa vis. Por enquanto demos atenção aos termos mais gerais e formadores dessa "disposição", ao mesmo tempo intelectual e moral, e sobretudo atentemos para a sua relação com a experiência do mundo a que a criança deve ser exposta e a sua relação com o estudo das Letras e Ciências. Em termos montaignianos, começaremos estudando esses dois "comércios": a frequentação mundana e a "conversa" com aqueles que apenas moram na memória dos livros.

Há dois lugares privilegiados nos Ensaios em que se tematiza a institution, embora o tema reapareça com frequência por toda obra. Dois capítulos seguidos do primeiro livro e em explícita continuidade um com o outro: Du pedantisme (I, XXV) e De l'institution des enfans (I, XXVI). Por ora, atenho-me 
aos passos e formulações fundamentais do segundo para o meu propósito aqui, que é o de mostrar o modo como se concebe a educação de um menino fidalgo, pois se trata patentemente disso, bem como o relacionamento com as auctoritates do passado que se vai delineando nessas páginas e sua participação na formação da capacidade de julgamento, sem pretender, pois, examiná-lo em toda sua extensão e profundidade.

\section{a. A educação da suffisance}

O De l'Institution des enfans apresenta-se como uma carta endereçada por Montaigne à condessa de Gurson, Madame Diane de Foix, então grávida, em que a aconselha sobre o que entende ser e como deve ser desempenhada a tarefa em que está posta "la plus grande difficulté et importante de l'humaine science", isto é, "la nourriture et institution des enfans" [ A maior e mais importante dificuldade da ciência humana; a criação e educação das crianças] (I, 26, 149): a educação das crianças. O texto abre-se com considerações pessoais, incluindo observações sobre a própria obra e sua relação com as ciências e letras, já dando indícios dos temas que se desdobrarão. A dificuldade central da tarefa que o texto parece querer atacar incide no lugar reservado à ciência na educação de uma criança e no tipo de relação que com ela se deve estabelecer.

Depois de encarecer a dificuldade da tarefa de educar, ao tentar definir a que rota se deve encaminhar uma criança, devido a tênue informação que se pode obter das manifestações de suas inclinações em pouca idade, e 
diante do risco de ocupá-las longo tempo com coisas nas quais não conseguirão sucesso, Montaigne esclarece que "[s]on opinion est de les acheminer tousjours aux meilleures choses et plus profitables, et qu'on se doit peu appliquer à ces legières divinations et prognostiques que nous prenons des mouvemens de leur enfance" [sua opinião é a de encaminhá-las sempre para as coisas melhores e mais proveitosas, e que pouco devemos nos empenhar nessas levianas adivinhações e prognósticos que extraímos das iniciativas de sua infância.] (id. ibid.). Continuando, portanto, sem se fiar nos prognósticos e adivinhações frágeis que os pequenos dão de seus talentos e engenhos, Montaigne esclarece de saída o papel que reservará à "ciência":

“[A] Madame, c'est un grand ornement que la science, et un util de merveilleux service, notamment aux personnes élevées en tel degré de fortune, comme vous estes. A la verité, elle n'a point son vray usage en mains viles et basses. Elle est bien plus fiere de préter ses moyens à conduire une guerre, à commander un peuple, à pratiquer l'amitié d'un prince ou d'une nation estrangiere, qu'à dresser un argument dialectique, ou à plaider un appel, ou ordonner une masse de pillules."

[Senhora, a ciência é um grande ornamento e uma ferramenta de admirável utilidade, sobretudo para as pessoas criadas em tal grau de fortuna, como vós o sois. Na verdade, em mãos vis e baixas ela não tem sua justa utilidade. Orgulhase muito mais em ceder seus recursos para organizar uma guerra, comandar um povo, conquistar a amizade de um príncipe ou de uma nação estrangeira do que em estabelecer um argumento dialético, ou em defender uma apelação, ou em receitar um amontoado de pílulas.] (id. ibid.) 
Não se trata de recusar a ciência, bem entendido. Mas de reservar-Ihe um papel de "instrumento" a ser manejado por pessoas de alta fortuna. Seus meios prestam auxílio aos generais, príncipes e reis, conselheiros de príncipes, embaixadores. Os desafortunados, mãos vis e baixas, empregam-na na disputa dialética, no pleito advocatício, na medicina. Não há negar a afetação dos preconceitos do fidalgo em relação aos ofícios servis. A ciência é melhor empregada nas ocupações liberais e a servem. São argumentos constantes na pena do Ensaísta. Poderemos ler a mesma coisa, em formulações levemente variadas, no capítulo sobre o pedantismo que antecede o De l'Institution, ou no capítulo sobre a conversação, no terceiro livro. Representa, mais do que um preconceito exatamente, um traço do éthos aristocrático que reclama e de que se investe amiúde nas páginas do livro o seu autor.

Como Montaigne crê que a condessa a quem se dirige não esquecerá das ciências na educação dos seus filhos, já que pertence a uma casa cujo passado conheceu muitos letrados, endereça uma ideia (fantasie), contrária ao costume, no que respeita a esse ponto específico: "je vous veux dire là dessus une seule fantasie que j'ay contraire au commun usage" [quero dizer-vos aqui uma única opinião que tenho contrária ao uso comum] (id., 150). De fato, o texto recomeça restringindo o advis a uma parte, do todo de que se comporia o "encargo do preceptor" (charge du gouverneur), e explicitando os fins a que deve visar essa educação bem como o tipo de preceptor que a ela se presta. 
"[A] [...] A un enfant de maison qui recherche les lettres, non pour le gaing (car une fin si abjecte est indigne de la grace et faveur des Muses, et puis elle regarde et depend d'autruy), ny tant pour les commoditez externes que pour les siennes propres, et pour s'en enrichir et parer au dedans, ayant plustost envie d'en tirer un habil'homme qu'un sçavant, je voudrais ..."

[Para uma criança de família nobre, que procura as letras não para o ganho (pois uma finalidade tão abjeta é indigna da graça e do favor das musas, e além disso se volta para outros e deles depende), nem tanto pelos benefícios externos como pelos seus próprios, e para com elas se enriquecer e adornar-se interiormente, pretendendo obter delas antes um homem inteligente do que um homem sábio, eu gostaria...] (I, 26, 150)

Desnecessário dizer que esse enfant de maison é o filho de família nobre que se educa, não para servir, mas para ser livre, não de uma liberdade, evidentemente, incondicional, mas sujeita a obediências várias: às leis, à lealdade ao rei, aos decoros sociais em diversas circunstâncias. Há todo um conjunto de "deveres" que emolduram esse centro de liberdade que se circunscreve n'Os Ensaios para o indivíduo, e que aparece discretamente aqui tanto no aviltamento do fim enquanto ganho, aos olhos das divindades que presidem as artes, como na dependência de outrem em que incorre o mesmo ganho, em se tratando das relações entre os homens. O que se enfatiza aqui, no entanto, é o que propriamente se busca na lide com as "letras". Claro está que por "letras" se entende na pena do humanista Montaigne, também, a mesma "ciência" de que se falava há pouco, pois pelas letras, ou melhor, pelos livros, 
esta se veicula e se aprende. Excluem-se, em suma, como objetivo da relação com elas, o "ganho" e as "comodidades externas" (riqueza, fama, glória), para que ao procurar as "letras" se busquem as "comodidades próprias", a riqueza e o adorno internos, já que se tem em vista formar (instituir) um habil'homme e não um sçavant. Esse par, não excludente, aliás, é, com leves variações, outra constante d'Os Ensaios. Mais um traço inserido do mesmo éthos lembrado acima, e que compõe com outros um conjunto de opiniões antigas e reputadas sobre como convém a um nobre dedicar-se ao estudo. O contraste é nítido entre aquele que busca e adquire ciência para professá-la e ganhar por isso, ou seja, o uso servil das letras que as transforma em meio de vida, e o que a busca e adquire para empregá-la oportunamente na condução da própria vida. Além disso, a oposição, que já desponta aqui, entre, de um lado, o próprio e interno que se enriquece e paramenta no estudo, constituindo um recurso sólido de que se dispõe para o conselho e a ação; e, de outro, o externo e alheio (mero meio para servir, relacionado ao ganho), será fundamental para a ordenação do argumento que apresenta a nouvelle manière, na sequência do passo que ora analisamos. Retomemo-lo no ponto em que o deixamos suspenso e complementemos com a característica que se exige do preceptor:

“... je voudrais aussi qu'on fut soigneux de luy choisir un conducteur qui eust plutost la teste bien faicte que bien pleine, et qu'on y requit tous les deux, mais plus les meurs et l'entendement que la science; et qu'il se conduisist en sa charge d'une nouvelle maniere."

[...eu gostaria que se tivesse o cuidado de escolher-Ihe um preceptor que antes tivesse a cabeça bem feita do que bem cheia, e que se lhe exigissem ambas as 
coisas, porém mais os costumes e o entendimento do que a ciência; e que em seu encargo ele se conduzisse de uma forma nova.] (id. ibid.)

O primeiríssimo ato que condiciona a educação e sua qualidade é o da escolha do preceptor e do procedimento básico na condução de sua "tarefa" (charge). Mais uma vez a "ciência" não está excluída, mas não detém a primazia dada ao par "costumes e entendimento". Em princípio, portanto, não se deve pensar que essa teste bien faicte não guarda relações com a ciência; ela é própria do habil'homme e de sua lide, liberal, com as letras, lide através da qual, pelo menos em parte, forma e exerce seus costumes e seu entendimento. Já a teste bien pleine parece ser exatamente aquela que confere primado ao saber e à ciência, e se identifica aqui com o sçavant de há pouco. Isso já nos dá uma primeira pista, a ser corroborada e confirmada, do que Montaigne entende por uma teste bien faicte, porque precisamente com ela contrasta uma "cabeça bem cheia": esta é uma cabeça plena de conhecimentos vários, de ciências mais ou menos úteis dependendo da pessoa que faz uso delas e do serviço que são chamadas a prestar; aquela, uma cabeça formada para o mundo das ações, da prática, pois conjuga capacidade de compreender situações com regulação de comportamentos, excelência intelectual com virtude moral. Resta saber que espécie de relações são estabelecidas entre esse conducteur e seu discípulo e como ele deve conduzir a criança no seu desenvolvimento. Mas, vejamos como se entende essa nouvelle maniere até aqui apenas enunciada, e se ela confirma essa primeira suspeita colhida nesse traço do "caráter" do preceptor. 
O primeiro ponto atacado quando ao modo de proceder, ou seja, sobre a manière nova que se propõe, surge em contraste com um método em que apenas o preceptor fala e os alunos escutam. ${ }^{13}$ Montaigne pede que se corrija "esta parte" e, exigindo que o processo assuma a forma de um diálogo conduzido pelo mestre, diz que

“[...] de belle arrivé, selon la portée de l'ame qu'il a en main, il commençast à la mettre sur la montre, luy faisant gouster les choses, les choisir et discerner d'elle mesme: quelquefois luy ouvrant chemin, quelquefois le luy laissant ouvrir. Je ne veux pas qu'il invente et parle seul, je veux qu'il escoute son disciple parler à son tour."

[...já desde o início, dependendo do alcance da alma que tiver nas mãos, começasse a colocá-la na parada, fazendo-a experimentar as coisas, escolhêlas e discernir por si mesma; às vezes abrindo-Ihe caminho, às vezes deixando-a abri-lo. Não quero que ele invente e fale sozinho, quero que escute o discípulo falar por sua vez.] (ibid.)

\footnotetext{
${ }^{13}$ Nosso propósito não será, aqui, o de identificar o alvo histórico dessa crítica, que o texto montaigniano não se preocupa em tornar preciso, pois, ao que parece, invectiva tanto os procedimentos das escolas ainda sob o controle dos escolásticos, o que se tornou comum entre humanistas, como os próprios colégios humanistas, a julgar pelo modo como Montaigne avaliou o da Guyenne, onde em parte foi educado. Importa-nos mais observar os traços da educação que se propõem nesse contraste. Portanto, não se fará aqui uma reconstituição dos currículos e dos modos de proceder do tempo, nem se procurará identificar esse alvo. Isso porque não nos interessa a reflexão de Montaigne sobre a educação enquanto tal e o debate no qual, certamente, deve estar interferindo em seu meio, mas somente o que nesses textos pode nos esclarecer sobre o desenvolvimento da vis pretendida para o ensaísta.
} 
Note-se 0 acento na experiência, na escolha e no discernimento das coisas. $O$ aluno é convidado desde logo ao exercício proporcionado à capacidade de sua alma. Mas não basta que o professor escute e coloque o aluno à prova e em experiência efetiva das coisas, obrigando-o a escolher por si e discernir. É necessário que também saiba se ajustar às forças do aluno que tem em mãos, tarefa condescendente e difícil de que Montaigne se julga incapaz:

"A faute de cette proportion nous gastons tout: et de la sçavoir choisir, et s'y conduire bien mesureement, c'est l'une des plus ardues besongnes que je sçache: et est effaict d'une haute ame et bien forte, sçavoir condescendre à ses allures pueriles et les guider. Je marche plus seur et plus ferme à mont qu'à val." [Por falta dessa proporção estragamos tudo; e saber escolhê-la e conduzir-se compassadamente é uma das tarefas mais árduas que conheço; e é ação de uma alma elevada e muito forte saber condescender com seus passos infantis e guiá-los. Ando com mais segurança e mais firmeza ao subir do que ao descer.] (ibid.)

Ora, dado esse ajuste e adequação do mestre ao discípulo, essa "proporção", e colocado este último em posição ativa, é natural que se espere dele mais do que a memória das lições. É o que se considera dever exigir o preceptor de seu discípulo, na sequência imediata, fundamental para a compreensão do núcleo do problema que examinamos sobre a formação de uma teste bien faicte: 
"Qu'il ne luy demande pas seulement compte des mots de sa leçon, mais du sens et de la substance, et qu'il juge du profit qu'il aura fait, non par le tesmoignage de sa memoire, mais de sa vie. Que ce qu'il viendra d'apprendre, il le lui face mettre en cent visages et accommoder à autant de divers subjets, pour voir s'il l'a encore bien pris et bien faict sien [...]."

[Que ele Ihe peça contas não apenas das palavras de sua lição mas sim do sentido e da substância, e que julgue sobre o benefício que tiver feito não pelo testemunho de sua memória e sim pelo de sua vida. Aquilo que tiver acabado de ensinar, faça a criança colocá-lo em cem facetas e adaptar a tantos outros diversos assuntos, para ver se ela realmente o captou e incorporou...] (id., p. 151)

O cerne da crítica que se move aqui contra um tipo de educação, segundo Montaigne, muito em voga em seu tempo, é o de que ela não pede mais do que as "palavras da lição", a "memória" do que o professor, falando e inventando sozinho, apresenta ao aluno. A educação que se propõe e seus efeitos, ao contrário, serão medidos pela "vida" do aluno, ou seja, pelas ações e pelos juízos de que o aluno, a partir da instrução recebida, se torna passo a passo capaz. Daí o imperativo de modificar a lição recebida ou "acomodar" a instrução a outros "assuntos", como prova de "assimilação", traduzida aqui em termos de apreensão e apropriação - os termos são mesmo esses: prendre e faire sien por parte do aluno. E, daí, também, o juízo, concretizado pela metáfora da digestão, que se segue: 
"[A] C'est tesmoignage de crudité et indigestion que de regorger la viande comme on l'a avallé. L'estomac n'a pas faict son operation, s'il n'a faict changer la façon et la forme à ce qu'on luy avait donné à cuire."

$[[A]$ É prova de crueza e de indigestão regurgitar o alimento como foi engolido. $O$ estômago não realizou sua operação, se não fez mudar a característica e a forma do que Ihe deram para digerir.] (ibid.)

A necessidade de apropriação posta leva Montaigne imediatamente a considerar, em um acréscimo em camada $[B]$, a relação de crédito e confiança diante das várias autoridades e o modo de sujeição em que a alma se encontra em relação aos saberes e lições alheios:

"Nostre ame ne branle qu'à credit, liée et contrainte à l'appetit des fantasies d'autruy, serve et captivée soubs l'authorité de leur leçon. On nous a tant assubjectis aux cordes que nous n'avons plus de franches allures. Nostre vigueur et liberté est esteinte."

[Nossa alma só se move por crédito, ligada e constrangida ao apetite das fantasias de outros, serva e cativa sob a autoridade do ensinamento destes. Tanto nos submeteram às cordas que já não temos livres os passos. Nosso vigor e nossa liberdade estão extintos.] (ibid.)

Bem ao contrário, a institution, nos termos montaignianos, parece se definir como uma disciplina em que o aluno, movido pelo mestre, deve antes passar por crivo tudo aquilo que vier a acatar, e mesmo restar em dúvida, 
quando não houver condições de assentir a uma ou outra doutrina ou princípio examinados:

“[A] Qu'il luy face tout passer par l'estamine et ne loge rien en sa teste par simple authorité et à credit; les principes d'Aristote ne luy soyent principes, non plus que ceux des Stoiciens ou Epicuriens. Qu'on luy propose cette diversité de jugemens: il choisira s'il peut, sinon il en demeurera en doubte. [C] II n'y a que les fols certains et resolus."

[[A] Que ele o faça passar tudo pelo crivo e nada aloje em sua cabeça por simples autoridade e confiança; que os princípios de Aristóteles não Ihe sejam princípios, não mais que os dos estóicos e epicuristas. Que Ihe proponham essa diversidade de opiniões; ele escolherá se puder; se não, permanecerá em dúvida. [C] Seguros e convictos há apenas os loucos.] (ibid.)

À parte a nota cética desse preceito, que convida tranquilamente a permanecer em dúvida tendo examinado uma diversidade de juízos das várias doutrinas, é de reparar com que desembaraço Montaigne trata as autoridades, Aristóteles à frente. Nenhuma proposição, nenhum princípio, nenhuma verdade vale simplesmente pelo peso do nome que a sustentou no passado, é o que se afirma aqui. Tudo se deve passar por um "filtro" (estamine) antes de se assentir a alguma asserção e tê-la por verdade, ou seja, antes de "alojá-la na cabeça". No entanto, é de reparar também que a instrução passa pelo exame das doutrinas, múltiplas, e se alimenta delas. Não há um desprezo pelas doutrinas do passado, ainda que se exija exame crítico e que não se confira de antemão 
prerrogativa a nenhuma delas e se dê amplo espaço para a dúvida. Aqui não se faz tabula rasa do saber e se instaura um novo saber. Aqui se propõe e se examina uma "diversidade de julgamentos". Embora a "certeza" e a "resolução" sejam próprias dos "loucos", a capacidade de julgamento de uma teste bien faicte se forma no corpo a corpo com os saberes reputados de uma tradição, que se deve examinar e criticar, que se pode aceitar ou descartar, mas que não são recusados em bloco e de uma vez por todas. A frágil possibilidade de escolha permanece aberta, ainda que não se possa deixar de reconhecer que a simpatia do Ensaísta pareça recair sobre a permanência em dúvida e a constante busca, conforme ao Ceticismo de que se impregnam as páginas dos Ensaios. No entanto, mais do que insistir no traço crítico e suspensivo do pensamento montaigniano, cumpre destacar, e isso nos interessa mais no momento, o papel fundamental exercido pela assimilação inteligente das opiniões reputadas das autoridades na formação do entendimento e do juízo que está em questão. A sequência do texto deixa isso ainda mais claro. Leiamos:

"Car s'il embrasse les opinions de Xenophon et de Platon par son propre discours [=raison], ce ne seront plus les leurs, ce seront les siennes. [C] Qui suit un autre, il ne suit rien. II ne trouve rien, voire il ne cerche rien. «Non sumus sub rege; sibi quisque se vindicet.») Qu'il sache qu'il sçait, au moins."

[Pois se ele abraçar as opiniões de Xenofonte e de Platão por seu próprio julgamento, não serão mais as opiniões deles, serão as suas. [C] Quem segue um outro nada segue. Nada encontra, e até mesmo nada procura. Não vivemos sob o domínio de um rei; que cada qual disponha de si mesmo. Que ele saiba que sabe, pelo menos.] (ibid.) 
Como se vê, as opiniões de autoridade, logo, alheias, devem ser abraçadas pelo "discurso próprio", isto é, não se pede mais nem menos do que o entendimento delas. Assim, tendo passado pelo crivo da própria razão, talvez fosse melhor dizer do exame racional e discursivo (discours), as opiniões abraçadas deixam de pertencer às autoridades que primeiro as sustentaram e de alheias se transmudam em próprias. Indiscutível que Montaigne reivindica a possibilidade de instruir o discípulo dentro de uma disciplina que o forme, não certamente para a plena autonomia, mas para a autarcia que se constrói no diálogo cerrado e crítico com as autoridades. Essa autarcia, como teremos oportunidade de discutir, tem nome próprio em Montaigne: suffisance. Tal "suficiência", que não está sob domínio de ninguém, mas que se reivindica a si mesma para si, como deixa clara a citação de Sêneca ${ }^{14}$, é em tudo contrária a atitude "daquele que segue a outrem" e, diga-se, acata sem verdadeiro exame e acolhimento as opiniões alheias, ainda que autorizadas, e verbalmente apenas as repete. Sua sujeição não é nem mesmo a de um dogmático consequente, pois este sabe ao menos que sabe. E testemunha até mesmo de uma ignorância que não atenta nem mesmo para o que sabe, já que o que sabe é apenas memória dos discursos e razões de um outro, reproduzidas, mas não entendidas e assimiladas, como o conjunto do passo que estamos lendo permite afirmar. Este que não segue nada, não encontra nada, e mesmo nem busca nada, também tem nome próprio em Montaigne: "tolo" (sot). E difere tanto deste anti-Sócrates,

${ }^{14}$ Epístolas a Lucílio, XXXIII. 
que sabe que sabe, como daquele, mais afim às preferências do nosso autor, que se instala na busca, consciente de que não sabe. Não obstante isso, não há como negar que as opiniões de Xenofonte e Platão permanecem aqui investidas de legitimidade, ao lado de tantas outras, e dão matéria para o exercício e exame do discípulo que se instrui.

Não basta, porém, que se abracem opiniões no próprio discurso, tendo-as filtrado pelo crivo do exame racional e discursivo, assimilado e entendido. A instrução proposta visa ainda efeitos mais profundos do que 0 conhecimento de certas lições:

“[A] II faut qu'il emboive leurs humeurs, non qu'il aprenne leurs preceptes. Et qu'il oublie hardiment, s'il veut, d'où il les tient, mais qu'il se les sçache approprier. La vérité et la raison sont communes à un chacun, et ne sont non plus à qui les a dites premierement, qu'à qui les dict apres. [C] Ce n'est non plus selon Platon que selon moy, puis que luy et moi l'entendons et voyons de mesme."

[[A] É preciso que se impregne dos humores deles, não que aprenda seus preceitos. E que, se quiser, esqueça imediatamente de onde os obtém, mas que saiba assimilá-los. A verdade e a razão são comuns a todos, e não pertencem a quem as disse primeiramente mais do que a quem as diz depois. [C] Não é segundo Platão mais do que segundo eu mesmo, já que ele e eu o entendemos e vemos da mesma forma.] (ibid., 150-51)

O que se lê, em primeiro lugar aqui, é que a instrução não pára no nível dos preceitos que se podem muito bem assimilar e saber mais do que de 
cór. Tais preceitos têm efeitos sobre os humores, e, daí, certamente sobre as ações. Por isso o que se apregoa é que o discípulo se impregne ou "embeba" (emboive) com os mesmos humores desses mestres, não simplesmente conhecendo e repetindo seus "preceitos" - o que seria ainda, mesmo havendo entendimento, permanecer apenas no nível verbal e discursivo da instrução -, mas obedecendo-os e levando-os a efeito: quer dizer, traduzindo-os em ação, que, repetida, forja uma disposição estável. O que se aprende não permanece simplesmente como um saber sobre as coisas, um saber que se poderia muito bem professar, e não praticar. Mas dele se deriva a orientação para as ações e a vida. Essa "impregnação" de modelos, essa apropriação de opiniões alheias, se projeta e interfere tanto na capacidade discursiva e intelectiva, como na ação mesma daquele que se instrui conforme essa disciplina. Reencontraremos esse aspecto prático do pensamento montaigniano várias vezes pelo caminho. Vale ainda observar que tal "impregnação" chega até a ousadia de esquecer a fonte de que se tomou um preceito, visto que, devidamente assimilado e apropriado, a "verdade e razão" dele é comum e não pertence mais àquele que o encontrou do que àquele que dele se apropriou. O descobridor de uma "verdade", não tem mais direitos sobre ela do que aquele que dela soube se apropriar, que a soube entender e empregar em diversa circunstância. Isso nos dá bem a medida de como o horizonte da originalidade está distante ainda da "criação", ou será melhor dizer "invenção", como ela vai sendo pensada e concebida nessas páginas do De l'institution. Mas outra coisa ainda espanta nesse passo: ouvir da boca de um autor que confessa tanta afinidade com o Ceticismo que a "razão e 
a verdade são comuns" aos que as descobriram e aos que as aprenderam daqueles que as descobriram. Não é momento de avaliar a adoção ou o pertencimento de Montaigne ao Pirronismo. É preciso, contudo, observar que não é tão simples alegar que esse texto pertence a um período anterior ao contato mais estreito travado com os textos de Sexto Empírico na tradução de Henri Estienne. Não basta dizer que se trata de uma alegação em camada [A] do primeiro livro. No meu entender, por duas razões: 1) em matéria moral e no que tange à excelência no discorrer, um certo vocabulário da verdade e da razão permanecerá constante, até mesmo em texto de acréscimos da camada [C]; 2) essa disciplina que vimos descrevendo e que visa formar o juízo, não passa sem o emprego efetivo da razão discursiva, razão essa que se move sondando e examinando e buscando, em suma, orientação para o governo de si mesmo, mas que o faz sempre, confrontando a própria experiência com os discursos autorizados do passado, ou os discursos entre si. E, o que é mais importante, ajuizando em matéria moral e discursiva com uma segurança que admira o leitor. Não se poderia tratar Platão como um dogmático entre outros diante do acréscimo em camada [C] que lemos no passo citado acima.

Que se tratava de definir a "imitação", nos termos como a concebe propriamente Montaigne, já era de desconfiar, quando não pela sequência que nos brinda com a famosa metáfora das abelhas, tomada certa e oportunamente a Sêneca, e articulada aqui ao propósito primeiro da institution:

"[A] Les abeilles pillotent deçà delà les fleurs, mais elles en font apres le miel, qui est tout leur; ce n'est plus thin ny marjolaine: ainsi les pieces empruntées 
d'autruy, il les transformera et confondera, pour en faire un ouvrage tout sien: à sçavoir son jugement. Son institution, son travail et estude ne vise qu'à le former."

[[A] As abelhas sugam das flores aqui e ali, mas depois fazem o mel, que é todo delas: já não é tomilho nem manjerona. Assim também as peças emprestadas de outrem ele irá transformar e misturar, para construir uma obra toda sua: ou seja, seu julgamento. Sua educação, seu trabalho e estudo visam tão somente a formá-lo.] (ibid., 152)

Aqui não cabe mais dúvida, a formação do julgamento é a visada desse "trabalho e estudo", é o télos dessa institution. E o julgamento se forma a partir da assimilação e posterior transformação de toda matéria que lhe é dada como instrução. As "peças" que toma de empréstimo, o trabalho do entendimento as transformará e confundirá (não só no sentido de misturá-las, mas de fundi-las umas às outras) fazendo disso uma obra inteiramente própria. O aluno, aqui, é convidado a esquecer das fontes e calá-las quando as emprega, seja discorrendo, seja agindo, desde que tenha sabido apropriar-se delas, e construir a partir delas sua própria obra:

“[C] Qu'il cele tout ce dequoy il a esté secouru, et ne produise que ce qu'il en a faict. Les pilleurs, les enprunteurs mettent en parade leurs batisments, leurs achapts, non pas ce qu'ils tirent d'autruy. Vous ne voyez pas les espices d'un homme de parlement, vous voyez les alliances qu'il a gaignées et honneurs à ses enfans. Nul ne met en compte publique sa recette: chacun y met son acquest." 
[[C] Que ele cale sobre tudo de que se valeu e mostre apenas o que fez disso. Os que pilham, os que tomam emprestado fazem exibição de suas construções, de suas compras, não do que tiram dos outros. Não vedes os ganhos de um homem do parlamento: vedes as alianças que ele obteve e as honrarias para seus filhos. Ninguém faz contas públicas da própria receita; todos fazem do que adquiriram.] (ibid.)

O que não se fala aqui tão explicitamente é que se trata também de um cultivo do empréstimo na confecção das obras escritas, e mais do que isso, de um uso do furto, mas de um furto velado pela capacidade do entendimento que o transformou e rearticulou em uma obra própria, ainda que construída às expensas do alheio. Esse imbricamento entre o saber alheio herdado e o trabalho do entendimento que não se presta ao simples endosso de um saber dogmático definitivo, nem a uma ruptura radical com as opiniões reputadas do passado, e sim a forjar uma capacidade de julgamento e ação, não poderia ficar mais claro do que como é expresso no auge desse movimento sobre a nouvelle maniere: "le guain de nostre estude, c'est en estre devenu meilleur et plus sage" [O proveito de nosso estudo está em com ele nos termos tornado melhores e mais sensatos.] (ibid.). Os dois últimos termos confirmam a impressão inicial de que o conselho dado sobre a institution visava formar um homem capaz de ação e ao mesmo tempo sábio. Todo o sentido dessa capacidade prática, dessa sagesse, só ficará inteiramente claro depois. Por ora, basta reforçarmos a ideia de que a práxis humana ganha terreno aqui sobre uma atitude de conhecimento teorético e sobre a aquisição das ciências dogmáticas. 
Coroando toda essa discussão, a asseveração forte de um primado do entendimento sobre a cultura da memória. Embora longa, a citação vale como um apanhado de várias observações que ficaram nesse percurso:

"[A] C'est, disoit Epicharmus, l'entendement qui voyt et qui oyt, c'est l'entendement qui approfite tout, qui dispose tout, qui agit, qui domine et qui regne: toutes autres choses sont aveugles, sourdes et sans ame. Certes nous le rendons servile et coüarde, pour ne luy laisser la liberté de rien faire de soy. Qui demanda jamais à son disciple ce qu'il luy semble [B] de la Rethorique et de la Grammaire $[A]$, de telle ou telle sentence de Ciceron? On nous les placque en la memoire toutes empennées, comme des oracles où les lettres et les syllabes sont de la substance de la chose. [C] Sçavoir par coeur n'est pas sçavoir: c'est tenir ce qu'on a donné en garde à sa memoire. Ce qu'on sçait droittement, on en dispose, sans regarder au patron, sans tourner les yeux vers son livre. Facheuse suffisance, qu'une suffisance purement livresque! Je m'attens qu'elle serve d'ornement, non de fondement, suivant l'advis de Platon, qui dict la fermeté, la foy, la sincerité estre la vraye philosophie, les autres sciences et qui visent ailleurs, n'estre que fard.

[A] Je voudrais que le Paluel ou Pompée, ces beaux danseurs de mon temps, apprinsent des caprioles à les voir seulement faire, sans nous bouger de nos places, comme ceux-cy veulent instruire nostre entendement, sans l'esbranler: [C] ou qu'on nous apprinst à manier un cheval, ou une pique, ou un luth, ou la voix, sans nous y exercer, comme ceux icy nous veulent apprendre à bien juger et à bien parler, sans nous exercer ny à parler ny à juger."

[[A] A inteligência, dizia Epicarmo, é que vê e que ouve, a inteligência é que tudo aproveita, que tudo dispõe, que age, que domina e que reina; todas as outras 
coisas são cegas, surdas e sem alma. É bem verdade que a tornamos servil e covarde, por nunca Ihe darmos a liberdade de fazer coisa alguma por si mesma. Quem algum dia perguntou a seu discípulo o que Ihe parece [B] da retórica e da gramática $[A]$, desta ou daquela frase de Cícero? Pespegam-nas em nossa memória todas emplumadas, como oráculos em que as letras e as sílabas participam da substância da coisa. [C] Saber de cor não é saber: é conservar o que foi entregue à guarda da memória. Do que sabemos efetivamente, dispomos sem olhar para o modelo, sem voltar os olhos para o livro. Desagradável competência, a competência puramente livresca! Espero que ela sirva de ornamento, não de fundamento, segundo o parecer de Platão, que afirma que a firmeza, a honradez, a sinceridade são a verdadeira filosofia, enquanto as outras ciências e que visam alhures são apenas ouropéis.

[A] Eu gostaria que Paluel e Pompeu, belos dançarinos de meu tempo, ensinassem cabriolas simplesmente vendo-as ser feitas, sem nos movermos de nossos lugares, como estes querem instruir nossa inteligência sem a colocar em movimento; $[C]$ ou que nos ensinassem a lidar com um cavalo, ou com um pique, ou com um alaúde, ou com a voz, sem nos treinar nisso, como estes querem ensinar-nos a bem julgar e a bem falar sem nos treinar nem em falar nem em julgar.] (Ibid.)

Certamente, a "liberdade" reclama aqui seus direitos, contra a servilidade e covardia dos que se sujeitam à autoridade do texto "oracular" de Cícero, ou de um Cícero, cujo texto "sagrado" é tomado por muitos como oráculo e repetido sílaba a sílaba, palavra a palavra. Certamente, se afirma também a 
necessidade de instruir o discípulo exercitando-o. Mas que não se deixe de prestar atenção que é ainda na autoridade de uma "advertência" (advis) de Platão que Montaigne apoia sua indisposição quanto a uma suffisance purement livresque, contrária àquela que se mencionou um pouco acima. Se o "fundamento" não está puramente nos livros, ele se constrói a partir também do convívio e comércio com os livros que guardam a memória das grandes almas do passado e seus pensamentos. Este mesmo texto de Montaigne que vimos comentando testemunha, com suas várias citações, a importância que assume ainda a palavra autorizada no seio dessa cultura da alma que se tenta erigir. Exigir que o entendimento se aproprie e se liberte do jugo da autoridade é mesmo o sentido mais preciso das lições que Montaigne colhe nos autores que lê. Portanto, não é de uma simples ruptura com suas lições que podemos falar aqui.

Segue a essas disposições gerais sobre a educação, propriamente um "programa ou currículo" que se divide claramente em duas frequentações necessárias à aprendizagem desse menino fidalgo: 1) a frequentação do mundo e o "comércio" com os homens vivos, de casa e de alhures, ou seja, o domínio das relações e das experiências morais efetivas; 2) a dos livros, que se configuram em uma outra espécie de frequentação e diálogo, porém, nesse caso, com os homens mortos, mas em cujos escritos se encontra matéria preciosa para o exercício do julgamento. Não nos interessará agora entrar em detalhes desse programa de estudos traçado no capítulo sobre a educação. Importa mais percorrer outros domínios que nos permitam, mais claramente, 
discernir melhor o modo de desempenho dessa cabeça formada pela institution montaigniana. Que nos sirva de guia, no entanto, esses dois ramos do programa traçado: a frequentação mundana e os livros, dois objetos de predileção nas considerações do Ensaísta.

\section{b. A suffisance em exercício}

\section{i. O comércio com os livros}

Comecemos pelos livros. Montaigne, além de muita observação esparsa n'Os Ensaios, dedica ao tema de como se "liga aos livros" todo um capítulo: o ensaio II, X, "Des livres". Antes de entrar propriamente no rol das leituras e autores que prefere, em poesia, filosofia moral e história, todo o início do capítulo é dedicado ao esclarecimento do que se pode esperar da leitura dos Ensaios. É admirável a nonchalance com que abre suas considerações sobre o estatuto de sua própria obra, e mesmo a audácia. Vale a pena reler:

“[A] Je ne fay point de doute qu'il ne m'advienne souvent de parler de choses qui sont mieus traictées chez les maistres du mestier, et plus veritablement. C'est icy purement l'essay de mes facultez naturelles, et nullement des acquises; e qui me surprendra d'ignorance, il ne fera rien contre moy, car à peine respondroy-je à autruy de mes discours, qui ne m'en responds point à moy; ny n'en suis satisfaict. Qui sera en cherche de science, si la pesche où elle se loge: il n'est rien dequoy je face moins de profession. Ce sont icy mes fantasies, par lesquelles je ne tasche point à donner à connoistre les choses, mais moy: elles me seront à l'adventure connuez un jour, ou l'ont autresfois esté, 
selon que la fortune m'a peu porter sur les lieux où elles estoient esclaircies. Mais [C] il ne m'en souvient plus."

[Não tenho dúvida de que amiúde me advém falar de coisas que são mais bem tratadas nos mestres do ofício, e mais verdadeiramente. Está aqui puramente o ensaio de minhas faculdades naturais, e não das adquiridas; e quem me surpreender em delito de ignorância nada fará contra mim, pois dificilmente responderei a outrem por minhas opiniões - eu que não respondo por elas a mim mesmo nem estou satisfeito com elas. Quem estiver em busca de conhecimento que o pesque onde ele se aloja: não há nada que eu professe menos. Estão aqui minhas fantasias, com as quais não procuro dar a conhecer as coisas e sim a mim mesmo: talvez um dia elas venham a ser conhecidas por mim, ou o tenham sido outrora, conforme o acaso me possa ter levado aos locais onde eram esclarecidas. Porém [C] não me lembro mais.] (II, 10, 407-8)

A desenvoltura com que Montaigne afirma aqui não ter nenhuma dúvida de que fala das coisas que os "mestres do ofício" tratam "melhor e mais verdadeiramente" nos desperta quanto ao verdadeiro propósito do livro, pois a intenção aqui não é demonstrar que é sabedor e conhecedor dessas coisas. Mas, sim, "ensaiar" as "faculdades naturais" que possui. Não quer mostrar como é instruído nas matérias que trata, mas apenas como se sai, com recursos exclusivamente seus, diante dessas coisas, pensando-as. Quem o surpreender em ignorância não fará nada contra ele, já que, desarma um possível crítico ou detrator, adiantando que "dificilmente respond[e] a outrem por [seus] discursos, [ele] que não responde por eles a [si] mesmo, nem [se] satisfa[z] com eles" (ou 
seja, o que diz sobre as coisas, as diz como leigo e admite estar sujeito a erro). Pouco importa para aquele que assume de antemão que pode estar em ignorância diante das matérias, uma vez que não professa nenhuma delas. E despacha, com tranquilidade, aquele leitor que viesse ao livro em busca de uma "ciência". No livro em geral e, em especial, no capítulo em que fala de seus livros preferidos, coloca apenas suas "fantasias", sem que as encarregue de dar a conhecer as coisas; bem ao contrário, encarrega-as de dar a conhecer a si mesmo. As coisas serão um dia conhecidas por ele, ou foram conhecidas outrora, conforme a fortuna o tenha levado aos lugares em que elas sejam esclarecidas, mas ele esqueceu-se disso.

Tranquila e ousadamente se marcam aqui os limites da empresa de conhecimento assinalados ao livro. Não se pode, aceitando-se literalmente o aviso dado, buscar nele conhecimento nenhum das coisas tratadas. $O$ único conhecimento que se obterá, através desse registro das "fantasias" que o livro veicula, é relativo ao próprio Montaigne. Ele poderia dizer qualquer bobagem - e não faltam observações em toda obra que rebaixam o caráter das considerações que arrola -, fazer observações impertinentes sobre as coisas; porém, nenhum leitor se convence facilmente de que seus juízos não são pertinentes, embora ousados e plenos de licença em alguns casos. Além disso, essa intenção explicitada aqui, muito próxima ao que diz a nota $A u$ lecteur aposta ao conjunto dos três livros, parece apontar para uma quebra de expectativa dos leitores, se esperassem ali se instruir sobre os assuntos tratados. O serviço mais óbvio que se espera dos livros, Montaigne não o presta aos seus leitores. Instrui-os 
abertamente, contudo, acerca dessa posição tomada no que diz respeito ao tratamento erudito e especializado do que explana. E ele o diz justamente em um capítulo dedicado aos livros, onde deixa igualmente claro o gosto que tem em buscar, ao ler, mais o conhecimento dos autores que lê que dos assuntos dos quais tratam esses autores. Seu livro não expõe ciência, mas emprega a ciência que seu autor tem das coisas que aborda apenas com seus recursos naturais. Montaigne regra e ordena a própria recepção que espera de seu livro em conformidade com a que observa como leitor.

Ora, com isso, fica claro que as matérias foram rebaixadas a condição de mera ocasião para o exercício do juízo. O que não significa que, desvinculando suas "fantasias" de um comprometimento com a ciência das matérias, ele assuma uma ignorância primária em relação a elas: "Et si je suis homme de quelque leçon, je suis homme de nulle retention" [ $E$ se sou homem de alguma leitura, sou homem de nenhuma memória.] (II, x, p. 408). Do mesmo modo que não limitava a instrução da criança, como vimos, à memória e repetição do saber alheio, o Montaigne escritor não quer explicitamente que tomem sua obra como simples obra da memória e endosso de lições alheias. Isso, porém, não significa que ele faça abstração de toda instrução recebida e assimilada. É no rastro de pegadas alheias que se move em boa parte do tempo, repisando temas e problemas. Ele é um "homme de leçon", isto é, muito do que escreve é fruto da assimilação ativa do saber alheio. Resta, contudo, que a "certeza" em relação à verdade do que diz não está mais em questão, e sim a maneira ("façon") como vai alinhavando as matérias de modo oportuno: 
"[A] Ainsi je ne pleuvy aucune certitude, si ce n'est de faire connoistre jusques à quel poinct monte, pour cette heure, la connoissance que j'en ay. Qu'on ne s'attende pas aux matieres, mais à la façon que j'y donne." [Assim, não dou garantia de certeza alguma, a não ser de revelar até que ponto chega, neste momento, o conhecimento que tenho delas. Não se dê atenção às matérias e sim à maneira como as apresento.] (ibid.)

Esse primado da maneira sobre as matérias pode ser avaliado mais profundamente pela forma como Montaigne discute uma outra conversa, essa em presença, o que veremos com a análise de sua "arte da conversação".

\section{ii. O comércio com os homens}

Na nota que apõe ao "De l'art de conferer" (III, VIII), Pierre Villey já nos fazia notar que, neste capítulo, Montaigne quisera "juntar o exemplo ao preceito", e por isso, "nunca talvez o seu estilo tenha tido a cor e o movimento do estilo da conversação familiar" quanto tem aí. De fato, a intenção do ensaísta de produzir um efeito de causerie familière, no capítulo que trata expressamente da conversação, afeta - esta a impressão no leitor - tanto o estilo propriamente dito, a léxis montaigniana, quanto o andamento e o desenvolvimento do 
arrazoado, a "disposição" de suas partes, ou sua táxis. ${ }^{15} \mathrm{~A}$ impressão é de uma grande liberdade com o desenvolvimento da "matéria", o que, aliás, é próprio da experiência de leitura de qualquer ensaio montaigniano, mormente os mais desenvoltos do terceiro livro. Temas subsidiários emergem, depois somem, e mais adiante ressurgem. $O$ texto frequentemente escapa para longas digressões. E só com algumas boas leituras, "diligentíssimas", o conjunto dos elementos que estão dispersos e aparentemente deslocados ganham coesão e começam a revelar para o leitor sua "unidade". Como neste texto, em grande parte, trata-se explicitamente do problema da "forma", embora pelo viés das trocas verbais entre os interlocutores de uma conversa, suas questões, de algum modo, se projetam na prática do escritor, e o esclarecimento da manière que aí se propõe ajuda a lançar alguma luz sobre a significação do ensaio como forma a um só tempo de pensamento e de escrita. Gostaria, assim, de retomar brevemente aqui dois pontos de um estudo anterior ${ }^{16}$ sobre a estruturação interna deste capítulo: o primeiro deles é o que chamei de uma "conversão para a maneira"; o outro, tributário daquele, é uma discussão sobre a noção de

\footnotetext{
${ }^{15}$ Tomo os termos tais como eles são definidos dentro da tradição dos tratados retóricos desde os antigos. Para uma definição das partes da arte ou das tarefas que deve cumprir o orador para produzir seu discurso, veja-se, por exemplo, Cícero, De inventione I, 9. (Cf. também Rhet. ad Herennium I II, 2.)

${ }^{16}$ Cf. QUERUBINI, Edson. Montaigne e a Arte da Conversação: a conversão para a "maneira". Dissertação (Mestrado). Faculdade de Filosofia, Letras e Ciências Humanas, Departamento de Filosofia, Universidade de São Paulo, São Paulo: 2009.
} 
"ordem" que ali se expõe. Para tanto, comecemos por retomar o fio argumentativo do ensaio em sua primeira parte.

Podemos seguramente apontar a manière como o tema mais fundamental a que se consagra a totalidade do "De l'art de conferer". Que seja assim, o próprio ensaísta nos avisa expressamente a certa altura do arrazoado: "car nous sommes sur la manière, non sur la matière du dire" [Pois estamos na maneira, não na matéria do dizer] (III, 8, p.928). A operação que está, efetivamente, em questão é a de "deixar o assunto para ver os meios de tratá-lo" (cf. III, 8, p.926). ${ }^{17}$ Obviamente, é pelo viés e perspectiva da "aptidão" para a conversação que ali ele surge. Entretanto, a mudança de interesse que se opera ao longo do arrazoado montaigniano sobre a conversação - passa-se do

\footnotetext{
${ }^{17}$ O que parece alinhar os esclarecimentos do exercício da conversação expostos no capítulo ao estudo de "uma forma de falar" e a apresentação de regras "para a direção do espírito", tal como já indicava a leitura de J. Y. Pouilloux em seu Lire les "Essais" de Montaigne. No entanto, o privilégio que se dá à crítica epistemológica nesta leitura, ao "colocar a questão da desordem, de suas razões e de suas funções" (cf. idem, ibid., p.45 et passim), bem como a desqualificação radical de toda interpretação que busca uma ordem oculta e um conteúdo de saber nos Ensaios, transformando-os num procedimento de acúmulo de enunciados ideológicos como "matéria do discurso crítico", nos parecem, de algum modo, incompatíveis com o imperativo da "ordem" que se exprime de modo tão enfático neste mesmo capítulo. Como veremos, a questão da ordem na condução do pensamento é ...
} 
cuidado com as matérias para um cuidado com a maneira que é preciso caracterizar - claramente franqueia os limites mais estreitos desta disciplina que regula a manière du dire em uma prática bastante específica e em grande medida pertencente ao âmbito da cortesania. Minha hipótese é a de que flagramos aí uma espécie de conversão para o âmbito da "maneira" que se pode aplicar ao conjunto da obra que vai se constituindo no embate dialogado de seu autor com o mundo e com os livros, ou seja, com o todo da experiência que vai sendo, de algum modo, consignada nos Ensaios, ao longo do tempo de sua composição. Acredito que um passo na compreensão do sentido desta "conversão" é dado quando se estabelece, num primeiro momento do nosso texto, a relação que se deve ter com as diversas opiniões com que se defronta quem entra em conversação. Montaigne nos fala, em primeira pessoa, de sua própria atitude. É bem o início de seu tratamento do tema da conversação, já que se deixou para trás nesta altura somente um prólogo:

“J'entre en conference et en dispute avec grande liberte et facilité, d'autant que l'opinion trouve en moy le terrein mal propre à y penetrer et y pousser de hautes raçines. Nulles propositions m'estonnent, nulle creance me blesse, quelque contrarieté qu'elle aye à la mienne. II n'est si frivole et si extravagante fantasie qui ne me semble bien sortable à la production de l'esprit humain. Nous autres, qui privons nostre jugement du droict de faire des arrests, regardons mollement les opinions diverses; et, si nous n'y prestons le jugement, nous y prestons aiséement l'oreille. Où l'un plat est vuide du tout en la balance, je laisse vaciller l'autre, sous les songes d'une vieille." 
[Entro em conversação e em disputa com grande liberdade e facilidade, porquanto a opinião encontra em mim terreno impróprio para aí penetrar e aí fincar profundas raízes. Nenhuma proposição me espanta, nenhuma crença me fere, por contrária que seja a minha. Não há tão frívola e tão extravagante fantasia que não me pareça bem possível de sair da produção do espírito humano. Nós outros, que privamos nosso julgamento do direito de fazer arrestos, olhamos molemente as opiniões diversas; e, se não Ihes emprestamos o julgamento, emprestamos-Ihes facilmente a orelha. Onde um prato está vazio por completo na balança, deixo oscilar o outro, sob os sonhos de uma velha.] (III, 8, p.923)

Embora longa, a citação nos é útil, pois condensa o essencial da postura intelectual que habilita ao bom desempenho do homem de conversação. A "liberdade e facilidade" na conference, vemos, assentam no desenraizamento das opiniões operado neste passo, claramente, por uma vinculação ao Ceticismo. Tanto a imagem da "balança" como a afirmação de que "priva o julgamento do direito de dar sentenças" nos parecem indícios suficientes. Mas, aqui nos importa discutir o que esta vinculação ao Ceticismo - se autenticamente pirrônico ou não, deixemos de julgar por agora - produz em termos do exercício da conversação (e, daí, em termos da manière que se estende à confecção do próprio livro). Dois pontos são de destacar. A "ignorância" que se instaura a partir da crítica cética, primeiro, habilita a ouvir as mais diversas, contrárias, e mesmo disparatadas "opiniões", de maneira calma (mollement), sem "espanto" e sem "ofensa". Não há "frívola e extravagante 
fantasia" que o homem de conversação não considere como produção possível do espírito e a que não possa "emprestar a orelha", ele que não lhe "empresta o julgamento", ou seja, ele que não decide sobre sua verdade ou falsidade. Além disso, a mesma "ignorância" permite que ele reconheça nestas "opiniões", ainda que pouco, algum peso: "Pour moy, eles emportent seulement l'inanité, mais eles l'emportent" [Por mim, superam somente a inanidade, mas a superam] (ibid.). Longe de barrar a curiosidade, mantém-no aberto e atento às possíveis produções do espírito humano, e as correções que podem proporcionar. E assim, posiciona-se como que entre dois extremos viciosos, pois muitos que tentam evitar a "superstição", afirmando peremptoriamente a inverdade de tais "insanidades" (ravasseries), acabam presunçosamente incorrendo no vício oposto da "obstinação" (opiniastreté): portam-se como possuidores de uma verdade incontestável.

Logo, o que esta postura "cética" favorece é a abertura para o exercício de uma conversa em que haja "contradição dos julgamentos": "Les contradictions donc des jugemens ne m'offencent ny m'alterent; eles m'esveillent seulement et m'exercent" [As contradições, pois, dos julgamentos não me ofendem nem me alteram; despertam-me somente e exercitam-me] (ibid., p. 924). Contradição que Montaigne encara como instrução, pois, segundo nos descreve, as repreensões rudes e ásperas que recebe "despertam sua atenção, não sua cólera" (cf. ibid.). ${ }^{18}$ Flagramos aqui mais um efeito de seu desapego em

${ }_{18}$ Cícero, na breve nota que dedica à conversação em Dos deveres, já prescrevia para a conversação que se evitassem excessos da alma que não se curvassem à razão - banindo a 
relação às próprias opiniões e crenças, já que o fato de não incorrer no páthos colérico permite manter "a verdade como a causa comum" dos que conversam e disputam. ${ }^{19}$ Em outras palavras, é porque, de saída, Montaigne não assume sua própria posição pessoal num debate como a portadora da razão e da verdade, ou seja, não se obstina como o faz um opiniastre, que pode aceitar ser contradito em nome de uma "verdade impessoal" que se investiga e busca.

Isto é tudo o que Montaigne não encontra nos "homens do seu tempo", com os quais coteja sua própria atitude: por não terem a "coragem de sofrer a correção", eles não têm igualmente a "coragem de corrigir" e "falam sempre com dissimulação em presença uns dos outros" (cf. ibid.). Dissimulação que Montaigne, em princípio, exclui do regime de sua conference:

cólera, a cupidez, a preguiça etc. -, mesmo quando se emprega um tom mais firme nas repreensões; sobretudo a cólera é de evitar, pois, como justifica o orador, "sob o império dela nada se faz com justiça e razão" (cf. Cıc. De off. I XXXVII, 136-7.)

${ }^{19}$ Que não nos engane esta referência tão enfática à verdade. Ela não invalida a "profissão de fé" no ceticismo a que aludimos ainda há pouco. E o homem continuará, como nos diz Montaigne páginas adiante, encerrado em uma "escole d'inquisition", e todo discurso que se tece não abandona esse regime, por assim dizer, problemático, quando pensado da perspectiva da verdade a que se visa, já que os múltiplos "exercícios do juízo", de fato, jamais alcançam possuíla. Ora, certamente não há para Montaigne enunciado acerca das matérias exploradas, no curso de uma conversa ou no livro, que não possa ser revisto, e que o próprio autor por vezes não revê. O que, no mais, circunscreve e define a própria dýnamis antithetiké dos homens aptos para a conference, sua capacidade de conferir igual peso aos dois lados da contradição e obter assim o estado de "suspensão" que se segue à falta de critério para escolher entre eles. O que, em suma, acaba por reduzir todo discurso ao domínio da opinião. 
"J'ayme, entre les galans hommes, qu'on s'exprime courageusement, que les mots aillent où va la pensée. II nous faut fortifier l'ouie et la durcir contre cette tandreur du son ceremonieux des paroles."

[Gosto, entre os gentis-homens, de que se exprimam corajosamente, de que as palavras cheguem onde vai o pensamento. É-nos preciso fortalecer o ouvido e 0 endurecer contra a ternura do som cerimonioso das palavras.] (ibid.)

Vemos, então, que a conversa que aqui se elogia abertamente tem na "contradição dos julgamentos" uma das principais cláusulas de seu "decoro": “Elle [=la conference] n'est pas assez vigoureuse et genereuse, si ele n'est querelleuse, si ele est civilisée et artiste, si ele craint le hurt et a ses allures contreintes" [Ela não é assaz vigorosa e generosa, se não for querelante, se for civilizada e artificiosa, se temer o choque e tiver seus passos constrangidos] (ibid.). Ela se desdobra e perfaz entre amigos que vigorosa e generosamente se entre-corrigem em suas opiniões e condutas, deixando, como nos diz o ensaísta, "suas palavras [irem] onde [vão seus] pensamentos". Neste regime de conversação, como afirma André Tournon, "as complacências mútuas das conversas de salão não são admitidas" ${ }^{20}$, nenhum descompasso entre o que se pensa e o que se diz, entre o lógos e a léxis, tem lugar. Não há espaço nenhum para a mentira, a adulação e a dissimulação. ${ }^{21}$

\footnotetext{
${ }^{20}$ Tournon, op. cit., p. 167.

${ }^{21}$ No entanto, se este é um "regime", por assim dizer, ideal da conversação, visto que nele ocorre o encontro de interlocutores aptos, este não é o exclusivo "regime" em que pensa
} 
Esta postura destacada em relação à verdade das próprias opiniões e que, portanto, aceita "pacificamente" pô-las à prova, fica ainda mais evidente no desapego de Montaigne para com a "vitória" na disputa. O que mostra que não só a adulação e dissimulação - o "uníssono" que era qualificado como tedioso desde o início do capítulo - são recusadas, mas também uma postura que buscasse a qualquer custo a vantagem e a vitória no debate:

"Noz disputes devoient estre defendues et punies comme d'autres crimes verbaux. [...] Nous n'aprenons à disputer que pour contredire, et, chascun contredisant et estant contredict, il en advient que le fruit du disputer c'est perdre et aneantir la verité." [Nossas disputas deveriam ser proibidas e punidas como outros crimes verbais. [...] Aprendemos a disputar só para contradizer, e, cada um contradizendo e sendo contradito, acontece daí que o fruto da disputa é perder e aniquilar a verdade.] (ibid., p.926)

As condições em que o diálogo deve-se dar, portanto, são definidas entre estes extremos ou desvios. Ainda quanto à possível esperança de vitória no debate, respondendo a uma objeção que se poderia fazer a sua postura calma e corajosa tanto em corrigir como em sofrer a correção, como se se tratasse de segurança por acreditar-se dotado de força - a força e sabedoria de um

Montaigne, estando sempre aberta, para os que "vive[m] entre os vivos", a possibilidade de um encontro menos "vigoroso e generoso". O início mesmo do texto distingue claramente duas possibilidades de encontros (cf. III, VIII, p.923, em que fala da "comunicação com os espíritos vigorosos e regrados, distinguindo-a do "comércio e frequentação com os espíritos baixos e doentios"). 
Sócrates - para triunfar gloriosamente das contradições a cada vez que elas se apresentam, o ensaísta, reiterando sua preferência pela frequentação dos que o maltratam a dos que o temem, constrói para si a posição humilde de quem aceita a contradição corretora. Alega que qualquer "opinião de preeminência e desdém pelo adversário" tornam o "sentimento assaz delicado" diante da contradição, o que impede exatamente de aceitar "as oposições que o retificam e recompõem". E o movimento mesmo da argumentação se encerra com uma consideração da vitória que se poderia obter diante de um ou outro oponente:

"Je me sens bien plus fier de la victoire que je gaigne sur moy quand, en l'ardeur mesme du combat, je me faicts plier soubs la force de la raison de mon adversaire, que je ne me sens gré de la victoire que je gaigne sur luy par sa foiblesse."

[Sinto-me bem mais confiante na vitória que conquisto sobre mim quando, no ardor mesmo do combate, eu me faço dobrar sob a força da razão de meu adversário, do que me sinto agraciado pela vitória que conquisto sobre ele por sua fraqueza.] (ibid., 925)

A conference, assim, define-se como um exercício em que, de saída, todas as proposições se veem igualadas e reduzidas ao domínio opinativo, instaurando as condições de um livre exame, de uma busca desinteressada da verdade, em que não importa tanto a vitória que se obtém na matéria, mas a conduta que se tem durante o seu transcorrer. Todo seu jogo se joga no campo da "forma", ou 
da bela manière dos "conferencistas". É nesse campo que se avalia a sua vis, a sua "força", ou, em termos montaignianos, a sua suffisance:

"Quelle plus grande victoire attendez vous, que d'apprendre à vostre ennemy qu'il ne vous peut combatre? Quand vous gaignez l'avantage de vostre proposition, c'est la verité qui gaigne; quando vous gaignez l'avantage de l'ordre et de la conduite, c'est vous qui gaignez."

[Que maior vitória esperais que ensinar ao seu inimigo que ele não vos pode combater? Quando ganhais a vantagem de vossa proposição, é a verdade que ganha; quando ganhais a vantagem da ordem e da conduta, sois vós que ganhais.] (III, 8, p.927)

Como se vê, a maior vitória não é referente ao "objeto" tomado para disputar, não se dá no plano das "matérias". Pois, ela pode ocorrer mesmo quando se perde a vantagem da proposição, mesmo quando a tese que se sustenta é refutada. A lição que se mostra ao adversário é de "ordem e conduta" no tratamento das matérias, qualidades que aderem - diferentemente da verdade, atributo das proposições - aos "sujeitos". Pois em grande medida o que a conversa deve produzir é a correção da "impertinência" dos homens, tal como Montaigne entende a tarefa assumida por Sócrates em Xenofonte e Platão:

“II m'est advis qu[e] [...] Socrates dispute plus en faveur des disputants qu'en faveur de la dispute; et, pour instruire Euthydemus et Protagoras de la connoissance de leur impertinence plus que de l'impertinence de leur art. II 
empoigne la premiere matiere comme celuy qui a une fin plus utile que de l'esclaircir, assavoir esclaircir les esprits qu'il prend à manier et exercer."

[Sou de parecer que [...] Sócrates disputa mais em favor dos que disputam do que em favor da disputa; e para instruir Eutidemo e Protágoras acerca do conhecimento de sua impertinência mais do que da impertinência de sua arte. Ele empunha a primeira matéria como quem tem um fim mais útil do que a esclarecer, a saber, esclarecer os espíritos que ele toma para manejar e exercitar.] (ibid., p.927-8)

Este Sócrates já não ensina o erro de opinião sobre as matérias, realizando o parto que traz à luz aquele que irá engajar-se no estudo das realidades verdadeiras, mas o que imporá ao espírito a exigência interna de ordenação. Ao alegar que Sócrates disputa "mais em favor dos que disputam do que em favor da disputa", e para instruir sobre a impertinência deles e não de sua arte, o texto já demonstra o desvio de atenção das "matérias" para a "maneira". Já não se trata de ensinar que a tese sustentada por qualquer um dos interlocutores não dá conta de responder ao problema que se pôs de início. Ou seja, não se trata de acusar uma impertinência no que se diz sobre a matéria e de reconhecer que se estava em erro no plano do juízo formulado sobre ela. O que seria apontar simplesmente uma "impertinência da arte". O que se ensina a conhecer é a impertinência dos "esprits", sua tolice e desordem. É o reconhecimento de um erro que assenta no sujeito mesmo, em sua forma de condução do pensamento, 
e não no juízo que formula sobre as coisas. A suma de toda esta discussão nos é oferecida um pouco adiante:

"L'agitation et la chasse est proprement de nostre gibier: nous ne sommes pas excusables de la conduire mal et impertinemment; de faillir à la prise, c'est autre chose. Car nous sommes nais à quester la verité; il appartient de la posseder à une plus grande puissance. [...] Le monde n'est qu'une eschole d'inquisition. Ce n'est pas à qui mettra dedans, mais à qui faira les plus belles courses."

[A agitação e a caça é propriamente de nossa competência: não somos escusáveis por conduzi-la mal e impertinentemente; falhar quanto à presa é outra coisa. Pois nascemos para buscar a verdade; pertence possuí-la a uma maior potência. [...] $O$ mundo não é senão uma escola de inquisição. $O$ que não é para quem [acertar o alvo], mas para quem fizer as mais belas corridas.] (ibid., p.928)

Poucos textos assinalam com tanta precisão que a tarefa conferida ao homem é a da busca, que seu horizonte é o da zétesis. Mas o fato de que se trata de uma busca ordenada, pertinente, bela, mostra, ainda uma vez, que os cuidados e o zelo com o discurso deslocaram-se da adequação, dogmática, suposta que este poderia vir a manter com as próprias coisas, para o domínio da manière du dire. O que importa passa a ser não mais a "captura da presa", mas a bela "condução da caça". Desloca-se o télos da conversa, que não mais tem por alvo a "obtenção da presa", e sim, o próprio desempenho hábil de seu exercício, o que a menção à "beleza das corridas" parece, metaforicamente, 
confirmar. Ainda que, entre as condições para o bom exercício da conversa, mantenha-se, como dissemos acima, "a verdade como causa comum", não se trata mais exatamente de querer obtê-la, mas de instalar-se tranquilamente no domínio da busca e exercê-la com graça. ${ }^{22}$

Tanto é assim que Montaigne está apto para dissociar o "verdadeiro" da "ordem e pertinência", o "falso" de seus contrários: "Autant peut faire le sot celuy qui dict vray, que celuy qui dict faux: car nous sommes sur la maniere, non sur la matiere du dire." [Tanto pode agir tolamente quem diz o verdadeiro, como quem diz o falso: pois estamos na maneira, não na matéria do dizer] (ibid.). Note-se, de passagem, que esta conclusão, formulada de forma intencionalmente ambígua, pode se aplicar não só à discussão sobre a conversação, como também referir-se obliquamente ao conjunto dos Ensaios, que efetivamente não abordam as matérias tentando estabelecer um saber seguro e certo sobre elas, mas somente as aborda e trata no intuito de exibir e

\footnotetext{
${ }^{22}$ Passa-se de um exercício que tentava avançar na conquista da verdade, para um que só dá por garantias a mestria e beleza na execução de seus passos, sem mais, e o prazer e utilidade que daí decorre, para si e para os outros (sobre a conversação como "exercício das almas, sem outro fruto", cf. III, 3, "Des trois commerces", p.824). Da utilidade, restaria dizer que ela é, não só do âmbito da própria ordenação do espírito, se pudermos entender a conversação como formadora do juízo, participando da tarefa da institution e estendendo-se no tempo, como também da correção de opiniões, sempre provisórias, e condutas que venham a ser acusadas pelo interlocutor no curso de uma conversa. Vale lembrar que a tarefa assinalada a conference é também moral, combate, como obra de caridade, os vícios que se acham enraizados no amigo interlocutor.
} 
ostentar a "maneira" do nosso Ensaísta manejá-las e desenvolvê-las em seus exercícios do juízo, como tão bem nos instrui o início desenvolto do capítulo II, 10, "Dos livros", em que fala de sua falta de competência para tratar as matérias em que ensaia suas "faculdades naturais", e de que eu lembraria aqui apenas o arremate final: "Que não se preste atenção às matérias, mas à maneira (façon) que Ihes dou" (p. 408). Atitude de leitura que Montaigne, mais do que espera, prescreve, e que se aproxima inteiramente da maneira como ele mesmo lê, segundo nos diz o mesmo "De l'art de conferer":

"Et tous les jours m'amuse à lire en des autheurs, sans soin de leur Science, y cherchant leur façon, non leur subject. Tout ainsi que je poursuy la communication de quelque esprit fameux, non pour qu'il m'enseigne, mais pour que je le cognoisse."

[E todos os dias me divirto em ler nos autores, sem preocupação com sua ciência, aí buscando sua maneira, não seu assunto. Da mesma forma que procuro a comunicação de algum espírito famoso, não para que ele me ensine, mas para que eu o conheça.] (ibid., grifo meu)

Tendo assim deixado para trás a preocupação com a verdade das matérias, toda atenção se converte para os "verdadeiros" traços distintivos do espírito, que são os "modos" que distinguem o mero dizer, conquanto ocasionalmente verdadeiro, do dizer bem e com pertinência: "Tout homme peut dire veritablement; mais dire ordonéement, prudemment et suffisamment, peu 
d'hommes le peuvent" [Todo homem pode dizer verdade; mas dizer de modo ordenado, prudente e suficiente, poucos homens o podem] (ibid.).

No entanto, tal "conversão" não significa para Montaigne absolutamente que se dê relevo a um cuidado que poderíamos qualificar como puramente "formal", um cuidado que é desqualificado como "meio escolástico e artificial" (ibid., p.926) ${ }^{23}$, nem inverte a precedência estabelecida pelos clássicos das coisas (res) sobre as palavras (verba), do cuidado com as concepções e ideias, ou seja, da invenção, sobre o cuidado com a disposição e, sobretudo, a elocução do discurso. ${ }^{24} \mathrm{O}$ ensaísta nos fala de "meio natural, de um são

${ }^{23}$ Mas tal desqualificação deve ser pensada na chave de uma valorização da "formação do entendimento", contra a cultura da "memória", que se atém a produzir discursos que costuram citações alheias, sem apreender sua significação mais profunda, sem se apropriar verdadeiramente da força destes discursos. Montaigne fala de um "uso" que se faz das "ciências" por parte dos sçavants, não desqualificando o "saber" enquanto tal, que conhece um "verdadeiro uso" (cf. ibid., p. 927).

${ }^{24}$ Tal precedência se codifica e fixa, por exemplo, em Horácio, na "Epístola aos Pisões", também conhecida como Arte Poética, tendo sua expressão condensada na fórmula: rem provisam, verba sequentur (HoR. Ars Poetica, 311: Verba provisam rem non invita sequentur [As palavras espontaneamente seguirão as ideias bem concebidas]); a discussão perpassa vários tratados de retórica da antiguidade, que dão mais relevo ao trabalho da "invenção" que ao da "disposição" e "elocução" dos discursos, subordinando estas tarefas àquela. (Sobre a distinção entre estas duas tarefas cumpridas pelos oradores, cf. CIC. Part. 1, 3: "C.F. Em quantas partes deve ser dividida toda doutrina do discurso? [...] C.P. Primeiro no vigor (vis) mesmo do orador [...]. C.F. Em que assenta o próprio vigor? C.P. Em casos (rebus) e em palavras (verbis). Mas tanto casos como palavras devem ser inventoriadas e colocadas. Propriamente, porém, diz-se invenção para os casos, elocução para as palavras."; id. De inv. I 7, 9; Rhet. Her. I 3.) 
entendimento" (ibid.). Este é um ponto crucial, e ao mesmo tempo difícil, para a compreensão do "De l'art de conferer", pois no momento mesmo em que acreditamos trocar a ordem de preocupações, passando do âmbito da adequação do discurso às coisas, para o de sua ordenação interna por regras codificadas por uma técnica, já que se trata agora da "maneira", o texto nos remete novamente para o âmbito das "matérias", das coisas tratadas, das concepções e ideias expostas, uma vez que são elas que impõem a ordenação aos espíritos. Melhor dizendo, é, por um lado, da escolha da matéria adequada à força dos "engenhos", que, ademais, deve ser una, e, por outro, da "compreensão" que os interlocutores, na medida em que são aptos (suffisantes), têm das matérias tratadas que o discurso haure sua "ordem". É à "força" das concepções deles, resultado de um zelo e cuidado - aliás, bem sucedido - com a institution, que o arrazoado montaigniano nos remete. E, portanto, à "suficiência" (suffisance ${ }^{25}$ ) de uma teste bien faicte, que garante por si só a unidade e a pertinência da discussão, em uma palavra: o entendimento.

Com isso, tocamos já no segundo ponto anunciado no início: a questão da "ordem" (ordre) que articula o discurso na conversa, e, por que não, no livro,

\footnotetext{
${ }^{25}$ A suffisance é amplamente tratada por Montaigne em toda segunda metade de nosso texto, onde se ensina a reconhecer, por assim dizer, duas de suas contrafações: as suffisances d'apparences, aspectos de que se reveste todo aquele que é, sem verdadeiro mérito, alçado pela fortuna a posições eminentes; as suffisances estrangeres, alegações de peso que são avançadas no curso de uma conversa, mas de que se desconhece amiúde o verdadeiro alcance e as implicações. Não vamos nos estender sobre elas aqui. Vamos, antes, nos deter no problema da "ordem" tal como ele surge ainda no primeiro momento de nosso texto.
} 
agora avisados de que esta ordem não se concebe como um espelhamento da ordem das coisas mesmas no discurso. Ainda assim, é a penetração das concepções das "coisas" que assegura uma ordem. ${ }^{26}$ Como isso se dá, é o que tentaremos mostrar brevemente no que segue.

A "ordem", podemos dizer, é um dos termos que integram as qualidades da manière montaigniana, ao lado da "prudência" e da "suficiência", de que, no nosso ver, a "ordem" depende. Há outros elementos, como a força, a graça ou a sutileza dos argumentos, mas que são relegados a um segundo plano. A "ordem" é o predicado privilegiado pelo ensaísta na conversação, condição necessária e suficiente de um desempenho excelente. A construção da "ordem", por sua vez, pressupõe duas coisas: a unidade da matéria tratada e, se não a ciência desta matéria, uma "ciência" de tratá-la. Esta "ciência" de tratar um assunto (subject) não pode, contudo, ser confundida com uma técnica ou arte, nem, exatamente, com um método. Embora Montaigne advirta sobre

\footnotetext{
${ }^{26}$ Cabe, contudo, enfatizar que, evidentemente, não se pode entender esta aplicação às coisas ou concepções senão como uma operação que se põe no plano das fantasies - nunca num sentido dogmático da apreensão de alguma verdade sobre as coisas, mas no da capacidade de produzir discursos verossímeis sobre elas -, num processo de assimilação e digestão que demanda avaliar o seu peso, inspecionar suas conexões, discernir articulações, compreender seus pressupostos e implicações, apropriando-se de seu sentido, e tornando próprio o que era alheio, o que permite dar ordem ao discurso - a ordem inscrita no próprio encadeamento das concepções, e não imposta de fora através de preceitos das técnicas de produção discursiva - e pertinência ao tratamento das matérias. Ordem das concepções que vão se ligando e encadeando num discurso, cujos nexos são governados e costurados pela noção de à propos.
} 
procedimentos que adota ao conversar, ela essencialmente depende, como veremos, de uma educação (institution) zelosa e assídua, que proporcione e fomente o exercício do julgamento, a penetração aguda nas diversas ciências, que Ihes descobrem a fraqueza e precariedade, e, por fim, de experiência. $O$ resultado não é uma habilidade técnica, mas uma espécie de "domínio" em relação às matérias de discurso tomadas da tradição que Montaigne chama precisamente de suffisance. Retomemos a análise de alguns passos do nosso capítulo para tentar elucidar estes pontos.

Um primeiro fato a notar quando nos voltamos para este problema da "ordem" que costura os discursos - e, por que não, os ensaios - é que a discussão sempre traz à tona uma questão central para os vários projetos intelectuais da Renascença ${ }^{27}$ - central, por conseguinte, para Montaigne -, qual seja, a do "pedantismo". O tolo (sot) que Montaigne satiriza longamente no "De l'art de conferer", em seus múltiplos aspectos e formas tipicamente construídos, não é senão um legítimo representante desta incorreta relação com o saber e as letras, que ameaça o fim preciso da imitação reproposta dos antigos. Espécie de figura reguladora interna de uma cultura que cuida para não desgarrar de seus propósitos mais elevados. Não é outra a função que ele ocupa no nosso texto. Ele é o negativo de que se extrai a instrução par disconvenance ou par

${ }^{27}$ Não está tão distante disso, a invectiva que Petrarca move contra os velhos dialéticos em suas Cartas das coisas familiares (cf. De rerum familiarium I, 7: contra senes dyalecticos). Aliás, nisso ele é tanto quanto Montaigne herdeiro de Sêneca em suas Epístolas morais à Lucílio, que amiúde se volta contra as preocupações da "lógica" que desviam a atenção da urgência dos problemas morais (cf. SEN. Epistulae ad Lucilium, LIX). 
contrariété. E o é, sobretudo porque conduz seu pensamento de maneira "impertinente", sem a qualidade que garante a "ordem" e, daí, o bom exercício da busca, as correções e o entendimento.

Ora, se o discurso para o ensaísta não pode ter garantias de não se desgarrar, tomadas a uma verdade objetiva sobre as coisas, não se renuncia por isso a garantia da pertinência das falas que são trocadas ao longo da conversa. Esta pertinência, contudo, de forma alguma se constrói a partir de regras externas $^{28}$ de condução do pensamento e produção do discurso, mas internamente, quando as trocas verbais "referem-se pertinentemente à questão". ${ }^{29}$ Com os homens "vigorosos", a "ordem e pertinência" abrem o campo do entendimento mútuo, favorecendo uma quase fusão das "imaginações" dos interlocutores:

\footnotetext{
${ }^{28}$ A crítica da regulação externa do pensamento e do discurso, bem como, em contrapartida, a afirmação dos "meios naturais de um são entendimento", fazem eco, em larga medida, ao modos dos autores humanistas invectivarem disciplinas como a dialética, assimilada no tempo a disputatio escolástica, e mesmo a própria retórica. Não se trata de uma negação tout court do valor das disciplinas do trivium, mas do restabelecimento de seu lugar, como meio, e não fim de toda instrução. Em Montaigne, o acento recai sobre a relação "venal" com as Musas, incompatível com as aspirações de um fidalgo bem-nascido que não quer confundir-se com os faiseurs de livres, ou com os que fazem das Letras profissão, meio de vida.

${ }^{29}$ Cf. Tournon, ibid., p.167. Que a "ordem" que se demanda tem que ver com "pertinência", a própria insistência no emprego do termo contrário o atesta (cf. III, VIII, p.927: “... de leur impertinence...”; ibid.: “... de l'impertinence de leur art”; ibid., p.928: “... conduire mal et impertinemment”; ibid., p. 932: “... parler impertinemment”).
} 
“[...] quand je debats contre un homme vigoureux je me plais d'anticiper ses conclusions, je luy oste la peine de s'interpreter, j'essaye de prevenir son imagination imparfaicte encores et naissante (l'ordre et la pertinence de son entendement m'advertit et menace de loing) [...]."

[(...) quando debato contra um homem vigoroso, me apraz antecipar suas conclusões, poupo-Ihe o esforço de se interpretar, experimento antecipar sua imaginação imperfeita ainda e nascente (a ordem e a pertinência de seu entendimento me adverte e ameaça de longe) (.....”(III, 8, p.936)

Isto é tudo de que o tolo (sot) não é capaz, nem, ao conversar, propicia ao seu interlocutor. $O$ texto montaigniano, precisamente, pede licença para desviar-se do assunto ("subject") para ver "o meio de tratá-lo" por ocasião da entrada em cena desta figura que permite delinear, se bem que pelo avesso, os contornos da "ordem". Ele em grande medida identificado aos sçavants, homens instruídos, porém, obstinados e pedantes, que calcam o seu saber na memória e no empréstimo e imitação servil das autoridades, bem como na subserviência aos preceitos das artes. ${ }^{30}$ Tantos traços de uma "indigestão" intelectual e de

${ }^{30} \mathrm{O}$ que de modo nenhum quer dizer, no contexto histórico em que Montaigne escreve, um desconhecimento ou mera desconsideração dos preceitos e dos modelos a imitar. Seria anacrônico afirmar tal independência. Quer isto dizer, ao contrário, que nosso autor propugna por um domínio hábil das regras da arte e sabe a ocasião oportuna de desprezá-las, bem como imita rivalizando com seus modelos, e, portanto, reclama o status de "autor". Mesmo afirmando ampla liberdade e independência no que diz, é inegável que a maior parte do tempo nosso autor trilha caminhos antes trilhados ou apontados por outros. É inegável igualmente, desde o 
uma sujeição ao "alheio" em detrimento do "próprio" que nosso autor insistentemente rechaça e que aponta como causa da desordem na conduta dos debates. ${ }^{31}$ Daí, a presença da "ordem" parecer, antes, apanágio do "rústico" que

admirável recenseamento de fontes feito por Villey, que o texto de Montaigne se constrói num diálogo cerrado com os autores que compulsa e lê. Em suma, está em jogo aqui, segundo penso, não a afirmação de uma autonomia para o discurso que se produz, mas algo que havia sido recentemente reproposto pelos italianos e que responde pelo nome de Sprezzatura e que recolhe as lições de uma antiga tradição, entre os latinos, e em Cícero em particular, relativa a tópica da "negligência diligente". É preciso não perder de vista a crítica ao artifício, movida pelo ensaísta ao longo dos três livros dos Ensaios, com o intuito de criar um éthos favorável por meio de seu discurso; todavia, sem esquecer, igualmente, que esta mesma crítica é preceituada e compõe um repertório de tópicas que tornam o discurso montaigniano verossímil, ou seja, dá-lhe uma eficácia persuasiva, pelo simples fato de se apoiar numa premissa reputada no tempo em que escreve. Portanto, não se trata de um simples desprezo pelas regras de arte, mas de uma obediência ao preceito maior de "naturalizar a própria arte". Isto não implica em anular a crítica da mentira e da dissimulação, mas em dar-lhe seu correto acento, que não exclui um uso da dissimulação dentro do que a tratadística do séc. XVII chamará de "dissimulação honesta".

${ }^{31}$ A oposição entre o alheio e o próprio é fundamental em Montaigne, no entanto, deve ser bem compreendida. Não se trata de uma afirmação pura e simples das produções naturais do próprio espírito, mas de um processo de "assimilação" que torna próprio o que era saber ou lição alheia, e que se constrói, sobretudo durante a institution. É de lembrar que boa parte da educação se faz pelo comércio com os livros, segundo o "Da educação das crianças". O que Montaigne critica é a imitação servil dos faiseurs de livres e a reprodução de memória das lições dos clássicos, em prol de uma relação que chegue a forjar entendimento e julgamento seguros sobre o que aqueles discutem, não parando na mera repetição verbal, mas chegando aos atos, incluindo aí os que dão vida a uma nova obra. 
dos "instruídos e doutos", pois estes é que se pautam pelos "meios naturais" de um "são entendimento" ${ }^{32}$ Leiamos:

“L'ordre qui se voit tous les jours aux altercations des bergers et des enfans de boutique, jamais entre nous. S'ils se detraquent, c'est en incivilité; si faisons nous bien. Mais leur tumulte et impatience ne les devoye pas de leur theme: leur propos suit son cours. S'ils previennent l'un l'autre, s'ils ne s'attendent pas, aumoins ils s'entendent. On respond toujours trop bien pour moy, si on respond à propos."

[Ordem que se vê todos os dias nas altercações dos pastores e dos meninos de oficina, jamais entre nós. Se eles se atropelam, é por incivilidade; também nós o fazemos. Mas seu tumulto e impaciência não os desvia do tema: o propósito deles segue seu curso. Se se antecipam um ao outro, se não esperam [sua vez], ao menos eles se entendem. Responde-se muito bem para mim, se se responde à propósito.] (ibid., p.925)

\footnotetext{
${ }^{32}$ Que se cuide, no entanto, de não lermos a passagem de modo assaz "positivo". O contexto é claramente de vitupério, logo, a oposição entre "rústico" e "douto" se faz como estratégia de amplificação das qualidades que Montaigne defende para a conversa. Não se afirma a superioridade do vulgo de modo efetivo. Isto seria difícil de conciliar com um passo posterior em que Montaigne se vê irritado com a tolice das respostas de seus serviçais (cf. ibid., p.928). Seria também incompatível com o elevado sentido que tem a instrução que devem receber os homens aptos para a conversa, altamente "instruídos", no bom sentido para Montaigne (cf. ibid., p.937-8). O "douto" só é ridicularizado quando representa um desvio do uso das "ciências" e dos fins a que visa a educação.
} 
Notamos aqui como à "civilidade" que observe regras de boas maneiras no trato mútuo entre os homens não pertence o que é essencial para a produção da ordem. ${ }^{33} \mathrm{E}$ ao lado disso, o que a "incivilidade" dos "pastores e meninos de oficina", em seu "tumulto e impaciência", não exclui por sua vez: o

${ }^{33}$ É preciso distinguir uma crítica da adulação, que perpassa todo "De l'art de conferer", e os Ensaios, da crítica que se move contra os "artifícios" das artes que regulam a produção discursiva. A primeira tem como alvo a dissimulação e a mentira que levam os homens a não dizerem tudo o que pensam, ou seja, promovem o descompasso entre o que se diz e o que, de fato, se pensa. Atitude perniciosa para o loyaliste Montaigne, como atesta enfaticamente um capítulo como o "Do desmentir" (II, 18). Já a segunda, pertence a uma desqualificação das técnicas de produção de discurso enrijecidas, quando estas reclamam uma anterioridade das regras e preceitos, bem como das categorias com que ordenam os assuntos, o tratamento das matérias, que entrava e bloqueia, em seu artificialismo, o exercício do pensamento e do julgamento, sobretudo porque se ocupam com o inessencial e são típicas dos "esprits foiblement fondez" para Montaigne, ou seja, dos pedantes que não penetraram na compreensão das questões de que se arriscam a falar. Trata-se, antes, de um restabelecimento das prioridades, não de uma negação das regras. De seu domínio, não de uma subserviência ao que ditam os preceitos codificados nos tratados. Basta notar como Montaigne insiste num exercício "regrado" do espírito, ditado por "meios naturais", não rompendo de todo com a exigência de regramento. De resto, quando Montaigne, em nosso mesmo "De l'art de conferer", nos fala de como se deve ler um autor e da dificuldade de fazê-lo, são as mesmas categorias da elocução e da invenção das "artes" que ele pede para julgar: "Mais d'entreprendre à le [um autor como Vergílio, por exemplo] suivre par espaulettes, et de jugement expres et trié vouloir remarquer par où um bon autheur se surmonte, par oú se rehausse, poisant les mots, les phrases, les inventions une apres l'autre, ostez vous de là." [Mas empreender segui-lo ponto por ponto, e com julgamento expresso e preciso querer apontar por onde um autor se sobressai, por onde se realça, pesando as palavras, as frases, as invenções uma após outra, eximi-vos de fazê-lo.] (ibid., p.937, grifo meu). 
prosseguimento do curso da conversa garantido pelo simples fato de que não se desviam do tema proposto, atendo-se a este nexo mínimo e suficiente que engendra a ordem do discurso: o nexo nomeado sucinta e modestamente pela expressão à propos.

Mas o que faz da disputa com o tolo uma conversa "tumultuada e desregrada" (trouble et des-reglée)? Montaigne alude a um movimento tempestuoso em direções contrárias que se desgarra do que trata e perde o que buscava:

"L'un va en orient, l'autre en occident; ils perdent le principal, et l'escartent dans la presse des incidens. Au bout d'une heure de tempeste, ils ne sçavent ce qu'ils cerchent."

[Um vai para o oriente, outro para o ocidente; eles perdem o principal, e descartam-no na multidão dos incidentes. Ao fim de uma hora de tempestade, não sabem o que buscam.] (ibid., p.926)

O problema com o tolo está, no geral, em sua incapacidade de manter a atenção no núcleo do assunto que trata, dispersando-se para o que é "marginal", incidental. A exigência, que vimos formulada inicialmente, da "contradição dos julgamentos", obrigava a falar da mesma coisa, mas não dizer a mesma coisa dela, e que, no limite, dissessem coisas contraditórias para que a conversa fosse proveitosa. Os tolos, segundo a acusação montaigniana, se desgarram uns dos outros e perdem a coesão da interlocução, mantida só quando se fala da mesma coisa e do que é essencial nela. Numa palavra, quando se mantém a unidade da 
matéria, sem variação que a comprometa. Daí o caráter contra-exemplar da sottise, de que Montaigne nos oferece um variado e irônico quadro, em que vemos vários traços deste comportamento desviante. ${ }^{34} \mathrm{O}$ essencial, no entanto, que devemos reter aqui desta denúncia da impostura dos tolos está no diagnóstico de suas causas. Este é objeto de um "excurso" em que dirige uma acerba invectiva contra o "uso que se faz das ciências e das letras", ${ }^{35}$ uso pedante e servil, que tem por causa certa "indigestão" intelectual, a que já aludimos acima e está na origem da inépcia do tolo.

Montaigne começa enunciando sua desconfiança quanto ao proveito para a vida que se poderia tirar das "ciências", em especial das que prometem ensinar a melhor pensar e discorrer:

“Or qui n'entre en deffiance des sciences, et n'est en doubte s'il s'en peut tirer quelque solide fruict au besoin de la vie, à considerer l'usage que nous en avons: [C] nihil sanantibus litteris? [B] Qui a pris de l'entendement en la logique? où sont ses belles promesses? [C] Nec ad melius vivendum nec ad commodius disserendum."

[Ora, quem não entra a desconfiar das ciências, e não fica em dúvida se delas se pode tirar algum sólido fruto para a necessidade da vida, ao considerar o uso

${ }^{34}$ Cf. ibid., o rol de comportamentos daqueles que não têm "nem passo nem porte que valham" e com os quais Montaigne se pergunta por que se por "em via de investigar o que é".

${ }^{35}$ Retomando brevemente, mas de maneira enfática, temas de que havia cuidado em seu primeiro livro, nos capítulos "Do pedantismo" (I, 25) e "Da educação das crianças" (I, 26). Além disso, poderíamos incluir a crítica ao conjunto das pretensas ciências de que o homem seria capaz, alvo da Apologia de Raymond Sebond. 
que delas fazemos: dessas letras que nada curam? Quem obteve o entendimento com a lógica? onde estão suas belas promessas? Não há nada [nelas]nem para viver melhor, nem para discorrer mais comodamente.] (ibid.; as citações latinas são, respectivamente, de SEN. Ep. LIX e CIC. De fin. I XIX)

Embora a citação de Sêneca mencione "letras", o seu alvo é mais precisamente a "lógica", ou seja, o conjunto das três disciplinas que compõem o trivium: gramática, dialética e retórica. São elas que pretendem regrar artificialmente a condução do pensamento e a produção do discurso. E também fica claro que Montaigne visa aqui, de maneira mais ampla, todo o conjunto das ciências, quando o cuidado com elas se torna independente de seus benefícios para a vida dos homens. A desconfiança e o desprezo testemunhados pelos sçavants e suas disciplinas - preferindo "as tavernas" às escholes de la parlerie para o filho aprender a falar - reforçada, na sequência de nosso texto, pela imagem do maistre ès arts - desafiado a despir seu "latim" e "não martelar Aristóteles inteiramente puro e inteiramente cru em nossos ouvidos" - figuram aqui certa aversão de Montaigne pelos "desvios" de que escapam, todavia, uma verdadeira relação com o saber e seu verdadeiro uso. A acusação montaigniana volta-se contra uma lide servil - que "emenda as bolsas, mas não as almas" -; lide com o saber que não se pôs a serviço da formação do jugement; formação que, ao contrário, levaria a forjar antes uma "cabeça bem feita" - uma teste bien faicte - que uma "cabeça bem cheia", conforme já propugnava a disciplina do 
"De l'institution des enfans". ${ }^{36}$ Sua crítica se volta claramente contra aqueles que assentam sua suffisance et valeur na "ciência" (sçavoir), que "submentem seu entendimento à memória", e não sabem nada senão o que tomam de empréstimo dos livros:

"Mais en ceux là (et il en est um nombre infiny de ce genre) qui establissent leur fondamentale suffisance et valeur, qui se raportent de leur entendement à leur memoire, $[\mathrm{C}]$ sub aliena umbra latentes, $[\mathrm{B}]$ et ne peuvent rien que par livre, je le hay, si je l'ose dire, un peu plus que la bestise."

[Mas àqueles (e há um número infinito deste gênero) que estabelecem sua fundamental suficiência e valor, que apoiam seu entendimento em sua memória [C] escondendo-se sob sombra alheia, [B] e não podem nada senão por livro, eu os odeio, se o ouso dizer, um pouco mais do que [odeio] a bestialidade.] (ibid.; citação latina de SEN. Ep. XXXIII)

Aflora aqui um tópos recorrente dos Ensaios, nesta oposição entre um "saber" que é puramente de memória, e um "saber" que resulta de uma verdadeira "assimilação" das lições contidas não só nos livros, como também tomadas da experiência. E é aí que se estabelece um novo critério que separe os homens segundo seu valor e mérito, já que não se pode contar mais com o conhecimento e a verdade, e todo jogo se passa no âmbito da "maneira". Mas como podemos falar em "saber" aqui, sendo que já vimos como Montaigne se inscreve na tradição do Ceticismo e nele assenta um traço fundamental da

${ }^{36}$ Cf. I, 26, p. 150. 
aptidão para a conversa? O sentido deste "saber", no entanto, é esclarecido se nos lembrarmos de um passo do "Da experiência" em que aparece o significado preciso da "ignorância" que se reserva, segundo o ensaísta, a toda uma tradição venerável da filosofia, ${ }^{37}$ incluindo evidentemente os céticos:

"Les difficultez et l'obscurité ne s'aperçoivent en chacune science que par ceux qui y ont entrée. Car encore faut il quelque degré d'intelligence à pouvoir remarquer qu'on ignore, et faut pousser à une porte pour sçavoir qu'elle nous est close."

[As dificuldades e a obscuridade não são percebidas em cada ciência senão por aqueles que nelas penetrou. Pois, ainda é preciso algum grau de inteligência para poder observar que se ignora, e é preciso empurrar uma porta para saber que ela para nós está fechada.] (III, 13, p.1075)

Esta percepção de que se ignora, por parte daqueles que penetraram com inteligência nas ciências, ou seja, por aqueles que fizeram o esforço de "empurrar uma porta" para descobrir que ela está fechada, não é à-toa que o encontramos associado a uma "ignorância" que em nada se aproxima da

\footnotetext{
${ }^{37} \mathrm{Na}$ Apologia Montaigne estende amplamente o alcance desta tradição; cf. II, 12, p. 511: "Je ne me persuade pas aysement qu'Epicurus, Platon et Pythagoras nous ayent donné pour argent contant leurs Atomes, leurs Idées et leurs Nombres. Ils estoient trop sages pour establir leurs articles de foy de chose si incertaine et si debatable." [Não me persuado facilmente que Epicuro, Platão e Pitágoras tenham dado por moeda corrente seus Átomos, suas Ideias e seus Números. Eles eram demasiado sábios para estabelecer seus artigos de fé em coisa tão incerta e tão discutível.]
} 
"indigestão" de que são acusados os sçavants. Ele é da mesma ordem que a "experiência" no sentido mais elevado que aflora em outro momento no "De l'art de conferer", em que o ensaísta contrasta duas "experiências": uma que é mero relato de ocorrências ou vivências particulares; e outra que nasce do exercício do entendimento e do julgamento sobre elas:

"Je leur dirois [no contexto, Montaigne dirige-se hipoteticamete a uma alta personagem, destacada por sua ciência ou por sua posição social] que le fruict de l'experience d'un chirurgien n'est pas l'histoire de ses practiques, et de se souvenir qu'il a guery quatre empestez et trois gouteux, s'il ne sçait de cet usage tirer dequoy former son jugement, et ne nous sçait faire sentir qu'il soit devenu plus sage à l'usage de son art. [...] Si les voyages et les charges les ont amendez, c'est à la production de leur entendement de le faire paroistre. Ce n'est pas assez de compter les experiences, il les faut poiser et assortir; et les faut avoir digerées et alambiquées, pour en tirer les raisons et conclusions qu'elles portent."

[Eu lhe diria de bom grado que o fruto da experiência de um cirurgião não é a história de suas práticas, e se recordar de que curou quatro empestados e três gotosos, se ele não souber tirar deste exercício o de que formar seu julgamento, e não nos souber fazer perceber que se tornou mais sábio com o exercício de sua arte. [...] Se as viagens e os cargos os têm emendado, é à produção de seu entendimento [que cabe] fazê-lo transparecer. Não basta contar as experiências, é preciso pesá-las e confrontá-las; e é preciso tê-las digerido e destilado, para extrair-Ihes as razões e conclusões que portam.] (III, 8, p.931) 
A experiência no sentido mais elevado a que aludimos acima se constitui, como vemos, a partir do trabalho ativo e inteligente do sujeito da experiência sobre cada uma de suas "experiências", trabalho que "pesa e compara", "digere e destila" as lições - de livros, da vida - que cada situação faz confrontar. As produções do entendimento mudam e fazem transparecer uma melhora e emenda, por meio deste trabalho de formação do discernimento e julgamento que leva em conta razões e conclusões de cada caso vivenciado. Vemos como este processo, ainda que não chegue a constituir ciência num sentido pleno para Montaigne, pois não avança no sentido de uma generalização abstrata que retém o semelhante de cada caso particular, não pode, igualmente, se deter na simples recordação (souvenir), principal defeito dos sçavants que se valem somente de um saber que não é deles, pois não foi devidamente assimilado, apropriado e modificado, uma vez que só reproduzem o que retiveram na memória. Assim, a atividade que forma o juízo e o entendimento, acentua e aguça a penetração inteligente nas articulações de um "saber" que permanece, por assim dizer, problemático, mas sobre o qual se produz, com o exercício, uma modificação profunda no homem, que mostra ter se tornado "mais sábio", ou, em termos estritamente montaignianos, homme suffisant, mesme à ignorer.

Assim, vemos como Montaigne faz conviver uma profunda cultura do espírito, ciente de seus modos de proceder e segura de seus passos, com o reconhecimento da precariedade de todo conhecimento humano. Diferentemente de um retrato mais contemporâneo do ensaísta, nossa leitura tenta fazer ver que ele está profundamente enraizado em seu tempo e nos 
modos de pensar de seu tempo, preservando, sim, uma altiva liberdade de opinião e conduta, mas que não é avessa aos modos dos seus contemporâneos, porque soube apropriar-se deles e fazê-los seus.

\section{A obra: a conformação do ensaio}

Com a análise que empreendemos da institution e das "performances" da suffisance montaigniana, procuramos mostrar o quanto se conformam às lides dos letrados do seu tempo. Logo, que não devemos avaliar a manière e seus protestos de liberdade sem levar em conta esse pertencimento. Resta apontar, em alguns passos fundamentais para a compreensão da "empresa" e da constituição do gênero ensaio, a presença de algumas tópicas ligadas à construção verossímil do retrato que corroborem o sentido do que estamos querendo advertir quanto a alguns pontos relevantes para uma interpretação, no nosso entender, mais adequada - porque preocupada com sua inscrição histórica e as práticas do tempo - dos Ensaios.

No centro de nossas preocupações está a questão da ordem e unidade do texto, em meio a aparente desordem que nele reina - ordem e unidade garantidas pelos desempenhos da teste bien faicte que se examinou. Nesse sentido, importa repassar, de saída, algumas das formulações conscientes e mais maduras de Montaigne quanto a sua empresa. São aquelas do tempo em que formula claramente o seu projeto de autorretrato. 
A obra montaigniana, como se sabe, atualiza de modo engenhoso a antiga tópica socrática do conhecimento de si, em seu projeto de estudo do homem, levado a efeito, sobretudo, pelo autorretrato. Desde o aviso Ao leitor que encabeça a obra, Montaigne define os contornos do que pretende:

“[A] C'est icy un livre de bonne foy, lecteur. II t'advertit dès l'entrée, que je ne m'y suis proposé aucune fin, que domestique et privée. Je n'y ay eu nulle consideration de ton service, ny de ma gloire. Mes forces ne sont pas capables d'un tel dessein. Je l'ay voué à la commodité particuliere de mes parens et amis: à ce que m'ayant perdu (ce qu'ils ont à faire bien tost) ils y puissent retrouver aucuns traits de mes conditions et humeurs, et que par ce moyen ils nourrissent plus entiere et plus vifve, la connoissance qu'ils ont eu de moy. Si c'eust esté pour rechercher la faveur du monde, je me fusse mieux paré et me presanterois en une marche estudiée. Je veus qu'on m'y voie en ma façon simple, naturelle et ordinaire, sans contention et artifice: car c'est moy que je peins. Mes defauts s'y liront au vif, et ma forme naïfve, autant que la reverence publique me l'a permis. Que si j'eusse esté entre ces nations qu'on dict vivre encore sous la douce liberté des premieres loix de nature, je t'asseure que je m'y fusse tres-volontiers peint tout entier, et tout nud. Ainsi, lecteur, je suis moy-mesmes la matiere de mon livre: ce n'est pas raison que tu employes ton loisir en un subject si frivole et si vain. A Dieu donq, de Montaigne, ce premier de Mars mille cinq cens quatre vingts."

[[A] Está aqui um livro de boa-fé, leitor. Desde o início ele te adverte que não me propus nenhum fim que não doméstico e privado. Nele não levei em consideração teu serviço, nem minha glória. Minhas forças não são capazes de um tal intento. Votei-o ao benefício particular de meus parentes e amigos; para 
que, ao me perderem (do que correm o risco dentro em breve), possam reencontrar nele alguns vestígios de minhas tendências e humores, e que por esse meio mantenham mais íntegro e mais vivo o conhecimento que tiveram de mim. Se fosse para buscar o favor do mundo, eu me paramentaria melhor e me apresentaria em uma postura estudada. Quero que me vejam aqui em minha maneira simples, natural e habitual, sem apuro e artifício: pois é a mim que pinto. Nele meus defeitos serão lidos ao vivo, e minha maneira natural, tanto quanto o respeito público mo permitiu. Pois, se eu tivesse estado entre aqueles povos que se diz viverem ainda sob a doce liberdade das primeiras leis da natureza, asseguro-te que de muito bom grado me teria pintado inteiro e nu. Assim, leitor, sou eu mesmo a matéria de meu livro: não é sensato que empregues teu lazer em um assunto tão frívolo e tão vão. A Deus pois, de Montaigne, neste primeiro de março de mil quinhentos e oitenta.] (Note au Lecteur, p. 3.)

Devemos reconhecer que este texto é, em grande medida, paradoxal. Nesse proêmio que deveria recomendar a obra ao público em geral por seu interesse e proveito, Montaigne nega, orgulhosa e altivamente, que presta um serviço e o restringe, ao ambiente familiar e privado, eximindo-se de qualquer ambição maior e despedindo o leitor que não pertence a esse círculo em sua primeira página. Desqualifica, ademais, o assunto, "frívolo e vão", indigno como ocupação dos lazeres desse anônimo leitor. Montaigne parece apor aqui um sinal negativo a tudo que se preceitua deva conter um proêmio. A captatio benevolentiae pede que se faça o ouvinte ou leitor, atento, dócil e benevolente, 
e que se o instrua sobre o que irá tratar. Montaigne não promete nem proveito, nem prazer, e, deixando claro o assunto, desqualifica-o dianto do leitor. Nada mais adequado, já se notou, para aguçar-lhe a curiosidade e cumprir o ofício de uma introdução. Além disso, em sua primeira linha esse texto já traz o termo fundamental que organiza o propósito central da obra: bonne foy. A "fé" aqui destacada faz convergirem muitos dos motivos que Montaigne enfeixa no livro, a fim de que seu retrato "natural" tenha como efeito a produção dessa confiança, dos quais podemos lembrar, rapidamente, a critica dos artifícios e da dissimulação maquiavélica, os protestos de liberdade e sinceridade da palavra (parresia), os ataques desfechados contra um dos mais odiosos vícios, que é a mentira, as confissões inumeráveis de falta de memória, entre outros.

Esse projeto assinalado por um cunho privado, com o que Montaigne garante para si a possibilidade de falar bastante livremente de muita matéria delicada no ambiente político e religioso do seu tempo, encontra pela frente um escolho difícil de contornar sem soçobrar: a proibição de falar de si. Pois, um intento dessa natureza sofre imediatamente a censura de ceder ao orgulho. Em um livro com o caráter privado assinalado a questão se complica. É preciso não só lutar contra a proibição de falar de si, como legitimar o projeto de exibir uma vida pouco proeminete nas ações. Montaigne manobra o leme de sua barca com perícia, dando ao livro esse caráter de retrato de um homem de condição média, instruído, obviamente, e que se pinta, com a pena, pensando e meditando sobre muita matéria moral, política e religiosa, num diálogo bastante denso com o passado, com que lida com grande desenvoltura, embora também com 
acentuada modéstia. Nesse exercício empenha a qualidade única que reconhece em si, que é o "senso", qualidade vulgar, pois pertencente a todos. Disso nos fala, num passo importante do capítulo "Da Presunção":

"[A] Somme, pour revenir à moy, ce seul par où je m'estime quelque chose, c'est ce en quoy jamais homme ne s'estima deffaillant: ma recommendation est vulgaire, commune et populaire, car qui a jamais cuidé avoir faute de sens?"

[[A] Em suma, para voltar a mim, a única coisa pela qual me valorizo um pouco é algo em que homem nunca se considerou falho: meu elogio é banal, comum e vulgar, pois quem jamais pensou ter falta de senso ?] (II, 17, p. 656.)

Combatendo uma possível acusação de presunção, Montaigne havia por muitas páginas negado a si todo tipo de qualidade, sobretudo as ligadas às produções do espírito ("effets de l'esprit”), para, enfim, isolar esta única, o "senso" ou capacidade de julgamento, a partir da qual constrói sua obra:

"[A] Nous reconnoissons ayséement és autres l'advantage du courage, de la force $[\mathrm{C}]$ corporelle, $[\mathrm{A}]$ de l'experience, de la disposition, de la beauté; mais l'advantage du jugement, nous ne le cedons à personne; et les raisons qui partent du simple discours naturel en autruy, il nous semble qu'il n'a tenu qu'à regarder de ce costé là, que nous les ayons trouvées. La science, le stile et telles parties que nous voyons és ouvrages estrangers, nous touchons bien aiséement si elle surpassent les nostres; mais les simples productions de l'entendement, chacun pense qu'il estoit en luy de les rencontrer toutes pareilles, 
et en apperçoit malaisement le poids et la difficulté, [C] si ce n'est, et à peine, en une extreme et incomparable distance. [A] Ainsi, c'est une sorte d'exercitation de laquelle je dois esperer fort peu de recommendation et de louange, et une maniere de composition de peu de nom."

[[A] Facilmente reconhecemos nos outros a superioridade da coragem, da força [C] física, [A] da experiência, da boa disposição, da beleza ; mas a superioridade do discernimento não cedemos a ninguém; e as razões que provêm do simples bom senso inato de outrem, parece-nos que só dependia de olharmos para aquele lado e as teríamos encontrado. O conhecimento, 0 estilo e outras qualidades que vemos nas obras alheias, nós as tocamos muito facilmente se superarem as nossas; mas as simples produções da inteligência, cada qual pensa que estava em si descobri-las iguais, e com dificuldade percebe-Ihes o peso e a dificuldade, [C] a não ser, e mal, se a distância for extrema e incomparável. [A] Assim, esse é um tipo de exercício do qual devo esperar pouca glória e louvor, e uma forma de composição de pouco renome.] (ibid., p. 656-7.)

Esse texto indica de modo suficientemente claro a matriz da invenção dos Ensaios, e também um germe de explicação de sua disposição, pois Montaigne pretende manter-se no campo das "simples produções do entendimento" e não espera extrair daí grande reconhecimento. Já vimos, que em "Dos Livros", Montaigne associa seus escritos ao exercício de suas "faculdades naturais". Mas o modo como opera o "senso" nos "exercícios do julgamento" que compõem cada ensaio ele o explicita no início do capítulo "De 
Demócrito e Heráclito", onde colhemos informações mais precisas sobre seus modos de atuação:

"[A] Le jugement est un util à tous subjects, et se mesle par tout. A cette cause, aux essais que j'en fay ici, j'y employe toute sorte d'occasion. Si c'est un subject que je n'entende point, à cela mesme je l'essaye, sondant le gué de bien loing; et puis, le trouvant trop profond pour ma taille, je me tiens à la rive: et cette reconnoissance de ne pouvoir passer outre, c'est un traict de son effect, voire de ceux dequoy il se vante le plus. Tantost, à un subject vain et de neant, j'essaye voir s'il trouvera dequoy lui donner corps, et dequoy l'appuyer et estançonner. Tantost je le promene à un subject noble et tracassé, auquel il n'a rien à trouver de soy, le chemin en estant si frayé qu'il ne peut marcher que sur la piste d'autruy. Là il fait son jeu à eslire la route qui luy semble la meilleure, et, de mille sentiers, il dict que cettuy-cy, ou celuy là, a esté le mieux choisi. Je prends de la fortune le premier argument. Ils me sont également bons. Et ne desseigne jamais de les produire entiers. [C] Car je ne voy le tout de rien: Ne font pas, ceux qui promettent de nous le faire veoir. De cent membres et visages qu'a chaque chose, j'en prens un tantost à lecher seulement, tantost à effleurer; et par fois à pincer jusqu'à l'os. J'y donne une poincte, non pas le plus largement, mais le plus profondement que je sçay. Et aime plus souvent à les saisir par quelque lustre inusité. Je me hazarderoy de traitter à fons quelque matière, si je me connoissoy moins. Semant icy un mot, icy un autre, eschantillons despris de leur piece, escartez, sans dessein et sans promesse, je ne suis pas tenu d'en faire bon, ny de m'y tenir moy mesme, sans varier quand il me plaist; et me rendre au doubte et incertitude, et à ma maistresse forme, qui est l'ignorance. Tout mouvement nous descouvre." 
[O julgamento é um instrumento para todos os assuntos, e se imiscui por toda parte. Por causa disso, nos ensaios que faço aqui, emprego nisso toda espécie de oportunidade. Se é um assunto de que nada entendo, por isso mesmo ensaio-o, sondando o vau de bem longe; e depois, achando-o fundo demais para minha estatura, mantenho-me na margem; e esse reconhecimento de não poder passar para o outro lado é uma característica de sua ação, e mesmo das que mais o envaidecem. Por vezes, em um assunto vão e sem valor, procuro ver se ele encontrará com que Ihe dar corpo, e com que o apoiar e escorar. Por vezes passeio-o por um assunto nobre e repisado, no qual nada tem a descobrir por si, estando o caminho tão trilhado que ele só pode caminhar sobre as pegadas de outrem. Então atua escolhendo o caminho que the parece o melhor e, entre mil veredas, diz que esta, ou aquela, foi a mais bem escolhida. Tomo da fortuna o primeiro argumento. Eles me são igualmente bons. Mas nunca me proponho apresentá-los inteiros. [C] Pois não vejo o todo de coisa alguma; tampouco o vêem os que nos prometem mostrá-lo. De cem membros e rostos que cada coisa tem, tomo um, ora para somente roçá-lo, ora para examinar-Ihe a superfície; e às vezes para pinçá-lo até o osso. Faço-Ihe um furo, não o mais largo porém o mais fundo que sei. E quase sempre gosto de captálos por algum ângulo inusitado. Arriscar-me-ia a tratar a fundo alguma matéria, se me conhecesse menos. Semeando aqui uma palavra, ali uma outra, retalhos tirados de sua peça, separados, sem intenção e sem compromisso, não estou obrigado a fazê-lo bem nem a limitar a mim mesmo, sem variar quando me aprouver; e render-me à dúvida e incerteza, e à minha forma principal, que é a ignorância. Todo e qualquer movimento nos revela.] (I, 50, p. 301-2) 
Em nenhum outro lugar Montaigne afirma de maneira tão enfática que sua obra resulta dessa aplicação do julgamento nas mais diversas ocasiões. Aqui ele se esforça em distinguir os vários "assuntos" (subject) possíveis e marca de forma inequívoca sua atitude. É a invenção dos Ensaios que está em causa. Primeiro, é de notar que a suffisance labora em assuntos que pode ignorar totalmente. Como nota no mesmo "Da Presunção" que acabamos de lembrar, "je sçay bien soustenir une opinion, mais non pas la choisir" (II, 17, p. 654). As marcas do ceticismo são amplamente espalhadas pelo livro. Igualmente nesse passo em que reconhece orgulhosamente sua capacidade de manter-se na margem, quando não consegue atravessar. O que nos interessa mais, porém, é essa capacidade de sustentar opiniões. Montaigne afirma que passeia seu julgamento por matérias vãs ou nobres. Num caso, busca com que lhe dar sustentação. No outro, opera escolhendo, das sendas batidas pela tradição, qual delas julga melhor. Não poderia ser mais direto na indicação de que há discursos, sobretudo os dos antigos, dos quais não quer se destacar. Se não julga a "verdade" deles, já que a atitude cética o impede, julga muito bem sua pertinência e valor. $E$, além disso, constrói frequentemente seu discurso nas trilhas do pensamento antigo. O que se explicita aqui, portanto, é uma capacidade "eletiva" na produção do discurso que opera a partir dos discursos alheios. O ensaio, no entanto, tem outros traços que ficam assinalados aqui. Eles partem casualmente de qualquer ponto (argument), sendo indiferente 0 assunto de que vai tratar. E também não tratam um assunto por inteiro. Como o tratamento das matérias é antes ocasião para o exercício do julgamento, 
portanto, para pôr em funcionamento essa faculdade, o seu tratamento dispensa a totalidade e pode variar à vontade. Dispensa também conquistar a verdade acerca dessas mesmas matérias. O que importa é a pertinência do andamento desse exercício, como nos ensina, vimos, o "Da Arte da Conversação" que concebia os Ensaios como uma busca ("caça") sem termo, própria à nossa condição falível e à impossibilidade para nós de alcançar a "verdade":

"[B] L'agitation et la chasse est proprement de nostre gibier: nous ne sommes pas excusables de la conduire mal et impertinemment; de faillir à la prise, c'est autre chose. Car nous sommes nais à quester la verité; il appartient de la posseder à une plus grande puissance. [...] [C] Le monde n'est qu'une escole d'inquisition."

[ $A$ agitação e a caçada são propriamente de nossa alçada; não temos desculpa por conduzi-la mal e tolamente; falhar na captura é outra coisa. Pois nascemos para buscar a verdade, possuí-la pertence a uma potência maior. [...] O mundo não é mais que uma escola de inquisição.] (III, 8, p. 928)

Sabemos que a "pertinência" alegada aqui garante a graça dos escritos de Montaigne ('C'est n'est pas a qui mettra dedans, mais à qui fera les plus belles courses" - ibid.). Mas o nexo que preside as sequências dos arrazoados, o nexo do "à propos", garante a sua unidade? Para responder é preciso retomar duas tópicas que Montaigne aplica ao falar de seus escritos e que parecem the roubar a coerência de um discurso ordenado, condenando-o a 
uma errância sem termo e, o que é mais grave, sem consequência. Lembremos, primeiramente, a imagem presente no "Da Ociosidade":

“[A] Dernierement que je me retiray chez moy, deliberé autant que je pourroy, ne me mesler d'autre chose que de passer en repos, et à part, ce peu qui me reste de vie: il me sembloit ne pouvoir faire plus grande faveur à mon esprit, que de le laisser en pleine oysiveté, s'entretenir soy mesmes, et s'arrester et rasseoir en soy: ce que j'esperois qu'il peut meshuy faire plus aisément, devenu avec le temps plus poisant, et plus meur. Mais je trouve,

variam semper dant otia mentem,

que au rebours, faisant le cheval eschappé, il se donne cent fois plus d'affaire à soy mesmes, qu'il n'en prenoit pour autruy; et m'enfante tant de chimeres et monstres fantasques les uns sur les autres, sans ordre, et sans propos, que pour en contempler à mon aise l'ineptie et l'estrangeté, j'ay commancé de les mettre en rolle, esperant avec le temps luy en faire honte à luy mesmes."

[[A] Recentemente, ao isolar-me em minha casa, decidido, tanto quanto pudesse, a não me imiscuir em outra coisa que não seja passar em descanso e apartado esse pouco que me resta de vida, parecia-me não poder fazer maior favor a meu espírito do que deixá-lo, em plena ociosidade, entreter a si mesmo, fixar-se e repousar em si ; e esperava que doravante ele o pudesse fazer mais facilmente, tendo se tornado, com o tempo, mais ponderado e mais maduro. Porém descubro,

variam semper dant otia mentem, 
que ao contrário, imitando o cavalo fugido, ele dá a si mesmo cem vezes mais trabalhos do que assumia por outrem; e engendra-me tantas quimeras e monstros fantásticos, uns sobre os outros, sem ordem e sem propósito, que para examinar com vagar sua inépcia e estranheza comecei a registrá-los por escrito, esperando com o tempo fazer que se envergonhe de si mesmo por causa deles.] $(I, 8,32-3)$

Já se pensou, vimos, o ensaio como o "registro" escrito das "fantasias" de seu autor. Isso se faz em conformidade estrita com a letra dos Ensaios, que em passos como o acima citado, associa a origem do projeto de escrever com um registro de produções fantasiosas do espírito ocioso. A essa imagem, prende-se outra, do capítulo "Da Amizade", que insiste igualmente numa "desordem" dos escritos:

“[A] Considérant la conduite de la besongne d'un peintre que j'ay, il m'a pris envie de l'ensuivre. II choisit le plus bel endroit et milieu de chaque paroy, pour y loger un tableau élabouré de toute sa suffisance; et, le vuide tout au tour, il le remplit de crotesques, qui sont peintures fantasques, n'ayant grace qu'en la varieté et estrangeté. Que sont-ce icy aussi, à la verité, que crotesques et corps monstrueux, rappiecez de divers membres, sans certaine figure, n'ayants ordre, suite ny proportion que fortuite?

Desinit in piscem mulier formosa superne. 
Je vay bien jusques à ce second point avec mon peintre, mais je demeure court en l'autre et meilleure partie: car ma suffisance ne va pas si avant que d'oser entreprendre un tableau riche, poly et formé selon l'art."

[[A] Examinando o procedimento de um pintor num trabalho que possuo, senti vontade de imitá-lo. Ele escolheu o lugar mais belo e no centro de cada parede para ali instalar um quadro elaborado com todo o seu talento ; e o vazio ao redor, encheu-o de grutescos, que são pinturas fantasiosas cuja única graça está na variedade e estranheza. O que são estes também, na verdade, senão grutescos e corpos monstruosos, remendados com membros diversos, sem forma determinada, não tendo ordem, nexo nem proporção além da casualidade?

Desinit in piscem mulier formosa superne.

Acompanho bem meu pintor até esse segundo ponto, mas fracasso na outra e melhor parte; pois meu talento não vai tão longe a ponto de ousar tentar um quadro rico, polido e formado de acordo com a arte.] (I, 28, p. 183.)

Essa é a famosa página em que Montaigne associa seu livro aos "grotescos" que se proliferariam em torno do Discurso da Servidão Voluntária do amigo, Etienne de La Boétie. Mais uma vez mobilizando uma boa dose de modéstia, o Ensaísta associa a conformação dos seus escritos a falta de unidade. Obviamente, não se deve negar simplesmente a verdade dessas explicitações de intenção que Montaigne semeia no livro, mas advertir para o fato de que todas estão permeadas de grande ironia e modéstia que tendem comumente a 
rebaixar a obra, acusando neles uma falta de nexo coerente entre as partes. Naquele passo citado anteriormente, em que fala do "cavalo escapado", contudo, é notável como se separa dessas produções espontâneas e descontroladas uma instância que julga essas "quimeras e monstros fantásticos" e decide proceder ao registro na esperança de infundir vergonha nele mesmo. Essa distância mostra que as produções desregradas não assumem o controle, mas são observadas por uma razão indiferente que, de certa forma, as desqualifica. A aplicação de tais tópicas, ademais, entra como elemento bastante conveniente no propósito geral de pintar o homem ao "natural", um homem de condição média, cujo "progresso dos humores e opiniões" vai sendo representado de maneira verossímil no livro. Convém ainda notar a conveniência delas, num livro em que Montaigne, a par do problema da presunção lembrado acima, se representa pensando, e dá ao seu livro o andamento de uma conversa, que deve parecer regida pelo acaso das associações.

Montaigne associa essa característica de seus escritos expressamente a um desarranjo e negligência intencionais, como traço que convém ao fidalgo que não quer confundir-se com um faiseur de livres:

"[B] J'ay volontiers imité cette debauche qui se voit en nostre jeunesse, au port de leurs vetemens : un manteau en escharpe, la cape sur une espaule, un bas mal tendu, qui represente une fierté desdaigneuse de ces paremens estrangers, et nonchalante de l'art. Mais je la trouve encore mieus employée en la forme de parler. [C] Toute affectation, nommeement en la gayeté et liberté françoise, est mesadvenante au cortisan. Et, en une monarchie, tout 
Gentil' homme doit estre dressé à la façon d'un cortisan. Parquoy nous faisons bien de gauchir un peu sur le naïf et mesprisant."

[[B] De bom grado venho imitando esse descaso que se vê em nossa juventude, no porte de suas vestimentas : o manto de banda, o capote em um ombro, uma meia mal esticada, o que manifesta uma altivez desdenhosa desses ornamentos estrangeiros e despreocupada de artifícios. Mas acho-a ainda mais bem empregada na forma do falar. [C] Toda afetação, sobretudo na jovialidade e liberdade francesas, cai mal para o cortesão. E numa monarquia todo fidalgo deve ser educado à maneira de um cortesão. Por isso fazemos bem em desviarnos um pouco para o natural e o despretensioso.] (I, 26, "Da Educação das crianças", p. 172.)

Difícil não reconhecer o eco das discussões do "Cortesão" de Castiglione nesse passo. O que Montaigne expressa aqui, associando-o à produção do "natural", não é a ideia de uma negação com os ensinamentos e preceitos das artes, mas tão simplesmente o domínio deles e a arte da dissimulação da própria arte. A ideia, que aplica a sua própria obra, de que as partes devem carecer de costuras expressas, pois as partes mostram a pertinência de sua sucessão apenas pelo sentido, é tomada às lições de Horácio e são lembradas um pouco antes do texto acima citado (cf. ibid., p. 170-1). E trazidas também num momento decisivo do capítulo "Da Vaidade", no curso de uma digressão sobre matéria poética, que demonstra um conhecimento refinado das discussões: 
“[B] Cette farcisseure est un peu hors de mon theme. Je m'esgare, mais plustot par licence que par mesgarde. Mes fantasies se suyvent, mais par fois c'est de loing, et se regardent, mais d'une veuë oblique."

[Este recheio está um pouco fora de meu tema. Extravio-me, porém mais por permissividade do que por descuido. Minhas fantasias seguem uma às outras, mas às vezes de longe, e olham-se, mas com um olhar oblíquo.] (III, 9, p. 994.)

Nessas linhas Montaigne tece um longo elogio da "variação" nos escritos. É interessante nos estendermos um pouco na contextualização desse passo, pois as considerações de ordem "técnica" que Montaigne inscreve na sequência são aplicadas no próprio texto que acaba de produzir. Muito oportunamente ele as insere como quem se dá conta de uma anterior digressão a que se havia entregado sobre "a virtude reservada para os assuntos do mundo". É a ela que aponta com a expressão "cette farcisseure" ("recheio"). O contexto da primeira digressão, no capítulo, é o da resposta que dirige a objeções que a filosofia lança a ele contrárias ao seu gosto pelas viagens, que discute no capítulo. A filosofia o acusa de vaidade. A resposta dada discute, contra-atacando, a vaidade dos preceitos da filosofia para a vida do homem, tão elevados que ninguém os cumpre. $\mathrm{O}$ homem, em suma, imporia leis a si mesmo que ele transgride, porque é impossível cumpri-las. Isso dá ensejo a uma digressão primeira sobre as regras da vida pública, em que a virtude de um Catão é "fora de propósito". O ofício daquele que frequenta o mundo é criteriosamente separado daquele do homem que prefere a "liberdade e ociosidade" da vida 
reservada e privada. $O$ nexo que liga essas considerações sobre as conveniências públicas, distinguindo-as das privadas, à resposta que vinha articulando contra as objeções da filosofia por seu gosto pelas viagens é dado pela ideia de que há falta de "proporção entre o comando e a obediência". Por um lado, Montaigne, antes da digressão, criticava esses "objetivos que não se podem atingir". Isso, por outro, o leva a digressão acerca do desacordo entre as suas regras e as regras do mundo. Se lembrarmos que uma das razões alegadas por Montaigne para a viagem, colocada desde o início do capítulo, era o atual estado da França e suas divisões e guerras, nos damos conta do quão amarradas e pertinentes são essas digressões. Ao sábio, de corte estoico, que Ihe objetava vaidade ele opunha a consideração de que seus preceitos são irrealizáveis e, portanto, vãos. Porque, repitamos, há uma impossibilidade de obedecer ao que comandam. Ao mundo de que Montaigne foge viajando, outra desproporção ele opõe: a dos seus costumes, "noções e regras de viver", e os impostos pelas ocupações com o mundo, mormente o mundo corrompido do seu século e país. Isso, por fim, sem lamentar e sem desejar que o mundo das relações entre os homens seja diverso e que seja razoável mesmo o seu desacordo.

Essa breve consideração sobre a oportunidade dos desvios e digressões que antecedem as considerações propriamente "poéticas" servem de advertência e exemplo para o domínio preciso com que Montaigne cose ao eixo de seu arrazoado essas "escapadas". Entre as duas, a escolha precisa de uma citação de Vergílio (Quo diversus abis? "para onde te extravias?") deixa ainda 
mais patente a consciência com que produz a variação e salta de uma a outra. Seguem o elogio do Fedro de Platão, que desafia os leitores que tentam harmonizar os temas do amor e da retórica nos quais ele se divide. Também lembra Plutarco, que no "Demônio de Sócrates" "esquece o seu tema" e o “assunto não é encontrado senão incidentalmente". E entusiasmado, acrescenta, desafiando o "indiligente leitor":

"[C] O Dieu, que ces gaillardes escapades, que cette variation a de beauté, et plus lors que plus elle retire au nonchalant et fortuite. C'est l'indiligent lecteur qui pert mon subject, non pas moy; ils s'en trouvera tousjours en un coing quelque mot qui ne laisse pas d'estre bastant, quoy qu'il soit serré. [B] Je vois au change, indiscrettement et tumultuairement. [C] Mon stile et mon esprit vont vagabondant de mesmes. [B] II faut avoir un peu de folie qui ne veut avoir plus de sottise, [C] disent et les preceptes de nos maistres et encores plus leurs exemples. "

[Oh, Deus, como essas galhardas escapadelas, como essa variação tem beleza, e tanto mais quanto mais parecer descuidosa e casual ! É o leitor indiligente que perde meu assunto, não sou eu ; sempre se encontrará num cantinho alguma palavra que não deixe de ser suficiente, embora seja concisa. [B] Vou em busca da variedade, de forma desmedida e tumultuosa. [C] Meu estilo e meu espírito vão vagabundeando ambos. [B] Precisa ter um pouco de loucura quem não quiser ter mais de tolice, [C] dizem os preceitos de nossos mestres e mais ainda seus exemplos.] (ibid., p. 994-5.)

O termo "indiligente", empregado aqui para qualificar o leitor, não deixa dúvida que Montaigne tem em mente que a variação é produto de um trabalho 
intencional, "diligente", que produz a variação como efeito calculado e não um resultado do mero acaso, a despeito das múltiplas afirmações nesse sentido, aliás, elementos constantes da mesma tópica da "negligência diligente", que nega o emprego de artifício e premeditação. Difícil não reconhecer, portanto, que se trata de uma "licença" autorizada e preceituada pelos mestres, e mesmo praticada por eles.

É claro que Montaigne acentua o aspecto de desordem do texto em conformidade com a inconstância que busca mostrar como característica "constante" do homem. Nesse sentido a variação a que ele se entrega ganha ainda um maior interesse, pois convém a técnica aplicada perfeitamente ao propósito de retratar essas oscilações. É um senso de conveniência, prépon, que, ao dar a conformação aos escritos de um discurso regido pelo acaso, ganha expressão pela mão do Ensaísta, que pode afirmar que suas fantasias são conduzidas pela sorte, não pela arte, e ao mesmo tempo lembrar o motivo central das lições de retórica que sustentam o primado do trabalho das res, ou das "concepções", sobre as verba, ou da "disposição e elocução" do seu discurso:

"Aumoins, j'ay cecy selon la discipline, que jamais homme ne traicta subject qu'il entendit ne cogneust mieux que je fay celuy que j'ay entrepris, et qu'en celuy-là je suis le plus sçavant homme qui vive; secondement, que jamais aucun [C] ne penetra en sa matiere plus avant, ny en esplucha plus particulierement les membres et suites; et $[B]$ n'arriva plus exactement et plainement à la fin qu'il s'estoit proposé à sa besoingne." 
[Pelo menos tenho isto de acordo com a disciplina: que nunca homem nenhum tratou assunto que compreendesse ou conhecesse melhor do que trato este que empreendi, e nesse sou o homem mais sábio que vive; em segundo lugar, que nunca alguém [C] se aprofundou tanto em sua matéria nem esmiuçou-Ihe mais detalhadamente as partes e decorrências; e [B] nem chegou mais exata e plenamente ao fim que se propusera em sua tarefa.] (III, 2, "Do Arrependimento", p. 805.) 


\section{CONSIDERAÇõEs FinaIS}

Não iremos aqui fazer mais do que salientar alguns traços que procuramos, de algum modo, repassar na análise dos textos. Insistiu-se e insiste-se ainda que Montaigne figura como um escritor em ruptura com as lides do seu tempo. Esse trabalho procurou matizar essa leitura advertindo para uma série de tópicas presentes nas páginas dos Ensaios que remetem antes ao passado, à relação com as autoridades e com os modelos e preceitos, do que a um futuro que redefinirá as artes com um senso de autonomia muito distante de como foram pensadas antes.

Dizer que Montaigne, em seu projeto de autorretrato, procura inscrever e ostentar um éthos confiável nas páginas de seu livro, já é de algum modo se compromenter com a técnica ou arte que se empenha para produzir esse efeito. E com uma postura e método que toma os textos numa perspectiva "pragmática", deixando de lado as preocupações com a "verdade" biográfica do retrato, e atentando para a "verossimilhança" que constrói. O ensaio é, sim, o produto de uma capacidade, ao mesmo tempo instruída e exercitada, ou seja, é o resultado, consignado pela escrita, da atividade de pensamento de um "homme suffisant", de uma "teste bien faicte". E, apesar de toda licença que reina nas páginas do livro que intenta propor-nos um retrato ao natural, nosso esforço de leitura tentou mostrar que a "desenvoltura" que nelas se vê não deve ser fruto de uma autonomia radical do pensamento e de uma libertação dos modelos exemplares e regras preceituadas. O que ali ganha voz, ao contrário, é um desempenho hábil, uma perícia em lidar com elas, em operar adequações e 
conveniências, que definem os traços - para brincar com a fórmula tradicional atribuída a Catão - de um vir bonus iudicandi peritus.

Nesse sentido, tentamos recolocar, em primeiro lugar, esse homem no quadro de suas concepções sobre a educação da capacidade ("suffisance") e de dois dos seus principais exercícios: a leitura e a conversa, delineando assim características do "artífice" do ensaio. Depois, esboçadas essas características, procuramos repassar um núcleo de discussões retórico-poéticas que dão o contorno e a dimensão do diálogo estabelecido por Montaigne com lições dessa natureza, e segundo as quais, devemos pensar o gênero que se inventa e efetua nessas páginas.

Posta a coisa assim, parece que no fundo, quando falamos do ensaio, encontramos em sua origem uma disposição (héxis) - que poderíamos aproximar do sentido aristotélico da palavra - mais do que de uma ciência ou saber. Trata-se de uma disposição estável, porque instruída e exercitada na lide com as letras e na experiência do mundo, que está na origem dos ensaios e os forja como seus produtos. Uma capacidade prática pertencente ao domínio do fazer, para não dizer mesmo poética; um saber fazer talvez, mais do que um saber de ordem puramente contemplativa. Mas, não se trata de avançar numa distinção bem clara do fazer em práxis e poíesis. Pois, o ensaio, em virtude de seu horizonte e domínio prático, mescla o que é da ordem da ação com o que é da ordem da produção, na medida em que Montaigne não quer ser confundido com os simples faiseurs de livres. E também não se pode descartar tão 
facilmente a atitude do homem voltada para o saber, se não de ordem especulativa e contemplativa, ao menos da ordem da observação curiosa da diversidade do mundo, dos costumes humanos e da variação experimentada em si mesmo, saber todo ele orientado, não para o governo das coisas exteriores, assaltadas constantemente pelo acaso imprevisível para a prudência humana, mas para o governo de si mesmo, que se resolve na interioridade. Porque é também de um domínio, por assim dizer, intelectual, embora muito imediatamente implicado na prática humana e sua orientação, de que falamos, quando tentamos caracterizar os múltiplos exercícios do Ensaísta. Porque é também da ordem da inteligibilidade, do discernimento, do uso e exercício do julgamento, a produção escrita montaigniana, guiada por um senso, mais do que por uma ciência, um senso apoiado, por uma parte, nas lições negativas da razão cética e na experiência, por outra, no conhecimento profundo das letras e na lide engenhosa com seus modos.

O ensaio exclui, por um lado, o pretenso saber e a inadequação dos sçavants ("sábios competentes") que em sua servilidade ao preceito e "opiniastreté" incorrem na tolice e "má afetação". Por outro, é preciso reconhecer que Montaigne não se investe dos traços mais elevados das produções intelectuais, nem das ações morais, que reconhece nos antigos. A entrega à "variação" e a sprezzatura de seu retrato normalmente são associadas por ele a esse traço de inconstância, que nota universalmente no homem, no caso de suas produções, inconstância. Mas é aí mesmo que flagramos sua maior adequação e a aplicação mais decorosa das lições que assimila da tradição. Ao 
se denegar a perfeição dos antigos, ao recusar em termos morais, intelectuais e artísticos as qualidades que tão argutamente é capaz de julgar presente neles, é que nos revela sua verdadeira capacidade e senso. Põe-se de acordo com essa natureza lábil, móvel, que se deleita na "vanidade", e procura dar um corpo a ela e valorizá-la. Podemos, então, observar que a disposição prática montaigniana, que está na origem de seus exercícios do julgamento, é concernente às regras da escolha. O senso é capaz, nos casos todos singularíssimos, de ditar o que convém e o que não convém, o que é ou não adequado fazer ou dizer, o que é, em suma, oportuno fazer ou dizer em cada caso. Ele é capaz de iluminar as regras que presidem as escolhas, ainda que não seja sempre capaz das mesmas escolhas e ações, isto é, das ações conformes a essas regras.

Os exercícios do julgamento de que se compõem os capítulos do livro de Montaigne, em suma, têm como horizonte e escopo a orientação moral, mas que esta passa pelas dificuldades tanto objetivas como subjetivas desse exercício. O pensamento montaigniano nunca deixa de ser uma busca, nunca conquista verdades definitivas. Logo, sua principal conquista é, por um lado, mais a desestabilização das certezas que uma aquisição crescente de normas e regras seguras que balizem a ação. Mas, por outro lado, se o que vale nesse exercício não está no plano das certezas conquistadas, nem na aplicabilidade de regras aprendidas e aplicadas, está certamente na segurança e força da capacidade mesma de se exercer nas diversas ocasiões que se apresentam. Seus resultados contam menos do que seus desempenhos, do que a segurança dos seus passos. Pois, qual o fim dos movimentos de pensamento que 
observamos nos capítulos d'Os Ensaios? Não se trata certamente de obter, no fim de um percurso, um conhecimento acerca da matéria escolhida e examinada. Trata-se, mais propriamente, de uma exibição da própria capacidade de examinar apropriadamente uma questão. A maneira é isso: exibição de capacidade, suffisance em ato. É certo que não há uma total indiferença pelo que se vai explanando nesse percurso. A capacidade é capacidade de escolher de maneira adequada as matérias, os argumentos, as figuras. O caminho, e seus passos, são apropositados quanto à matéria e à palavra que a explicita. Existe adequação, decoro, conformidade. É nesse sentido que podemos pensar na presença de uma arte nos Ensaios. 


\section{ANEXO}

Acreditamos ser bastante útil para o leitor poder ter sob os olhos um inventário, não exaustivo, das passagens dos Ensaios (textos reflexivos, quase todos, sobre a própria lide do Ensaísta com sua obra), cuja frequentação - assídua nos sugeriu a interpretação que neste trabalho apresentamos. Assim, as transcrevemos em seguida, segundo a sequência dos livros e capítulos em que aparecem. Acreditamos que, aproximadas, possam catalizar elementos de convicção sobre as questões que abordamos, diversos daqueles proporcionados por sua leitura segmentada ao longo do percurso de palmilhamento de toda a obra montaigniana, onde, dispersas entre os outros temas e motivos, elas tendem a ser obscurecidas.

Trata-se, quanto a boa parte destas passagens, de digressões que escapam ao fio principal dos "essais de jugement" em que estão inscritas, de modo que nos pareceu possível recortá-las sem proceder às contextualizações necessárias, na maioria dos temas, em Montaigne - isso porque as concepções nesse campo da escrita, diferentemente de outros temas, nos parecem de uma constância que atravessa a obra em suas camadas sem mudança sensível. 


\section{Livro I}

\section{(I, 1, “Au Lecteur”, p. 7.)}

C'est icy un livre de bonne foy, lecteur. II t'advertit dès l'entrée, que je ne m'y suis proposé aucune fin, que domestique et privée. Je n'y ay eu nulle consideration de ton service, ny de ma gloire. Mes forces ne sont pas capables d'un tel dessein. Je l'ay voué à la commodité particuliere de mes parens et amis: à ce que m'ayant perdu (ce qu'ils ont à faire bien tost) ils y puissent retrouver aucuns traits de mes conditions et humeurs, et que par ce moyen ils nourrissent plus entiere et plus vifve, la connoissance qu'ils ont eu de moy. Si c'eust esté pour rechercher la faveur du monde, je me fusse mieux paré et me presanterois en une marche estudiée. Je veus qu'on m'y voie en ma façon simple, naturelle et ordinaire, sans contention et artifice: car c'est moy que je peins. Mes defauts s'y liront au vif, et ma forme naïfve, autant que la reverence publique me l'a permis. Que si j'eusse esté entre ces nations qu'on dict vivre encore sous la douce liberté des premieres loix de nature, je t'asseure que je m'y fusse tres-volontiers peint tout entier, et tout nud. Ainsi, lecteur, je suis moy-mesmes la matiere de mon livre: ce n'est pas raison que tu employes ton loisir en un subject si frivole et si vain. A Dieu donq, de Montaigne, ce premier de Mars mille cinq cens quatre vingts.

\section{(I, 3, “Nos Affections S'emportent au dela de Nous”, p. 16.)}

Ce grand precepte est souvent allegué en Platon: Fay ton faict et te cognoy. Chascun de ces membres enveloppe generallement tout nostre devoir, et semblablement enveloppe son compagnon. Qui auroit à faire son faict, verroit que sa premiere leçon, c'est cognoistre ce qu'il est et ce qui luy est propre. Et qui se cognoist, ne prend plus l'estranger faict pour le sien: s'ayme et se cultive avant toute autre chose: refuse les occupations superflues et les pensées et propositions inutiles.

\section{(I, 1, “De l'Oisiveté”, p. 32-3.)}

Comme nous voyons des terres oysives, si elles sont grasses et fertilles, foisonner en cent mille sortes d'herbes sauvages et inutiles, et que, pour les tenir en office, il les faut assubjectir et employer à certaines semences, pour nostre service; et comme nous voyons que les femmes produisent bien toutes seules, des amas et pieces de chair informes, mais que pour faire une generation bonne et naturelle, il les faut embesoigner d'une autre semence: ainsin est-il des espris. Si on ne les occupe à certain sujet, qui les bride et contreigne, ils se jettent desreiglez, par-cy par là, dans le vague champ des imaginations,

Sicut aquae tremulum labris ubi lumen ahenis

Sole repercussum, aut radiantis imagine Lunae

Omnia pervolitat latè loca, jamque sub auras

Erigitur, summique ferit laquearia tecti.

Et n'est folie ny réverie, qu'ils ne produisent en cette agitation, 
L'ame qui n'a point de but estably, elle se perd: car, comme on dict, c'est n'estre en aucun lieu, que d'estre par tout.

\section{Quisquis ubique habitat, Maxime, nusquam habitat.}

Dernierement que je me retiray chez moy, deliberé autant que je pourroy, ne me mesler d'autre chose que de passer en repos, et à part, ce peu qui me reste de vie: il me sembloit ne pouvoir faire plus grande faveur à mon esprit, que de le laisser en pleine oysiveté, s'entretenir soy mesmes, et s'arrester et rasseoir en soy: ce que j'esperois qu'il peut meshuy faire plus aisément, devenu avec le temps plus poisant, et plus meur. Mais je trouve,

variam semper dant otia mentem,

que au rebours, faisant le cheval eschappé, il se donne cent fois plus d'affaire à soy mesmes, qu'il n'en prenoit pour autruy; et m'enfante tant de chimeres et monstres fantasques les uns sur les autres, sans ordre, et sans propos, que pour en contempler à mon aise l'ineptie et l'estrangeté, j'ay commancé de les mettre en rolle, esperant avec le temps luy en faire honte à luy mesmes.

\section{(I, 9, “Des Menteurs”, p. 34-38.)}

II n'est homme à qui il siese si mal de se mesler de parler de memoire. Car je n'en reconnoy quasi trasse en moy, et ne pense qu'il y en aye au monde une autre si monstrueuse en defaillance. J'ay toutes mes autres parties viles et communes. Mais en cette-là je pense estre singulier et tres-rare, et digne de gaigner par là nom et reputation. Outre l'inconvenient naturel que j'en souffre-- car certes veu sa nécessité, Platon a raison de la nommer une grande et puissante deesse-- si en mon païs on veut dire qu'un homme n'a poinct de sens, ils disent qu'il n'a point de memoire, et quand je me plains du defaut de la mienne, ils me reprennent et mescroient, comme si je m'accusois d'estre insensé. Ils ne voyent pas de chois entre memoire et entendement. C'est bien empirer mon marché. Mais ils me font tort, car il se voit par experience plustost au rebours, que les memoires excellentes se joignent volontiers aux jugemens debiles. Ils me font tort aussi en cecy, qui ne sçay rien si bien faire qu'estre amy, que les mesmes paroles qui accusent ma maladie, representent l'ingratitude. On se prend de mon affection à ma memoire; et d'un defaut naturel, on en faict un defaut de conscience. II a oublié, dict-on, cette priere ou cette promesse. II ne se souvient point de ses amys. II ne s'est point souvenu de dire, ou faire, ou taire cela, pour l'amour de moy. Certes je puis aiséement oublier, mais de mettre à nonchalloir la charge que mon amy m'a donnée, je ne le fay pas. Qu'on se contente de ma misere, sans en faire une espece de malice, et de la malice autant ennemye de mon humeur. Je me console aucunement. Premierement sur ce que c'est un mal duquel principallement j'ay tiré la raison de corriger un mal pire qui se fust facilement produit en moy, sçavoir est l'ambition, car c'est une deffaillance insupportable à qui s'empesche des negotiations du monde; que, comme disent plusieurs pareils exemples du progres de nature, elle a volontiers fortifié d'autres facultés en moy, à mesure que cette-cy s'est affoiblie, et irois facilement couchant et allanguissant mon esprit et mon jugement sur les traces d'autruy, comme faict le monde, sans exercer leurs propres forces, si les inventions et opinions estrangieres m'estoient presentes par le benefice de la memoire; que mon parler en est plus court, car le magasin de la memoire est volontiers plus fourny de matiere que n'est celuy de 
l'invention: si elle m'eust tenu bon, j'eusse assourdi tous mes amys de babil: les subjects esveillans cette telle quelle faculté que j'ay de les manier et emploier, eschauffant et attirant mes discours. C'est pitié. Je l'essaye par la preuve d'aucuns de mes privez amys: à mesure que la memoire leur fournit la chose entiere et presente, ils reculent si arriere leur narration, et la chargent de vaines circonstances, que si le conte est bon, ils en estouffent la bonté; s'il ne l'est pas, vous estes à maudire ou l'heur de leur memoire, ou le malheur de leur jugement. Et c'est chose difficile de fermer un propos et de le coupper despuis qu'on est arroutté. Et n'est rien où la force d'un cheval se cognoisse plus qu'à faire un arrest rond et net. Entre les pertinents mesmes j'en voy qui veulent et ne se peuvent deffaire de leur course. Ce pendant qu'ils cerchent le point de clorre le pas, ils s'en vont balivernant et trainant comme des hommes qui deffaillent de foiblesse. Sur tout les vieillards sont dangereux à qui la souvenance des choses passées demeure, et ont perdu la souvenance de leurs redites. j'ay veu des recits bien plaisants devenir tres-ennuyeux en la bouche d'un seigneur: chascun de l'assistance en ayant esté abbreuvé cent fois. Secondement, qu'il me souvient moins des offenses receues, ainsi que disoit cet ancien; il me faudroit un protocolle, comme Darius, pour n'oublier l'offence qu'il avoit receu des Atheniens, faisoit qu'un page à tous les coups qu'il se mettoit à table, luy vinst rechanter par trois fois à l'oreille: Sire, souvienne vous des Atheniens: et que les lieux et les livres que je revoy me rient tousjours d'une fresche nouvelleté. Ce n'est pas sans raison qu'on dit que qui ne se sent point assez ferme de memoire, ne se doit pas mesler d'estre menteur. Je sçay bien que les grammairiens font difference entre dire mensonge, et mentir: et disent, que dire mensonge, c'est dire chose fauce, mais qu'on a pris pour vraye, et que la definition du mot de mentir en Latin, d'où nostre François est party, porte autant comme aller contre sa conscience, et que par consequent cela ne touche que ceux qui disent contre ce qu'ils sçavent, desquels je parle. Or ceux cy, ou ils inventent marc et tout, ou ils déguisent et alterent un fons veritable. Lors qu'ils déguisent et changent, à les remettre souvent en ce mesme conte, il est malaisé qu'ils ne se desferrent, par ce que la chose, comme elle est, s'estant logée la premiere dans la memoire, et s'y estant empreincte, par la voye de la connoissance, et de la science, il est malaisé qu'elle ne se représente à l'imagination, délogeant la fauceté, qui n'y peut avoir le pied si ferme, ny si rassis, et que les circonstances du premier aprentissage, se coulant à tous coups dans l'esprit, ne facent perdre le souvenir des pieces raportées, faulses ou abastardies. En ce qu'ils inventent tout à faict, d'autant qu'il n'y a nulle impression contraire, qui choque leur fauceté, ils semblent avoir d'autant moins à craindre de se mesconter. Toutesfois encore cecy, par ce que c'est un corps vain, et sans prise, eschappe volontiers à la memoire, si elle n'est bien asseurée. Dequoy j'ay souvent veu l'experience, et plaisammant, aux despens de ceux qui font profession de ne former autrement leur parole, que selon qu'il sert aux affaires qu'ils negotient, et qu'il plaist aux grands à qui ils parlent. Car ces circonstances à quoy ils veulent asservir leur foy et leur conscience, estans subjettes à plusieurs changements, il faut que leur parole se diversifie quand et quand; d'où il advient que de mesme chose ils disent gris tantost, tantost jaune; à tel homme d'une sorte, à tel d'une autre; et si par fortune ces hommes raportent en butin leurs instructions si contraires, que devient cette belle art? Outre ce qu'imprudemment ils se desferrent eux-mesme si souvent: car quelle mémoire leur pourroit suffire à se souvenir de tant de diverses formes, qu'ils ont forgées à un mesme subject? J'ay veu plusieurs de mon temps, envier la reputation de cette belle sorte de prudence, qui ne voyent pas que, si la reputation y est, l'effect n'y peut estre. En vérité le mentir est un maudit vice. Nous ne sommes hommes, et ne nous tenons les uns aux autres que par la parole. Si nous en connoissions l'horreur et le poids, nous le poursuivrions à feu plus justement que d'autres crimes. Je trouve qu'on s'amuse ordinairement à chastier aux enfans des erreurs innocentes tres mal à propos, 
et qu'on les tourmente pour des actions temeraires qui n'ont ny impression ny suitte. La menterie seule et, un peu au-dessous, l'opiniastreté me semblent estre celles desquelles on devroit à toute instance combattre la naissance et le progrez. Elles croissent quand et eux. Et depuis qu'on a donné ce faux train à la langue, c'est merveille combien il est impossible de l'en retirer. Par où il advient que nous voyons des honnestes hommes d'ailleurs, y estre subjects et asservis. J'ay un bon garçon de tailleur à qui je n'ouis jamais dire une vérité, non pas quand elle s'offre pour luy servir utilement. Si, comme la vérité, le mensonge n'avoit qu'un visage, nous serions en meilleurs termes. Car nous prenderions pour certain l'opposé de ce que diroit le menteur. Mais le revers de la verité a cent mille figures et un champ indefiny. Les Pythagoriens font le bien certain et finy, le mal infiny et incertain. Mille routtes desvoient du blanc, une y va. Certes je ne m'asseure pas que je peusse venir à bout de moy, à guarentir un danger evident et extresme par une effrontée et solemne mensonge. Un ancien pere dit que nous sommes mieux en la compagnie d'un chien cognu qu'en celle d'un homme duquel le langage nous est inconnu. Ut externus alieno non sit hominis vice. Et de combien est le langage faux moins sociable que le silence. Le Roy François premier se vantoit d'avoir mis au rouet par ce moyen Francisque Taverna, ambassadeur de François Sforce, Duc de Milan, homme tres-fameux en science de parlerie. Cettuy-cy avoit esté depesché pour excuser son maistre envers sa Majesté, d'un fait de grande consequence, qui estoit tel. Le Roy pour maintenir tousjours quelques intelligences en Italie, d'où il avoit esté dernierement chassé, mesme au Duché de Milan, avoit advisé d'y tenir pres du Duc un gentil-homme de sa part, ambassadeur par effect, mais par apparence homme privé, qui fit la mine d'y estre pour ses affaires particulieres: d'autant que le Duc, qui dependoit beaucoup plus de l'Empereur, lors principalement qu'il estoit en traicté de mariage avec sa niepce, fille du Roy de Dannemarc, qui est à present douairiere de Lorraine, ne pouvoit descouvrir avoir aucune praticque et conference avecques nous, sans son grand interest. A cette commission se trouva propre un gentil'homme Milanois, escuyer d'escurie chez le Roy, nommé Merveille. Cettuy-cy despesché avecques lettres secrettes de creance et instructions d'ambassadeur, et avecques d'autres lettres de recommandation envers le Duc en faveur de ses affaires particuliers pour le masque et la montre, fut si long temps aupres du Duc, qu'il en vint quelque resentiment à l'Empereur, qui donna cause à ce qui s'ensuivit apres, comme nous pensons: qui fut, que soubs couleur de quelque meurtre, voilà le Duc qui luy faict trancher la teste de belle nuict, et son procez faict en deux jours. Messire Francisque estant venu prest d'une longue deduction contrefaicte de cette histoire--car le Roy s'en estoit adressé, pour demander raison, à tous les princes de Chrestienté et au Duc mesmes--fut ouy aux affaires du matin, et ayant estably pour le fondement de sa cause, et dressé à cette fin, plusieurs belles apparences du faict: que son maistre n'avoit jamais pris nostre homme, que pour gentil-homme privé, et sien suject, qui estoit venu faire ses affaires à Milan, et qui n'avoit jamais vescu là soubs autre visage, desadvouant mesme avoir sceu qu'il fut en estat de la maison du Roy, ny connu de luy, tant s'en faut qu'il le prit pour ambassadeur; le Roy à son tour, le pressant de diverses objections et demandes, et le chargeant de toutes pars, l'accula en fin sur le point de l'exécution faite de nuict, et comme à la desrobée. A quoy le pauvre homme embarrassé respondit, pour faire l'honneste, que pour le respect de sa Majesté le Duc eust esté bien marry, que telle execution se fut faicte de jour. Chacun peut penser, comme il fut relevé, s'estant si lourdement couppé, et à l'endroit d'un tel nez que celuy du Roy François. Le pape Jule second ayant envoyé un ambassadeur vers le Roy d'Angleterre, pour l'animer contre le Roy François, l'ambassadeur ayant esté ouy sur sa charge, et le Roy d'Angleterre s'estant arresté en sa responce aux difficultez qu'il trouvoit à dresser les preparatifs, qu'il faudroit pour combattre un Roy si puissant, et en alleguant quelques raisons, l'ambassadeur repliqua mal à propos, qu'il les avoit aussi 
considérées de sa part, et les avoit bien dictes au Pape. De cette parole si esloingnée de sa proposition, qui estoit de le pousser incontinent à la guerre, le Roy d'Angleterre print le premier argument de ce qu'il trouva depuis par effect que cet ambassadeur, de son intention particuliere, pendoit du costé de France. Et en ayant adverty son maistre, ses biens furent confisquez, et ne tint à guere qu'il n'en perdit la vie.

\section{(I, 10, “Du Parler Prompt ou Tardif”, p. 39-40.)}

Onc ne furent à tous, toutes graces données.

Aussi voyons nous qu'au don d'eloquence, les uns ont la facilité et la promptitude, et ce qu'on dict, le boute-hors si aisé, qu'à chaque bout de champ ils sont prests; les autres plus tardifs ne parlent jamais rien qu'élabouré et premedité. comme on donne des regles aux dames de prendre les jeux et les exercices du corps selon l'advantage de ce qu'elles ont le plus beau, si j'avois à conseiller de mesmes, en ces deux divers advantages de l'eloquence, de laquelle il semble en nostre siecle que les prescheurs et les advocats facent principale profession, le tardif seroit mieux prescheur, ce me semble, et l'autre mieux advocat: par ce que la charge de celuy-là luy donne autant qu'il luy plaist de loisir pour se preparer, et puis sa carriere se passe d'un fil et d'une suite, sans interruption, là où les commoditez de l'advocat le pressent à toute heure de se mettre en lice, et les responces improuveues de sa partie adverse le rejettent hors de son branle, où il luy faut sur le champ prendre nouveau party. Si est-ce qu'à l'entreveue du Pape Clement et du Roy François à Marseille, il advint tout au rebours, que Monsieur Poyet, homme toute sa vie nourry au barreau, en grande reputation, ayant charge de faire la harangue au Pape, et l'ayant de longue main pourpensée, voire, à ce qu'on dict, apportée de Paris toute preste, le jour mesme qu'elle devoit estre prononcée, le Pape se craignant qu'on luy tint propos, qui peut offencer les ambassadeurs des autres princes, qui estoient autour de luy, manda au Roy l'argument qui luy sembloit estre le plus propre au temps et au lieu, mais de fortune tout autre que celuy sur lequel monsieur Poyet s'estoit travaillé: de façon que sa harangue demeuroit inutile, et luy en falloit promptement refaire un autre. Mais, s'en sentant incapable, il fallut que Monsieur le Cardinal du Bellay en print la charge. La part de l'Advocat est plus dificile que celle du Prescheur, et nous trouvons pourtant, ce m'est advis, plus de passables Advocats que Prescheurs, au moins en France. II semble que ce soit plus le propre de l'esprit, d'avoir son operation prompte et soudaine, et plus le propre du jugement de l'avoir lente et posée. Mais qui demeure du tout muet, s'il n'a loisir de se preparer, et celuy aussi à qui le loisir ne donne advantage de mieux dire, ils sont en pareil degré d'estrangeté. On recite de Severus Cassius qu'il disoit mieux sans y avoir pensé; qu'il devoit plus à la fortune qu'à sa diligence; qu'il luy venoit à profit d'estre troublé en parlant, et que ses adversaires craignoyent de le picquer, de peur que la colere ne luy fit redoubler son eloquence. Je cognois, par experience, cette condition de nature, qui ne peut soustenir une vehemente premeditation et laborieuse. Si elle ne va gayement et librement, elle ne va rien qui vaille. Nous disons d'aucuns ouvrages qu'ils puent l'huyle et la lampe, pour certaine aspreté et rudesse que le travail imprime en ceux où il a grande part. Mais, outre cela, la solicitude de bien faire, et cette contention de l'ame trop bandée et trop tendue à son entreprise, la met au rouet, la rompt, et l'empesche, ainsi qu'il advient à l'eau qui, par force de se presser de sa violence et abondance, ne peut trouver issue en un goulet ouvert. En cette condition de nature, de quoy je parle, il y a quant et quant aussi cela, qu'elle demande à estre non pas esbranlée et piquée par ces passions fortes, comme la colere de Cassius (car ce mouvement seroit trop aspre), elle veut estre non pas secouée, mais solicitée; elle veut estre eschaufée et reveillée par les occasions estrangeres, presentes et fortuites. Si elle va toute seule, elle ne fait que trainer et 
languir. L'agitation est sa vie et sa grace. Je ne me tiens pas bien en ma possession et disposition. Le hasard y a plus de droict que moy. L'occasion, la compaignie, le branle mesme de ma voix, tire plus de mon esprit, que je n'y trouve lors que je le sonde et employe à part moy. Ainsi les paroles en valent mieux que les escripts, s'il y peut avoir chois où il n'y a point de pris. Ceci m'advient aussi: que je ne me trouve pas où je me cherche; et me trouve plus par rencontre que par l'inquisition de mon jugement. J'aurai eslancé quelque subtilité en escrivant. (J'enten bien: mornée pour un autre, affilée pour moy. Laissons toutes ces honnestetez. Cela se dit par chacun selon sa force); je l'ay si bien perdue que je ne sçay ce que j'ay voulu dire: et l'a l'estranger descouverte par fois avant moy. Si je portoy le rasoir par tout où cela m'advient, je me desferoy tout. Le rencontre m'en offrira le jour quelque autre fois plus apparent que celuy du midy: et me fera estonner de mon hesitation.

\section{(I, 11, “Des Prognostications", p. 44.)}

Le demon de Socrates estoit à l'advanture certaine impulsion de volonté, qui se présentoit à luy, sans attendre le conseil de son discours. En une ame bien espurée, comme la sienne, et preparée par continuel exercice de sagesse et de vertu, il est vray semblable que ces inclinations, quoy que temeraires et indigestes, estoyent tousjours importantes et dignes d'estre suyvies. Chacun sent en soy quelque image de telles agitations d'une opinion prompte, véhemente et fortuite. C'est à moy de leur donner quelque authorité, qui en donne si peu à nostre prudence. Et en ay eu de pareillement foibles en raison et violentes en persuasion: ou en dissuasion, qui estoient plus ordinaires en Socrates, ausquelles je me laissay emporter si utilement et heureusement qu'elles pourroyent estre jugées tenir quelque chose d'inspiration divine.

\section{(I, 13, “Ceremonie de l'Entreveue des Roys”, p. 48.) \\ II n'est subject si vain, qui ne merite un rang en cette rapsodie.}

\section{(I, 21, “De la Force de l'Imagination”, 105-106.)}

Car les Histoires que j'emprunte, je les renvoye sur la conscience de ceux de qui je les prens. Les discours sont à moy, et se tienent par la preuve de la raison, non de l'expérience: chacun y peut joindre ses exemples: et qui n'en a point, qu'il ne laisse pas de croire qu'il en est, veu le nombre et varieté des accidens. non advenu, à Paris ou à Rome, à Jean ou à Pierre, c'est non advenu, a Paris ou a Rome, a Jean ou a Pierre, c'est toujours un tour de l'humaine capacite, duquel je suis utilement advisé par ce recit. Je le voy et en fay mon profit egalement en umbre qu'en corps. Et aux diverses leçons qu'ont souvent les histoires, je prens à me servir de celle qui est la plus rare et memorable. II y a des autheurs, desquels la fin c'est dire les evenemens. La mienne, si j'y sçavoye advenir, seroit dire sur ce qui peut advenir. II est justement permis aux escholes de supposer des similitudes, quand ils n'en ont point. Je n'en fay pas ainsi pourtant, et surpasse de ce costé là en religion superstitieuse toute foy historialle. Aux exemples que je tire ceans, de ce que j'ay ouï, faict ou dict, je me suis defendu d'oser alterer jusques aux plus legeres et inutiles circonstances. Ma conscience ne falsifie pas un iota, ma science je ne sçay. Sur ce propos, j'entre par fois en pensée qu'il puisse assez bien convenir à un Theologien, à un philosophe, et telles gens d'exquise et exacte conscience et prudence, d'escrire l'histoire. Comment peuvent ils engager leur foy sur une foy populaire? Comment respondre des pensées de personnes incognues et donner pour argent contant leurs conjectures? Des actions à divers membres, qui se passent en 
leur presence, ils refuseroient d'en rendre tesmoignage, assermentez par un juge: et n'ont homme si familier, des intentions duquel ils entreprennent de pleinement respondre. Je tien moins hazardeux d'escrire les choses passées que presentes: d'autant que l'escrivain n'a à rendre compte que d'une verité empruntée. Aucuns me convient d'escrire les affaires de mon temps, estimant que je les voy d'une veue moins blessée de passion qu'un autre, et de plus pres, pour l'accez que fortune m'a donné aux chefs de divers partis. Mais ils ne disent pas que, pour la gloire de Salluste, je n'en prendroys pas la peine: ennemy juré d'obligation, d'assiduité, de constance; qu'il n'est rien si contraire à mon stile qu'une narration estendue: je me recouppe si souvent à faute d'haleine, je n'ay ny composition, ny explication qui vaille, ignorant au-delà d'un enfant des frases et vocables qui servent aux choses plus communes; pourtant ay-je prins à dire ce que je sçay dire, accommodant la matiere à ma force; si j'en prenois qui me guidast, ma mesure pourroit faillir à la sienne; que ma liberté, estant si libre, j'eusse publié des jugemens, à mon gré mesme et selon raison, illegitimes et punissables. Plutarche nous diroit volontiers de ce qu'il en a faict, que c'est l'ouvrage d'autruy, que ses exemples soient en tout et par tout veritables; qu'ils soient utiles à la postérité, et presentez d'un lustre qui nous esclaire à la vertu, que c'est son ouvrage. II n'est pas dangereux, comme en une drogue medicinale, en un compte ancien, qu'il soit ainsin ou ainsi.

\section{(I, 24, “Divers Evenemens de Mesme Conseil”, p. 127.)}

Tant c'est chose vaine et frivole que l'humaine prudence; et au travers de tous nos projects, de nos conseils et precautions, la fortune maintient tousjours la possession des evenemens. Nous appellons les medecins heureux, quand ils arrivent à quelque bonne fin: comme s'il n'y avoit que leur art, qui ne se peut maintenir d'elle mesme, et qui eust les fondemens trop frailes pour s'appuyer de sa propre force; et comme s'il n'y avoit qu'elle, qui aye besoin que la fortune preste la main à ses operations. Je croy d'elle tout le pis ou le mieux qu'on voudra. Car nous n'avons, Dieu mercy, nul commerce ensemble: je suis au rebours des autres, car je la mesprise bien tousjours; mais quand je suis malade, au lieu d'entrer en composition, je commence encore à la haïr et à la craindre; et respons à ceux qui me pressent de prendre medecine, qu'ils attendent au moins que je sois rendu à mes forces et à ma santé, pour avoir plus de moyen de soustenir l'effort et le hazart de leur breuvage. Je laisse faire nature, et presuppose qu'elle se soit pourveue de dents et de griffes, pour se deffendre des assaux qui luy viennent, et pour maintenir cette contexture, dequoy elle fuit la dissolution. Je crain, au lieu de l'aller secourir, ainsi comme elle est aux prises bien estroites et bien jointes avec la maladie, qu'on secoure son adversaire au lieu d'elle, et qu'on la recharge de nouveaux affaires. Or je dy que, non en la medecine seulement, mais en plusieurs arts plus certaines, la fortune y a bonne part. Les saillies poetiques, qui emportent leur autheur et le ravissent hors de soy, pourquoy ne les attribuerons nous à son bon heur? puis qu'il confesse luy mesme qu'elles surpassent sa suffisance et ses forces, et les reconnoit venir d'ailleurs que de soy, et ne les avoir aucunement en sa puissance: non plus que les orateurs ne disent avoir en la leur ces mouvemens et agitations extraordinaires, qui les poussent au delà de leur dessein. II en est de mesmes en la peinture, qu'il eschappe par fois des traits de la main du peintre, surpassans sa conception et sa science, qui le tirent luy mesmes en admiration, et qui l'estonnent. Mais la fortune montre bien encores plus evidemment la part qu'elle a en tous ces ouvrages, par les graces et beautez qui s'y treuvent, non seulement sans l'intention, mais sans la cognoissance mesme de l'ouvrier. Un suffisant lecteur descouvre souvant és escrits 
d'autruy des perfections autres que celles que l'autheur y a mises et apperceues, et y preste des sens et des visages plus riches.

\section{(I, 25, "Du Pedantisme")}

Todo capítulo interessa à discussão da relação com as letras.

\section{(I, 26, “De l'Institution des Enfans")}

Todo capítulo interessa igualmente, pois nele se discute a educação que forja a suffisance.

\section{(I, 28, “De l'Amitié”, p. 183.)}

Considérant la conduite de la besongne d'un peintre que j'ay, il m'a pris envie de l'ensuivre. II choisit le plus bel endroit et milieu de chaque paroy, pour y loger un tableau élabouré de toute sa suffisance; et, le vuide tout au tour, il le remplit de crotesques, qui sont peintures fantasques, n'ayant grace qu'en la varieté et estrangeté. Que sont-ce icy aussi, à la verité, que crotesques et corps monstrueux, rappiecez de divers membres, sans certaine figure, n'ayants ordre, suite ny proportion que fortuite?

\section{Desinit in piscem mulier formosa superne.}

Je vay bien jusques à ce second point avec mon peintre, mais je demeure court en l'autre et meilleure partie: car ma suffisance ne va pas si avant que d'oser entreprendre un tableau riche, poly et formé selon l'art. Je me suis advisé d'en emprunter un d'Estienne de la Boitie, qui honorera tout le reste de cette besongne.

\section{(I, 50, “De Democritus et Heraclitus”, p. 301-302.)}

Le jugement est un util à tous subjects, et se mesle par tout. A cette cause, aux essais que j'en fay ici, j'y employe toute sorte d'occasion. Si c'est un subject que je n'entende point, à cela mesme je l'essaye, sondant le gué de bien loing; et puis, le trouvant trop profond pour ma taille, je me tiens à la rive: et cette reconnoissance de ne pouvoir passer outre, c'est un traict de son effect, voire de ceux dequoy il se vante le plus. Tantost, à un subject vain et de neant, j'essaye voir s'il trouvera dequoy lui donner corps, et dequoy l'appuyer et estançonner. Tantost je le promene à un subject noble et tracassé, auquel il n'a rien à trouver de soy, le chemin en estant si frayé qu'il ne peut marcher que sur la piste d'autruy. Là il fait son jeu à eslire la route qui luy semble la meilleure, et, de mille sentiers, il dict que cettuy-cy, ou celuy là, a esté le mieux choisi. Je prends de la fortune le premier argument. Ils me sont également bons. Et ne desseigne jamais de les produire entiers. Car je ne voy le tout de rien: Ne font pas, ceux qui promettent de nous le faire veoir. De cent membres et visages qu'a chaque chose, j'en prens un tantost à lecher seulement, tantost à effleurer; et par fois à pincer jusqu'à l'os. J'y donne une poincte, non pas le plus largement, mais le plus profondement que je sçay. Et aime plus souvent à les saisir par quelque lustre inusité. Je me hazarderoy de traitter à fons quelque matière, si je me connoissoy moins. Semant icy un mot, icy un autre, eschantillons despris de leur piece, escartez, sans dessein et sans promesse, je ne suis pas tenu d'en faire bon, ny de m'y tenir moy mesme, sans varier quand il me plaist; et me rendre au doubte et incertitude, et à ma maistresse forme, qui est l'ignorance. Tout mouvement nous descouvre. Cette mesme ame de Caesar, qui se faict voir à ordonner et dresser la bataille de Pharsale, elle se faict aussi voir à dresser des parties oysives et amoureuses. On juge un cheval, non seulement à le voir manier sur 
une carriere, mais encore à luy voir aller le pas, voire et à le voir en repos à l'estable. Entre les functions de l'ame il en est de basses: qui ne la void encor par là, n'acheve pas de la connoistre. Et à l'adventure la remarque l'on mieux où elle va son pas simple. Les vents des passions la prennent plus en ces hautes assiettes. Joint qu'elle se couche entiere sur chasque matiere, et s'y exerce entiere, et n'en traitte jamais plus d'une à la fois. Et la traitte, non selon elle, mais selon soy. Les choses à part elles ont peut estre leurs poids et mesures et conditions; mais au dedans, en nous, elle les leur taille comme elle l'entend. La mort est effroyable à Ciceron, desirable à Caton, indifferente à Socrates. La santé, la conscience, l'authorité, la science, la richesse, la beauté et leurs contraires se despouillent à l'entrée, et reçoivent de l'ame nouvelle vesture, et de la teinture qu'il lui plaist: brune, verte, claire, obscure, aigre, douce, profonde, superficielle, et qu'il plaist à chacune d'elles: car elles n'ont pas verifié en commun leurs stiles, regles et formes: chacune est Royne en son estat. Parquoy ne prenons plus excuse des externes qualitez des choses: c'est à nous à nous en rendre compte. Nostre bien et nostre mal ne tient qu'à nous. Offrons y nos offrandes et nos voeus, non pas à la fortune: elle ne peut rien sur nos meurs: au rebours, elles l'entrainent à leur suitte et la moulent à leur forme. Pourquoy ne jugeray-je d'Alexandre à table, devisant et beuvant d'autant? Ou s'il manioit des eschecs, quelle corde de son esprit ne touche et n'employe ce niais et puerille jeu? Je le hay et fuy, de ce qu'il n'est pas assez jeu, et qu'il nous esbat trop serieusement, ayant honte d'y fournir l'attention qui suffiroit à quelque bonne chose. II ne fut pas plus enbesoigné à dresser son glorieux passage aus Indes; ny cet autre à desnouer un passage duquel dépend le salut du genre humain. Voyez combien nostre ame grossit et espessit cet amusement ridicule: si tous ses nerfs ne bandent: combien amplement elle donne à chacun loy en cela, de se connoistre, et de juger droittement de soy. Je ne me voy et retaste plus universellement en nulle autre posture. Quelle passion ne nous y exerce? la cholere, le despit, la hayne, l'impatience et une vehemente ambition de vaincre, en chose en laquelle il seroit plus excusable d'estre ambitieux d'estre vaincu. Car la précellence rare et au dessus du commun messied à un homme d'honneur en chose frivole. Ce que je dy en cet exemple, se peut dire en tous autres: chasque parcelle, chasque occupation de l'homme l'accuse et le montre également qu'un' autre.

\section{(I, 56, “Des Prières”, p. 317-18 e 323.)}

Je propose des fantasies informes et irresolues, comme font ceux qui publient des questions doubteuses, à debattre aux escoles: non pour establir la verité, mais pour la chercher. Et les soubmets au jugement de ceux à qui il touche de regler, non seulement mes actions et mes escris, mais encore mes pensées. Esgalement m'en sera acceptable et utile la condemnation comme l'approbation, tenant pour execrable, s'il se trouve chose ditte par moy ignorament ou inadvertament contre les sainctes prescriptions de l'Eglise catholique, apostolique et Romaine, en laquelle je meurs et en laquelle je suis nay. Et pourtant, me remettant tousjours à l'authorité de leur censure, qui peut tout sur moy, je me mesle ainsin temerairement à toute sorte de propos, comme icy.

\section{$[\ldots]$}

Je propose les fantasies humaines et miennes, simplement comme humaines fantasies, et separement considerées, non comme arrestées et reglées par l'ordonnance celeste, 
incapables de doubte et d'altercation: matiere d'opinion, non matiere de foy; ce que je discours selon moy, non ce que je croy selon Dieu, comme les enfans proposent leurs essais: instruisables, non instruisants; d'une maniere laïque, non clericale, mais tresreligieuse tousjours.

\section{Livro II}

\section{(II, 6, “De l'exercitation”, p. 377-80.)}

Ce conte d'un évenement si legier est assez vain, n'estoit l'instruction que j'en ay tirée pour moy: car, à la verité, pour s'aprivoiser à la mort, je trouve qu'il n'y a que de s'en avoisiner. Or, comme dict Pline, chacun est à soy-mesmes une très-bonne discipline, pourveu qu'il ait la suffisance de s'espier de près. Ce n'est pas ici ma doctrine, c'est mon estude; et n'est pas la leçon d'autruy, c'est la mienne. Et ne me doibt on sçavoir mauvais gré pour tant, si je la communique. Ce qui me sert, peut aussi par accident servir à un autre. Au demeurant, je ne gaste rien, je n'use que du mien. Et, si je fay le fol, c'est à mes despends et sans l'interest de personne. Car c'est en follie qui meurt en moy, qui n'a point de suitte. Nous n'avons nouvelles que de deux ou trois anciens qui ayent battu ce chemin; et si ne pouvons dire si c'est du tout en pareille maniere à cette-cy, n'en connoissant que les noms. Nul depuis ne s'est jetté sur leur trace. C'est une espineuse entreprinse, et plus qu'il ne semble, de suyvre une alleure si vagabonde que celle de nostre esprit; de penetrer les profondeurs opaques de ses replis internes; de choisir et arrester tant de menus airs de ses agitations. Et est un amusement nouveau et extraordinaire, qui nous retire des occupations communes du monde, ouy, et des plus recommandées. II y a plusieurs années que je n'ay que moy pour visée à mes pensées, que je ne contrerolle et estudie que moy; et, si j'estudie autre chose, c'est pour soudain le coucher sur moy, ou en moy, pour mieux dire. Et ne me semble point faillir, si, comme il se faict des autres sciences, sans comparaison moins utiles, je fay part de ce que j'ay apprins en cette-cy: quoy que je ne me contente guere du progrez que j'y ai faict. II n'est description pareille en difficulté à la description de soy-mesmes, ny certes en utilité. Encore se faut-il testoner, encore se faut-il ordonner et renger pour sortir en place. Or je me pare sans cesse, car je me descris sans cesse. La coustume a faict le parler de soy vicieux, et le prohibe obstineement en hayne de la ventance qui semble tousjours estre attachée aux propres tesmoignages. Au lieu qu'on doit moucher l'enfant, cela s'appelle l'enaser. In vitium ducit culpae fuga. Je trouve plus de mal que de bien à ce remede. Mais, quand il seroit vray que ce fust necesserement presomption d'entretenir le peuple de soy, je ne doy pas, suivant mon general dessein, refuser une action qui publie cette maladive qualité, puis qu'elle est en moy; et ne doy cacher cette faute que j'ay non seulement en usage, mais en profession. Toutesfois, à dire ce que j'en croy, cette coustume a tort de condamner le vin, par ce que plusieurs s'y enyvrent. On ne peut abuser que des choses qui sont bonnes. Et croy de cette regle qu'elle ne regarde que la populaire defaillance. Ce sont brides à veaux, desquelles ny les Saincts, que nous oyons si hautement parler d'eux, ny les philosophes, ny les theologiens ne se brident. Ne fay-je, moy, quoy que je soye aussi peu l'un que l'autre. S'ils n'en escrivent à point nommé, au moins, quand l'occasion les y porte, ne feignent ils pas de se jetter bien avant sur le trottoir. Dequoy traitte Socrates plus largement que de soy? A quoy 
achemine il plus souvent les propos de ses disciples, qu'à parler d'eux, non pas de la leçon de leur livre, mais de l'estre et branle de leur ame? Nous nous disons religieusement à Dieu, et à nostre confesseur, comme noz voisins à tout le peuple. Mais nous n'en disons, me respondra-on, que les accusations. Nous disons donc tout: car nostre vertu mesme est fautiere et repentable. Mon mestier et mon art, c'est vivre. Qui me defend d'en parler selon mon sens, experience et usage, qu'il ordonne à l'architecte de parler des bastimens non selon soy, mais selon son voisin; selon la science d'un autre, non selon la sienne. Si c'est gloire de soy-mesme publier ses valeurs, que ne met Cicero en avant l'eloquence de Hortence, Hortence celle de Cicero? A l'adventure, entendent ils que je tesmoigne de moy par ouvrages et effects, non nuement par des paroles. Je peins principalement mes cogitations, subject informe, qui ne peut tomber en production ouvragere. A toute peine le puis je coucher en ce corps aerée de la voix. Des plus sages hommes et des plus devots ont vescu fuyants tous apparents effects. Les effects diroyent plus de la Fortune que de moy. Ils tesmoignent leur roole, non pas le mien, si ce n'est conjecturalement et incertainement: eschantillons d'une montre particuliere. Je m'estalle entier: c'est un Skeletos où, d'une veue, les veines, les muscles, les tendons paroissent, chaque piece en son siege. L'effect de la toux en produisoit une partie; l'effect de la palleur ou battement de coeur, un'autre, et doubteusement. Ce ne sont mes gestes que j'escris, c'est moy, c'est mon essence. Je tien qu'il faut estre prudent à estimer de soy, et pareillement consciencieux à en tesmoigner, soit bas, soit haut, indifferemment. Si je me sembloy bon et sage ou près de là, je l'entonneroy à pleine teste. De dire moins de soy qu'il n'y en a, c'est sottise, non modestie. Se payer de moins qu'on ne vaut, c'est lascheté et pusillanimité, selon Aristote. Nulle vertu ne s'ayde de la fausseté; et la verité n'est jamais matiere d'erreur. De dire de soy plus qu'il n'en y a, ce n'est pas tousjours presomption, c'est encore souvent sottise. Se complaire outre mesure de ce qu'on est, en tomber en amour de soy indiscrete, est, à mon advis, la substance de ce vice. Le supreme remede à le guarir, c'est faire tout le rebours de ce que ceus icy ordonnent, qui, en défendant le parler de soy, défendent par consequent encore plus de penser à soy. L'orgeuil gist en la pensée. La langue n'y peut avoir qu'une bien legere part. De s'amuser à soy, il leur semble que

c'est se plaire en soy; de se hanter et prattiquer, que c'est se trop cherir. II peut estre. Mais cet excez naist seulement en ceux qui ne se tastent que superficiellement; qui se voyent apres leurs affaires; qui appellent resverie et oysiveté s'entretenir de soy; et s'estoffer et bastir, faire des chasteaux en Espaigne: s'estimants chose tierce et estrangere à eux mesmes. Si quelcun s'enyvre de sa science, regardant souz soy: qu'il tourne les yeux au dessus vers les siecles passez, il baissera les cornes, y trouvant tant de milliers d'esprits qui le foulent aux pieds. S'il entre en quelque flateuse presomption de sa vaillance, qu'il se ramentoive les vies des deux Scipions, de tant d'armées, de tant de peuples, qui le laissent si loing derriere eux. Nulle particuliere qualité n'enorgeuillira celuy qui mettra quand et quand en compte tant de imparfaittes et foibles qualitez autres qui sont en luy, et, au bout, la nihilité de l'humaine condition. Par ce que Socrates avoit seul mordu à certes au precepte de son Dieu, de se connoistre, et par cette estude estoit arrivé à se mespriser, il fut estimé seul digne du surnom de Sage. Qui se connoistra ainsi, qu'il se donne hardiment à connoistre par sa bouche.

\section{(II, 8, “De l'Affection des Pères aux Enfans”, p. 385-86; 387-88; 399-402.)}

A Madame d'Estissac. Madame, si l'estrangeté ne me sauve, et la nouvelleté, qui ont accoustumé de donner pris aux choses, je ne sors jamais à mon honneur de cette sotte 
entreprise; mais elle est si fantastique et a un visage si esloigné de l'usage commun que cela luy pourra donner passage. C'est une humeur melancolique, et une humeur par consequent tres ennemie de ma complexion naturelle, produite par le chagrin de la solitude en laquelle il y a quelques années que je m'estoy jetté, qui m'a mis premierement en teste cette resverie de me mesler d'escrire. Et puis, me trouvant entierement despourveu et vuide de toute autre matiere, je me suis presenté moymesmes à moy, pour argument et pour subject. C'est le seul livre au monde de son espece, d'un dessein farouche et extravagant. II n'y a rien aussi en cette besoingne digne d'estre remerqué que cette bizarrerie: car à un subject si vain et si vile le meilleur ouvrier du monde n'eust sçeu donner façon qui merite qu'on en face conte. Or, Madame, ayant à m'y pourtraire au vif, j'en eusse oublié un traict d'importance, si je n'y eusse representé l'honneur que j'ay tousjours rendu à vos merites.

\section{$[\ldots]$}

Joint cette autre consideration Aristotelique, que celuy qui bien faict à quelcun, l'aime mieus qu'il n'en est aimé; et celuy à qui il est deu, aime mieus que celuy qui doibt; et tout ouvrier mieus son ouvrage qu'il n'en seroit aimé, si l'ouvrage avoit du sentiment. D'autant que nous avons cher, estre; et estre consiste en mouvement et action. Parquoy chascun est aucunement en son ouvrage. Qui bien faict, exerce une action belle et honneste; qui reçoit, l'exerce utile seulement; or l'utile est de beaucoup moins aimable que l'honneste. L'honneste est stable et permanent, fournissant à celuy qui l'a faict, une gratification constante. L'utile se perd et eschappe facilement; et n'en est la memoire ny si fresche ny si douce. Les choses nous sont plus cheres, qui nous ont plus cousté; et il est plus difficile de donner que de prendre. Puisqu'il a pleu à Dieu nous douer de quelque capacité de discours, affin que, comme les bestes, nous ne fussions pas servilement assujectis aux loix communes, ains que nous nous y appliquassions par jugement et liberté volontaire, nous devons bien prester un peu à la simple authorité de nature, mais non pas nous laisser tyranniquement emporter à elle; la seule raison doit avoir la conduite de nos inclinations. J'ay, de ma part, le goust estrangement mousse à ces propensions qui sont produites en nous sans l'ordonnance et entremise de nostre jugement.

\section{$[\ldots]$}

Or, à considerer cette simple occasion d'aymer nos enfans pour les avoir engendrez, pour laquelle nous les appellons autres nous mesmes, il semble qu'il y ait bien une autre production venant de nous, qui ne soit pas de moindre recommandation: car ce que nous engendrons par l'ame, les enfantemens de nostre esprit, de nostre courage et suffisance, sont produicts par une plus noble partie que la corporelle, et sont plus nostres; nous sommes pere et mere ensemble en cette generation; ceux cy nous coustent bien plus cher, et nous apportent plus d'honeur, s'ils ont quelque chose de bon. Car la valeur de nos autres enfans est beaucoup plus leur que nostre; la part que nous y avons est bien legiere; mais de ceux cy toute la beauté, toute la grace et pris est nostre. Par ainsin, ils nous representent et nous rapportent bien plus vivement que les autres. Platon adjouste que ce sont icy des enfans immortels, qui immortalisent leurs peres, voire et les deïfient, comme à Lycurgus, à Solon, à Minos. Or, les Histoires estant pleines d'exemples de cette amitié commune des peres envers les enfans, il ne m'a pas semblé hors de propos d'en tirer aussi quelcun de cette cy. Heliodorus, ce bon Evesque de Tricea, ayma mieux perdre la dignité, le profit, la devotion d'une prelature si 
venerable, que de perdre sa fille, fille qui dure encore, bien gentille, mais à l'adventure pourtant un peu trop curieusement et mollement goderonnée pour fille ecclesiastique et sacerdotale, et de trop amoureuse façon. II y eut un Labienus à Rome, personnage de grande valeur et authorité, et, entre autres qualitez, excellent en toute sorte de literature, qui estoit, ce croy-je, fils de ce grand Labienus, le premier des capitaines qui furent soubs Caesar en la guerre des Gaules, et qui, depuis, s'estant jetté au party du grand Pompeius, s'y maintint si valeureusement jusques à ce que Caesar le deffit en Espaigne. Ce Labienus dequoy je parle, eust plusieurs envieux de sa vertu, et, comme il est vray semblable, les courtisans et favoris des Empereurs de son temps pour ennemis de sa franchise et des humeurs paternelles qu'il retenoit encore contre la tyrannie, desquelles il est croyable qu'il avoit teint ses escrits et ses livres. Ses adversaires poursuivirent devant le magistrat à Rome, et obtindrent de faire condamner plusieurs siens ouvrages, qu'il avoit mis en lumiere, à estre bruslés. Ce fut par luy que commença ce nouvel exemple de peine, qui, dépuis, fut continué à Rome à plusieurs autres, de punir de mort les escrits mesmes et les estudes. II n'y avoit point assez de moyen et matiere de cruauté, si nous n'y meslions des choses que nature a exemptées de tout sentiment et de toute souffrance, comme la reputation et les inventions de nostre esprit, et si nous n'alions communiquer les maux corporels aux disciplines et monumens des Muses. Or Labienus ne peut souffrir cette perte, ny de survivre à cette sienne si chere geniture; il se fit porter et enfermer tout vif dans le monument de ses ancestres, là où il pourveut tout d'un train à se tuer et à s'enterrer ensemble. II est malaisé de montrer aucune autre plus vehemente affection paternelle que celle là. Cassius Severus, homme tres-eloquent et son familier, voyant brusler ses livres, crioit que, par mesme sentence, on le devoit quant et quant condamner à estre bruslé tout vif: car il portoit et conservoit en sa memoire ce qu'ils contenoient. Pareil accident advint à Greuntius Cordus, accusé d'avoir en ses livres loué Brutus et Cassius. Ce senat vilain, servile et corrompu, et digne d'un pire maistre que Tibere, condamna ses escripts au feu; il fut content de faire compaignie à leur mort, et se tua par abstinence de manger. Le bon Lucanus estant jugé par ce coquin de Neron, sur les derniers traits de sa vie, comme la pluspart du sang fut desjà escoulé par les veines des bras qu'il s'estoit faictes tailler à son medecin pour mourir, et que la froideur eut saisi les extremitez de ses membres et commençat à approcher des parties vitales, la derniere chose qu'il eut en sa memoire, ce furent aucuns des vers de son livre de la guerre de Pharsale, qu'il recitoit; et mourut ayant cette derniere voix en la bouche. Cela, qu'estoit ce qu'un tendre et paternel congé qu'il prenoit de ses enfans, representant les a-dieux et les estroits embrassemens que nous donnons aux nostres en mourant, et un effet de cette naturelle inclination qui r'appelle en nostre souvenance, en cette extremité, les choses que nous avons eu les plus cheres pendant nostre vie? Pensons nous qu'Epicurus qui, en mourant, tourmenté, comme il dit, des extremes douleurs de la colique, avoit toute sa consolation en la beauté de sa doctrine qu'il laissoit au monde, eut receu autant de contentement d'un nombre d'enfans bien nais et bien eslevez, s'il en eust eu, comme il faisoit de la production de ses riches escrits? et que, s'il eust esté au chois de laisser apres luy un enfant contrefaict et mal nay, ou un livre sot et inepte, il ne choisit plustost, et non luy seulement, mais tout homme de pareille suffisance, d'encourir le premier mal'heur que l'autre? Ce seroit à l'adventure impieté en Sainct Augustin (pour exemple) si d'un costé on luy proposoit d'enterrer ses escrits, dequoy nostre religion reçoit un si grand fruit, ou d'enterrer ses enfans, au cas qu'il en eut, s'il n'aimoit mieux enterrer ses enfans. Et je ne sçay si je n'aimerois pas mieux beaucoup en avoir produict ung, parfaictement bien formé, de l'acointance des muses, que de l'acointance de ma femme. A cettuy-cy, tel qu'il est, ce que je donne, je le donne purement et irrevocablement, comme on donne aux enfans corporels: ce peu de bien que je luy ay faict, il n'est plus en ma disposition; il 
peut sçavoir assez de choses que je ne sçay plus, et tenir de moy ce que je n'ay point retenu et qu'il faudroit que, tout ainsi qu'un estranger, j'empruntasse de luy, si besoin m'en venoit. II est plus riche que moy, si je suis plus sage que luy. II est peu d'hommes addonez à la poesie, qui ne se gratifiassent plus d'estre peres de l'Eneide que du plus beau garçon de Rome, et qui ne souffrissent plus aiséement l'une perte que l'autre. Car, selon Aristote, de tous les ouvriers, le poete nomméement est le plus amoureux de son ouvrage. II est malaisé à croire qu'Epaminondas, qui se vantoit de laisser pour toute posterité des filles qui feroyent un jour honneur à leur pere (c'estoyent les deux nobles victoires qu'il avoit gaigné sur les Lacedemoniens), eust volontiers consenty à échanger celles là aux plus gorgiases de toute la Grece, ou que Alexandre et Caesar ayent jamais souhaité d'estre privez de la grandeur de leurs glorieux faicts de guerre, pour la commodité d'avoir des enfans et heritiers, quelques parfaits et accompliz qu'ils peussent estre; voire je fay grand doubte que Phidias, ou autre excellent statuere, aymat autant la conservation et la durée de ses enfans naturels, comme il feroit d'une image excellente qu'avec long travail et estude il auroit parfaite selon l'art. Et, quant à ces passions vitieuses et furieuses qui ont eschauffé quelque fois les peres à l'amour de leurs filles, ou les meres envers leurs fils, encore s'en trouve il de pareilles en cette autre sorte de parenté: tesmoing ce que l'on recite de Pygmalion, qui, ayant basty une statue de femme de beauté singuliere, il devint si éperduement espris de l'amour forcené de ce sien ouvrage, qu'il falut qu'en faveur de sa rage les dieux la luy vivifiassent,

Tentatum mollescit ebur, positoque rigore

Subsedit digitis.

\section{(II, 17, “De la Praesumption”)}

Todo capítulo interessa à discussão do problema de compor um retrato de si.

\section{(II, 37, “De la Ressemblance des Enfans aux Peres”, p. 758-59; 783-85.)}

Ce fagotage de tant de diverses pieces se faict en cette condition, que je n'y mets la main que lors qu'une trop lasche oisiveté me presse, et non ailleurs que chez moy. Ainsin il s'est basty à diverses poses et intervalles, comme les occasions me detiennent ailleurs par fois plusieurs moys. Au demeurant, je ne corrige point mes premieres imaginations par les secondes; ouy à l'aventure quelque mot, mais pour diversifier, non pour oster. Je veux representer le progrez de mes humeurs, et qu'on voye chaque piece en sa naissance. Je prendrois plaisir d'avoir commencé plus-tost et à reconnoistre le trein de mes mutations. Un valet qui me servoit à les escrire soubs moy pensa faire un grand butin de m'en desrober plusieurs pieces choisies à sa poste. Cela me console qu'il n'y fera pas plus de gain que j'y ay fait de perte. Je me suis envieilly de sept ou huict ans depuis que je commençay: ce n'a pas esté sans quelque nouvel acquest. J'y ay pratiqué la colique par la liberalité des ans. Leur commerce et longue conversation ne se passe aisément sans quelque tel fruit.

\section{$[\ldots]$}

A Madame de Duras

Madame, vous me trouvates sur ce pas dernierement que vous me vintes voir. Par ce qu'il pourra estre que ces inepties se rencontreront quelque fois entre vos mains, je veux 
aussi qu'elles portent tesmoignage que l'autheur se sent bien fort honoré de la faveur que vous leur ferez. Vous y reconnoistrez ce mesme port et ce mesme air que vous avez veu en sa conversation. Quand j'eusse peu prendre quelque autre façon que la mienne ordinaire et quelque autre forme plus honorable et meilleure, je ne l'eusse pas faict; car je ne veux tirer de ces escrits sinon qu'ils me representent à vostre memoire au naturel. Ces mesmes conditions et facultez, que vous avez pratiquées et receuillies, Madame, avec beaucoup plus d'honneur et de courtoisie qu'elles ne meritent, je les veux loger (mais sans alteration et changement) en un corps solide qui puisse durer quelques années ou quelques jours apres moy, où vous les retrouverez, quand il vous plaira vous en refreschir la memoire, sans prendre autrement la peine de vous en souvenir: aussi ne le valent elles pas. Je desire que vous continuez en moy la faveur de vostre amitié, par ces mesmes qualitez par le moyen desquelles elle a esté produite. Je ne cherche aucunement qu'on m'ayme et estime mieux mort que vivant. L'humeur de Tibere est ridicule, et commune pourtant, qui avoit plus de soin d'estendre sa renommée à l'advenir qu'il n'avoit de se rendre estimable et agreable aux hommes de son temps. Si j'estoy de ceux à qui le monde peut devoir louange, je l'en quitteroy et qu'il me la payast d'advance; qu'elle se hastat et amoncelat toute autour de moy, plus espesse qu'alongée, plus pleine que durable; et qu'elle s'evanouit hardiment quand et ma cognoissance, et que ce doux son ne touchera plus mes oreilles. Ce seroit une sotte humeur d'aller, à cette heure que je suis prest d'abandonner le commerce des hommes, me produire à eux par une nouvelle recommandation. Je ne fay nulle recepte des biens que je n'ay peu employer à l'usage de ma vie. Quel que je soye, je le veux estre ailleurs qu'en papier. Mon art et mon industrie ont esté employez à me faire valoir moy-mesme; mes estudes, à m'apprendre à faire, non pas à escrire. J'ay mis tous mes efforts à former ma vie. Voylà mon mestier et mon ouvrage. Je suis moins faiseur de livres que de nulle autre besoigne. J'ay desiré de la suffisance pour le service de mes commoditez presentes et essentielles, non pour en faire magasin et reserve à mes heritiers. Qui a de la valeur, si le face paroistre en ses meurs, en ses propos ordinaires, à traicter l'amour ou des querelles, au jeu, au lict, à la table, à la conduite de ses affaires, et oeconomie de sa maison. Ceux que je voi faire des bons livres sous des mechantes chausses, eussent premierement faict leurs chausses, s'ils m'en eussent creu. Demandez à un Spartiate s'il aime mieux estre bon rhetoricien que bon soldat; non pas moy, que bon cuisinier, si je n'avois qui m'en servist. Mon Dieu ! Madame, que je haïrois une telle recommandation d'estre habile homme par escrit, et estre un homme de neant et un sot ailleurs. J'ayme mieux encore estre un sot, et icy et là, que d'avoir si mal choisi où employer ma valeur. Aussi il s'en faut tant que j'attende à me faire quelque nouvel honneur par ces sotises, que je feray beaucoup si je n'y en pers point de ce peu que j'en avois aquis. Car, outre ce que cette peinture morte et muete desrobera à mon estre naturel, elle ne se raporte pas à mon meilleur estat, mais beaucoup descheu de ma premiere vigueur et allegresse, tirant sur le flestry et le rance. Je suis sur le fond du vaisseau, qui sent tantost le bas et la lye. Au demeurant, Madame, je n'eusse pas osé remuer si hardiment les misteres de la medecine, attendu le credit que vous et tant d'autres luy donnez, si je n'y eusse esté acheminé par ses autheurs mesme. Je croy qu'ils n'en ont que deux anciens Latins, Pline et Celsus. Si vous les voyez quelque jour, vous trouverez qu'ils parlent bien plus rudement à leur art que je ne fay: je ne fay que la pincer, ils l'esgorgent. Pline se mocque, entre autres choses, dequoy, quand ils sont au bout de leur corde, ils ont inventé cette belle deffaite de r'envoyer les malades qu'ils ont agitez et tormentez pour neant de leurs drogues et regimes, les uns au secours des voeuz et miracles, les autres aux eaux chaudes. (Ne vous courroussez pas, Madame, il ne parle pas de celles de deçà qui sont soubs la protection de vostre maison, et qui sont toutes Gramontoises). Ils ont une tierce deffaite pour nous chasser d'aupres d'eux et se 
descharger des reproches que nous leur pouvons faire du peu d'amendement à noz maux, qu'ils ont eu si long temps en gouvernement qu'il ne leur reste plus aucune invention à nous amuser: c'est de nous envoier cercher la bonté de l'air de quelque autre contrée. Madame, en voylà assez: vous me donnez bien congé de reprendre le fil de mon propos, duquel je m'estoy destourné pour vous entretenir.

\section{Livro III}

\section{(III, 1, “De I'Utile et de l'Honneste”, p. 790-92.)}

Personne n'est exempt de dire des fadaises. Le malheur est de les dire curieusement.

Nae iste magno conatu magnas nugas dixerit.

Cela ne me touche pas. Les miennes m'eschappent aussi nonchallamment qu'elles le valent. D'où bien leur prend. Je les quitterois soudain, à peu de coust qu'il y eust. Et ne les achette, ny les vens que ce qu'elles poisent. Je parle au papier comme je parle au premier que je rencontre. Qu'il soit vray, voicy dequoy.

[...] En ce peu que j'ay eu à negotier entre nos Princes, en ces divisions et subdivisions qui nous deschirent aujourd'hui, j'ay curieusement evité qu'ils se mesprinssent en moy et s'enferrassent en mon masque. Les gens du mestier se tiennent les plus couverts, et se presentent et contrefont les plus moyens et les plus voisins qu'ils peuvent. Moy, je m'offre par mes opinions les plus vives et par la forme plus mienne. Tendre negotiateur et novice, qui ayme mieux faillir à l'affaire qu'à moy ! C'a esté pourtant jusques à cette heure avec tel heur (car certes la fortune y a principalle part) que peu ont passé de main à autre avec moins de soubçon, plus de faveur et de privauté. J'ay une façon ouverte, aisée à s'insinuer et à se donner credit aux premieres accointances. La naifveté et la verité pure, en quelque siecle que ce soit, trouvent encore leur opportunité et leur mise. Et puis, de ceux-là est la liberté peu suspecte et peu odieuse, qui besoingnent sans aucun leur interest, et qui peuvent veritablement employer la responce de Hipperides aux Atheniens se plaignans de l'aspreté de son parler: Messieurs, ne considerez pas si je suis libre, mais si je le suis sans rien prendre et sans amender par là mes affaires. Ma liberté m'a aussi aiséement deschargé du soubçon de faintise par sa vigueur (n'espargnant rien à dire pour poisant et cuisant qu'il fut, je n'eusse peu dire pis, absent) et qu'elle a une montre apparente de simplesse et de nonchalance. Je ne pretens autre fruict en agissant, que d'agir, et n'y attache longues suittes et propositions: chasque action fait particulierement son jeu : porte s'il peut.

\section{(III, 2, “Du Repentir”, p. 804-06.)}

Les autres forment l'homme; je le recite et en represente un particulier bien mal formé, et lequel, si j'avoy à façonner de nouveau, je ferois vrayement bien autre qu'il n'est. Meshuy c'est fait. Or les traits de ma peinture ne forvoyent point, quoy qu'ils se changent et diversifient. Le monde n'est qu'une branloire perenne. Toutes choses y branlent sans cesse: la terre, les rochers du Caucase, les pyramides d'Aegypte, et du branle public et du leur. La constance mesme n'est autre chose qu'un branle plus languissant. Je ne puis asseurer mon object. II va trouble et chancelant, d'une yvresse naturelle. Je le 
prens en ce point, comme il est, en l'instant que je m'amuse à luy. Je ne peints pas l'estre. Je peints le passage : non un passage d'aage en autre, ou, comme dict le peuple, de sept en sept ans, mais de jour en jour, de minute en minute. II faut accommoder mon histoire à l'heure. Je pourray tantost changer, non de fortune seulement, mais aussi d'intention. C'est un contrerolle de divers et muables accidens et d'imaginations irresolues et, quand il y eschet, contraires: soit que je sois autre moymesme, soit que je saisisse les subjects par autres circonstances et considerations. Tant y a que je me contredits bien à l'adventure, mais la verité, comme disoit Demades, je ne la contredy point. Si mon ame pouvoit prendre pied, je ne m'essaierois pas, je me resoudrois: elle est tousjours en apprentissage et en espreuve. Je propose une vie basse et sans lustre, c'est tout un. On attache aussi bien toute la philosophie morale à une vie populaire et privée que à une vie de plus riche estoffe: chaque homme porte la forme entiere de l'humaine condition. Les autheurs se communiquent au peuple par quelque marque particuliere et estrangere; moy le premier par mon estre universel, comme Michel de Montaigne, non comme grammairien ou poete ou jurisconsulte. Si le monde se plaint de quoy je parle trop de moy, je me plains de quoy il ne pense seulement pas à soy. Mais est-ce raison que, si particulier en usage, je pretende me rendre public en cognoissance? Est-il aussi raison que je produise au monde, où la façon et l'art ont tant de credit et de commandement, des effects de nature crus et simples, et d'une nature encore bien foiblette? Est-ce pas faire une muraille sans pierre, ou chose semblable, que de bastir des livres sans science et sans art? Les fantasies de la musique sont conduictes par art, les miennes par sort. Au-moins j'ay cecy selon la discipline, que jamais homme ne traicta subject qu'il entendit ne cogneust mieux que je fay celuy que j'ay entrepris, et qu'en celuy-là je suis le plus sçavant homme qui vive; secondement, que jamais aucun ne penetra en sa matiere plus avant, ny en esplucha plus particulierement les membres et suites; et n'arriva plus exactement et plainement à la fin qu'il s'estoit proposé à sa besoingne. Pour la parfaire, je n'ay besoing d'y apporter que la fidelité: celle-là y est, la plus sincere et pure qui se trouve. Je dy vray, non pas tout mon saoul, mais autant que je l'ose dire; et l'ose un peu plus en vieillissant, car il semble que la coustume concede à cet aage plus de liberté de bavasser et d'indiscretion à parler de soy. II ne peut advenir icy ce que je voy advenir souvent, que l'artizan et sa besoigne se contrarient: un homme de si honneste conversation a-il faict un si sot escrit? ou, des escrits si sçavans sont-ils partis d'un homme de si foible conversation? Qui a un entretien commun et ses escrits rares, c'est à dire que sa capacité est en lieu d'où il l'emprunte, et non en luy. Un personage sçavant n'est pas sçavant par tout; mais le suffisant est par tout suffisant, et à ignorer mesme. Icy, nous allons conformément et tout d'un trein, mon livre et moy. Ailleurs, on peut recommander et accuser l'ouvrage à part de l'ouvrier; icy, non : qui touche l'un, touche l'autre. Celuy qui en jugera sans le connoistre, se fera plus de tort qu'à moy; celuy qui l'aura conneu, m'a du tout satisfaict. Heureux outre mon merite, si j'ay seulement cette part à l'approbation publique, que je face sentir aux gens d'entendement que j'estoy capable de faire mon profit de la science, si j'en eusse eu, et que je meritoy que la memoire me secourut mieux.

\section{(III, 5, "Sur des vers de Virgile”, p. 872-77; 887-88.)}

[...] Ce que Virgile dict de Venus et de Vulcan, Lucrece l'avoit dict plus sortablement d'une jouissance desrobée d'elle et de Mars:

belli fera moenera Mavors

Armipotens regit, in gremium qui saepe tuum se

Rejicit, aeterno devinctus vulnere amoris: 
Pascit amore avidos inhians in te, Dea, visus,

Eque tuo pendet resupini spiritus ore:

Hunc tu, diva, tuo recubantem corpore sancto

Circunfusa super, suaveis ex ore loquelas

Funde.

Quand je rumine ce rejicit, pascit, inhians, molli, fovet, medullas, labefacta, pendet, percurrit, et cette noble circunfusa, mere du gentil infusus, j'ay desdain de ces menues pointes et allusions verballes qui nasquirent depuis. A ces bonnes gens, il ne falloit pas d'aigue et subtile rencontre: leur langage est tout plein et gros d'une vigueur naturelle et constante; ils sont tout epigramme, non la queue seulement, mais la teste, l'estomac et les pieds. II n'y a rien d'efforcé, rien de treinant, tout y marche d'une pareille teneur. Contextus totus virilis est; non sunt circa flosculos occupati. Ce n'est pas une eloquence molle et seulement sans offence: elle est nerveuse et solide, qui ne plaict pas tant comme elle remplit et ravit, et ravit le plus les plus forts espris. Quand je voy ces braves formes de s'expliquer, si vifves, si profondes, je ne dicts pas que c'est bien dire, je dicts que c'est bien penser. C'est la gaillardise de l'imagination qui esleve et enfle les parolles. Pectus est quod disertum facit. Nos gens appellent jugement, langage; et beaux mots, les plaines conceptions. Cette peinture est conduitte non tant par dexterité de la main comme pour avoir l'object plus vifvement empreint en l'ame. Gallus parle simplement, par ce qu'il conçoit simplement. Horace ne se contente point d'une superficielle expression, elle le trahiroit. II voit plus cler et plus outre dans la chose; son esprit crochette et furette tout le magasin des mots et des figures pour se représenter; et les luy faut outre l'ordinaire, comme sa conception est outre l'ordinaire. Plutarque dit qu'il veid le langage latin par les choses; icy de mesme : le sens esclaire et produict les parolles; non plus de vent, ains de chair et d'os. Elles signifient plus qu'elles ne disent. Les imbecilles sentent encores quelque image de cecy: car, en Italie, je disois ce qu'il me plaisoit en devis communs; mais, aus propos roides, je n'eusse osé me fier à un Idiome que je ne pouvois plier ny contourner outre son alleure commune. J'y veux pouvoir quelque chose du mien. Le maniement et emploite des beaux espris donne pris à la langue, non pas l'innovant tant comme la remplissant de plus vigoreux et divers services, l'estirant et ployant. Ils n'y aportent point des mots, mais ils enrichissent les leurs, appesantissent et enfoncent leur signification et leur usage, luy aprenent des mouvements inaccoustumés, mais prudemment et ingenieusement. Et combien peu cela soit donné à tous, il se voit par tant d'escrivains françois de ce siecle. Ils sont assez hardis et dédaigneux pour ne suyvre la route commune; mais faute d'invention et de discretion les pert. II ne s'y voit qu'une miserable affectation d'estrangeté, des déguisements froids et absurdes qui, au lieu d'eslever, abbattent la matiere. Pourveu qu'ils se gorgiasent en la nouvelleté, il ne leur chaut de l'efficace: pour saisir un nouveau mot, ils quittent l'ordinaire, souvent plus fort et plus nerveux. En nostre langage je trouve assez d'estoffe, mais un peu faute de façon: car il n'est rien qu'on ne fit du jargon de nos chasses et de nostre guerre, qui est un genereux terrein à emprunter; et les formes de parler, comme les herbes, s'amendent et fortifient en les transplantant. Je le trouve suffisamment abondant, mais non pas maniant et vigoureux suffisamment. II succombe ordinairement à une puissante conception. Si vous allez tendu, vous sentez souvent qu'il languit soubs vous et fleschit, et qu'à son deffaut le Latin se presente au secours, et le Grec à d'autres. D'aucuns de ces mots que je viens de trier, nous en apercevons plus malaisément l'energie, d'autant que l'usage et la frequence nous en ont aucunement avily et rendu vulgaire la grace. Comme en nostre commun, il s'y rencontre des frases excellentes et des metaphores desquelles la beauté flestrit de vieillesse, et la couleur s'est ternie par maniement trop ordinaire. Mais cela n'oste rien du goust à ceux qui ont bon nez, ny ne desroge à la gloire de ces anciens autheurs qui, comme il est 
vraysemblable, mirent premierement ces mots en ce lustre. Les sciences traictent les choses trop finement, d'une mode trop artificielle et differente à la commune et naturelle. Mon page faict l'amour et l'entend. Lisez luy Leon Hébreu et Ficin: on parle de luy, de ses pensées et de ses actions, et si il n'y entend rien. Je ne recognois pas chez Aristote la plus part de mes mouvemens ordinaires: on les a couverts et revestus d'une autre robbe pour l'usage de l'eschole. Dieu leur doint bien faire ! Si j'estois du mestier, je naturaliserois l'art autant comme ils artialisent la nature. Laissons là Bembo et Equicola. Quand j'escris, je me passe bien de la compaignie et souvenance des livres, de peur qu'ils n'interrompent ma forme. Aussi que, à la verité, les bons autheurs m'abattent par trop et rompent le courage. Je fais volontiers le tour de ce peintre, lequel, ayant miserablement representé des coqs, deffendoit à ses garçons qu'ils ne laissassent venir en sa boutique aucun coq naturel. Et auroy plustost besoing, pour me donner un peu de lustre, de l'invention du musicien Antinonydes qui, quand il avoit à faire la musique, mettoit ordre que devant ou apres luy son auditoire fut abreuvé de quelques autres mauvais chantres. Mais je me puis plus malaiséement deffaire de Plutarque. II est si universel et si plain qu'à toutes occasions, et quelque suject extravagant que vous ayez pris, il s'ingere à vostre besongne et vous tend une main liberale et inespuisable de richesses et d'embellissemens. II m'en faict despit d'estre si fort exposé au pillage de ceux qui le hantent: je ne le puis si peu racointer que je n'en tire cuisse ou aile. Pour ce mien dessein, il me vient aussi à propos d'escrire chez moy, en pays sauvage, où personne ne m'ayde ny me releve, où je ne hante communéement homme qui entende le latin de son patenostre, et de françois un peu moins. Je l'eusse faict meilleur ailleurs, mais l'ouvrage eust esté moins mien; et sa fin principale et perfection, c'est d'estre exactement mien. Je corrigerois bien une erreur accidentale, dequoy je suis plain, ainsi que je cours inadvertemment; mais les imperfections qui sont en moy ordinaires et constantes, ce seroit trahison de les oster. Quand on m'a dit ou que moy-mesme me suis dict: Tu es trop espais en figures. Voilà un mot du creu de Gascoingne. Voilà une frase dangereuse (je n'en refuis aucune de celles qui s'usent emmy les rues françoises; ceux qui veulent combatre l'usage par la grammaire se moquent). Voilà un discours ignorant. Voilà un discours paradoxe. En voilà un trop fol. Tu te joues souvent; on estimera que tu dies à droit, ce que tu dis à feinte.-- Oui, fais-je ; mais je corrige les fautes d'inadvertence, non celles de coustume. Est-ce pas ainsi que je parle par tout? me represente-je pas vivement ? suffit ! J'ay faict ce que j'ay voulu: tout le monde me reconnoit en mon livre, et mon livre en moy. Or j'ay une condition singeresse et imitatrice: quand je me meslois de faire des vers (et n'en fis jamais que des Latins), ils accusoient evidemment le poete que je venois dernierement de lire; et, de mes premiers essays, aucuns puent un peu à l'estranger. A Paris, je parle un langage aucunement autre qu'à Montaigne. Qui que je regarde avec attention m'imprime facilement quelque chose du sien. Ce que je considere, je l'usurpe: une sotte contenance, une desplaisante grimace, une forme de parler ridicule. Les vices, plus : d'autant qu'ils me poingnent, ils s'acrochent à moy et ne s'en vont pas sans secouer. On m'a veu plus souvent jurer par similitude que par complexion. Imitation meurtriere comme celle des singes horribles en grandeur et en force que le Roy Alexandre rencontra en certaine contrée des Indes. Desquels autrement il eust esté difficile de venir à bout. Mais ils en prestarent le moyen par cette leur inclination à contrefaire tout ce qu'ils voyoyent faire. Car par là les chasseurs apprindrent de se chausser des souliers à leur veue à tout force noeuds de liens; de s'affubler d'acoustrements de testes à tout des lacs courants et oindre par semblant leurs yeux de glux. Ainsi mettoit imprudemment à mal ces pauvres bestes leur complexion singeresse. Ils s'engluoient, enchevestroyent et garrotoyent d'elles mesmes. Cette autre faculté de representer ingenieusement les gestes et parolles d'un autre par dessein, qui apporte souvent plaisir et admiration, n'est en moy non plus qu'en une 
souche. Quand je jure selon moy, c'est seulement: par Dieu, qui est le plus droit de tous les serments. Ils disent que Socrates juroit le chien, Zenon cette mesme interjection qui sert à cette heure aux Italiens, Cappari ; Pythagoras l'eau et l'air. Je suis si aisé à recevoir, sans y penser, ces impressions superficielles, qu'ayant eu en la bouche Sire ou altesse trois jours de suite, huict jours apres ils m'eschappent pour excellence ou pour seigneurie. Et ce que j'auray pris à dire en battellant et en me moquant, je le diray lendemain serieusement. Parquoy, à escrire, j'accepte plus envis les arguments battus, de peur que je les traicte aux despens d'autruy. Tout argument m'est egallement fertille. Je les prens sur une mouche; et Dieu veuille que celuy que j'ay icy en main n'ait pas esté pris par le commandement d'une volonté autant volage! Que je commence par celle qu'il me plaira, car les matieres se tiennent toutes enchesnées les unes aux autres. Mais mon ame me desplait de ce qu'elle produict ordinairement ses plus profondes resveries, plus folles et qui me plaisent le mieux, à l'improuveu et lors que je les cerche moins; lesquelles s'esvanouissent soudain, n'ayant sur le champ où les attacher: à cheval, à la table, au lit, mais plus à cheval, où sont mes plus larges entretiens. J'ay le parler un peu delicatement jaloux d'attention et de silence, si je parle de force: qui m'interrompt m'arreste. En voiage, la necessité mesme des chemins couppe les propos; outre ce, que je voyage plus souvent sans compaignie propre à ces entretiens de suite, par où je prens tout loisir de m'entretenir moy-mesme. II m'en advient comme de mes songes: en songeant, je les recommande à ma memoire (car je songe volontiers que je songe), mais le lendemain je me represente bien leur couleur comme elle estoit, ou gaye, ou triste, ou estrange; mais quels ils estoient au reste, plus j'ahane à le trouver, plus je l'enfonce en l'oubliance. Aussi de ces discours fortuites qui me tombent en fantasie, il ne m'en reste en memoire qu'une vaine image, autant seulement qu'il m'en faut pour me faire ronger et despiter apres leur queste, inutilement. Or donc, laissant les livres à part, parlant plus materiellement et simplement, je trouve [...]

[...] Chacune de mes pieces me faict esgalement moy que toute autre. Et nulle autre ne me faict plus proprement homme que cette cy. Je dois au publiq universellement mon pourtrait. La sagesse de ma leçon est en verité, en liberté, en essence, toute; desdeignant, au rolle de ses vrays devoirs, ces petites regles feintes, usuelles, provinciales; naturelle toute, constante, universelle, de laquelle sont filles, mais bastardes, la civilité, la ceremonie. Nous aurons bien les vices de l'apparence, quand nous aurons eu ceux de l'essence. Quand nous aurons faict à ceux icy, nous courrons sus aux autres, si nous trouvons qu'il y faille courir. Car il y a danger que nous fantasions des offices nouveaux pour excuser nostre negligence envers les naturels offices et pour les confondre. Qu'il soit ainsin : il se void qu'és lieus où les fautes sont malefices, les malefices ne sont que fautes; qu'és nations où les loix de la bienseance sont plus rares et laches, les loix primitives et communes sont mieux observées, l'innumerable multitude de tant de devoirs suffoquant nostre soin, l'alanguissant et dissipant. L'application aux menues choses nous retire des pressantes. O que ces hommes superficiels prennent une routte facile et plausible au pris de la nostre. Ce sont ombrages de quoy nous nous plastrons et entrepayons; mais nous n'en payons pas, ainçois en rechargeons nostre debte envers ce grand juge qui trousse nos panneaus et haillons d'autour noz parties honteuses, et ne se feint point à nous veoir par tout, jusques à noz intimes et plus secretes ordures. Utile decence de nostre virginale pudeur, si elle luy pouvoit interdire cette descouverte. En fin qui desniaiseroit I'homme d'une si scrupuleuse superstition verbale n'apporteroit pas grande perte au monde. Nostre vie est partie en folie, partie en prudence. Qui n'en escrit que reveremment et regulierement, il en laisse en arriere plus de la moitié. Je ne m'excuse pas envers moy; et, si je le faisoy, ce seroit plustost de mes excuses que je m'excuseroy que de nulle 
autre partie. Je m'excuse à certaines humeurs, que je tiens plus fortes en nombre que celles qui sont de mon costé. En leur consideration, je diray encores cecy (car je desire de contenter chacun, chose pourtant tres difficile, esse unum hominem accommodatum ad tantam morum ac sermonum et volontatum varietatem), qu'ils n'ont à se prendre proprement à moy de ce que je fay dire aux auctoritez receues et approuvées de plusieurs siecles, et que ce n'est pas raison qu'à faute de rime ils me refusent la dispense que mesme des hommes ecclesiastiques des nostres et plus crestez jouissent en ce siecle. En voici deux : Rimula, dispeream, ni monogramma tua est. Un vit d'amy la contente et bien traicte. Quoy tant d'autres? J'ayme la modestie ; et n'est par jugement que j'ay choisi cette sorte de parler scandaleux: c'est Nature qui l'a choisi pour moy. Je ne le loue, non plus que toutes formes contraires à l'usage reçeu; mais je l'excuse et par particulieres et generales circonstances en allege l'accusation. [...]

(III, 8, “De l'Art de Conferer")

Interessa na íntegra à discussão da suffisance.

\section{(III, 9, “De la vanité”, p. 962-65; p. 994-96.)}

[...] Encores en ces ravasseries icy crains-je la trahison de ma memoire, que par inadvertance elle m'aye faict enregistrer une chose deux fois. Je hay à me reconnoistre, et ne retaste jamais qu'envis ce qui m'est une fois eschappé. Or je n'apporte icy rien de nouvel apprentissage. Ce sont imaginations communes : les ayant à l'avanture conceues cent fois, j'ay peur de les avoir desjà enrollées. La redicte est par tout ennuyeuse, fut ce dans Homere, mais elle est ruineuse aux choses qui n'ont qu'une montre superficielle et passagiere. Je me desplais de l'inculcation, voire aux choses utiles, comme en Seneque, et l'usage de son escole stoïque me desplait, de redire sur chaque matiere tout au long et au large les principes et presuppositions qui servent en general, et realleguer tousjours de nouveau les argumens et raisons communes et universelles. Ma memoire s'empire cruellement tous les jours,

\section{Pocula Lethaeos ut si ducentia somnos}

\section{Arente fauce traxerim.}

II faudra doresnavant, car Dieu mercy jusques à cette heure il n'en est pas advenu de faute, que, au lieu que les autres cerchent temps et occasion de penser à ce qu'ils ont à dire, je fuye à me preparer, de peur de m'attacher à quelque obligation de laquelle j'aye à despendre. L'estre tenu et obligé me fourvoie, et le despendre d'un si foible instrument qu'est ma memoire. Je ne lis jamais cette histoire que je ne m'en offence, d'un ressentiment propre et naturel: Lyncestez, accusé de conjuration contre Alexandre, le jour qu'il fut mené en la presence de l'armée, suyvant la coustume, pour estre ouy en ses deffences, avoit en sa teste une harangue estudiée, de laquelle tout hesitant et begayant il prononça quelques paroles. Comme il se troubloit de plus en plus, ce pendant qu'il luicte avec sa memoire et qu'il la retaste, le voilà chargé et tué à coups de pique par les soldats qui luy estoient plus voisins, le tenant pour convaincu. Son estonnement et son silence leur servit de confession: ayant eu en prison tant de loisir de se preparer, ce n'est à leur advis plus la memoire qui luy manque, c'est la conscience qui luy bride la langue et luy oste la force. Vrayment c'est bien dict ! Le lieu estonne, l'assistance, l'expectation, lors mesme qu'il n'y va que de l'ambition de bien dire. Que peut-on faire quand c'est une harangue qui porte la vie en consequence? Pour moy, cela mesme que je sois lié à ce que j'ay à dire sert à m'en desprendre. Quand je me suis commis et assigné entierement à ma memoire, je pends si fort sur elle que je l'accable: elle s'effraye de sa charge. Autant que je m'en rapporte à elle, je me mets hors de moy, jusques à essaier ma contenance; et me suis veu quelque jour en peine de celer la 
servitude en laquelle j'estois entravé, là où mon dessein est de representer en parlant une profonde nonchalance et des mouvemens fortuites et impremeditez, comme naissans des occasions presentes; aymant aussi cher ne rien dire qui vaille que de montrer estre venu preparé pour bien dire, chose messeante, sur tout à gens de ma profession, et chose de trop grande obligation à qui ne peut beaucoup tenir: l'apprest donne plus à esperer qu'il ne porte. On se met souvent sottement en pourpoinct pour ne sauter pas mieux qu'en saye. Nihil est his qui placere volunt tam adversarium quam expectatio. Ils ont laissé par escrit de l'orateur Curio que, quand il proposoit la distribution des pieces de son oraison en trois ou en quatre ou le nombre de ses arguments et raisons, il luy advenoit volontiers, ou d'en oublier quelqu'un, ou d'y en adjouster un ou deux de plus. Je me suis tousjours bien gardé de tomber en cet inconvenient, ayant hay ces promesses et prescriptions: non seulement pour la deffiance de ma memoire, mais aussi pour ce que cette forme retire trop à l'artiste. Simpliciora militare decent. Baste que je me suis meshuy promis de ne prendre plus la charge de parler en lieu de respect. Car quant à parler en lisant son escript, outre ce qu'il est monstrueux, il est de grand desavantage à ceux qui par nature pouvoient quelque chose en l'action. Et de me jetter à la mercy de mon invention presente, encore moins: je l'ay lourde et trouble, qui ne sçauroit fournir à soudaines necessitez, et importantes. Laisse, lecteur, courir encore ce coup d'essay et ce troisiesme allongeail du reste des pieces de ma peinture. J'adjouste, mais je ne corrige pas. Premierement, par ce que celuy qui a hypothecqué au monde son ouvrage, je trouve apparence qu'il n'y aye plus de droict. Qu'il die, s'il peut, mieux ailleurs, et ne corrompe la besongne qu'il a vendue. De telles gens il ne faudroit rien acheter qu'apres leur mort. Qu'ils y pensent bien avant que de se produire. Qui les haste? Mon livre est tousjours un. Sauf qu'à mesure qu'on se met à le renouveller, afin que l'acheteur ne s'en aille les mains du tout vuides, je me donne loy d'y attacher (comme ce n'est qu'une marqueterie mal jointe), quelque embleme supernumeraire. Ce ne sont que surpoids, qui ne condamnent point la premiere forme, mais donnent quelque pris particulier à chacune des suivantes par une petite subtilité ambitieuse. De là toutesfois il adviendra facilement qu'il s'y mesle quelque transposition de chronologie, mes contes prenans place selon leur opportunité, non tousjours selon leur aage. Secondement que, pour mon regard, je crains de perdre au change: mon entendement ne va pas tousjours avant, il va à reculons aussi. Je ne me deffie guiere moins de mes fantasies pour estre secondes ou tierces que premieres, ou presentes que passées. Nous nous corrigeons aussi sottement souvent comme nous corrigeons les autres. Mes premieres publications furent l'an mille cinq cens quatre vingts. Depuis d'un long traict de temps je suis envieilli, mais assagi je ne le suis certes pas d'un pouce. Moy à cette heure et moy tantost sommes bien deux; mais quand meilleur, je n'en puis rien dire. II feroit beau estre vieil si nous ne marchions que vers l'amendement. C'est un mouvement d'yvroigne titubant, vertigineux, informe, ou des joncs que l'air manie casuellement selon soy. Antiochus avoit vigoureusement escrit en faveur de l'Academie; il print sur ses vieux ans un autre party. Lequel des deux je suyvisse, seroit pas tousjours suivre Antiochus? Apres avoir establi le doubte, vouloir establir la certitude des opinions humaines estoit ce pas establir le doubte, non la certitude, et promettre qui luy eust donné encore un aage à durer qu'il estoit tousjours en terme de nouvelle agitation, non tant meilleure qu'autre? La faveur publique m'a donné un peu plus de hardiesse que je n'esperois, mais ce que je crains le plus, c'est de saouler: j'aymerois mieux poindre que lasser, comme a faict un sçavant homme de mon temps. La louange est tousjours plaisante, de qui et pourquoy elle vienne: si faut il, pour s'en aggréer justement, estre informé de sa cause. Les imperfections mesme ont leur moyen de se recommander. L'estimation vulgaire et commune se voit peu heureuse en rencontre; et, de mon temps, je suis trompé si les pires escrits ne sont ceux qui ont 
gaigné le dessus du vent populaire. Certes je rends graces à des honnestes hommes qui daignent prendre en bonne part mes foibles efforts. II n'est lieu où les fautes de la façon paroissent tant qu'en une matiere qui de soy n'a point de recommendation. Ne te prens point à moy, Lecteur, de celles qui se coulent icy par la fantasie ou inadvertance d'autruy: chaque main, chaque ouvrier y apporte les siennes. Je ne me mesle ny d'ortografe, et ordonne seulement qu'ils suivent l'ancienne, ny de la punctuation; je suis peu expert en l'un et en l'autre. Où ils rompent du tout le sens, je m'en donne peu de peine, car au-moins ils me deschargent; mais où ils en substituent un faux, comme ils font si souvent, et me destournent à leur conception, ils me ruynent. Toutesfois, quand la sentence n'est forte à ma mesure, un honeste homme la doit refuser pour mienne. Qui connoistra combien je suis peu laborieux, combien je suis faict à ma mode, croira facilement que je redicterois plus volontiers encore autant d'essais que de m'assujettir à resuivre ceux-cy, pour cette puerile correction. Je disois donc tantost, qu'estant planté en la plus profonde miniere ...

[...] Cette farcisseure est un peu hors de mon theme. Je m'esgare, mais plustot par licence que par mesgarde. Mes fantasies se suyvent, mais par fois c'est de loing, et se regardent, mais d'une veue oblique. J'ay passé les yeux sur tel dialogue de Platon mi party d'une fantastique bigarrure, le devant à l'amour, tout le bas à la rhetorique. Ils ne creignent point ces muances, et ont une merveilleuse grace à se laisser ainsi rouler au vent, ou à le sembler. Les noms de mes chapitres n'en embrassent pas tousjours la matiere; souvent ils la denotent seulement par quelque marque, comme ces autres tiltres : l'Andrie, l'Eunuche, ou ces autres noms : Sylla, Cicero, Torquatus. J'ayme l'alleure poetique, à sauts et à gambades. C'est une art, comme dict Platon, legere, volage, demoniacle. II est des ouvrages en Plutarque où il oublie son theme, où le propos de son argument ne se trouve que par incident, tout estouffé en matiere estrangere: voyez ses alleures au Daemon de Socrates. O Dieu, que ces gaillardes escapades, que cette variation a de beauté, et plus lors que plus elle retire au nonchalant et fortuite. C'est l'indiligent lecteur qui pert mon subject, non pas moy; il s'en trouvera tousjours en un coing quelque mot qui ne laisse pas d'estre bastant, quoy qu'il soit serré. Je vois au change, indiscrettement et tumultuairement. Mon stile et mon esprit vont vagabondant de mesmes. II faut avoir un peu de folie qui ne veut avoir plus de sottise, disent et les preceptes de nos maistres et encores plus leurs exemples. Mille poetes trainent et languissent à la prosaïque; mais la meilleure prose ancienne (et je la seme ceans indifferemment pour vers) reluit par tout de la vigueur et hardiesse poetique, et represente l'air de sa fureur. II luy faut certes quitter la maistrise et preeminence en la parlerie. Le poete, dict Platon, assis sur le trepied des Muses, verse de furie tout ce qui luy vient en la bouche, comme la gargouille d'une fontaine, sans le ruminer et poiser, et luy eschappe des choses de diverse couleur, de contraire substance et d'un cours rompu. Luy mesmes est tout poetique, et la vieille theologie poesie, disent les sçavants, et la premiere philosophie. C'est l'originel langage des Dieux. J'entends que la matiere se distingue soy-mesmes. Elle montre assez où elle se change, où elle conclud, où elle commence, où elle se reprend, sans l'entrelasser de paroles, de liaison et de cousture introduictes pour le service des oreilles foibles ou nonchallantes, et sans me gloser moymesme. Qui est celuy qui n'ayme mieux n'estre pas leu que de l'estre en dormant ou en fuyant? Nihil est tam utile, quod in transitu prosit. Si prendre des livres estoit les apprendre, et si les veoir estoit les regarder, et les parcourir les saisir, j'aurois tort de me faire du tout si ignorant que je dy. Puisque je ne puis arrester l'attention du lecteur par le pois, manco male s'il advient que je l'arreste par 
mon embrouilleure.--Voire, mais il se repentira par apres de s'y estre amusé.--C'est mon, mais il s'y sera tousjours amusé. Et puis il est des humeurs comme cela, à qui l'intelligence porte desdain, qui m'en estimeront mieux de ce qu'ils ne sçauront ce que je dis: ils conclurront la profondeur de mon sens par l'obscurité, laquelle, à parler en bon escient, je hay bien fort, et l'eviterois si je me sçavois eviter. Aristote se vante en quelque lieu de l'affecter; vitieuse affectation. Par ce que la coupure si frequente des chapitres, de quoy j'usoy au commencement, m'a semblé rompre l'attention avant qu'elle soit née, et la dissoudre, dedeignant s'y coucher pour si peu et se recueillir, je me suis mis à les faire plus longs, qui requierent de la proposition et du loisir assigné. En telle occupation, à qui on ne veut donner une seule heure on ne veut rien donner. Et ne faict on rien pour celuy pour qui on ne faict qu'autre chose faisant. Joint qu'à l'adventure ay-je quelque obligation particuliere à ne dire qu'à demy, à dire confusément, à dire discordamment. J'avois à dire que je veus mal à cette raison trouble-feste, et que ces projects extravagants qui travaillent la vie, et ces opinions si fines, si elles ont de la verité, je la trouve trop chere et incommode. Au rebours, je m'emploie à faire valoir la vanité mesme et l'asnerie si elle m'apporte du plaisir, et me laisse aller apres mes inclinations naturelles sans les contreroller de si pres. [...]

\section{(III, 12, “De la phisionomie”, p. 1055-57.)}

Comme quelqu'un pourroit dire de moy que j'ay seulement faict icy un amas de fleurs estrangeres, n'y ayant fourny du mien que le filet à les lier. Certes j'ay donné à l'opinion publique que ces parements empruntez m'accompaignent. Mais je n'entends pas qu'ils me couvrent, et qu'ils me cachent: c'est le rebours de mon dessein, qui ne veux faire montre que du mien, et de ce qui est mien par nature; et si je m'en fusse creu, à tout hazard, j'eusse parlé tout fin seul. Je m'en charge de plus fort tous les jours outre ma proposition et ma forme premiere, sur la fantasie du siecle et enhortemens d'autruy. S'il me messied à moy, comme je le croy, n'importe: il peut estre utile à quelque autre. Tel allegue Platon et Homere, qui ne les veid onques. Et moy ay prins des lieux assez ailleurs qu'en leur source. Sans peine et sans suffisance, ayant mille volumes de livres autour de moy en ce lieu où j'escris, j'emprunteray presentement s'il me plaist d'une douzaine de tels ravaudeurs, gens que je ne feuillette guiere, de quoy esmailler le traicté de la phisionomie. II ne faut que l'espitre liminaire d'un alemand pour me farcir d'allegations; et nous allons quester par là une friande gloire, à piper le sot monde. Ces pastissages de lieux communs, dequoy tant de gents mesnagent leur estude, ne servent guere qu'à subjects communs; et servent à nous montrer non à nous conduire, ridicule fruict de la science, que Socrates exagite si plaisamment contre Euthydeme. J'ay veu faire des livres de choses ny jamais estudiées ny entendues, l'autheur commettant à divers de ses amis sçavants la recherche de cette-cy et de cette autre matiere à le bastir, se contentant pour sa part d'en avoir projetté le dessein et empilé par son industrie ce fagot de provisions incogneues; au moins est sien l'ancre et le papier. Cela c'est en conscience achetter ou emprunter un livre, non pas le faire. C'est apprendre aux hommes, non qu'on sçait faire un livre, mais, ce dequoy ils pouvoient estre en doute, qu'on ne le sçait pas faire. Un president se vantoit, où j'estois, d'avoir amoncelé deux cens tant de lieux estrangers en un sien arrest presidental. En le preschant à chacun il me sembla effacer la gloire qu'on luy en donnoit. Pusillanime et absurde vanterie à mon gré pour un tel subject et telle personne. Parmy tant d'emprunts je suis bien aise d'en pouvoir desrober quelqu'un, les desguisant et difformant à nouveau service. Au hazard que je laisse dire que c'est par faute d'avoir entendu leur naturel usage, je luy donne quelque particuliere adresse de ma main à ce qu'ils en soient d'autant moins purement 
estrangers. Ceux-cy mettent leurs larrecins en parade et en conte: aussi ont ils plus de crédit aux loix que moy. Nous autres naturalistes estimons qu'il y aie grande et incomparable preferance de l'honneur de l'invention à l'honneur de l'allegation. Si j'eusse voulu parler par science, j'eusse parlé plus-tost: j'eusse escript du temps plus voisin de mes estudes, que j'avois d'esprit et de memoire; et me fusse plus fié à la vigueur de cet aage là qu'a cettuy-icy, si j'en eusse voulu faire mestier d'escrire. Davantage, telle faveur gratieuse que la fortune peut m'avoir offerte par l'entremise de cet ouvrage eust lors rencontré une plus propice saison. Deux de mes cognoissans, grands hommes en cette faculté, ont perdu par moitié, à mon advis, d'avoir refusé de se mettre au jour à quarante ans, pour attendre les soixante. La maturité a ses deffauts, comme la verdeur, et pires. Et autant est la vieillesse incommode à cette nature de besongne qu'à toute autre. Quiconque met sa decrepitude soubs la presse faict folie, s'il espere en espreindre des humeurs qui ne sentent le disgratié, le resveur et l'assopi. Nostre esprit se constipe et se croupit en vieillissant. Je dis pompeusement et opulemment l'ignorance, et dys la science megrement et piteusement; accessoirement cette-cy et accidentalement, celle là expressément et principalement. Et ne traicte à point nommé de rien que du rien, ny d'aucune science que de celle de l'inscience. J'ay choisi le temps où ma vie, que j'ay à peindre, je l'ay toute devant moy: ce qui en reste tient plus de la mort. Et de ma mort seulement, si je la rencontrois babillarde, comme font d'autres, donrrois je encore volontiers advis au peuple en deslogeant.

\section{(III, 13, “De l'experience”, p. 1072-79.)}

Quel que soit donq le fruict que nous pouvons avoir de l'experience, à peine servira beaucoup à nostre institution celle que nous tirons des exemples estrangers, si nous faisons si mal nostre proffict de celle que nous avons de nous mesme, qui nous est plus familiere, et certes suffisante à nous instruire de ce qu'il nous faut. Je m'estudie plus qu'autre subject. C'est ma metaphisique, c'est ma phisique.

\section{Qua Deus hanc mundi temperet arte domum, Qua venit exoriens, qua deficit, unde coactis Cornibus in plenum menstrua luna redit; \\ Unde salo superant venti, quid flamine captet Eurus, et in nubes unde perennis aqua.}

\section{Sit ventura dies mundi quae subruat arces.}

Quaerite quos agitat mundi labor. En ceste université, je me laisse ignoramment et negligemment manier à la loy generale du monde. Je la sçauray assez quand je la sentiray. Ma science ne luy sçauroit faire changer de route; elle ne se diversifiera pas pour moi. C'est folie de l'esperer, et plus grand folie de s'en mettre en peine, puis qu'elle est necessairement semblable, publique et commune. La bonté et capacité du gouverneur nous doit à pur et à plein descharger du soing de son gouvernement. Les inquisitions et contemplations philosophiques ne servent que d'aliment à nostre curiosité. Les philosophes, avec grand raison, nous renvoyent aux regles de Nature; mais elles n'ont que faire de si sublime cognoissance: ils les falsifient et nous presentent son visage peint trop haut en couleur et trop sophistiqué, d'où naissent tant de divers pourtraits d'un subject si uniforme. Comme elle nous a fourni de pieds à marcher, aussi a elle de prudence à nous guider en la vie; prudence, non tant ingenieuse, robuste et 
pompeuse comme celle de leur invention, mais à l'advenant facile et salutaire, et qui faict tres-bien ce que l'autre dict, en celuy qui a l'heur de sçavoir s'employer naïvement et ordonnéement, c'est à dire naturellement. Le plus simplement se commettre à nature, c'est s'y commettre le plus sagement. $O$ que c'est un doux et mol chevet, et sain, que l'ignorance et l'incuriosité, à reposer une teste bien faicte. J'aymerois mieux m'entendre bien en moy qu'en Ciceron. De l'experience que j'ay de moy, je trouve assez dequoy me faire sage, si j'estoy bon escholier. Qui remet en sa memoire l'excez de sa cholere passée, et jusques où cette fiévre l'emporta, voit la laideur de cette passion mieux que dans Aristote, et en conçoit une haine plus juste. Qui se souvient des maux qu'il a couru, de ceux qui l'ont menassé, des legeres occasions qui l'ont remué d'un estat à autre, se prepare par là aux mutations futures et à la recognoissance de sa condition. La vie de Caesar n'a poinct plus d'exemple que la nostre pour nous; et emperière, et populaire, c'est tousjours une vie que tous accidents humains regardent. Escoutons y seulement : nous nous disons tout ce de quoy nous avons principalement besoing. Qui se souvient de s'estre tant et tant de fois mesconté de son propre jugement, est-il pas un sot de n'en entrer pour jamais en deffiance? Quand je me trouve convaincu par la raison d'autruy d'une opinion fauce, je n'apprens pas tant ce qu'il m'a dict de nouveau et cette ignorance particuliere (ce seroit peu d'acquest), comme en general j'apprens ma debilité et la trahison de mon entendement; d'où je tire la reformation de toute la masse. En toutes mes autres erreurs je faits de mesme, et sens de cette reigle grande utilité à la vie. Je ne regarde pas l'espece et l'individu comme une pierre où j'aye bronché; j'apprens à craindre mon alleure par tout, et m'attens à la reigler. D'apprendre qu'on a dict ou faict une sottise, ce n'est rien que cela; il faut apprendre qu'on n'est qu'un sot, instruction bien plus ample et importante. Les faux pas que ma memoire m'a fait si souvant, lors mesme qu'elle m'asseure le plus de soy, ne se sont pas inutilement perduz: elle a beau me jurer à cette heure et m'asseurer, je secoue les oreilles; la premiere opposition qu'on faict à son tesmoignage me met en suspens, et n'oserois me fier d'elle en chose de poix, ny la garentir sur le faict d'autruy. Et n'estoit que ce que je fay par faute de memoire, les autres le font encore plus souvant par faute de foy, je prendrois tousjours en chose de faict la verité de la bouche d'un autre plustost que de la mienne. Si chacun espioit de pres les effects et circonstances des passions qui le regentent, comme j'ay faict de celle à qui j'estois tombé en partage, il les verroit venir, et ralantiroit un peu leur impetuosité et leur course. Elles ne nous sautent pas tousjours au colet d'un prinsaut; il y a de la menasse et des degretz.

\section{Fluctus uti primo coepit cum albescere ponto, Paulatim sese tollit mare, et altius undas \\ Erigit, inde imo consurgit ad aethera fundo.}

Le jugement tient chez moy un siege magistral, au moins il s'en efforce soingneusement; il laisse mes appetis aller leur trein, et la haine et l'amitié, voire et celle que je me porte à moy-mesme, sans s'en alterer et corrompre. S'il ne peut reformer les autres parties selon soy, au moins ne se laisse il pas difformer à elles: il faict son jeu à part. L'advertissement à chacun de se cognoistre doibt estre d'un important effect, puisque ce Dieu de science et de lumiere le fit planter au front de son temple, comme comprenant tout ce qu'il avoit à nous conseiller. Platon dict aussi que prudence n'est autre chose que l'execution de cette ordonnance, et Socrates le verifie par le menu en Xenophon. Les difficultez et l'obscurité ne s'aperçoivent en chacune science que par ceux qui y ont entrée. Car encore faut il quelque degré d'intelligence à pouvoir remarquer qu'on ignore, et faut pousser à une porte pour sçavoir qu'elle nous est close. D'où naist cette Platonique subtilité que, ny ceux qui sçavent n'ont à s'enquerir, d'autant qu'ils sçavent, 
ny ceux qui ne sçavent, d'autant que pour s'enquerir il faut sçavoir de quoy on s'enquiert. Ainsin en cette-cy de se cognoistre soy mesme, ce que chacun se voit si resolu et satisfaict, ce que chacun y pense estre suffisamment entendu, signifie que chacun n'y entend rien du tout, comme Socrates apprend à Euthydeme en Xenophon. Moy qui ne faicts autre profession, y trouve une profondeur et varieté si infinie, que mon apprentissage n'a autre fruict que de me faire sentir combien il me reste à apprendre. A ma foiblesse si souvant recogneue je doibts l'inclination que j'ay à la modestie, à l'obeyssance des creances qui me sont prescrites, à une constante froideur et moderation d'opinions, et la hayne à cette arrogance importune et quereleuse, se croyant et fiant toute à soy, ennemye capitale de discipline et de verité. Oyez les regenter : les premieres sotises qu'ils mettent en avant, c'est au stile qu'on establit les religions et les loix. Nil hoc est turpius quam cognitioni et perceptioni assertionem approbationemque praecurrere. Aristarchus disoit qu'anciennement à peine se trouva il sept sages au monde, et que de son temps à peine se trouvoit il sept ignorans. Aurions nous pas plus de raison que luy de le dire en nostre temps? L'affirmation et l'opiniastreté sont signes exprez de bestise. Cettuy-cy aura donné du nez à terre cent fois pour un jour: le voylà sur ses ergots, aussi resolu et entier que devant; vous diriez qu'on luy a infuz dépuis quelque nouvelle ame et vigueur d'entendement, et qu'il luy advient comme à cet ancien fils de la terre, qui reprenoit nouvelle fermeté et se renforçoit par sa cheute,

\section{cui, cum tetigere parentem, Jam defecta vigent renovato robore membra.}

Ce testu indocile pense il pas reprendre un nouvel esprit pour reprendre une nouvelle dispute? C'est par mon experience que j'accuse l'humaine ignorance, qui est, à mon advis, le plus seur party de l'escole du monde. Ceux qui ne la veulent conclurre en eux par un si vain exemple que le mien ou que le leur, qu'ils la recognoissent par Socrates, le maistre des maistres. Car le philosophe Antisthenes à ses disciples: Allons, disoit-il, vous et moy ouyr Socrates; là je seray disciple avec vous. Et, soustenant ce dogme de sa secte Stoïque, que la vertu suffisoit à rendre une vie pleinement heureuse et n'ayant besoin de chose quelconque: Sinon de la force de Socrates, adjoustoit il. Cette longue attention que j'employe à me considerer me dresse à juger aussi passablement des autres, et est peu de choses dequoy je parle plus heureusement et excusablement. II m'advient souvant de voir et distinguer plus exactement les conditions de mes amys qu'ils ne font eux mesmes. J'en ay estonné quelqu'un par la pertinence de ma description, et l'ay adverty de soy. Pour m'estre, dés mon enfance, dressé à mirer ma vie dans celle d'autruy, j'ay acquis une complexion studieuse en cela, et, quand j'y pense, je laisse eschaper au tour de moy peu de choses qui y servent : contenances, humeurs, discours. J'estudie tout : ce qu'il me faut fuyr, ce qu'il me faut suyvre. Ainsin à mes amys je descouvre, par leurs productions, leurs inclinations internes; non pour renger cette infinie varieté d'actions, si diverses et si descoupées, à certains genres et chapitres, et distribuer distinctement mes partages et divisions en classes et regions cogneues,

\section{Sed neque quam multae species, et nomina quae sint, Est numerus.}

Les sçavans partent et denotent leurs fantasies plus specifiquement, et par le menu. Moy, qui n'y voy qu'autant que l'usage m'en informe, sans regle, presante generalement les miennes, et à tastons. Comme en cecy : je prononce ma sentence par articles 
descousus, ainsi que de chose qui ne se peut dire à la fois et en bloc. La relation et la conformité ne se trouvent poinct en telles ames que les nostres, basses et communes. La sagesse est un bastiment solide et entier, dont chaque piece tient son rang et porte sa marque. Sola sapientia in se tota conversa est. Je laisse aux artistes, et ne sçay s'ils en viennent à bout en chose si meslée, si menue et fortuite, de renger en bandes cette infinie diversité de visages, et arrester nostre inconstance et la mettre par ordre. Non seulement je trouve mal-aisé d'attacher nos actions les unes aux autres, mais chacune à part soy je trouve mal-aysé de la designer proprement par quelque qualité principalle, tant elles sont doubles et bigarrées à divers lustres. Ce qu'on remarque pour rare au Roy de Macedoine Perseus, que son esprit, ne s'attachant à aucune condition, alloit errant par tout genre de vie et representant des moeurs si essorées et vagabondes qu'il n'estoit cogneu ny de luy ny d'autre quel homme ce fust, me semble à peu pres convenir à tout le monde. Et par dessus tous j'ai veu quelque autre de sa taille à qui cete conclusion s'appliqueroit plus proprement encore, ce croy-je: nulle assiette moyenne, s'emportant tousjours de l'un à l'autre extreme par occasions indivinables, nulle espece de train sans traverse et contrarieté merveilleuse, nulle faculté simple; si que, le plus vraysemblablement qu'on en pourra feindre un jour, ce sera qu'il affectoit et estudioit de se rendre cogneu par estre mescognoissable. II faict besoing des oreilles bien fortes pour s'ouyr franchement juger; et, par ce qu'il en est peu qui le puissent souffrir sans morsure, ceux qui se hazardent de l'entreprendre envers nous nous montrent un singulier effect d'amitié; car c'est aimer sainement d'entreprendre à blesser et offencer pour proffiter. Je trouve rude de juger celluy-là en qui les mauvaises qualitez surpassent les bonnes. Platon ordonne trois parties à qui veut examiner l'ame d'un autre : science, bienveillance, hardiesse. Quelque fois on me demandoit à quoy j'eusse pensé estre bon, qui se fut advisé de se servir de moy pendant que j'en avois l'aage,

\section{Dum melior vires sanguis dabat, aemula necdum}

Temporibus geminis canebat sparsa senectus.

--A rien, fis-je!. Et m'excuse volontiers de ne sçavoir faire chose qui m'esclave à autruy. Mais j'eusse dict ses veritez à mon maistre, et eusse contrerrolé ses meurs, s'il eust voulu. Non en gros, par leçons scholastiques, que je ne sçay point (et n'en vois naistre aucune vraye reformation en ceux qui les sçavent), mais les observant pas à pas, à toute oportunité, et en jugeant à l'oeil piece à piece, simplement et naturellement, luy faisant voyr quel il est en l'opinion commune, m'opposant à ses flateurs. II n'y a nul de nous qui ne valut moins que les Roys, s'il estoit ainsi continuellement corrompu, comme ils sont de cette canaille de gens. Comment, si Alexandre, ce grand et Roy et philosophe, ne s'en peut deffendre' J'eusse eu assez de fidelité, de jugement et de liberté pour cela. Ce seroit un office sans nom; autrement il perdroit son effect et sa grace. Et est un rolle qui ne peut indifferemment appartenir à tous. Car la verité mesme n'a pas ce privilege d'estre employée à toute heure et en toute sorte: son usage, tout noble qu'il est, a ses circonscriptions et limites. II advient souvant, comme le monde est, qu'on la lache à l'oreille du prince, non seulement sans fruict mais dommageablement, et encore injustement. Et ne me fera l'on pas accroire qu'une sainte remontrance ne puisse estre appliquée vitieusement, et que l'interest de la substance ne doive souvent ceder à l'interest de la forme. Je voudrois à ce mestier un homme content de sa fortune,

Quod sit esse velit, nihilque malit, 
et nay de moyenne fortune; d'autant que, d'une part, il n'auroit point de craincte de toucher vifvement et profondement le coeur du maistre pour ne perdre par là le cours de son advancement, et d'autre part, pour estre d'une condition moyenne, il auroit plus aysée communication à toute sorte de gens. Je le voudroy à un homme seul, car respandre le privilege de cette liberté et privauté à plusieurs engendreroit une nuisible irreverence. Ouy, et de celuy là je requerroy surtout la fidelité du silence. Un Roy n'est pas à croire quand il se vante de sa constance à attendre le rencontre de l'ennemy pour le service de sa gloire, si pour son proffit et amendement il ne peut souffrir la liberté des parolles d'un amy, qui n'ont autre effort que de luy pincer l'ouye, le reste de leur effect estant en sa main. Or il n'est aucune condition d'hommes qui ayt si grand besoing que ceux-là de vrays et libres advertissemens. Ils soustiennent une vie publique, et ont à agreer à l'opinion de tant de spectateurs, que, comme on a accoustumé de leur taire tout ce qui les divertit de leur route, ils se trouvent, sans le sentir, engagez en la hayne et detestation de leurs peuples pour des occasions souvent qu'ils eussent peu eviter, à nul interest de leurs plaisirs mesme, qui les en eut advisez et redressez à temps. Communement leurs favorits regardent à soy plus qu'au maistre; et il leur va de bon, d'autant qu'à la verité la plus part des offices de la vraye amitié sont envers le souverain en un rude et perilleus essay; de maniere qu'il y faict besoing non seulement beaucoup d'affection et de franchise, mais encore de courage. En fin, toute cette fricassée que je barbouille icy n'est qu'un registre des essais de ma vie, qui est, pour l'interne santé, exemplaire assez à prendre l'instruction à contre-poil. Mais quant à la santé corporelle, personne ne peut fournir d'experience plus utile que moy, qui la presente pure, nullement corrompue et alterée par art et par opination. L'experience est proprement sur son fumier au subject de la medecine [...] 


\section{REFERÊNCIAS BIBLIOGRÁFICAS}

a) edições dos Ensaios:

MontAIGNE, Michel de. Les Essais. Édition conforme aux texte de l'Examplaire de Bordeaux par P.Villey et V.-L. Saulnier. Paris: PUF-Quadrige, 1992. 3 v. . Oeuvres Complètes de Montaigne. Textes établies par A. Thibaudet. Paris: Gallimard, 1962. (Bibliothèque de la Pléiade). . Les Essais. Édition de 1595, texte établie et anoté par Jean Balsamo,

Michel Magnien e Catherine Magnien-Simonin. Paris: Gallimard, 2007. (Bibliothèque de la Pléiade).

. Os Ensaios. Edição de P. Villey e V.-L. Saulnier em tradução de Rosemary Costhek Abílio. São Paulo: Martins Fontes, 2000 e 2001. 3 v.

b) bibliografia complementar (comentadores):

b.1) estudos diretamente referidos ao tema:

Bensimon, M. "Espace, Voyage, Écriture: 'De la vanité”. In Montaigne: espace, voyage, écriture, Actes du Congrès International de Thessalonique (septembre 1992), réunis par Zoé Samaras, Paris, Honoré Champion, 1995

Croquette, B. “III-9, De la vanité”. In Étude du livre III des Essais de Montaigne. Paris: Honoré Champion, 1985.

GuerRIER, O. "L'identité et ses reflets: le chapitre 'De la vanité' ". In Quand les poètes feignent: fantasie et fiction dans Les Essais de Montaigne, Paris: Honoré Champion, 2002. 
Beaujour, Michel. Miroirs d'Encre: rhétorique de l'autoportrait. Paris: Seuil, 1980.

Bellenger, Y. "Paradoxe et ironie dans les Essais de 1580". In Jones-Davis, M.

T. (org.) Le Paradoxe au Temps de la Renaissance. Paris: Jean Touzot Librairie-Editeur, s.d., p. 9-22.

BEUGNOT, Bernard. "Un aspect de la réception critique: la citation". In Oeuvres et Critiques, 1, 1976, p. 5-19.

. "Dialogue, entretien et citation à l'époque classique". In Revue Canadienne de Littérature Comparée, 1976, p. 39-40. . "Style ou styles épistolaires?". In RHLF, 78, 1978, p. 939-57.

BruSH, Craig B. "Un autoportrait n'est pas une autobiographie". In Oeuvres et Critiques. Revue internationale de la reception des oeuvres littéraires de langue française, VIII, 1-2, 1983.

BURT, E. S. "Poetic Conceit: the self-portrait and mirrors of ink". In BLum, Harold. Michel de Montaigne's Essays. New York: Chelsea House Publ., 1987.

CAVE, Terence. The cornucopian text: problems of writing in the French Renaissance. Oxford: Clarendon Press, 1979.

Coleman, Dorothy. Montaigne, quelques anciens et l'écriture des Essais. Honoré Champion, 1995. . "Montaigne's text: Negligentia Diligens". In Cambridge Procedings of the Cambridge Montaigne's Colloquium, 7-9 april 1988. 
DéfauX, G. "Rhétorique et représentation dans les Essais: de la peinture de l'autre à la peinture du moi". In Rhétorique de Montaigne - Bulletin de la Société des Amis de Montaigne (BSAM), 7ème. série, 1-2, 1985, p. 21-48.

Demers, Jeanne. "Les Essais, anti-rhétorique ou nouvelle rhétorique?". In Montaigne et la Grèce, Actes du colloque de Calamata et de Messéne, presentés par K. Christodoulou. Paris, Aux Amateurs de Livres, 1990.

DuBois, Cl.-G. "L'approfondissement de la réflexion sur l'art d'écrire dans les Essais de 1588". In Revue D'Histoire Littéraire de la France. 88ème année, no. 5. Sept-oct. Paris: Armand Colin, 1988.

Ehrulch, Hélène-Hedy. Montaigne, la conscience et le language. Paris: Kliencksieck, 1972.

FumARoLI, Marc. "Montaigne et l'éloquence du for intérieur". In Les formes brèves de la prose et le discours discontinu (XVle-XVIle siècle). Paris: Vrin, 1984.

GaravinI, Fausta. Mostri e chimere. Montaigne, il texto e il fantasma. Milano: II Mulino, 1997. . "Au sujet de Montaigne: de la Leçon à l'écriture du moi". In Carrefour Montaigne: Quaderni del Seminario di Filologia Francese, n. 2. Éd. par J. Brody et alii. Pisa, Genève: Edizioni ETS, Slatkine, 1994.

GraY, Floyd. Le style de Montaigne. Paris: Nizet, 1958.

GUERRIER, Olivier. "L'interne jurisdiction: l'essai comme exercice". In Bulletin de la Société des Amis de Montaigne. 8ème. série. no. 29-30. Paris: Librairie Honoré Champion, 2003. p. 43-59. 
Kritzman, L. D. "Montaigne et la Nouvelle Rhétorique". In Destruction/Découverte. Paris: French Forum, 1980.

La Charité, Raymond. The concept of judgment in Montaigne. La Haye: Nijhoff, 1968.

Lestringant, Frank (éd.). Rhétorique de Montaigne. Paris: Honoré Champion,1985.

Mathieu-Castellani, G. Montaigne: l'écriture de l'Essai. Paris: PUF, 1988.

MCKINLEY, M. B. "La présence du Ciceronianus dans De la vanité". In Montaigne et la rhétorique, Actes du Colloque de St. Andrews, réunis par J. O’Brien, M. Quainton et J. J. Supple, Paris: Honoré Champion, 1995.

"La bulle de la vanité". In Les terrains vagues des Essais: itinéraires et intertexte. Paris: Honoré Champion, 1996.

NAKAM, Géralde. Montaigne, la manière et la matière. Paris: Kliencksieck, 1992.

O’Brien, John. Montaigne et la Rhétorique. Paris: Honoré Champion Nouvelles, 1995.

Rıgolot, F. Le texte à la Renaissance: Des Rhétoriqueurs à Montaigne. Genève: Droz, 1982.

TÉTEL, Marcel. Stefano Guazzo: de deux conversations. In TÉTEL, Marcel. Présences italiennes dans Les Essais de Montaigne. Paris: Librairie Honoré Champion, 1992. p. 11-29.

Tournon, André. “L’Essai: un témoignage en suspens”. In Carrefour Montaigne: Quaderni del Seminario di Filologia Francese, n. 2. Éd. par J. Brody et alii. Pisa, Genève: Edizioni ETS, Slatkine, 1994. 
ThweATt, Vivian. "L'art de conférer: Art des Essais, art de vivre". In Romanic Review, 68. New York: Columbia University Press, 1977.

b.2) estudos sobre os Ensaios:

Auerbach, Erich. “L'Humaine Condition”. In: Mimesis: a representação da realidade na literatura ocidental. $4^{\underline{a}}$ ed. São Paulo: Perspectiva, 2001, p. 249-76. (Col. Estudos).

Bignotto, N. "Montaigne renascentista". In Kriterion, n. 86, Belo Horizonte, UFMG/FAFICH, 1992.

BirchaL, Telma de S. O eu nos Ensaios de Montaigne. Belo Horizonte: UFMG, 2007.

Cardoso, Sérgio. "O homem, um homem: do humanismo renascentista a Michel de Montaigne". In Perturbador Mundo Novo. São Paulo, Escuta, 1992.

- "Villey e Starobinski: duas interpretações exemplares sobre a gênese dos Ensaios". In Kriterion, vol. 23, n. 86, ago/set, 1992.

. "Uma fé, um rei, uma lei: a crise da razão política na França das Guerras de Religião". In A Crise da Razão. São Paulo: Companhia das Letras/Funarte, 1996.

. "Antigos, modernos e novos mundos da reflexão política". In Novaes, A. (org.). A invenção do Estado Nação. São Paulo: Companhia das Letras, no prelo. 
. "Paixão da igualdade, paixão da liberdade: a amizade em Montaigne".

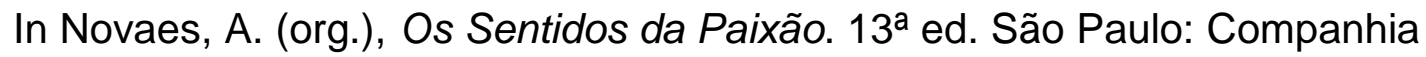
das Letras/Funarte, 2006.

. "Montaigne: uma ética para além do humanismo". In O que nos faz pensar, n. 26, no prelo.

Eva, Luiz A. Alves. Ceticismo e Paradoxo nos Ensaios de Montaigne. Tese (Doutoramento). FFLCH-USP, 1999.

. "A vaidade de Montaigne". In Discurso, n. 23. São Paulo: Discurso Editorial, 1994. p. 25-52.

. "Montaigne e o ceticismo na Apologia de Raimond Sebond: a natureza

dialética da crítica à vaidade". In O que nos faz pensar, n. 8, nov, 1994. p. 106-117.

A figura do filósofo: Ceticismo e subjetividade em Montaigne. São Paulo: Loyola, 2007.

Friedrich, Hugo. Montaigne. Traduit de l'allemand par R. Rovini. Paris: Gallimard, 1968.

Fumarolı, Marc. L'âge de l'éloquence. Paris, Genebra: Droz, 1980.

LeOPoldo e Silva, F. "A referência a Montaigne na concepção pascaliana de história". In Kriterion, no. 86. Belo Horizonte: UFMG/FAFICH, 1992.

Pedroso, Sandra P. de T. Ensaios de Montaigne: o jugement e sua forma. Dissertação (Mestrado). FFLCH-USP. 2009.

Poullloux, Jean-Yves. Montaigne: L'éveil de la pensée. Paris: Honoré Champion, 1995. 
RendalL, E. Distinguo: Reading Montaigne differently. Oxford: Clarendon Press, 1992.

Scoralick, A. Experiência e Moralidade no último dos Ensaios de Montaigne. Dissertação (Mestrado). FFLCH-USP. 2008.

SeVE, Bernard. Montaigne: Des règles pour l'esprit. Paris: PUF, 2007.

SmıтH, P. J. "Continuar e conservar: Montaigne e o poder". In História: questões e debates (Depto. História UFPR), ano XIII, n. 25, jul-dez, 1996. p. 58-81.

StARobinskI, Jean. Montaigne em Movimento. São Paulo: Cia das Letras, 1993.

Ramos, Silvana De S. Análise do capítulo De l'art de conferer (Essais III, VIII), de Michel de Montaigne. Dissertação (Mestrado). FFLCH-USP. 2004.

TheObALDo, M. C. Sobre o "Da educação das crianças": a nova maneira de Montaigne. Tese (Doutoramento). FFLCH-USP. 2008.

Tournon, André. Montaigne: la glose et l'essai. Paris: Honoré Champion, 2000. . Montaigne en toutes lettres. Paris: Bordas, 1993.

VilLey, Pierre. Les sources et l'évolution des Essais de Montaigne. Osnabrück: Otto Zeller, 1976.

b.3) obras coletivas:

ARGOd-DutARD, Françoise (org.). Des Signes au Sens: lectures du livre III des Essais. Journées d'études du centre Montaigne de Bordeaux. 14-15 novembre 2002. Paris: Librairie Honoré Champion, 2003 
Berven, Dikka (ed.). Montaigne - A Collection of Essays: a five-volume anthology of scholarly articles. New York, London: Garland Publishing, 1995.

BLum, Claude (org.). Montaigne et Les Essais (1588-1988): Actes du congrès de Paris (janvier 1988). Paris: Librairie Honoré Champion, 1990. p. 41-55.

Brody, J. et alii. Carrefour Montaigne: Quaderni del Seminario di Filologia Francese, n. 2. Pisa, Genève: Edizioni ETS, Slatkine, 1994.

FoRD, Philip; JonDORF, Gillian (ed.). Montaigne in Cambridge: procedings of the Cambridge Montaigne's colloquium, 7-9 april 1988. Cambridge: Cambridge French Colloquia, 1989.

Cameron, Keith; WiLlet, Laura (org.). Le visage changeant de Montaigne. Paris: Librairie Honoré Champion, 2003.

Charpentier, Françoise (org.) Montaigne: Les derniers essais. Actes de la journée d'étude Montaigne. Paris: UER (Sciences de Textes et Documents). Université Paris VII, 1986. (Cahiers Textuel, 34/44, no. 2). P. 19-31

DefauX, Gerard (ed.). Montaigne: Essays in Reading. Yale French Studies, number 64. New Haven: Yale University Press, 1983

Glaudes, Pierre (org.). L'essai: métamorphoses d'un genre. Paris: Presses Universitaires de Mirail, 2002. p. 135-157.

Gray, F. et TeteL, M. Textes et intertextes: études sur le XVle siècle, pour Alfred Glauser. Paris: Nizet, 1979.

Jones-Davis, M. T. (org.) Le Paradoxe au Temps de la Renaissance. Paris: Jean Touzot Librairie-Editeur, s.d. 
Montaigne et la Rhétorique. Actes du Colloque de St. Andrews. 28-31 mars 1992. Paris: Librairie Honoré Champion, 1999. (Coll. Études Montaignistes)

ZingleR, I. Le lecteur, l'auteur et l'écrivain Montaigne (1492-1592-1992), Actes du Colloque Internationale de Haifa, avril-mai, 1992. Paris: Honoré Champion, 1993. 